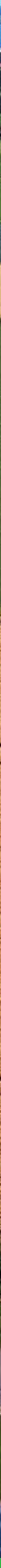

\title{
De potentie voor koolstofvastlegging in de Nederlandse landbouw
}





\section{De potentie voor koolstofvastlegging in de Nederlandse landbouw}

Jan Peter Lesschen, Chantal Hendriks, Thalisa Slier, Rima Porre, Gerard Velthof, Rene Rietra

Dit onderzoek is uitgevoerd door Wageningen Environmental Research en gesubsidieerd door het ministerie van Landbouw, Natuur en Voedselkwaliteit, in het kader van het Beleidsondersteunend onderzoekthema 'Mest, milieu en klimaat' (projectnummer BO-43-012.02-012).

Wageningen Environmental Research

Wageningen, december 2021

Gereviewd door:

Peter Kuikman, Senior Onderzoeker (Wageningen Environmental Research)

Akkoord voor publicatie:

Gert Jan Reinds, teamleider van Duurzaam Bodemgebruik

Rapport 3130

ISSN 1566-7197 
Lesschen, J.P., Hendriks, C.H., Slier, T., Porre, R.J., Velthof, G.L., Rietra, R., 2021. De potentie voor koolstofvastlegging in de Nederlandse landbouw. Wageningen, Wageningen Environmental Research, Rapport 3130. 88 blz.; 24 fig.; 11 tab.; 200 ref.

In het Nederlandse Klimaatakkoord is voor landbouwbodems een doelstelling van 0,4-0,6 Mton extra $\mathrm{CO}_{2}$-vastlegging per jaar in 2030 vastgesteld. In deze studie is de technische potentie voor koolstofvastlegging in Nederlandse landbouwbodems bepaald op basis van berekeningen met het RothC-model. De potentie voor de combinatie van maatregelen is berekend op 0,9 Mton $\mathrm{CO}_{2}$ per jaar ten opzichte van 2017. De maatregelen die het meest bijdragen, zijn meer blijvend grasland, vanggewassen/groenbemesters en het verhogen van het aandeel rustgewassen. Meer organische stof kan echter ook leiden tot een toename van $\mathrm{N}_{2} \mathrm{O}$-emissie door het toevoegen van gemakkelijk afbreekbare organische stof. Een literatuurstudie laat zien dat de meeste maatregelen een netto positief effect hebben op reductie van broeikasgasemissies, maar afhankelijk is van het huidige gewas- en bodembeheer. Voor C-vastlegging in biomassa is ook gekeken naar landschapselementen en agroforestry. Een uitbreiding van het areaal landschapselementen naar $1 \%$ van het landbouwareaal resulteert in een vastlegging van 0,4 Mton $\mathrm{CO}_{2} /$ jaar voor een periode van vijftien jaar. Het uitvoeren van het Masterplan Agroforestry (25.000 ha) resulteert in een jaarlijkse vastlegging van ongeveer 0,1 Mton $\mathrm{CO}_{2} /$ jaar.

The Dutch climate agreement comprises a target for agricultural soils to sequester an additional 0.4-0.6 Mton $\mathrm{CO}_{2}$ per year in 2030. In this study the technical potential for carbon sequestration in Dutch agricultural soils has been determined using the soil carbon model RothC at national scale. The total potential for the combination of measures is about 0,9 Mton $\mathrm{CO}_{2}$ per year compared to the baseline of 2017. More permanent grassland, cover crops and an increased share of cereals in the rotation are the measures that contribute most. More carbon in the soil can also result in an increased $\mathrm{N}_{2} \mathrm{O}$ emission due to the addition of easily decomposable organic matter. A literature study showed that most measures have a net emission reduction, but the effect depends on the current crop and soil management. This study also assessed carbon sequestration in biomass in landscape elements and agroforestry. An increase in the area of landscape elements to $1 \%$ of the agricultural area results in a sequestration rate of $0.4 \mathrm{Mton} \mathrm{CO}_{2}$ /year for a period of 15 years. For agroforestry the potential is estimated at 0.1 Mton $\mathrm{CO}_{2} /$ year if the Masterplan Agroforestry (25 000 ha) will be implemented.

Trefwoorden: koolstofvastlegging, landbouw, bodem, lachgas, landschapselementen, agroforestry

Dit rapport is gratis te downloaden van https://doi.org/10.18174/557330 of op

www.wur.nl/environmental-research (ga naar 'Wageningen Environmental Research' in de grijze balk onderaan). Wageningen Environmental Research verstrekt geen gedrukte exemplaren van rapporten.

CC license CC-BY-NC 4.0

(C) 2021 Wageningen Environmental Research (instituut binnen de rechtspersoon Stichting Wageningen Research), Postbus 47, 6700 AA Wageningen, T 03174807 00, www.wur.nl/environmental-research. Wageningen Environmental Research is onderdeel van Wageningen University \& Research.

- Overname, verveelvoudiging of openbaarmaking van deze uitgave is toegestaan mits met duidelijke bronvermelding.

- Overname, verveelvoudiging of openbaarmaking is niet toegestaan voor commerciële doeleinden en/of geldelijk gewin.

- Overname, verveelvoudiging of openbaarmaking is niet toegestaan voor die gedeelten van deze uitgave waarvan duidelijk is dat de auteursrechten liggen bij derden en/of zijn voorbehouden.

Wageningen Environmental Research aanvaardt geen aansprakelijkheid voor eventuele schade voortvloeiend uit het gebruik van de resultaten van dit onderzoek of de toepassing van de adviezen.

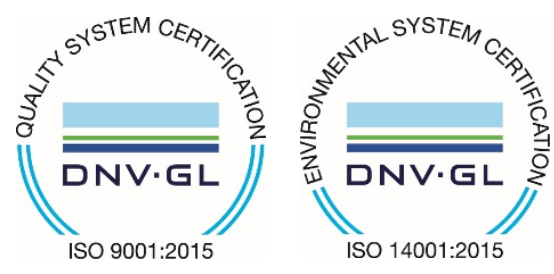

Wageningen Environmental Research werkt sinds 2003 met een ISO 9001 gecertificeerd kwaliteitsmanagementsysteem. In 2006 heeft Wageningen Environmental Research een milieuzorgsysteem geïmplementeerd, gecertificeerd volgens de norm ISO 14001.

Wageningen Environmental Research geeft via ISO 26000 invulling aan haar maatschappelijke verantwoordelijkheid.

Wageningen Environmental Research Rapport 3130 | ISSN 1566-7197

Foto omslag: Shutterstock 


\section{Inhoud}

Verantwoording $\quad 5$

$\begin{array}{ll}\text { Samenvatting } & 7\end{array}$

1

$\begin{array}{ll}\text { Inleiding } & 9\end{array}$

1.1 Beleidscontext 9

1.2 Koolstofvastlegging in landbouwbodems $\quad 10$

1.3 Koolstofvastlegging in biomassa en door steenmeel 11

$\begin{array}{lll}1.4 & \text { Doelstelling } & 11\end{array}$

1.5 Opzet van het rapport $\quad 12$

$\begin{array}{ll}\text { Beschrijving bodem-C-maatregelen } & 13\end{array}$

2.1 Verhogen aandeel rustgewassen in rotatie 13

$\begin{array}{lll}2.2 & \text { Blijvend grasland } & 14\end{array}$

$\begin{array}{ll}2.3 & \text { Aanvoer externe organische stof } \\ \end{array}$

2.3.1 Vaste mest $\quad 15$

2.3.2 Compost 16

$\begin{array}{ll}2.3 .3 \text { Bokashi } & 17\end{array}$

$\begin{array}{ll}2.3 .4 \text { Biochar } & 17\end{array}$

2.4 Vanggewassen/groenbemesters 18

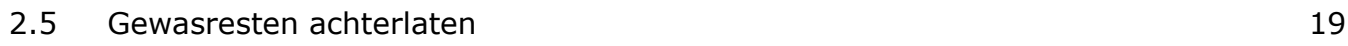

$\begin{array}{ll}2.6 & \text { Snijmais met strokenfrees }\end{array}$

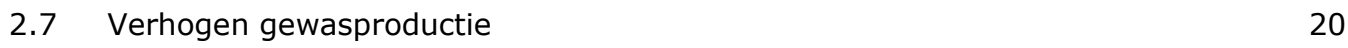

$\begin{array}{lll}2.8 & \text { Akkerranden } & 21\end{array}$

2.9 Vogelakkers $\quad 21$

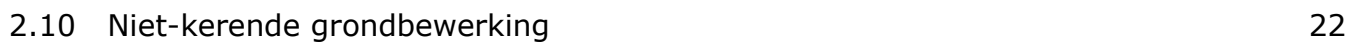

$\begin{array}{ll}2.11 \text { Kruidenrijk grasland } & 24\end{array}$

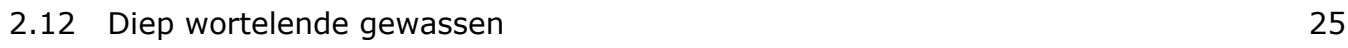

$3 \quad$ Modellering bodem-C-vastlegging $\quad 26$

$\begin{array}{lll}3.1 & \text { Methodologie } & 26\end{array}$

3.1.1 Aanpak 26

3.1.2 RothC-modelbeschrijving $\quad 26$

$\begin{array}{ll}3.1 .3 \text { Invoer data } & 27\end{array}$

$\begin{array}{lll}3.2 & \text { Baseline } & 31\end{array}$

3.3 Parametrisatie van maatregelen $\quad 32$

3.3.1 Verhogen aandeel rustgewassen in rotatie $\quad 32$

3.3.2 Verhogen aandeel blijvend grasland 33

3.3.3 Aanvoer externe organische stof $\quad 34$

3.3.4 Vanggewassen/groenbemesters $\quad 35$

$\begin{array}{ll}3.3 .5 & \text { Stro achterlaten }\end{array}$

3.3.6 Snijmais met strokenfrees $\quad 36$

3.3.7 Verhogen gewasproductie $\quad 36$

$\begin{array}{ll}3.3 .8 \text { Akkerranden } & 37\end{array}$

$\begin{array}{ll}3.3 .9 \text { Vogelakkers } & 37\end{array}$

3.4 Resultaten 38

3.4.1 Effect van maatregelen op bodemkoolstofbalans 38

$\begin{array}{ll}3.4 .2 \text { Technische potentie C-vastlegging } & 39\end{array}$

$\begin{array}{ll}3.4 .3 \text { Huidige implementatiegraad } & 40\end{array}$

3.4.4 Ruimtelijke verdeling van de potentie $\quad 41$ 
$\begin{array}{lll}4.1 & \text { Inleiding } & 46\end{array}$

$\begin{array}{lll}4.2 & \text { Aanpak } & 46\end{array}$

$\begin{array}{lll}4.3 & \text { Resultaat } & 47\end{array}$

$\begin{array}{lll}4.4 & \text { Conclusie } & 49\end{array}$

$\begin{array}{lll}5.1 & \text { Inleiding } & 50\end{array}$

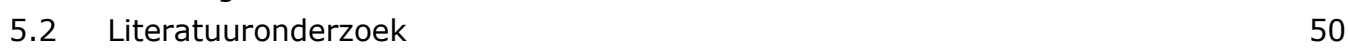

5.3 Potentie voor C-vastlegging in Nederland $\quad 51$

6.1 Inleiding 53

6.2 Processen in bodem waarbij lachgas wordt gevormd 53

6.2.1 Nitrificatie $\quad 54$

6.2.2 Biologische denitrificatie $\quad 54$

6.2.3 Chemische denitrificatie $\quad 55$

6.2.4 Nitrifier denitrification $\quad 55$

6.2.5 Bijdrage van de verschillende processen aan lachgasemissie 56

6.2.6 Omgevingsfactoren $\quad 56$

$\begin{array}{lll}6.3 & \text { Effect organische stof op lachgasemissie } & 57\end{array}$

6.3.1 Organische meststoffen $\quad 57$

$\begin{array}{ll}6.3 .2 \text { Gewasresten } & 59\end{array}$

6.3.3 Landbouwgronden $\quad 59$

6.4 Organische stof en nitraatuitspoeling $\quad 64$

$\begin{array}{lll}6.5 & \text { Synthese } & 66\end{array}$

Gebruik van steenmeel in landbouw als optie voor negatieve $\mathrm{CO}_{2}$ emissies

$\begin{array}{lll}7.1 & \text { Inleiding } & 68\end{array}$

$\begin{array}{lll}7.2 & \text { Theorie } & 68\end{array}$

$\begin{array}{lll}7.3 & \text { Mitigatie opties voor steenmeelgebruik } & 69\end{array}$

7.3.1 Optie 1. Gebruik silicaten in plaats van landbouwkalk, huidig kalkgebruik

7.3.2 Optie 2. Gebruik silicaten in plaats van landbouwkalk, waarbij kalkgift conform landbouwkundige adviezen

7.3.3 Optie 3. Gebruik van silicaten boven landbouwkundige adviezen om zoveel mogelijk $\mathrm{CO}_{2}$ te binden $\quad 71$

7.4 Conclusies

$\begin{array}{lll}\text { Bijlage } 1 & \text { Referenties figuur niet-kerende grondbewerking } & 86\end{array}$

Bijlage 2 Areaal, biomassa, C-voorraad per landschapselement (le) 87 


\section{Verantwoording}

Rapport: 3130

Projectnummer: 5200044338

Wageningen Environmental Research (WENR) hecht grote waarde aan de kwaliteit van zijn eindproducten. Een review van de rapporten op wetenschappelijke kwaliteit door een referent maakt standaard onderdeel uit van ons kwaliteitsbeleid.

Akkoord Referent die het rapport heeft beoordeeld,

functie: $\quad$ Senior onderzoeker

naam: Peter Kuikman

datum: 3 november 2021

Akkoord teamleider voor de inhoud,

naam: Gert Jan Reinds

datum: $22-11-2021$ 


\section{Samenvatting}

Met het klimaatverdrag van Parijs is de urgentie voor klimaatmitigatie hoog op de politieke en beleidsagenda gekomen. Voor landbouwbodems is in het Nederlandse Klimaatakkoord een doelstelling van 0,4-0,6 Mton extra $\mathrm{CO}_{2}$-vastlegging per jaar in 2030 vastgesteld. Er zijn verschillende maatregelen die $\mathrm{CO}_{2}$-vastlegging in Nederlandse landbouwbodem bevorderen. De doelstelling van deze studie is om inzicht te geven in de technische potentie voor koolstofvastlegging in de Nederlandse landbouwbodems. In deze nieuwe studie, een update van Lesschen et al. (2012), wordt gekeken naar meer maatregelen en wordt gebruikgemaakt van een procesmodel en de nieuwste kennis en data uit het Slim Landgebruik-programma. Daarnaast kijkt deze studie ook naar de potentie van $\mathrm{CO}_{2}$-vastlegging in biomassa in agroforestry en landschapselementen en het gebruik van steenmeel voor klimaatmitigatie. De mogelijke risico's op lachgasemissie door het nemen van bodemC-maatregelen worden ook behandeld in dit rapport. Deze resultaten dienen ter ondersteuning en onderbouwing van het huidige en toekomstige klimaatbeleid en voor kennisdoorwerking en communicatie naar de agrarische sector.

Voor het bepalen van de potentiële C-vastlegging in Nederlandse landbouwbodems, is een reeks van maatregelen die koolstofvastlegging bevorderen doorgerekend op nationale schaal. Hierbij is gebruikgemaakt van het bodem C-model RothC, een model dat de koolstofdynamiek in minerale bodems kan simuleren. Het model houdt rekening met de effecten van bodemtype, temperatuur, vochtgehalte en bodembedekking op de afbraak van organische koolstof. Voor toepassing op regionale schaal is het model ingebouwd in het MITERRA-NL model. RothC wordt gebruikt om op viercijferig postcodeniveau per gewas de koolstofbalans te bereken op basis van gegevens over bemesting, gewasopbrengst en bodem. Het basisjaar (de baseline) waarvoor de berekeningen zijn uitgevoerd, is 2017. De maatregelen zijn apart doorgerekend en worden vergeleken met deze baseline. De volgende maatregelen zijn doorgerekend: verhogen aandeel rustgewassen, verhogen aandeel blijvend grasland, extra aanvoer vaste mest en compost, toepassen van vanggewassen/groenbemesters, achterlaten van stro, snijmais met strokenfrees, akkerranden en vogelakkers. De maatregel niet-kerende grondbewerking is uiteindelijk niet meegenomen, aangezien recente literatuur en resultaten uit Slim Landgebruik laten zien dat er een herverdeling van koolstof plaatsvindt (meer in bovengrond en minder in ondergrond), maar dat het niet bijdraagt aan netto C-vastlegging.

De technische potentie voor $\mathrm{CO}_{2}$ vastlegging in landbouwbodems wordt voor de combinatie van maatregelen geschat op 0,9 Mton $\mathrm{CO}_{2}$ per jaar ten opzichte van de huidige praktijk in 2017. Dit betekent dat de doelstelling uit het Klimaatakkoord van 0,4-0,6 Mton $\mathrm{CO}_{2}$ per jaar haalbaar is. De maatregelen die het meest bijdragen, zijn maatregelen die leiden tot een extra aanvoer van gewasresten (meer blijvend grasland, vanggewassen/groenbemesters en verhogen van aandeel rustgewassen), zie Tabel S1. Dit zijn ook maatregelen die zorgen voor extra $\mathrm{C}$ in het systeem en geen/minder risico hebben op het verschuiven van koolstofstromen, wat een risico is bij de maatregelen extra vaste mest en compost. Ruimtelijk gezien ligt de hoogste potentie in de gebieden die momenteel door intensieve akkerbouw gedomineerd worden (noorden van Noord-Holland, Zeeland, Flevoland en delen van Noordoost-Groningen.

Het verhogen van het organischestofgehalte in de bodem heeft echter ook effect op de stikstofkringloop en daarmee op de emissie van het broeikasgas lachgas $\left(\mathrm{N}_{2} \mathrm{O}\right)$. Lachgas wordt gevormd tijdens de microbiële processen nitrificatie en denitrificatie in de bodem. Toediening van organische stof kan leiden tot een toename van $\mathrm{N}_{2} \mathrm{O}$-emissie doordat gemakkelijk afbreekbare organische stof een energiebron is voor denitrificerende bacteriën en afbraak van organische stof leidt tot verhoogde zuurstofconsumptie, waardoor de $\mathrm{N}_{2} \mathrm{O}$-productie bij nitrificatie en denitrificatie kan toenemen. Voor dit rapport is een literatuurstudie uitgevoerd die laat zien dat maatregelen om koolstof op te slaan een risico hebben op extra lachgasemissie, maar dat de meeste maatregelen een netto positief effect hebben op reductie van broeikasgasemissies, behalve niet-kerende grondbewerking. Het uiteindelijke effect op $\mathrm{N}_{2} \mathrm{O}$-emissies hangt ook sterk af van het huidige gewas- 
en bodembeheer; vervanging van drijfmest door een vaste mest of compost bijvoorbeeld leidt tot minder $\mathrm{N}_{2} \mathrm{O}$-emissies, terwijl vervanging van kunstmest door vaste mest mogelijk leidt tot meer $\mathrm{N}_{2} \mathrm{O}$ emissies. In het kader van het Slim Landgebruik-programma vinden nu veel $\mathrm{N}_{2} \mathrm{O}$-metingen plaats om de effecten te kwantificeren voor Nederlandse omstandigheden.

Tabel S1 Potentiële $\mathrm{CO}_{2}$-vastlegging (totaal en per ha) en additioneel areaal waarop de maatregel kan worden toegepast, uitgesplitst naar zand- en kleigrond.

\begin{tabular}{|c|c|c|c|c|c|c|}
\hline \multirow[t]{2}{*}{ Maatregelen } & \multicolumn{2}{|c|}{$\begin{array}{r}\text { Vastlegging totaal } \\
\text { (kton } \mathrm{CO}_{2} / \text { jaar) }\end{array}$} & \multicolumn{2}{|c|}{$\begin{array}{r}\text { Potentieel areaal } \\
(1000 \text { ha }) \\
\end{array}$} & \multicolumn{2}{|c|}{$\begin{array}{l}\text { Vastlegging per ha } \\
\text { (ton } \mathrm{CO}_{2} / \text { ha/jaar) }\end{array}$} \\
\hline & Zand & Klei & Zand & Klei & Zand & Klei \\
\hline Vanggewas/groenbemester & 52 & 128 & 63 & 89 & 0,83 & 1,44 \\
\hline Verhogen aandeel rustgewassen & 60 & 113 & 32 & 35 & 1,86 & 3,25 \\
\hline Extra vaste mest & 38 & 70 & 662 & 763 & 0,06 & 0,09 \\
\hline Stro achterlaten & 11 & 76 & 34 & 114 & 0,33 & 0,66 \\
\hline Snijmais met strokenfrees & 40 & 21 & 129 & 51 & 0,31 & 0,40 \\
\hline Extra compost & 21 & 32 & 293 & 387 & 0,07 & 0,08 \\
\hline Realistische combinatie van maatregelen & 428 & 459 & 662 & 763 & 0,65 & 0,60 \\
\hline
\end{tabular}

Naast C-vastlegging in landbouwbodems zijn er ook nog mogelijkheden voor C-vastlegging in biomassa. Als het areaal landschapselementen (houtwallen en elzensingels) wordt uitgebreid naar $1 \%$ van het landbouwareaal, dan resulteert dit in een extra vastlegging van 0,4 Mton $\mathrm{CO}_{2} /$ jaar. Dit vergt echter wel een behoorlijke inspanning ten opzichte van de huidige situatie met een verviervoudiging van het huidige areaal landschapselementen (van ongeveer 4000 ha naar 18000 ha). De koolstofvastlegging is wel van tijdelijke aard, aangezien de gemiddelde leeftijd zo'n 15 jaar is; na deze periode zal er ruwweg een evenwicht zijn tussen aangroei en oogst van de biomassa.

Landschapselementen dragen naast het produceren van biomassa en het vastleggen van koolstof ook bij aan de cultuurhistorische waarde van ons landschap en aan verschillende ecosysteemdiensten (bv. het stimuleren van de biodiversiteit).

Naast landschapselementen kan houtige vegetatie als agroforestry ook een integraal onderdeel worden van de landbouw. De houtige gewassen kunnen voor meerdere doeleinden worden aangeplant, zoals de productie van fruit, noten of hout. Het Masterplan Agroforestry streeft naar 25.000 ha landbouwgrond in te richten als agroforestry in 2030. Op basis van literatuuronderzoek wordt ingeschat dat realisatie van deze arealen agroforestry in 2030 resulteert in een jaarlijkse vastlegging van ongeveer $0,1 \mathrm{Mton} \mathrm{CO}_{2} /$ jaar. Naast een bijdrage aan koolstofvastlegging in de biomassa en bodem, draagt agroforestry ook bij aan de bodemkwaliteit.

Een laatste optie die in deze studie is verkend, is het gebruik van steenmeel (silicaten) ter vervanging van kalk in de landbouw. Silicaten zoals olivijn verhogen de bodem pH zoals kalk, maar bevatten geen $\mathrm{C}$ en leiden daarom niet tot $\mathrm{CO}_{2}$-emissies. De $\mathrm{CO}_{2}$-emissies van Nederland zouden bij het huidige kalkgebruik, of bij het geadviseerde gebruik van landbouwkalk, kunnen dalen met respectievelijk 0,055 en 0,12 Mton $\mathrm{CO}_{2}$ per jaar. Daarnaast is het ook een optie om veel meer silicaten te gebruiken dan landbouwkundig nodig is, om daarmee maximaal $\mathrm{CO}_{2}$ vast te leggen. Schattingen van het potentiële effect lopen sterk uiteen en grootschalige toepassing lijkt vanwege de kosten en mogelijke vervuiling met zware metalen geen realistische optie in de Nederlandse landbouw. 


\section{$1 \quad$ Inleiding}

\section{$1.1 \quad$ Beleidscontext}

Met het klimaatverdrag van Parijs is de urgentie voor klimaatmitigatie en -adaptatie hoog op de politieke en beleidsagenda gekomen. Dit heeft geleid tot nieuw klimaatbeleid met Europese reductiedoelstellingen en in Nederland het Klimaatakkoord. $\mathrm{CO}_{2}$-emissies uit organische bodems en koolstof(C-)vastlegging in minerale bodems gaan vanaf 2021 ook meetellen voor de nationale en Europese klimaatdoelstellingen.

Op Europees niveau is hiervoor in 2018 de zogenaamde LULUCF (Land Use, Land Use Change and Forestry) verordening (EU 2018/841) ${ }^{1}$ aangenomen, waarin beschreven staat hoe de landgebruiksector gaat meedoen in het klimaatbeleid. De belangrijkste afspraak is de zogenaamde nodebit rule, waarbij emissies, zoals berekend volgens vastgestelde boekhoudregels, niet mogen toenemen t.o.v. de referentieperiode. Als emissies afnemen, is er de mogelijkheid om credits te genereren, die tot een bepaald maximum mogen worden ingezet ter compensatie van broeikasgasemissies in de niet-ETS-sectoren (o.a. landbouw, transport en bouwsector). Hiermee is het belang van koolstofvastlegging in bodems en biomassa en het tegengaan van emissie in landgebruik (o.a. ontbossing en emissies uit veengronden) toegenomen en wordt het ook interessant voor andere sectoren om emissies te compenseren in landgebruik.

Tijdens de klimaatconventie in Parijs in 2015 is door Frankrijk het 4 per mille-initiatief gepresenteerd (Soussana et al., 2019). Dit initiatief heeft als doel om de uitdagingen van voedselzekerheid, klimaatadaptatie en klimaatmitigatie aan elkaar te koppelen door het stimuleren van koolstofvastlegging in bodems via duurzaam bodembeheer en het herstellen van gedegradeerde gronden. Een jaarlijkse toename van de bodem-C-voorraad met 4 promille, wat theoretisch mogelijk is, zou de toename van $\mathrm{CO}_{2}$ in de atmosfeer stoppen. Deze 4 promille moet niet gezien worden als een harde doelstelling, maar als een ambitieus doel op wereldschaal, waarbij duidelijk is dat de mogelijkheden voor C-vastlegging regionaal verschillen. In de wetenschap is er discussie in hoeverre dit doel inderdaad haalbaar is (Minasny et al., 2017; Poulton et al., 2018), maar het initiatief heeft in elk geval de mogelijke bijdrage van bodem C-vastlegging aan klimaatmitigatie op de kaart gezet.

In Nederland is op 28 juni 2019 het Klimaatakkoord gepresenteerd. In het akkoord is afgesproken dat ook landgebruik moet bijdragen aan de reductiedoelstellingen door het verminderen van emissies uit het veenweidegebied, meer C-vastlegging in bos en natuur en ook C-vastlegging in minerale landbouwbodems. Voor landbouwbodems is een doelstelling van 0,4-0,6 Mton $\mathrm{CO}_{2}$ vastlegging per jaar in 2030 vastgesteld. Om deze doelstelling te bereiken, is geld gereserveerd voor pilots, kennisverspreiding, technische innovaties en opleiding van adviseurs. Er is echter in het Klimaatakkoord nog geen specifiek beleid opgenomen die de toepassing van bodem-C-maatregelen stimuleert, terwijl dit op Europees niveau een steeds belangrijkere rol gaat spelen. Om de doelen van de Europese Green Deal te halen, wordt het Europese Gemeenschappelijke Landbouwbeleid (GLB) herzien. Een groot deel van het budget van het GLB moet ook gaan bijdragen aan klimaatmaatregelen. Hoe dit precies gaat uitpakken voor de Nederlandse landbouw is nog niet bekend, maar moet duidelijk worden in het Nationaal Strategisch Plan. In 2023 moet het herziene GLB van start gaan. De Europese Commissie noemt in elk geval al het behoud van blijvend grasland als belangrijke maatregel voor het stimuleren van koolstofvastlegging; daarnaast wordt ook nadruk gelegd op het beschermen van veenbodems en wetlands (EC, 2020).

Lesschen et al. (2012) hebben in 2012 een eerste analyse uitgevoerd naar de potentie voor $\mathrm{C}$-vastlegging in Nederlandse landbouwbodems en concludeerden dat een vastlegging van $1 \mathrm{Mton}^{\mathrm{CO}}$ per jaar haalbaar moet zijn. Dit is ruwweg $0,5 \%$ van de huidige broeikasgasemissies in Nederland en

\footnotetext{
1 https://ec.europa.eu/clima/policies/forests/lulucf_en
} 
ongeveer $5 \%$ van de emissies uit de landbouwsector. Deze berekening was gebaseerd op de zogenaamde IPCC-stock change-factoren, die zijn afgeleid op basis van langetermijnexperimenten in het buitenland. Voor Nederland waren er destijds nog weinig specifieke data over C-vastlegging in landbouwbodems beschikbaar. In het kader van het Klimaatakkoord heeft het ministerie van LNV daarom het Slim Landgebruik-programma² opgezet, om de kennis omtrent C-vastlegging in landbouwbodems te vergroten. Dit programma omvat o.a. analyses van langetermijnexperimenten, netwerken van boeren die met maatregelen aan de slag gaan, een landelijke meetcampagne, een praktijkmodel voor bodem-C en projecten gericht op communicatie en kennisverspreiding.

\subsection{Koolstofvastlegging in landbouwbodems}

De aanvoer van organische stof (OS) naar de bodem vanuit planten en plantaardig materiaal of aangevoerde organische meststoffen en de afbraak van organische stof door micro-organismen in de bodem is een continu proces, waarbij op lange termijn de aanvoer en afbraak elkaar in evenwicht houden. Door (tijdelijke) veranderingen in landgebruik en bodembeheer kan de aanvoer van organische stof worden verhoogd of de afbraak worden tegengegaan, waardoor de organischestofvoorraad in de bodem kan toenemen. Organische stof bestaat ruwweg voor de helft uit koolstof. Hierdoor wordt dus extra koolstof in de bodem vastgelegd en daarmee $\mathrm{CO}_{2}$ uit de atmosfeer verwijderd. De opgebouwde organische stof kan echter door veranderend bodembeheer ook weer afnemen, waardoor $\mathrm{CO}_{2}$ weer terug naar de atmosfeer gaat. Koolstofvastlegging in landbouwbodems is dus reversibel, waardoor er risico is op niet-permanente vastlegging. Dit geldt echter ook voor bossen en vele andere nature based-oplossingen.

De koolstof die wordt omgezet in biomassa en het gedeelte dat weer wordt gerespireerd door mens en dier, inclusief de mest die wordt geproduceerd, wordt omschreven als de 'korte C-kringloop'. Het gaat om $\mathrm{C}$ die uit de lucht wordt gehaald, maar die binnen afzienbare tijd weer terugkeert als $\mathrm{CO}_{2}$, als resultaat van respiratie en vertering van mest en gewasresten. Een deel van de $C$ uit biomassa blijft voor langere tijd in de bodem aanwezig als humus en wordt maar langzaam afgebroken. Dat gedeelte wordt tot de 'lange C-kringloop' gerekend, net als C in de biomassa van meerjarige vegetatie, aangezien de $\mathrm{C}$ voor langere tijd aan de atmosfeer wordt onttrokken. Vastlegging van $\mathrm{C}$ in de lange C-kringloop kan daarmee $\mathrm{CO}_{2}$-emissies uit fossiele brandstoffen compenseren. Veranderingen in de koolstofvoorraad in landgebruik (uitgesplitst naar boven- en ondergrondse biomassa, dood hout en minerale en organische bodems) worden dan ook meegeteld voor de internationale broeikasgasemissie rapportages in de categorie LULUCF.

De opbouw en afbraak van organische stof is een dynamisch proces en er is vaak een grote, ruimtelijke variatie aan organische stof in de bodem. Dat wordt o.a. bepaald door de oorsprong van de bodem (minerale versus organische bodems), bodemtextuur, landgebruik, vocht en temperatuur. De hoeveelheid koolstof in minerale bodems is in Nederland gemiddeld ongeveer 93 ton $\mathrm{C}$ per ha in de laag van 0 tot $30 \mathrm{~cm}$ en voor veenbodems gemiddeld 191 ton C per ha (Conijn en Lesschen, 2015). De variatie is echter groot en hangt af van bovengenoemde factoren. Ook het beheer van de bodem bepaalt de hoeveelheid organische stof in de bodem. Allereest door het landgebruik (blijvend grasland, tijdelijk grasland, akkerland), maar ook door de aanvoer van organische stof via gewasresten, mest, groenbemesters, compost en andere organische meststoffen.

De afbraak van organische stof kan worden beschreven als een zogeheten eerste-orde-proces. Een deel van de afgebroken organische stof verdwijnt als $\mathrm{CO}_{2}$, deels wordt het vastgelegd in microorganismen en een deel van de organische stof wordt omgezet naar een resistentere vorm (humus) met een lagere afbraaksnelheid als bijvoorbeeld micro-organismen doodgaan (necromass). De mate waarin organische stof wordt omgezet naar meer resistent materiaal, is de zogenaamde humificatiecoëfficiënt.

Bodemorganische stof is een belangrijke maat voor de bodemkwaliteit. Dit is een gevolg van positieve invloed van meer organische stof op onder meer de bodemstructuur, het vochtvasthoudend vermogen

2 https://slimlandgebruik.nl/ 
van de bodem, de voorraadvorming, de levering en benutting van nutriënten. Een bodem met meer organische stof kan over het algemeen meer water vasthouden. Organische stof is daarnaast ook de voedselbron voor micro-organismen in de bodem en draagt daardoor ook bij aan de biodiversiteit in de bodem. Een hoog organischestofgehalte op peil houden vraagt echter ook om een hogere aanvoer van organische stof, en kan mogelijk leiden tot extra lachgasemissie, afhankelijk van de $\mathrm{C} / \mathrm{N}$-verhouding van de aangevoerde organische stof (zie hoofdstuk 6).

Voor het kwantificeren van vastlegging (of verliezen) van organische koolstof in de bodem zijn metingen over langere tijd (minstens vijf tot tien jaar of langer) nodig, omdat het gaat om een relatief langzaam proces waarin op korte termijn slechts kleine veranderingen optreden ten opzichte van een grote voorraad. Aangezien er in Nederland maar weinig geschikte langetermijnexperimenten zijn, is het ook nodig om gebruik te maken van modellering. Met een model kan voor veel verschillende maagregelen en verschillende situaties de potentiële vastlegging worden berekend, waarmee een goede inschatting kan worden verkregen voor de nationale potentie voor bodem C-vastlegging. Er zijn veel verschillende modellen beschikbaar voor het modelleren van koolstof in de bodem; een overzicht kan worden gevonden in Lesschen et al. (2020), waarin een vergelijking is gemaakt van verschillende bodem C-modellen en hun geschiktheid voor toepassing als praktijkmodel binnen de Nederlandse landbouw.

\subsection{Koolstofvastlegging in biomassa en door steenmeel}

Naast $\mathrm{CO}_{2}$-vastlegging in bodems zijn er ook mogelijkheden voor $\mathrm{CO}_{2}$-vastlegging in biomassa. Binnen de landbouw gaat het dan met name om houtige gewassen in agroforestry-systemen en in landschapselementen zoals houtwallen. Het aanleggen van landschapselementen gaat echter wel deels ten koste van landbouwgrond, wat kan leiden tot veranderingen in landgebruik en mogelijk extra emissies elders. De focus van dit rapport is vooral gericht op landbouwbodems, maar voor de volledigheid wordt ook de potentiële C-vastlegging in agroforestry-systemen en landschapselementen meegenomen, om zo de verschillende potenties in perspectief te zetten. Tot nu toe ontbreekt nog een goede inschatting van de potentiële C-vastlegging voor agroforestry-systemen en landschapselementen voor Nederland.

Naast C-vastlegging van organische koolstof in bodems, is het ook mogelijk om $\mathrm{CO}_{2}$-emissies uit aanwending van kalk voor het beheren van bodem $\mathrm{pH}$ te voorkomen of door gebruik van steenmeel zelfs extra $\mathrm{CO}_{2}$ te binden (verhoogde verwering). Het op peil houden van de bodem-pH met silicaten gebeurt weinig in de landbouw, maar is normaal in de natuur. Bij de verwering van silicaten komt geen $\mathrm{CO}_{2}$ vrij en wordt net als bij kalk, afhankelijk van de hydrologische situatie, wel $\mathrm{HCO}_{3}-$ gevormd. Omdat in kalkloze landbouwbodems in het algemeen kalk gebruikt wordt om de pH geschikt te maken voor landbouwgewassen, is gebruik van silicaten potentieel een alternatief waardoor minder antropogene $\mathrm{CO}_{2}$-emissies optreden. Daarom is in dit rapport ook een onderdeel opgenomen (hoofdstuk 7) waar wordt berekend hoeveel $\mathrm{CO}_{2}$-emissie in Nederland voorkomen wordt indien silicaten gebruikt worden in de landbouw in plaats van kalk of hoeveel $\mathrm{CO}_{2}$ additioneel kan worden vastgelegd.

\section{$1.4 \quad$ Doelstelling}

De doelstelling van deze studie is om inzicht te geven in de technische potentie voor koolstofvastlegging in de Nederlandse landbouw. In dit rapport wordt op basis van de nieuwste inzichten en beschikbare data, o.a. uit het Slim Landgebruik-programma, een update gemaakt van de technische potentie van C-vastlegging in Nederlandse landbouwbodems. Hierbij wordt gebruikgemaakt van het RothC-model, een model dat de aanvoer en afbraak van koolstof in de bodem simuleert. De focus van het rapport ligt op koolstofvastlegging in minerale landbouwbodems, maar er wordt ook een inschatting gemaakt van de potentie voor vastlegging in biomassa in agroforestry-systemen en landschapselementen en de potentie voor minerale C-vastlegging door toepassing van steenmeel. De mogelijke risico's op veranderingen in de lachgasemissie als gevolg van het nemen van bodem-C- 
maatregelen worden ook behandeld in dit rapport. Deze resultaten dienen ter ondersteuning en onderbouwing van het huidige en toekomstige klimaatbeleid en voor kennisdoorwerking en communicatie naar de agrarische sector.

\subsection{Opzet van het rapport}

Het eerste deel van het rapport is gericht op de potentie voor C-vastlegging in minerale landbouwbodems. In hoofdstuk 2 worden verschillende maatregelen beschreven en is gekeken naar de potentie voor C-vastlegging op basis van (internationale) literatuur. In hoofdstuk 3 worden de aanpak en resultaten gepresenteerd van de technische potentie voor C-vastlegging in landbouwbodems, zoals gemodelleerd op nationale schaal met het RothC-model. In hoofdstuk 4 wordt de potentiële koolstofvastlegging in landschapselementen beschreven en in hoofdstuk 5 die in agroforestry-systemen. Ook hebben we in dit rapport aandacht voor de mogelijke risico's op toename van lachgasemissies door toepassing van bodem-C-maatregelen en deze literatuurreview staat beschreven in hoofdstuk 6 . In hoofdstuk 7 is een discussie opgenomen over de potentie voor minerale C-vastlegging door het gebruik van steenmeel. Ten slotte worden in hoofdstuk 8 de conclusies van het gehele rapport samengevat en aanbevelingen gepresenteerd. 


\section{Beschrijving bodem-C-maatregelen}

In verschillende studies zijn al overzichten en beschrijvingen van relevante bodem-C-maatregelen gegeven (o.a. Staps et al., 2017; Van Eekeren et al., 2018). De meeste van de maatregelen kunnen gegroepeerd worden in drie hoofdgroepen (volgens de leidende principes):

- Maatregelen die de afbraak van organisch materiaal in de bodem beperken;

- Maatregelen die zorgen voor de netto aanvoer en vastlegging van organische stof binnen het eigen bedrijf;

- Maatregelen die zorgen voor de netto aanvoer en vastlegging van organische stof van buiten het eigen bedrijf op het eigen bedrijf.

In dit hoofdstuk wordt een beschrijving gegeven van de maatregelen die mogelijk relevant zijn voor toepassing onder Nederlandse landbouwcondities. Voor de meeste van deze maatregelen is ook potentie voor C-vastlegging berekend met het RothC-model (zie hoofdstuk 3). Echter voor nietkerende grondbewerking, kruidenrijkgrasland en diep wortelende gewassen was het niet mogelijk om deze potentie te kwantificeren vanwege onvoldoende data voor een modelberekening of bewijs voor effectiviteit. Een deel van de maatregelen is gericht op de akkerbouw, terwijl andere maatregelen relevant zijn voor de grasland gebaseerde (melk)veehouderij.

\subsection{Verhogen aandeel rustgewassen in rotatie}

Gewasrotatie wordt voornamelijk toegepast om de kans op plagen, ziektes en onkruid te verminderen. Sinds de komst van kunstmest en bestrijdingsmiddelen is gewasrotatie minder belangrijk geworden. Hierdoor kon het aandeel winstgevende gewassen toenemen. Deze gewassen, zoals snijmais, suikerbieten, aardappelen en uien, nemen veel nutriënten op uit de bodem en laten relatief weinig gewasresten achter na de oogst. Een rotatie met veel van dit soort gewassen zorgt dus voor een relatief lage aanvoer van organische stof en een uiteindelijk een afname in bodem-organischestof en nutriënten. Als het aandeel rustgewassen (bv. graangewassen of grassen) verhoogd wordt in de gewasrotatie nemen de organischestof-aanvoer en dus het organischestofgehalte in de bovengrond en de koolstofvastlegging toe (Van Dijk et al., 2012; Koopmans et al., 2020). Een bijkomend voordeel van een gewasrotatie met meer rustgewassen is dat het de microbiële samenstelling (Collins et al., 1992) en de fysische en chemische bodemeigenschappen kan verbeteren (Blair and Crocker, 2000). Tussen 2007 en 2017 is in Nederland het aandeel rustgewas in de gewasrotatie bij vrijwel alle gespecialiseerde akkerbouwbedrijven afgenomen, gemiddeld met 18\% (Smit en Jager, 2018).

West en Post (2002) hebben een literatuuronderzoek uitgevoerd naar de potentiële koolstofvastlegging door verbeterde gewasrotatie. De studie vergeleek (i) het verbouwen van één continu geteeld gewas met voortdurende gewasrotatie, (ii) graan-braak-rotatie met (voortdurende) gewasrotatie, en (iii) gewasrotatie met twee gewassen met gewasrotatie met drie of meer gewassen. Het effect van een verbeterde gewasrotatie op koolstofvastlegging was gemiddeld 0,8 ton $\mathrm{CO}_{2} /$ ha/jaar.

Voor Nederlandse condities werd een koolstofvastlegging van 0,62 ton $\mathrm{CO}_{2} / \mathrm{ha} / \mathrm{jaar}$ berekend voor een rotatie met meer graan (van 20 naar $40 \%$ ) en 1,43 ton $\mathrm{CO}_{2} / \mathrm{ha} / \mathrm{jaar}$ voor een alternatieve rotatie met winterpeen in plaats van suikerbiet, 50\% graan en maximale groenbemesters (Van Dijk et al., 2012). Financieel is het niet aantrekkelijk om te veel rustgewassen in de gewasrotatie op te nemen, maar voor duurzaam bodembeheer is het wel noodzakelijk. 


\subsection{Blijvend grasland}

In 2019 kent Nederland in totaal 906.780 ha aan tijdelijk en blijvend grasland in landbouwkundig gebruik, waarvan ongeveer $76 \%$ als blijvend grasland (CBS Statline). Blijvend grasland is grasland met een minimale leeftijd van 5 jaar. De laatste jaren neemt het areaal blijvend grasland weer toe. Dit komt onder andere doordat de melkveestapel groeide sinds het afschaffen van het melkquotum in 2015 en door de toenemende vraag naar grondgebonden melkveehouderij. Daarnaast draagt de derogatie bij aan het aandeel blijvend grasland, aangezien melkveehouders minimaal $80 \%$ grasland moeten hebben om gebruik te kunnen maken van de derogatie en meer dan $170 \mathrm{~kg}$ stikstof uit dierlijke mest per hectare grond te kunnen gebruiken (CBS, 2016).

Blijvend grasland draagt bij aan een goede bodemkwaliteit en meer dan tijdelijk grasland of grasland in een rotatie. Doordat de aanvoer van organische stof uit de gewasresten van gras (zowel boven- als ondergronds) hoog is en de afbraak relatief laag, bouwt het organischestofgehalte van de bodem zich op. Dit komt ten goede aan de grasproductie, het bodemleven, maar ook aan het watervasthoudend vermogen. Het scheuren van grasland, bijvoorbeeld voor graslandvernieuwing of de (tijdelijke) teelt van mais, heeft nadelige gevolgen doordat de organische stof wordt afgebroken en de aanvoer van organische stof uit gewasresten afneemt. Wanneer het grasland gescheurd wordt, stopt de opbouw van organische stof en wordt door de verstoring een deel van de organische stof relatief snel afgebroken. Tevens worden het bodemleven en haar functies verstoord (Van Eekeren et al., 2016). Het niet-scheuren van grasland kan dus zorgen voor een hogere organischestof-opbouw en een betere bodemstructuur en waterinfiltratie. Voornamelijk in de bovenste $10 \mathrm{~cm}$ kan de koolstofvoorraad significant toenemen (Van Eekeren et al., 2008; De Wit et al., 2018).

Er is verschillend onderzoek gedaan naar het effect van blijvend grasland en het voorkomen of vertragen van scheuren op de koolstofopbouw in de bodem. Een studie in Ierland op klei in een 43 jaar oud langetermijnexperiment toont dat er een significante opbouw van bodemkoolstof plaatsvindt zolang grasland niet wordt gescheurd. Daarnaast is er na 43 jaar nog geen verzadiging opgetreden in opbouw van organische stof in de bodem. Dit impliceert dat graslanden voor een lange periode additionele koolstof kunnen opslaan (Fornara et al., 2016). Een andere studie in Ierland op klei heeft onderzocht wat het effect van graslandvernieuwing is op het bodem-organischestofgehalte t.o.v. het niet-scheuren van grasland. Door het vernieuwen van grasland ontstond er een significante afname van het organische koolstofgehalte met 32,2 ton C/ha (ongeveer $25 \%$ van de voorraad) in de 2,5 jaar na het scheuren (Figuur 1). De meeste koolstof (86\%) ging verloren in de eerste vier maanden na het scheuren (Necpálová et al., 2014).

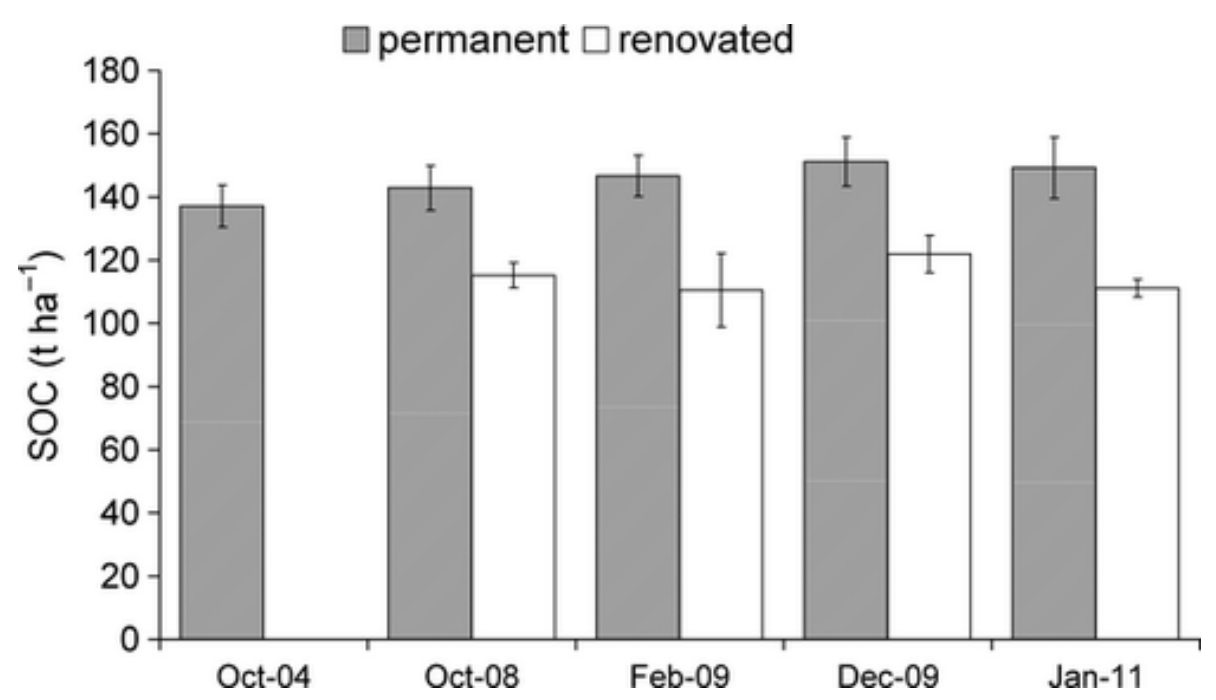

Figuur 1 Bodem-C-voorraad (SOC) op 0-30 cm diepte onder blijvend grasland en vernieuwd grasland tijdens vier meetmomenten na het scheuren van grasland in 2004 (Necpálová et al., 2014). 
Resultaten uit Nederlandse langetermijnexperimenten tonen met name op klei een significante $\mathrm{CO}_{2}-$ vastlegging. Koopmans et al. (2019) vinden in de laag 0-30 cm een vastlegging van 6,1 ton $\mathrm{CO}_{2} / \mathrm{ha} / \mathrm{jaar}$ op grasland, variërend in leeftijd tussen 9 en 19 jaar oud, vergeleken met grasland van 0 jaar oud. Voor grasland ouder dan 20 jaar (gemiddeld 26 jaar) is de vastlegging zelfs 8,7 ton $\mathrm{CO}_{2} /$ ha/jaar. Onderzoek toont hier aan dat de vastlegging met name in de eerste $10 \mathrm{~cm}$ plaatsvindt. Op zand werd geen significant effect waargenomen. Koopmans et al. (2020) vinden vergelijkbare resultaten, waarbij in de $0-30 \mathrm{~cm}$-laag een significante toename van 5,4 ton $\mathrm{CO}_{2} / \mathrm{ha} /$ jaar wordt gevonden op klei. Ook hier is geen significant effect op zandgronden waargenomen. Een mogelijke verklaring hiervoor is het feit dat het organischestofgehalte in de gemeten zandbodems relatief hoog is $(3,5$ tot $3,9 \%)$, waardoor een effect minder goed meetbaar is.

Naast het positieve effect op het organischestofgehalte tonen Iepema et al. (2020) tevens aan dat het voorkomen van scheuren van grasland een positief effect heeft op de bodemkwaliteit. Iepema et al. (2020) tonen aan dat de bodemorganische $\mathrm{C}, \mathrm{N}$ en potentieel mineraliseerbare stikstof (PMN) lager zijn in jong grasland dan in oud grasland. Dit benadrukt de verliezen van $\mathrm{C}$ en $\mathrm{N}$ als gevolg van het ploegen. Daarnaast neemt het watervasthoudend vermogen significant toe naarmate grasland ouder wordt.

\subsection{Aanvoer externe organische stof}

\subsubsection{Vaste mest}

In Nederland wordt veel mest geproduceerd met ruim 74,6 miljoen ton in 2019. Het grootste deel van deze productie, $96,4 \%$, is dunne mest afkomstig van melkvee (Van Bruggen \& Gosseling, 2020).

Drijfmest wordt vaak gebruikt in de akkerbouw en melkveehouderij als meststof, maar bevat minder organische stof dan vaste mest. Vaste mest wordt gekenmerkt als een vorm van steekbare (vaste) mest. Aan de vaste mest is vaak een variabele hoeveelheid strooisel toegevoegd, met name wanneer de mest afkomstig is van potstallen of grupstallen (De Wit et al., 2020). Naast deze traditionele vaste mest zijn er tegenwoordig ook producten van mestscheiding, waarbij de organische stof met name in de dikke fractie zit. De samenstelling van deze dikke fracties hangt af van de manier van mestscheiding en verwerking. De afgelopen tijd ontstaan er steeds meer initiatieven om drijfmest te vervangen door vaste mest. Een van de argumenten voor deze verschuiving van drijfmest naar vaste mest is dat vaste mest meer effectieve organische stof zou bevatten, waardoor het bodemorganischestofgehalte kan toenemen.

Voor het bepalen van het effect van organische meststoffen op bodem-organische stof is het belangrijk te kijken naar de hoeveelheid vast materiaal die wordt aangevoerd. Wanneer mest onverteerde voedergewassen bevat, aangevuld met stro in het geval van een potstal of grupstal, ontstaat een hoog gehalte aan complexe substanties in de mest. Deze complexe substanties, zoals lignine, ontbinden minder snel in de bodem, waardoor er op de lange termijn meer organische stof achterblijft in de bodem (Magdoff \& Van Es, 2009), alhoewel mogelijk ook in de bodem dit soort complexe componenten gevormd worden. Tabel 1 toont een overzicht van de effectieve organische stof van verschillende meststoffen die in Nederland wordt toegepast. Met name vaste mest en compost kennen een hoog gehalte effectieve organische stof (EOS).

Maillard en Angers (2014) hebben een meta-analyse uitgevoerd naar het effect van dierlijke mest op het organische koolstofgehalte in de bodem. Hierbij zijn 42 meerjarige bemestingsstudies meegenomen in de analyse. Een van de conclusies van het onderzoek was dat het gebruik van dierlijke mest een significante bijdrage levert aan de bodem-organischestofbalans. Daarnaast toonde de studie aan dat vaste mestsoorten, zoals de dikke fractie van rundermest en vaste rundermest, meer koolstof in de bodem vastleggen dan drijfmest. Dit volgt ook uit een Zwitserse studie die liet zien dat vaste mest meer koolstof vastlegt dan drijfmest op basis van dezelfde hoeveelheid stikstofbemesting (Maltas et al., 2018). 
Tabel 1 Overzicht van de aanvoer van verse organische stof (OS) en effectieve organische stof (EOS), de resterende hoeveelheden na vijf en tien jaar na toediening en de $\mathrm{C} / \mathrm{N}$-verhouding van verschillende mestsoorten (Bron: Handboek bodem en bemesting) ${ }^{3}$.

\begin{tabular}{|c|c|c|c|c|c|c|c|c|c|}
\hline \multirow[t]{2}{*}{ Organische mest } & \multirow{2}{*}{$\begin{array}{r}\text { OS } \\
\text { (kg/ton) }\end{array}$} & \multirow{2}{*}{$\begin{array}{r}\text { H.C. }{ }^{1} \\
\text { (fractie) }\end{array}$} & \multirow{2}{*}{$\begin{array}{r}\text { EOS } \\
\text { (kg/ton) }\end{array}$} & \multirow{2}{*}{$\begin{array}{r}\mathrm{EOS} / \mathrm{P}_{2} \mathrm{O}_{5}{ }^{2} \\
(\mathrm{~kg} / \mathrm{kg})\end{array}$} & \multicolumn{2}{|c|}{ na 5 jaar $^{3}$} & \multicolumn{2}{|c|}{ na 10 jaar $^{3}$} & \multirow[t]{2}{*}{$\mathrm{C} / \mathrm{N}^{4}$} \\
\hline & & & & & (kg/ha) & (fractie) & (kg/ha) & (fractie) & \\
\hline \multicolumn{10}{|l|}{ Drijfmest } \\
\hline Rundvee & 71 & 0,70 & 50 & 33 & 26 & 0,36 & 18 & 0,26 & 17 \\
\hline Vleesvarkens & 79 & 0,33 & 26 & 7 & 7 & 0,09 & 5 & 0,06 & 12 \\
\hline Zeugen & 25 & 0,34 & 9 & 2 & 2 & 0,10 & 2 & 0,06 & 7 \\
\hline Rosékalveren & 71 & 0,70 & 50 & 19 & 26 & 0,36 & 18 & 0,26 & 14 \\
\hline Witvleeskalveren & 17 & 0,70 & 12 & 11 & 6 & 0,36 & 4 & 0,26 & 17 \\
\hline \multicolumn{10}{|l|}{ Vaste mest } \\
\hline Rundvee grupstal & 155 & 0,70 & 109 & 25 & 56 & 0,36 & 40 & 0,26 & 12 \\
\hline Varkens (stro) & 153 & 0,33 & 50 & 6 & 14 & 0,09 & 9 & 0,06 & 14 \\
\hline Pluimvee & 416 & 0,33 & 137 & 7 & 39 & 0,09 & 25 & 0,06 & 8 \\
\hline Pluimvee + nadroog & 393 & 0,33 & 130 & 5 & 35 & 0,09 & 24 & 0,06 & 7 \\
\hline Kippenstrooiselmest & 359 & 0,34 & 122 & 5 & 35 & 0,10 & 22 & 0,06 & 7 \\
\hline Vleeskuikens + parelhoen & 419 & 0,36 & 151 & 9 & 45 & 0,11 & 29 & 0,07 & 8 \\
\hline Vleeskalkoenen & 427 & 0,36 & 154 & 8 & 45 & 0,11 & 29 & 0,07 & 12 \\
\hline Schapen & 195 & 0,70 & 137 & 30 & 70 & 0,36 & 50 & 0,26 & 14 \\
\hline Geiten & 174 & 0,70 & 122 & 23 & 63 & 0,36 & 45 & 0,26 & 12 \\
\hline \multicolumn{10}{|l|}{ Compost } \\
\hline Champost & 211 & 0,50 & 106 & 24 & 40 & 0,19 & 26 & 0,13 & 15 \\
\hline GFT-compost & 242 & 0,90 & 218 & 50 & 165 & 0,68 & 136 & 0,56 & 13 \\
\hline Groencompost & 179 & 0,90 & 161 & 73 & 122 & 0,68 & 101 & 0,56 & 18 \\
\hline
\end{tabular}

${ }^{1}$ H.C. = humificatiecoëfficiënt: de fractie die één jaar na toediening van het vers organisch materiaal nog over is in de bodem.

2 EOS-aanvoer $(\mathrm{kg})$ per $\mathrm{kg}$ fosfaat in de mest

${ }^{3}$ De hoeveelheid die 5 en 10 jaar na toediening van het vers organische materiaal nog over is in kg per ha en als fractie van de beginhoeveelheid.

${ }_{4} \mathrm{C} / \mathrm{N}$-verhouding van de organische stof in de mest $(\mathrm{C} / \mathrm{N}$-org).

Vaste mestsoorten bieden naast een positieve bijdrage aan het bodem-organischestofgehalte ook een positief effect op andere bodemindicatoren en overige diensten. Het effect van vaste mest op het bodemleven is over het algemeen positief, met name door de hogere aanvoer van organische stof (De Wit et al., 2020; Koopmans et al., 2018). Dit effect is over het algemeen groter naarmate de bodem minder organische stof bevat en dus over het algemeen groter op bouwland dan op grasland (Van Eekeren et al., 2009). Ook de manier van aanwending van vaste mest t.o.v. drijfmest heeft invloed op het bodemleven, doordat vaste mest bovengronds wordt uitgereden en drijfmest wordt geïnjecteerd in de bodem (De Wit et al., 2009). Ook verbetert de bodemstructuur bij een hogere aanvoer van organische stof (Koopmans et al., 2018).

\subsubsection{Compost}

De aanwending van compost kan de bodemkwaliteit verbeteren, het organischestofgehalte verhogen en de uitspoeling van nutriënten voorkomen door ze te immobiliseren en vast te houden in de bodem. Tegelijk is er een behoefte aan hergebruik van reststromen in het thema van een circulaire economie (Koopmans et al., 2018) en neemt de beschikbare hoeveelheid compost toe. Er zijn verschillende soorten compost, namelijk van dierlijke mest, plantaardig groencompost en gft-compost of een mengsel van bovengenoemde soorten (Koopmans et al., 2018).

\footnotetext{
3 https://www.handboekbodemenbemesting.nl/nl/handboekbodemenbemesting/Handeling/Organischestofbeheer/Organische-stofbalans/Kengetallen-organische-stof.htm
} 
Op basis van de maximale $\mathrm{N}$ - en P-bemestingsnormen zou de toegestane toediening van compost ongeveer $6000 \mathrm{~kg}$ droge stof/ha per jaar zijn (Koopmans en Bloem, 2018). Echter, een boer heeft de vrijheid om binnen zijn bedrijf een andere verdeling toe te passen en kan ook kiezen voor een grotere hoeveelheid compost eens in de zoveel jaar. In een studie van Koopmans en Bloem (2018) werden verschillende soorten compost vergeleken met de gangbare bemesting (minerale meststof, drijfmest etc.). Na 17 jaar gaf de groencompost de grootste verhoging in bodem-C-gehalte (van 1,6\% in het begin tot $2,3 \%$ aan het eind van het experiment; een verhoging van $41 \%$ ) op een calciumrijke leembodem. De hoge C-opbouw na compost komt door de hoge humificatiecoëfficiënt, waarbij in verschillende composten na 1 jaar nog $89-93 \%$ van de C aanwezig is (Van Groenigen en Zwart, 2007). Dit kan verklaard worden doordat tijdens de compostering resistentie en recalcitrante verbindingen worden gevormd en de makkelijk afbreekbare organische stof al deels in $\mathrm{CO}_{2}$ is omgezet.

In de langetermijnexperimenten, die in het Slim Landgebruik-programma zijn geanalyseerd, is het effect van 20 en 40 ton compost onderzocht t.o.v. kunstmest. Op de centrale klei resulteerde dit in een $\mathrm{CO}_{2}$-vastlegging van 1,8 ton $\mathrm{CO}_{2} / \mathrm{ha} / \mathrm{jaar}$ bij 20 ton compost en 4 ton $\mathrm{CO}_{2} / \mathrm{ha} / \mathrm{jaar}$ bij 40 ton compost (Koopmans et al., 2020). Een ander langetermijnexperiment (Mest als Kans) vergelijkt verschillende organische meststoffen met elkaar. De studie laat een toename aan organischestofgehalte in de bodem zien tussen 1999 en 2006 voor aanwending van natuurcompost, gft-compost en verse potstalmest, terwijl het OS-gehalte bij dunne rundveemest afnam (Bokhorst et al., 2008).

Een studie op een zandige bodem in Canada liet zien dat uit verschillende maatregelen (niet-kerende grondbeweging, tussengewassen, compost) alleen compost een verhoging van bodem-C opleverde (Whalen et al., 2008). Een studie die de potentie van verschillende maatregelen laat zien om bodem-C te verhogen in Europa gaf aan dat composttoediening 0,4 ton $\mathrm{C} \mathrm{ha}^{-1}$ jaar $^{-1}$ zou kunnen vastleggen in Europese bodems, gebaseerd op een toediening van 20 ton compost per ha per jaar (Freibauer et al., 2004).

\subsubsection{Bokashi}

Bokashi is het eindproduct van een fermentatieproces van restproducten, o.a. plantenresten van de landbouw, bermmaaisel en gft-afval (Olle, 2021). Bokashi lijkt veel op compost, het heeft ook een hoog organischestof- en nutriëntengehalte (Quiroz and Céspedes, 2019). Omdat er zoveel verschillende inputmaterialen gebruikt (kunnen) worden, is bokashi erg verschillend van kwaliteit (Quiroz and Céspedes, 2019). Zo heeft bokashi gemaakt van gft-afval bijvoorbeeld een hoger gehalte aan nutriënten dan bokashi gemaakt van bermmaaisel (Romkens et al., 2020). Omdat fermentatie een anaeroob proces is, is de afbraak van organische stof veel lager en blijft meer koolstof behouden in vergelijking met (aerobe) compostering. De vraag is echter in hoeverre deze $C$ stabiel is en na toepassing in de bodem ook bijdraagt aan C-vastlegging. Effecten van bokashi op de bodemkoolstofopslag zijn, net zoals bij compost en dierlijk mest, pas op de langere termijn zichtbaar (Romkens et al., 2020). Resultaten van langetermijnexperimenten met bokashi zijn vooralsnog niet beschikbaar, daarom kan er nog geen uitspraak worden gedaan over de effecten van bokashi op $\mathrm{CO}_{2}-$ vastlegging in de bodem. In hoofdstuk 3 is daarom voor het doorrekenen van de maatregelen alleen uitgegaan van compost.

\subsubsection{Biochar}

Een andere mogelijke externe aanvoer van koolstof naar de bodem is biochar. Biochar is een houtskoolachtige stof die geproduceerd wordt door organisch materiaal onder zuurstofloze omstandigheden te verhitten op een temperatuur van minimaal $350^{\circ} \mathrm{C}$. Dit proces wordt pyrolyse genoemd en resulteert in syngas, pyrolyse-olie en biochar. De verhouding tussen deze drie producten hangt af van de temperatuur en druk waaronder de pyrolyse wordt uitgevoerd. Biochar kan gemaakt worden van veel verschillende organische grondstoffen, waaronder gewasresten, mest, hout en de residuen van afvalwater. De interesse in biochar is de laatste jaren toegenomen vanwege de potentie voor koolstofvastlegging, aangezien biochar veel stabieler is dan de oorspronkelijke koolstof van het organisch materiaal. Dit betekent dat de koolstof in de biochar gedurende eeuwen of millennia in de bodem vastgehouden kan blijven (Joseph et al., 2021). Daarnaast kan biochar ook positieve effecten 
hebben op andere bodemeigenschappen en mogelijk resulteren in hogere gewasopbrengsten. Echter dit effect op gewasopbrengst wordt met name gevonden in nutriëntarme tropische bodems (Joseph et al., 2021). Onderzoek onder Nederlandse omstandigheden heeft deze positieve effecten echter niet aangetoond. Zo zou biochar zou ook het watervasthoudend vermogen van de bodem kunnen verbeteren, aangezien de porositeit van het materiaal hoog is. Jeffrey et al. (2015) vonden in een experiment op Nederlandse zandbodem echter geen effect wat verklaard werd door het hydrofobe karakter van de biochar. Mogelijk kan biochar nog wel de emissie van lachgas verminderen (Guenet et al., 2020). Biochar heeft dus zeker potentie voor C vastlegging, maar biedt dus geen andere voordelen voor bodemvruchtbaarheid in tegenstelling tot andere organische meststoffen zoals compost. Het EU Fertiplus ziet vooral mogelijkheden voor combinatie van biochar en andere organische meststoffen in de tuinbouw en in niche markten (Sánchez-Monedero et al., 2019). Gezien de sterke concurrentie voor biomassa als biogrondstof of voor bio-energie, de hoge productiekosten en de geringe impact op bodemkwaliteit is het niet de verwachting dat biochar in Nederland grootschalig toegepast zal worden. Daarom is biochar niet als aparte maatregel in deze studie meegenomen.

\subsection{Vanggewassen/groenbemesters}

Groenbemesters worden gezaaid buiten het groeiseizoen met als functie of bemester in het na- of voorjaar als de groenbemester wordt ondergeploegd (Blanco-Canqui et al., 2015), of als vanggewas om uitspoeling van nutriënten te voorkomen (Thorup-Kristensen, 2001). Verder is het in Nederland van belang dat de gekozen groenbemesters niet een waardplant zijn voor plant-parasitaire aaltjes. Om dit te voorkomen, zijn sommige groenbemesters ontwikkeld die resistent zijn voor infectie met juist deze aaltjes en zo de ziektedruk te verminderen (Haagsma et al., 2019), bijvoorbeeld bladrammenas Er zijn meerdere soorten groenbemesters die veel gebruikt worden in Nederland (Haagsma et al., 2019):

- Grasachtigen: Engels en Italiaans raaigras en Japanse Haver

- Vlinderbloemigen: klaver en voederwikke

- Kruisbloemigen: bladrammenas en gele mosterd

- Overigen: afrikaantjes en facelia

- Mengsels: in het kader van de vergroeningsregeling van het GLB wordt het gebruik van mengsels gestimuleerd

De keuze van groenbemester hangt af van eigenschappen van een perceel, zoals structuur, beschikbare nutriënten, aaltjes, erosiegevoeligheid en ook klimaatfactoren (vorstgevoeligheid). Verder kunnen sommige groenbemesters, zoals klavers, beter zo vroeg mogelijk in de zomer worden gezaaid om nog behoorlijke biomassa te verkrijgen als er voldoende vocht beschikbaar is. Andere groenbemesters kunnen nog tot begin september worden gezaaid. Wel geldt dat ook hier de biomassa bij late zaai flink afneemt (Koopmans et al., 2020). In het recente verleden was het moment van vrijkomen van percelen bijna volledig bepalend voor de groenbemesterkeuze. Gechargeerd gesteld: na vroeg ruimende gewassen was de logische keuze grassen of bladrammenas, in geval van laat ruimende gewassen bleef gele mosterd of rogge over. Nu wordt de keuze ook steeds meer gebaseerd op het volggewas.

Verplichte teelt van groenbemesters

Bij maisteelt is het - voor telers op zand en löss - verplicht om een vanggewas te telen. Vanaf 2019 is dit aan datums gebonden. Bij snijmais moet het vanggewas vóór 1 oktober gezaaid te zijn. Voor korrelmais, Corn Cob Mix (CCM) en maiskolvenschroot (MKS), suikermais of biologisch geteelde mais geldt 31 oktober als uiterlijke datum. Bij consumptie- of zetmeelaardappelteelt op zand en löss is het vanaf 2021 verplicht om een vanggewas te zaaien. Aardappeltelers moeten dan voor 16 september een groenbemester zaaien. Lukt dat vanwege een latere oogst niet, dan moet er uiterlijk 31 oktober een wintergraan als vanggewas gezaaid worden (Haagsma et al., 2019). In 2017 werd op 50\% van het akkerbouwareaal in Nederland een groenbemester geteeld. Bladrammenas, gele mosterd en Italiaans raaigras werden het meest geteeld. 


\section{Koolstofvastlegging in bodem}

Groenbemesters kunnen bijdragen aan klimaatmitigatie, doordat alle biomassa weer wordt gemengd met de bodem en dus koolstof wordt vastgelegd in het systeem. Daarnaast worden groenbemesters ingezet om het uitspoelen van nutriënten in de herfst te voorkomen (Rietbert et al., 2013).

Twee meta-analyses, over studies wereldwijd verspreid, laten zien dat groenbemesters het C-gehalte in de bodem met 0,32 $\pm 0,08 \mathrm{Mg} \mathrm{ha}^{-1} \mathrm{yr}^{-1}$ verhogen (Poeplau and Don, 2015) en 15,5\% bodemorganische $\mathrm{C}$ kunnen vastleggen (Jian et al., 2020). De $\mathrm{CO}_{2}$ die vastgelegd kan worden, hangt sterk af van de groenbemester en de zaaitijd. Over het algemeen geldt dat vroeger zaaien vaak (meer dan) twee keer zoveel biomassa oplevert en dus ook navenant zoveel meer $\mathrm{CO}_{2}$ wordt vastgelegd. In Nederland wordt aangeraden om de groenbemester voor 1 oktober te zaaien.

Voor Nederland zijn er nog weinig experimenten beschikbaar waarin gekeken is naar het effect van groenbemesters op C-vastlegging. Een langetermijnexperiment op zandgrond, waarbij de inzet van verschillende groenbemesters is vergeleken met zwarte braak, toont tot op heden nog geen significant effect (Koopmans et al., 2021). Een mogelijke verklaring voor het ontbreken van significante resultaten kan de korte looptijd van de proef zijn (slechts vijf jaar).

Modelberekeningen, die over een tijdsperiode van tien jaar kijken, laten zien dat er door de inzet van groenbemester tussen de 0,92 en 1,01 ton C/ha/jaar extra vastgelegd kan worden. Als de inzet van groenbemesters gecombineerd wordt met een verbeterde gewasrotatie kan er zelfs 1,43 ton $\mathrm{CO}_{2} / \mathrm{ha} / \mathrm{jaar}$ extra vastgelegd worden, afhankelijk van het geteelde gewas en de gekozen groenbemester (Koopmans et al., 2020). Koopmans et al. (2020) en Selin Norén (2021) hebben de kengetallen voor de effectieve organischestof-aanvoer voor groenbemesters geactualiseerd. Met deze actualisatie kan de bijdrage van groenbemesters aan de koolstofvastlegging beter ingeschat worden.

Andere voordelen van groenbemesters en vanggewassen

Naast een bijdrage aan koolstofvastlegging in de bodem kunnen groenbemesters en vanggewassen ook andere positieve effecten op de bodem hebben. Zo is bekend dat vooral vanggewassen minerale $\mathrm{N}$ opnemen in hun biomassa. Dit kan, afhankelijk van de zaaidatum, de uitspoeling tot bijna nul terugbrengen (Thapa et al., 2018). Verder geven de groenbemesters, als ze een korte tijd voor het hoofdgewas worden ondergeploegd, een N-gift. Dit kan dus de benodigde kunstmestbehoefte van het hoofdgewas verlagen. Andere positieve effecten van groenbemesters zijn bijvoorbeeld minder erosie, minder ziektes/aaltjes, een hogere microbiële diversiteit in de bodem, onkruidpreventie, meer mycorrhiza-schimmels en P-beschikbaarheid en een betere bodemstructuur (Blanco-Canqui et al., 2015).

\section{Groenbemesters en $\mathrm{N}_{2} \mathrm{O}$-emissies}

Door de extra toevoer van koolstof samen met stikstof kunnen $\mathrm{N}_{2} \mathrm{O}$-emissies stijgen net na het incorporeren van groenbemesters in de grond. Twee meta-analyses van data van over de hele wereld laten zien dat er geen eenduidig effect van groenbemesters op $\mathrm{N}_{2} \mathrm{O}$-emissies is gevonden (Abdalla et al., 2019; Basche et al., 2014). In ongeveer $60 \%$ van de gevallen stijgen $\mathrm{N}_{2} \mathrm{O}$-emissies, terwijl bij de andere $40 \% \mathrm{~N}_{2} \mathrm{O}$-emissies afnemen (Basche et al., 2014), maar een oorzakelijk verband is niet aangetoond en dit maakt management van die nadelige $\mathrm{N}_{2} \mathrm{O}$-emissies moeilijk tot onmogelijk op dit moment. Abdalla et al. (2019) suggereren dat $\mathrm{N}_{2} \mathrm{O}$-emissies zijn te voorkomen door de $\mathrm{N}$-bemesting van het hoofdgewas aan te passen na het onderwerken van de groenbemesters.

\subsection{Gewasresten achterlaten}

Het koolstofgehalte in bodems neemt over het algemeen toe als gevolg van het achterlaten van gewasresten. Gewasresten bestaan uit stengels, stoppels, bladeren en wortels. In sommige gevallen worden de gewasresten van het veld gehaald, om bijvoorbeeld te gebruiken als veevoeder, als stro in stallen of als een bron voor bio-energie. Gewasresten die direct op het land achterblijven, dragen naast koolstofvastlegging bij aan het verminderen van bodemerosie, verbeteren de bodemkwaliteit en -vruchtbaarheid, vormen een bron van nutriënten voor het opvolgende gewas en hebben een positief effect op waterinfiltratie en -opslag (Paulsen et al., 2020; Cherubin et al., 2017). In een aantal 
gevallen komen gewasresten, al dan niet na mengen of bewerking, alsnog terug op het veld (bijvoorbeeld stro in mest of dierlijke mest sec).

Naast het vastleggen van koolstof zorgen gewasresten ook voor een toename in $\mathrm{CO}_{2}-$ en $\mathrm{N}_{2} \mathrm{O}$ emissies. $\mathrm{CO}_{2}$-emissies kunnen tot zes keer toenemen als gevolg van het inwerken van gewasresten, doordat gewasresten relatief veel gemakkelijk afbreekbaar koolstof bevatten. Hierdoor wordt de microbiële activiteit, en dus respiratie, gestimuleerd. Deze turnover van organische stof die leidt tot $\mathrm{CO}_{2}$ wordt tot de korte C-cyclus gerekend. Overigens zullen de gewasresten ook afbreken wanneer deze worden gebruikt als stro voor stalbedekking of verbrand voor energievoorziening, waardoor het netto-effect van de $\mathrm{CO}_{2}$-emissie klein zal zijn. Het type gewasrest kan tevens van invloed zijn op de emissies; zo heeft stro een relatief hoge $\mathrm{C} / \mathrm{N}$-ratio waardoor deze minder snel afbreekt en $\mathrm{CO}_{2}$ - en $\mathrm{N}_{2} \mathrm{O}$-emissies lager blijven (Lehtinen et al., 2014).

Over het algemeen zijn wetenschappers het met elkaar eens over het feit dat het achterlaten van gewasresten leidt tot een toename van het SOC-gehalte. Een reviewstudie van Lehtinen et al. (2014) rapporteert een gemiddelde toename van het organische koolstofgehalte met $7 \%$, gebaseerd op 37 langetermijnexperimenten in Europa. Een langetermijnexperiment in Canada toont een significante toename van 0,47 ton C/ha/jaar in de $0-15 \mathrm{~cm}$-laag wanneer gewasresten worden achtergelaten t.o.v. verwijderde gewasresten (Malhi et al., 2011). Ranaivoson et al. (2017) tonen in een wereldwijde meta-analyse aan dat er jaarlijks tot 1,39 ton $\mathrm{CO}_{2} /$ ha kan worden vastgelegd in de $0-20 \mathrm{~cm}$-laag wanneer 4-5 ton gewasrest per ha wordt achtergelaten. Voor Nederland zijn er nog geen langetermijnexperimenten beschikbaar waarbij er naar het effect van het achterlaten van gewasresten op bodemorganische stof is gekeken. Wel is bekend dat de C/N-ratio van de gewasresten sterke invloed hebben op de koolstofopbouw (Rietberg et al., 2013). Zo hebben de gewasresten van zomertarwe een veel hogere effectieve organischestof-aanvoer $(2250 \mathrm{~kg} / \mathrm{ha})$ ten opzichte van suikerbieten $(375 \mathrm{~kg} / \mathrm{ha})$.

\subsection{Snijmais met strokenfrees}

Bij deze maatregel wordt ervan uitgegaan dat snijmais in rotatie met tijdelijk grasland geteeld wordt in een rotatie van 3 jaar mais en 3 jaar gras. De snijmais kan dan met strokenfrees in tijdelijk grasland worden ingezaaid, waardoor meer gewasresten van het gras behouden blijven. Daarnaast komt er minder zuurstof in de bodem vergeleken met ploegen, waardoor de mineralisatie van organische stof minder snel gaat. Door de rotatie is de maatregel alleen toepasbaar voor het jaar waarin tijdelijk grasland wordt vervangen door mais. In de langetermijnexperimenten van het programma Slim Landgebruik is een positief, maar niet significant effect gemeten voor het toepassen van deze maatregel (Koopmans et al., 2019). In de bovengrond $(0-30 \mathrm{~cm}$ ) is er een effect van 0,29 ton $\mathrm{C} / \mathrm{ha} / \mathrm{jaar}$ gevonden voor zandgronden en 0,28 ton $\mathrm{C} / \mathrm{ha} / \mathrm{jaar}$ voor kleigronden. Het effect op de snijmaisopbrengsten is nog wel onduidelijk. Voor de proef in Lelystad was de opbrengst in de beginfase significant lager in de experimenten waar een strokenfrees gebruikt werd, vergeleken met de experimenten waar geploegd werd, maar in daaropvolgende jaren was de opbrengst hoger vergeleken met de conventionele methode. Deru et al. (2015) hebben op een van de drie proefvelden een significante toename in het organischestofgehalte gemeten, de andere twee proefvelden lieten een positieve, maar geen significante toename zien.

\subsection{Verhogen gewasproductie}

De gewasproductie kan potentieel verhoogd worden door betere rassen, door optimalisatie van irrigatie en bemesting en vermindering van ziekteverwekkers. Een verhoogde gewasproductie resulteert over het algemeen in een hogere opbrengst van gewasresten. Deze verhoging van gewasresten kan dan resulteren in een verhoging van de aanvoer van organische stof naar de bodem en navenante toename in bodem-C-vastlegging. 
Om in te schatten of er in de komende tien jaar een verhoging plaats zou kunnen vinden, is het van belang om de potentiële yield gap vast te stellen. De yield gap staat voor het verschil tussen de huidige behaalde gewasopbrengst en de potentieel hoogst behaalbare gewasopbrengst onder optimale omstandigheden mogelijk voor dit gebied (Foley et al., 2011).

\subsection{Akkerranden}

Akkerranden vallen onder functionele agrobiodiversiteit. Ze worden vooral aangelegd om de populatie van 1) bijen, hommels en andere bloembezoekers, 2) natuurlijke vijanden van insectenplagen (en op de plaagdichtheden in naastgelegen gewassen), 3) vogels op het landbouwbedrijf te vergroten en 4) zoogdieren op het landbouwbedrijf in stand te houden of te verhogen (Alebeek et al., 2015). Bovendien kunnen akkerranden afvloeiing van sediment en nutriënten verminderen en verbeterde gewasbescherming bieden (Bos et al., 2014). Daarnaast gaat het ook om de waardering voor de landbouw en eventuele recreatiemogelijkheden te verhogen. Om deze doelen te bereiken, worden er verschillende soorten akkerranden ingezaaid (Luske et al., 2015) met specifieke mengsels zoals:

- Bermmengsel (traag groeiende grassen)

- Combi: bergmengsel $(20 \%)+$ bloeiend kruidenmengsel $(80 \%)$

- Kruidenmengsel

Akkerranden dienen als bufferzone langs de rand van een perceel en bestaan uit landschappelijk waardevolle beplanting die de biodiversiteit bevordert. Voor het meetellen van akkerranden als onderdeel van de vergroening zijn regels opgesteld, zoals datum van inzaai, minimale periode, de gewassoorten die ingezaaid mogen worden (met name kruidachtingen, granen of gras) en de breedte en lengte van de strook. Verder mogen er geen meststoffen en gewasbeschermingsmiddelen gebruikt worden op de akkerrand.

In Nederland zijn geen studies waarbij het effect van akkerranden op bodemorganische stof is bepaald. Een studie in Argentinië laat zien dat de akkerranden geen effect hebben op bodem organische stof. Ze verklaren dit omdat de akkerranden vaak worden bespoten met herbiciden die goede biomassaopkomst tegengaan en dus minder OS dan verwacht toedienen aan de bodem (d'Acunto et al., 2014). Een studie in Engeland voorziet een verhoging van bodem-C met 0,63 ton $\mathrm{C} / \mathrm{ha} / \mathrm{jaar}$ voor het areaal onder akkerranden. Dit getal is gebaseerd op een verandering van akkerbouw naar permanent grasland. Daarbij tellen ze nog een extra vastlegging van 0,2 ton $\mathrm{C} / \mathrm{ha} / \mathrm{jaar}$ in de bovengrondse biomassa (gebaseerd op permanent grasland). Naast deze extra vastlegging, kan ook de uitstoot van $\mathrm{N}_{2} \mathrm{O}$ worden verlaagd door de aanleg van akkerranden (Falloon et al., 2004). Voor de koolstofvastlegging maakt het dus veel uit of een akkerrand permanent is (gras) of een bloemrijke akkerrand die jaarlijks opnieuw wordt ingezaaid.

\section{$2.9 \quad$ Vogelakkers}

Vogelakkers worden aangelegd om de dichtheid van (veld)muizen in het agrarisch gebied te verhogen. Dit dient ten goede te komen aan (zeldzame) roofvogels, zoals grauwe en blauwe kiekendief en velduil. Een vogelakker is een volveldse, meerjarige maatregel die meestal voor 3 tot 4 jaar wordt aangelegd (Wiersma et al., 2019). In het veld worden stroken met een meerjarig groenvoedergewas (vaak rode klaver op zandgrond en luzerne op kleigrond) afgewisseld met natuurbraakstroken. Dit zijn mengsels van grassen, granen en kruiden. De verdeling qua oppervlak is hierbij ongeveer $70 \%$ groenvoedergewas en 30\% natuurbraak. De stroken met groenvoedergewas worden maximaal 3 à 4 keer per seizoen gemaaid en gebruikt als groenvoer in de veehouderij (Wiersma et al., 2019). Door het drie- of zelfs vierjarige karakter van de vogelakker is het lastig inpasbaar op akkerbouwbedrijven met vooral eenjarige gewassen. Daardoor zal inpassing makkelijker zijn op gemengde en grondgebonden veehouderijbedrijven dan in akkerbouwplannen. Er zijn voor zover bekend nog geen studies beschikbaar waarin de C-vastlegging van vogelakkers met bodem-C-metingen is bepaald. 


\section{$2.10 \quad$ Niet-kerende grondbewerking}

Niet-kerende grondbewerking is, in tegenstelling tot ploegen, een oppervlakkige bewerking van de bodem. Hierbij worden gewasresten alleen oppervlakkig met de bodem vermengd. Het vervangen van ploegen door toepassen van niet-kerende grondbewerking komt ten goede aan het bodemleven en de bodemstructuur, met als resultaat dat oppervlakteafvoer van bodemmateriaal en organische stof en erosie verminderen. Daarnaast wordt er vaak aangenomen dat niet-kerende grondbewerking bijdraagt aan het vastleggen van $\mathrm{CO}_{2}$ in de bodem doordat de afbraak van organische stof lager zal worden en vermindert.

$\mathrm{Er}$ is echter in de wetenschap al langere tijd discussie over de vraag of er ook daadwerkelijk additioneel koolstof wordt vastgelegd als gevolg van introductie en toepassen van niet-kerende grondbewerking of dat er bijvoorbeeld alleen sprake is van verandering in de verdeling van of de locatie/diepte van organische stof in het profiel. Er zijn vele studies uitgevoerd naar het effect van niet-kerende grondbewerking op $\mathrm{CO}_{2}$-vastlegging en het resultaat is niet altijd eenduidig: er worden positieve en negatieve effecten gedocumenteerd.

Om inzicht te krijgen in het effect van niet-kerende grondbewerking op koolstofvastlegging is hier een kort literatuuronderzoek uitgevoerd. Hierbij lag de focus op onderzoeksresultaten verkregen in Nederland of vergelijkbare omstandigheden en klimaat. Er is onderscheid gemaakt naar de bodemlaag waarin het koolstofgehalte is bepaald en of de resultaten in verandering van koolstofvoorraad significant waren of niet. Het resultaat is weergegeven in Figuur 2. 


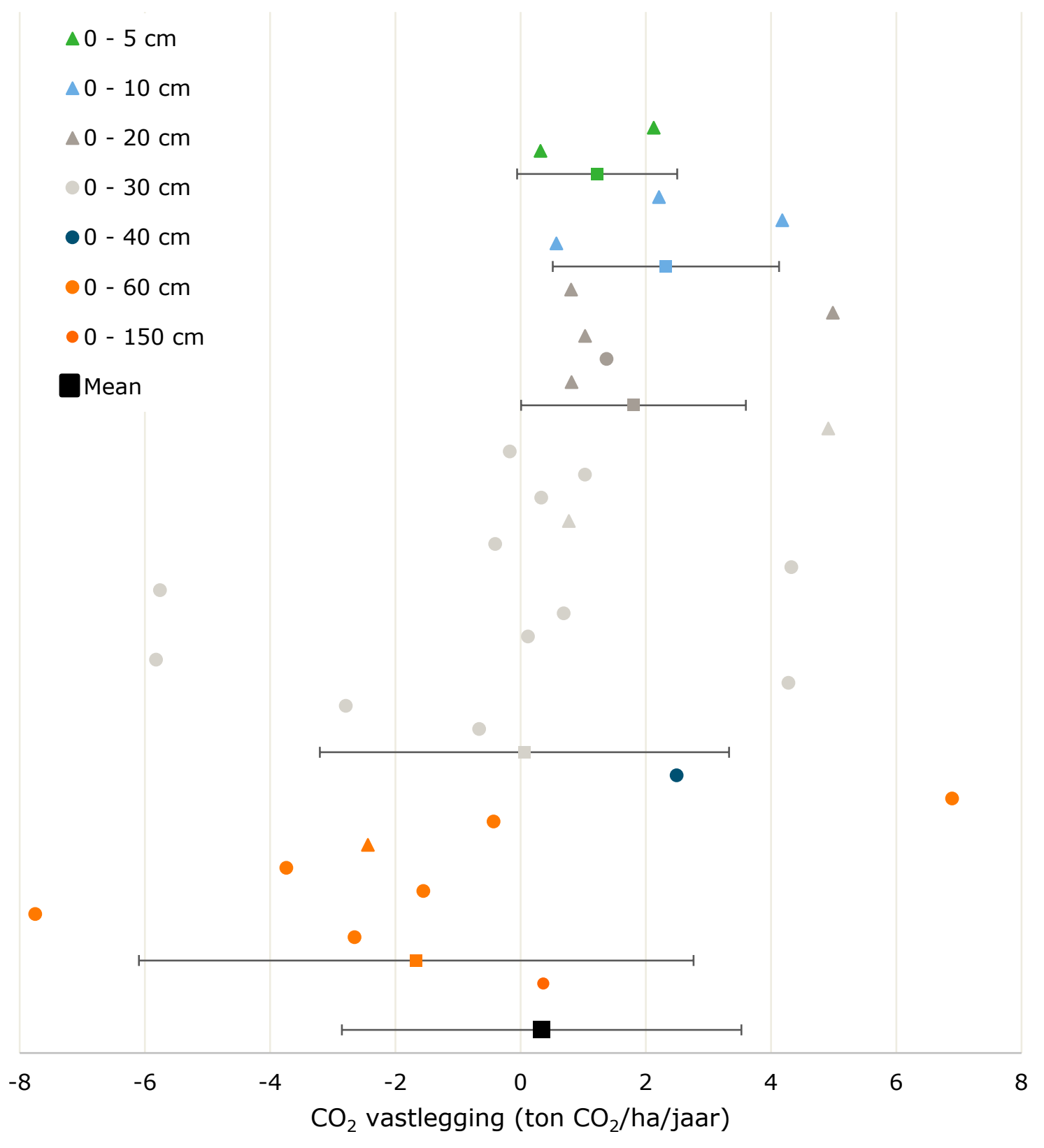

Figuur $2 \mathrm{CO}_{2}$-vastlegging (ton $\mathrm{CO}_{2} / \mathrm{ha} / \mathrm{jaar}$ ) als gevolg van het toepassen van niet-kerende grondbewerking t.o.v. conventioneel ploegen op verschillende bodemdieptes. Driehoekje betekent een significant resultaat $(p<0.05)$ en rondje betekent een niet-significant resultaat. Vierkantje geeft de gemiddelde waarde met de standaard error. De referenties waarop deze figuur is gebaseerd, staan weergegeven in Bijlage 1.

Figuur 2 toont dat in de bodemlaag tot $-20 \mathrm{~cm}$ een voornamelijk significante toename van bodemkoolstof wordt gevonden. De spreiding van de gemiddelden in de lagen 0-5, 0-10 en 0-20 cm is relatief hoog, maar over het algemeen significant verschillend van 0 . In de laag 0-30 cm zijn (op één na) alle resultaten niet significant. De spreiding is groot en het gemiddelde effect ligt rond de nul. Wanneer naar de diepere lagen wordt gekeken, is de trend met name dat het bodemkoolstofgehalte afneemt als gevolg van niet-kerende grondbewerking. Het totale gemiddelde over het gehele bodemprofiel is licht positief, met een vastlegging van 0,34 $\pm 3,10$ ton $\mathrm{CO}_{2} /$ ha/jaar. Zoals te zien in Figuur 2 is de spreiding echter zeer groot. Hieruit concluderen we dat er op basis van deze resultaten niet kan worden vastgesteld dat $\mathrm{CO}_{2}$ wordt vastgelegd als gevolg van vervangen van ploegen door niet-kerende grondbewerking. Het resultaat suggereert dat de koolstof zich in de bovenste laag concentreert, waardoor daar een toename wordt gemeten en in diepere lagen een afname aan de orde is. 
Vergelijkbare resultaten werden ook gevonden door Baker et al. (2006) en Haddaway et al. (2017). Baker et al. (2006) geven aan dat er zelden dieper dan $30 \mathrm{~cm}$ wordt bemonsterd bij een analyse van het effect van grondbewerkingsmaatregelen, ondanks het feit dat wortels vaak een stuk dieper doordringen. De studies opgenomen in de analyse van Baker et al. (2006) tonen geen consistente opbouw van (meer) bodemkoolstof, maar een herverdeling van de koolstof in het bodemprofiel met een hogere bodemkoolstofconcentratie in de bovenste lagen na toepassing van gereduceerde grondbewerking en een hogere bodemkoolstofconcentratie in de diepere lagen na toepassing van conventioneel ploegen. Ook hebben gasmetingen naar de emissie van $\mathrm{CO}_{2}$ geen verschil aangetoond. Haddaway et al. (2017) vinden geen significant verschil tussen gereduceerde grondbewerking en conventionele grondbewerking, noch in de bodemlaag $0-30 \mathrm{~cm}$, noch in het gehele bodemprofiel tot een diepte van $150 \mathrm{~cm}$.

Onze literatuurreview toont geen bewijs dat door het vervangen van ploegen en toepassen van nietkerende grondbewerking er additioneel $\mathrm{CO}_{2}$ wordt vastgelegd. Echter lijken er wel veranderingen in de bodem op te treden, zoals een herverdeling van de concentratie bodemkoolstof (Baker et al., 2006). Deze hogere concentraties stimuleren de biologische activiteit in de bodem en verbeteren daarmee de bodemstructuur, waardoor de bodem beter beschermd is tegen weersextremen en erosie (Haddaway et al., 2017). Ook zou door het toepassen van niet-kerende grondbewerking de stabiliteit van de bodem toenemen, doordat bodemaggregaten minder frequent worden verstoord. Door het niet verstoren van de aggregaten wordt de bodemkoolstof in de aggregaten beter beschermd en kan er minder zuurstof bijkomen. Hierdoor is de kans op oxidatie van koolstof naar $\mathrm{CO}_{2}$ kleiner (Crittenden et al., 2015). Dit zou kunnen leiden tot minder afbraak van bodemkoolstof, waardoor de reeds aanwezige bodemkoolstof behouden blijft. De vraag is wel of dit ook opgaat in intensieve bouwplannen met veel hakvruchten, zoals die in Nederland veel voorkomen.

\subsection{Kruidenrijk grasland}

Kruidenrijk grasland voorziet in meerdere doelen. Het kan de populatie van weidevogels verbeteren. Ook bevat kruidenrijk grasland een betere basis voor gezonde voeding van de koe en dit kan pensverzuring voorkomen en ook de functie van lever en nieren verbeteren (Geerts et al., 2014). Kruidenrijk grasland is over het algemeen een combinatie van grassen, kruiden en vlinderbloemigen (Geerts et al., 2004). Het is te verwachten dat kruidenrijke graslanden, door hun biodiversiteit, een hogere drogestofopbrengst hebben. Dit omdat in een biodivers grasland onder alle omstandigheden wel een soort goed kan produceren (Van Ruijven en Berendse, 2003) en omdat soorten elkaar aan kunnen vullen door complementariteit in nutriëntenopname (van Ruijven en Berendse, 2005). Haughey et al. (2018) toonden aan dat kruidenrijk grasland met klaver beter bestand is tegen en sneller herstelt van droogtestress en droogteschade door diepere beworteling en nichedifferentiatie.

Een studie van Cong et al. (2014) toont aan dat een soortenrijkdom van 8 tegenover 1 op een zandbodem in de regio Wageningen de bodem-C-voorraad verhoogde met 2 ton C/ha/jaar. deze studie bevatte geen vlinderbloemige soorten, alleen diversiteit in grassen. Een ander onderzoek (op een zandige bodem in Engeland) toonde juist aan dat soortenrijkdom geen bodem-C-verhoging veroorzaakte (De Deyn et al., 2009). Een gras-diversiteitsexperiment in Jena (Duitsland) toont aan dat een hogere biodiversiteit de bodem-C-opslag kan verhogen. In deze studie wordt geconcludeerd dat een biodivers grasland een grotere (wortel exudaat-)C-input heeft en een beter microklimaat voor micro-organismen. Dit leidt tot een hogere diversiteit en activiteit van microben die meer organische stof omzetten, wat kan leiden tot verhoging van de C-voorraad (Lange et al., 2015). In Nederland loopt sinds 2018 ook een experiment met kruidenrijk grasland waar gekeken wordt naar het effect op bodem-C. De resultaten van dit experiment zullen in het kader van het Slim Landgebruik-programma worden geanalyseerd, maar zijn nog niet beschikbaar.

Twee meta-analyses (met studies wereldwijd) gaven aan dat een hogere biodiversiteit in graslanden gemiddeld leidde tot een kleine, significante verhoging van de bodem-C-voorraad (Xu et al., 2020; Wang et al., 2020) en dat het effect op bodem-C-voorraad toeneemt over de tijd (Wang et al., 2020). Op basis van het literatuuronderzoek concluderen we dat gemiddeld genomen kruidenrijke graslanden waarschijnlijk een verhoging in bodem-C veroorzaken, ook al is er behoorlijke variatie in het effect op 
bodem-C-opslag. Bij gebrek aan specifieke Nederlandse resultaten en de beperkte internationale data, hebben we de potentie voor C-vastlegging van deze maatregel voorlopig echter nog niet gekwantificeerd.

\subsection{Diep wortelende gewassen}

Wanneer er diep wortelende gewassen, zoals bepaalde grassen, worden geteeld, kunnen het grondwater en de beschikbare nutriënten (zoals $\mathrm{N}$ ) in diepere bodemlagen beter worden benut (Van Eekeren et al., 2011). Zo wordt uitspoeling van nitraat voorkomen en kan diepere beworteling ook de bodemstructuur verbeteren en een rol spelen in de organischestof-opbouw (Van Eekeren et al., 2011). Uit recente studies is gebleken dat wortels een belangrijkere rol hebben t.o.v. bovengrondse biomassa met betrekking tot bodem-C-opslag. De studie van Rasse et al. (2005) liet zien dat wortels gemiddeld 2,4 keer zoveel $C$ vastleggen ten opzichte van bovengrondse biomassa per eenheid biomassa (of C). Dit komt doordat wortelexudaten makkelijk gestabiliseerd kunnen worden aan minerale oppervlakken naast de stabilisatiemechanismen van inherent recalcitrant materiaal en stabilisatie in aggregaten (Rasse et al., 2005). Een recentere studie liet zien dat de gemiddelde humificatiecoëfficiënt van wortels 0,39 is; dit is ongeveer 2,3 keer zo hoog als de humificatiecoëfficiënt voor bovengronds plantenmateriaal (Kätterer et al., 2011).

Het is aannemelijk dat diep wortelende grassen, zeker als ook de totale worteldichtheid of biomassa toeneemt, een belangrijke rol spelen in de vastlegging van bodem C. Deze potentie wordt aangestipt in een review paper door Kell (2011), waar wordt aangegeven dat wortels die dieper dan 1 meter wortelen extra kunnen bijdragen aan C-vastlegging in de bodem. Er zijn nog geen recente studies die kunnen aangeven of diep wortelende grassen inderdaad de bodem-C-vastlegging verhogen (Poirier et al., 2018; Whitehead, 2020). Er is wel bewijs dat $C$ over het algemeen stabieler is en dus kan bijdragen aan C-vastlegging in de bodem (Thorup-Kristensen et al., 2020). Maar het is niet duidelijk of dit ook het geval is wanneer wortels ook in deze diepere lagen aanwezig zijn, en dus de nutriëntenbeschikbaarheid, waterhuishouding, structuur et cetera beïnvloeden (Thorup-Kristensen et al., 2020). Bij gebrek aan Nederlandse resultaten en de beperkte internationale data, hebben we de potentie voor C-vastlegging van deze maatregel voorlopig nog niet gekwantificeerd. Daarnaast is het de vraag hoe om te gaan met C-vastlegging in de ondergrond. Voor de internationale emissierapportages wordt tot nu toe alleen een verandering van de C-voorraad in de bovenste $30 \mathrm{~cm}$ gerapporteerd en met het RothC-model kan de C-dynamiek alleen voor de bovengrond worden gemodelleerd. 


\section{$3 \quad$ Modellering bodem-C-vastlegging}

\subsection{Methodologie}

\subsubsection{Aanpak}

Voor het modelleren van koolstofvastlegging in bodems zijn in de loop der jaren een hele reeks modellen ontwikkeld, die verschillen in mate van complexiteit. In Lesschen et al. (2020) is een overzicht gemaakt van modellen die mogelijk toepasbaar zijn voor gebruik in de Nederlandse landbouwpraktijk. Voor het berekenen van de potentiële C-vastlegging in landbouwbodems voor de verschillende bodem-C-maatregelen, hebben we in deze studie gekozen voor het RothC-model vanwege de volgende redenen:

- Het model is wetenschappelijk verantwoord en beschreven in meerdere peer-reviewed publicaties (o.a. Coleman et al., 1997; Smith et al., 1997; Byrne and Kiely, 2009).

- RothC is internationaal al veel toegepast en gaat ook gebruikt worden op mondiale schaal voor het FAO-GSOCSeq-initiatief en op Europese schaal in het EJP Soil project CarboSeq.

- RothC is een relatief simpel model en vereist een beperkte set aan invoerdata, die op nationale schaal ook beschikbaar is.

- Het model is toepasbaar voor de Nederlandse klimaatomstandigheden en geschikt voor zowel akkerland als grasland. Het model is namelijk gekalibreerd met de data uit de Rothamsted lange termijn-veldexperimenten (Coleman and Jenkinson, 1996).

- Het model is al eerder op nationale schaal toegepast in de studie van Conijn en Lesschen (2015) voor het berekenen van de bodem-C-balans en het is de bedoeling om dit model ook te gebruiken voor de nationale emissieregistratie voor het berekenen van de verandering in koolstofvoorraad voor grasland en akkerland.

Het RothC-model is ontwikkeld voor het simuleren van één perceel, maar de rekenregels zijn in principe schaalonafhankelijk, waardoor het model ook op grotere schaal kan worden toegepast. Voor toepassing op nationale schaal voor Nederland is het model daarom ingebouwd in het MITERRA-NLmodel. MITERRA-NL is een emissiemodel voor de Nederlandse landbouw dat rekent op postcode 4-niveau (Lesschen et al., 2011). Op basis van statistische data, o.a. gewasarealen uit Basis Registratie Percelen (BRP), dieraantallen en gewasopbrengst (gemiddelde van 2016-2018) en kunstmestconsumptie uit CBS, berekent het model MITERRA-NL de verdeling van kunstmest en dierlijke mest en de bijbehorende emissies van lachgas en andere $\mathrm{N}$-componenten.

RothC wordt gebruikt om op postcode 4-niveau per gewas de koolstofbalans te berekenen op basis van gegevens over bemesting, gewasopbrengst en bodemgegevens die uit MITERRA-NL worden afgeleid. Het basisjaar waarvoor de berekeningen zijn uitgevoerd, is 2017, aangezien voor dit jaar de gewasarealen uit BRP beschikbaar waren in het model. De berekening voor 2017 is de baseline, en iedere maatregel is daarna apart doorgerekend t.o.v. deze baseline.

\subsubsection{RothC-modelbeschrijving}

Het RothC-model is een dynamisch model om de koolstofdynamiek in minerale bodems te simuleren. Het model is gekalibreerd op langetermijnexperimenten uit Rothamsted Research station in het Verenigd Koninkrijk (Coleman and Jenkinson, 1996). Het model wordt internationaal veel toegepast en is veelvuldig gedocumenteerd (o.a. Coleman et al., 1997; Smith et al., 1997; Byrne and Kiely, 2009). Het model houdt rekening met de effecten van bodemtype, temperatuur, vochtgehalte en bodembedekking op de afbraak van organische koolstof. Het model gebruikt maandelijkse tijdstappen om veranderingen in de organische koolstofvoorraad te berekenen op een tijdschaal van één jaar tot eeuwen. In deze studie is RothC-versie 26.3 gebruikt, zoals beschreven in Coleman en Jenkinson (2014). 
In het RothC-model wordt de koolstof verdeeld over vier actieve compartimenten en een compartiment met inerte organische stof (Figuur 3). De vier actieve compartimenten/pools zijn respectievelijk afbreekbaar plantmateriaal (DPM), resistent plantmateriaal (RPM), microbiële biomassa (BIO) en humus (HUM). Elk van deze vier pools heeft zijn eigen specifieke afbraakcoëfficiënt (de afbraak is een fractie van de aanwezige hoeveelheid organische stof). In de inerte organische stof vindt geen afbraak meer plaats. De afbraak wordt beschreven als een zogeheten eerste-orde-proces. De afbraakconstanten zijn 10 voor de DPM-pool, 0,3 voor de RPM-pool, 0,66 voor de BIO-pool en 0,02 voor de HUM-pool. Dit betekent bijvoorbeeld voor de HUM-pool dat gemiddeld $2 \%$ van de organische koolstof in die pool per jaar afbreekt, terwijl voor de RPM-pool 30\% van de koolstof wordt afgebroken. De afbraakconstante van 10 geeft aan dat alle materie ruim binnen de termijn van één jaar wordt afgebroken. Deze afbraakcoëfficiënten worden beïnvloed door textuur, temperatuur, vocht en bodembedekking en zijn dus plaats-specifiek. De C-aanvoer in gewasresten wordt verdeeld over de DPM- en RPM-pool in de verhouding 0,59:0,41 en de C-aanvoer in organische mest wordt verdeeld over de DPM-, RPM- en HUM-pool in de verhouding 0,49:0,49:0,02.

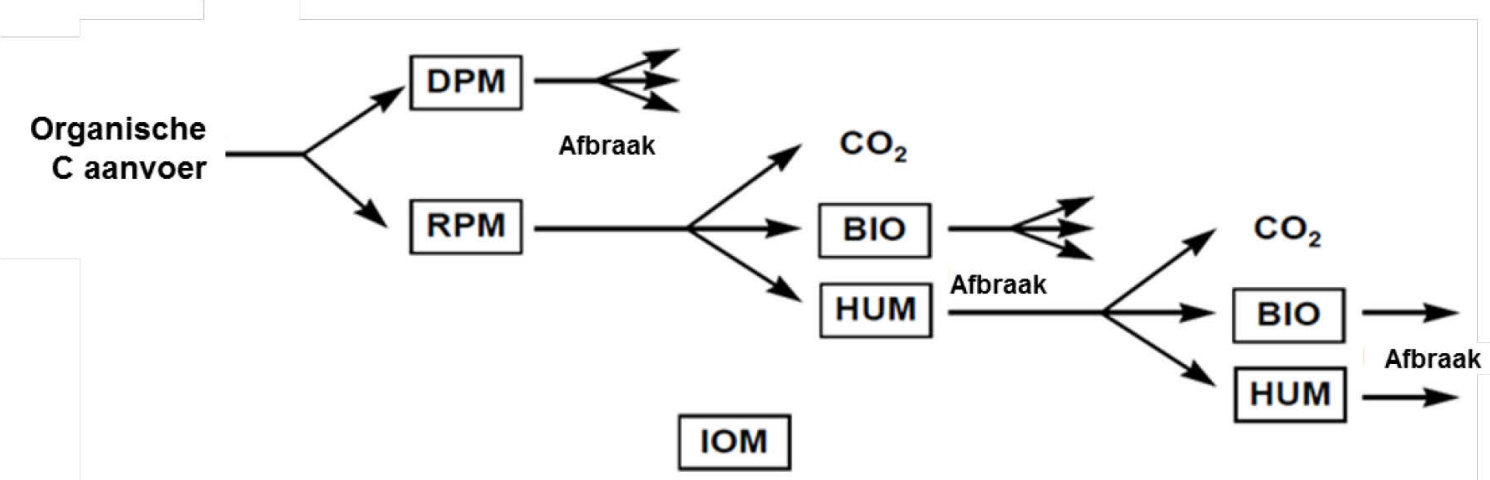

RPM : Resistent Plant Materiaal
DPM : Afbreekbaar Plant Materiaal
BIO : Microbiele biomassa
HUM : Humus

IOM : Inert organische stof

Figuur 3 Schematisch overzicht van de koolstofcompartimenten in het RothC-model.

Voor deze studie is gerekend met een bodemdiepte van $25 \mathrm{~cm}$; dit is de laag waar de meeste aanvoer en afbraak van koolstof in de bodem plaatsvindt. Deze diepte past beter bij de gemiddelde ploegdiepte, de bodembemonstering in de praktijk ( $25 \mathrm{~cm}$ voor akkerbouw en $10 \mathrm{~cm}$ voor grasland) en de standaarddiepte waar RothC mee rekent $(23 \mathrm{~cm})$. Voor de emissieregistratie wordt echter gerapporteerd over de bodem-C-veranderingen in de laag $0-30 \mathrm{~cm}$. Op basis van testsimulaties bleek dat het rekenen met $30 \mathrm{~cm}$ bodemdiepte leidt tot een overschatting van de bodem-C-afbraak en dat $25 \mathrm{~cm}$ beter overeenkomt met de metingen. Uiteindelijk heeft de keuze voor de bodemdiepte met name effect op de absolute uitkomst van de bodem-C-balans en veel minder effect op de doorrekening van de maatregelen, aangezien deze worden vergeleken met de baseline.

\subsubsection{Invoer data}

Het RothC-model heeft de volgende invoergegevens nodig: klimaatgegevens op maandbasis (neerslag, verdamping en gemiddelde luchttemperatuur), organische koolstofgehalte en kleigehalte van de bodem, de mate van bodembedekking door een gewas, de aanvoer van plantenresten, de aanvoer van organische meststoffen en de bodemdiepte waarmee wordt gerekend. In Lesschen et al. (2020) staat een gevoeligheidsanalyse beschreven voor een aantal van de invoerparameters van het RothC-model. Hieruit bleek dat met name het gekozen weerjaar een groot effect heeft op de berekende koolstofbalans. 


\section{Klimaatgegevens}

Voor de klimaatgegevens hebben we gebruikgemaakt van de dataset gebaseerd op metingen van het KNMI, met maandelijkse klimaatdata per KNMI-zone (15 regio's in Nederland, referentie) voor de periode 1983-2017. De KNMI-gegevens voor verdamping zijn gebaseerd op de referentiegewasverdamping volgens de formule van Makkink (Makkink, 1957). De referentiegewasverdamping is de hoeveelheid water die verdampt uit een grasveld dat goed voorzien is van water en nutriënten. Het RothC-model maakt echter gebruik van openwaterverdamping. Hiervoor wordt de Makkinkverdamping vermenigvuldigd met 1,25 (Feddes et al., 2003). Voor de uiteindelijke bodem-Cberekeningen is het weerjaar 2017 gebruikt; uit een testsimulatie voor de jaren 2008-2017 bleek dat jaar qua temperatuur en neerslag het meest gemiddelde jaar uit de reeks.

\section{Bodemgegevens}

Een van de belangrijkste invoergegevens voor RothC is het huidig koolstofgehalte van de bodem. Hiervoor is gebruikgemaakt van de CC-NL-meetcampagne (Van Tol-Leenders et al., 2019), die als onderdeel van het Slim Landgebruik-programma is uitgevoerd in 2018/2019. Deze meetcampagne is een bemonstering op 1152 locaties die eerder in de periode 1995-2002 zijn bemonsterd als onderdeel van de LSK-steekproef. Op elke locatie zijn o.a. het OS-gehalte en C-gehalte van de bodem bepaald voor de laag 0-30 cm en $30-100 \mathrm{~cm}$.

De oorspronkelijke stratificatie van de LSK-steekproef is gebaseerd op bodemtype en grondwatertrap. Daarom is het niet direct mogelijk om onderscheid naar landgebruik te maken, terwijl landgebruik en verandering van landgebruik wel belangrijke, sturende factoren zijn voor het koolstofgehalte van de bodem. Voor deze studie is daarom een nieuwe classificatie gemaakt van de CC-NL-waarnemingen op basis van bodemtype (zandgrond, eerdgrond, kleigrond, lössgrond, moerige grond en veengrond), landgebruik (akkerland en grasland) en regio (Noord: Friesland, Groningen, Drenthe en Overijssel; West: Noord-Holland, Zuid-Holland, Zeeland en Flevoland; Zuidoost: Gelderland, Utrecht, NoordBrabant en Limburg). Alleen voor combinaties met minimaal vijf locaties is een gemiddelde berekend, zie Figuur 4. De 1:50.000-bodemkaart van Nederland is daarna gebruikt voor het berekenen van het gemiddelde C-gehalte van de minerale bodems per postcode 4-gebied voor akkerland en grasland.

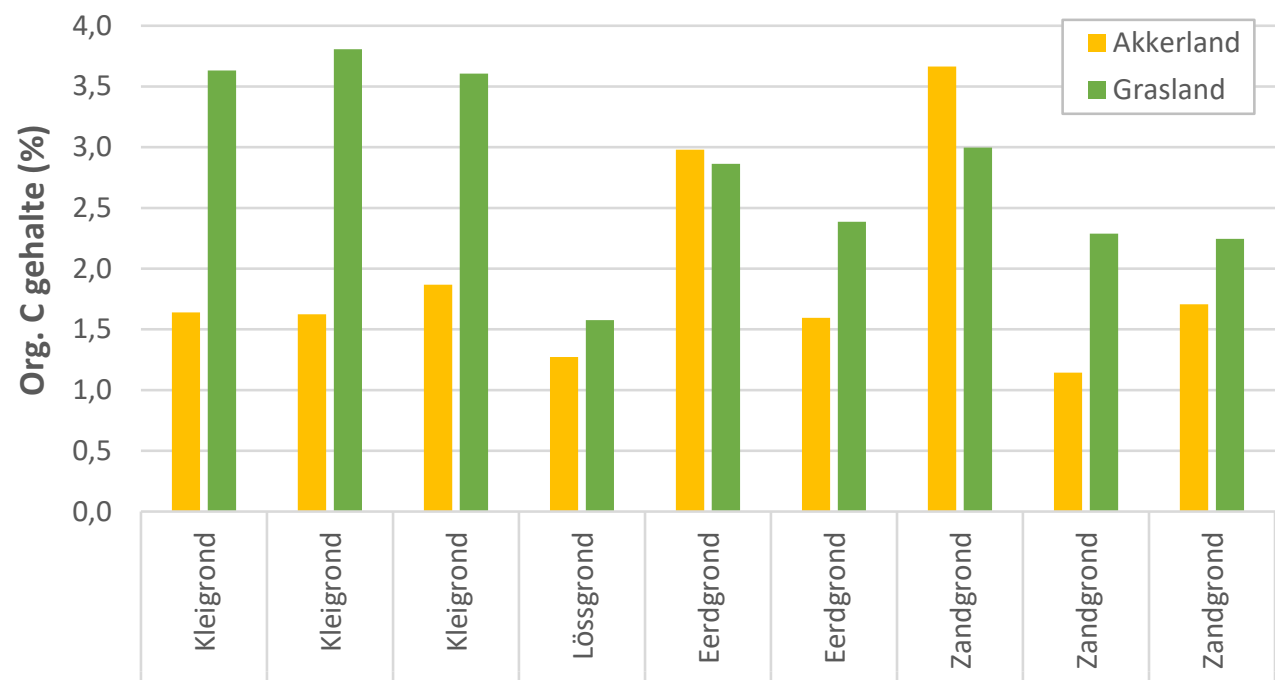

Figuur 4 Organisch C-gehalte per bodemtype, landgebruik en regio, gebaseerd op CC-NLmeetcampagne.

Voor kleigehalte is gebruikgemaakt van de Bodemfysische eenhedenkaart (BOFEK2020). Dit is een GIS-bestand met daarin de ruimtelijke verbreiding van bodemfysische eenheden, gebieden met overeenkomstige bodemopbouw en overeenkomstig hydrologisch gedrag op basis van acht fysische kengetallen. Voor het omrekenen van het koolstofgehalte naar de koolstofvoorraad is het nodig om de dichtheid van de bodem te weten. In de CC-NL-survey en LSK-steekproef is dichtheid niet standaard gemeten. Daarom maken we gebruik van zogenaamde pedo-transferfuncties waarmee de dichtheid berekend kan worden op basis van andere bodemeigenschappen, in dit geval het 
organischestofgehalte en de bodemtextuur. Effecten van bodemverdichting worden echter in deze formules niet meegenomen. Voor kleigronden wordt de formule van Wösten (2001) gebruikt en voor zandgronden die van Hoekstra en Poelman (1982) met gehaltes in procenten.

$$
\begin{gathered}
\text { Dichtheid }_{\mathrm{klei}}=\begin{array}{c}
1 /\left(0.6117+(0.003601 * \text { kleigehalte })+\left(0.002172 *(\text { OS-gehalte })^{2}\right)+\right. \\
(0.01715 * \log (\text { OS-gehalte }))
\end{array} \\
\text { Dichtheid }_{\text {zand }}=1 /(0.667+(0.021 * \text { OS-gehalte }))
\end{gathered}
$$

\section{Aanvoer C uit gewasresten}

De aanvoer van koolstof in gewasresten is vaak de grootste bron van koolstofaanvoer naar de bodem. Data over deze aanvoer zijn echter maar beperkt beschikbaar en wordt vaak indirect bepaald uit gegevens over gewasopbrengst of via kengetallen per gewas. Het meten en vaststellen van deze Caanvoer naar de bodem is lastig, met name voor permanente gewassen zoals gras. Voor deze studie wordt voor een deel van de gewassen een standaard C-aanvoer per ha verondersteld, onafhankelijk van de gewasopbrengst, gebaseerd op de kengetallen voor effectieve organische stof of op basis van literatuurgegevens (Wenum et al., 2013). Voor grasland is er het hele jaar door afbraak van plantenresten en groei van wortels en nieuwe spruiten. In Lesschen et al. (2020) is voor grasland deze aanvoer bepaald door voor een aantal langetermijnexperimenten terug te rekenen wat de aanvoer van $\mathrm{C}$ moet zijn geweest om tot de geobserveerde verandering in bodem-C-voorraad te komen. Deze berekende koolstofaanvoer varieert sterk, maar is gemiddeld voor blijvend grasland 5,1 ton C/ha/jaar. Een verdere specificatie naar bijvoorbeeld grasopbrengst bleek niet mogelijk, aangezien de bovengrondse productie bij gras vaak omgekeerd evenredig is met de ondergrondse biomassa.

Voor andere gewassen, die een duidelijke relatie tussen gewasopbrengst en gewasresten hebben, wordt gebruikgemaakt van de harvest index, een coëfficiënt die aangeeft wat het percentage oogstbaar product is van de totale gewasproductie. Een recente paper door García-Condado et al. (2019) heeft voor verschillende gewassen functies afgeleid om gewasrestopbrengst te schatten, afhankelijk van de gewasopbrengst. Deze empirische relaties hebben nog wel een behoorlijke onzekerheid door verschillen in irrigatie, bemesting en verschillende variëteiten (Camia et al., 2018; García-Condado et al., 2019), maar geven een betere schatting van de gewasopbrengst dan een standaard kengetal. De functies uit de paper van García-Condado et al. (2019) zijn gebruikt voor het schatten van de gewasresten van graangewassen en koolzaad. Aangezien deze functies alleen de bovengrondse biomassa weergeven, is ook nog een schatting nodig van de ondergronds gewasresten. Voor de C-aanvoer uit wortels en wortelexudaten (uitscheidingsproducten van wortels) is aangenomen dat dit $25 \%$ van de totale door de plant vastgelegde $C$ is (Taghizadeh-Toosi et al., 2014). Voor de graangewassen is ook nog bepaald welk deel van de bovengrondse gewasresten stro is en welk deel stoppel, aangezien stro ook deels van het veld wordt verwijderd. Hiervoor is een verhouding strostoppel van 55:45 gebruikt (Powlson et al., 2011; Panoutsou and Labalette, 2007). De gemiddelde aanvoer van $\mathrm{C}$ uit gewasresten is voor de baseline weergegeven in Figuur 7.

\section{Aanvoer $C$ uit organische meststoffen}

Voor de aanvoer van koolstof met organische mest wordt gebruikgemaakt van de stikstofstromen in het MITERRA-NL-model (Lesschen et al., 2011). In MITERRA-NL heeft elke diercategorie een excretiefactor die de totale hoeveelheid $\mathrm{N}$ in dierlijke mest bepaalt. Allereerst wordt een deel van de mest verwerkt of geëxporteerd buiten de landbouw; deze hoeveelheid is afgeleid uit de CBSstatistieken. De resterende hoeveelheid mest wordt daarna verdeeld over de verschillende gewassen op basis van de bemestingsnormen voor stikstof en fosfaat en de acceptatiegraad voor dierlijke mest. Via C/N-ratio's van de verschillende mestsoorten, gebaseerd op het Handboek bodem en bemesting, wordt de totale hoeveelheid $\mathrm{C}$ berekend die per gewas en postcodegebied wordt toegediend. De $\mathrm{C} / \mathrm{N}-$ ratio is hoger voor vaste mest dan voor drijfmest en hoger voor rundermest dan voor varkensmest.

Naast dierlijke mest wordt ook de C-aanvoer uit compost meegenomen. Op basis van statistieken van de Branchevereniging Organische Reststoffen (BVOR) is bekend hoeveel compost er wordt geproduceerd in Nederland en welk aandeel wordt afgezet binnen de landbouw. Voor 2017 ging het om 500 kton gft-compost en 1300 kton groencompost, waarvan respectievelijk $75 \%$ en $50 \%$ binnen de landbouw wordt afgezet. Aangezien er geen statistieken zijn over het gebruik van compost binnen 
de verschillende teelten, is aangenomen dat de compost evenredig over bouwland wordt toegepast; dit resulteert in een gemiddelde toediening van $168 \mathrm{~kg} \mathrm{C} / \mathrm{ha} / \mathrm{jaar}$.

Aanvoer C uit groenbemesters/vanggewassen

Een laatste bron van C-aanvoer naar de bodem is van de plantenresten van groenbemesters/vanggewassen. Voor snijmais op zand of lössgrond is het al verplicht om een vanggewas te telen na de oogst. Ook voor andere teelten wordt al gebruikgemaakt van groenbemesters in het kader van de verplichting voor het ecologische aandachtsgebied als onderdeel van de GLB-vergroeningseisen. In 2017 werd op 266 duizend ha een vanggewas/groenbemester toegepast; hiervan was het merendeel ingezaaid met gras, gevolgd door bladrammenas en gele mosterd (Tabel 2). Het aandeel groenbemesters dat na de oogst ingezaaid wordt, is het hoogst in delen van Noord-Holland, Zeeland en Flevoland (Figuur 5). In het oosten van Overijssel en in het rivierengebied van Gelderland worden groenbemesters het minst toegepast.

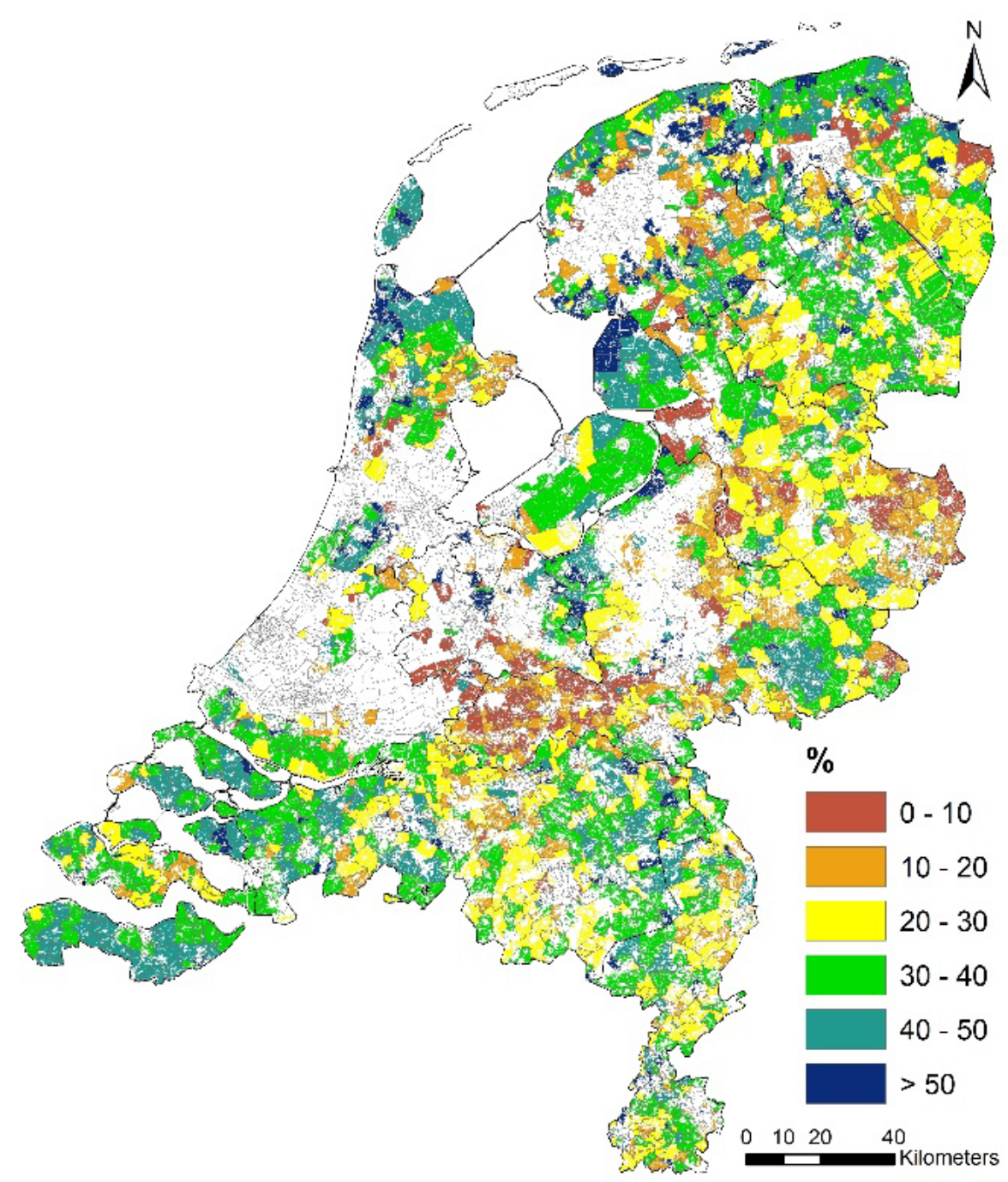

Figuur $5 \quad$ Huidige toepassing van groenbemesters als percentage van het totale areaal bouwland. 
Tabel 2 Areaal ingezaaid met groenbemesters in 2017 (gegevens BRP) en de gemiddelde C aanvoer per groenbemester.

\begin{tabular}{lll} 
Groenbemester & Areaal (ha) & C aanvoer (ton C/ha) \\
Bladrammenas & 73509 & 2,2 \\
\hline Engels raaigras & 30004 & 1,4 \\
\hline Facelia & 4403 & 0,7 \\
\hline Gele mosterd & 49948 & 1,3 \\
\hline Grasland, tijdelijk & 18485 & 1,4 \\
\hline Italiaans raaigras & 52755 & 1,4 \\
\hline Japanse haver & 25694 & 1,6 \\
\hline Overig & 8687 & 1,8 \\
\hline Rietzwenkgras, anders dan voor industriegras & 3052 & 1,7 \\
\hline Groenbemester totaal & 266537 & \\
\hline
\end{tabular}

\subsection{Baseline}

Voor het jaar 2017 is een berekening gemaakt van de bodemkoolstofvoorraad, de gemiddelde aanvoer van koolstof naar de bodem en de koolstofbalans voor de huidige situatie onder akkerland en grasland; de zogenaamde baseline. Het effect van de maatregelen wordt afgezet tegen deze baseline. Het noordoosten van Nederland heeft over het algemeen de hoogste koolstofvoorraden en het zuiden en Flevoland de laagste (Figuur 6). Deze laatste regio's zijn ook de gebieden met de laagste aanvoer van koolstof. De berekende C-balans laat zien dat in de gebieden met veel grasland (Friesland, Gelderland) de balans positief is, terwijl veel akkerbouwgebieden een negatieve C-balans hebben. Delen van Groningen en Drenthe hebben een behoorlijk negatieve C-balans, wat wordt veroorzaakt door de hogere C-gehalten van die bodems, terwijl de aanvoer van C in de akkerbouwgebieden (met name Veenkoloniën) beperkt is. Doordat veel veen- en moerige gronden in dit gebied zijn verdwenen en restanten door het zand zijn geploegd, zijn de bodem-OS-gehalten hier hoger dan je zou verwachten op basis van het landgebruik. Mogelijk dat het model de afbraak van deze oude veenresten ook overschat, omdat het model niet ontwikkeld is voor organische bodems.

De gemiddelde C-aanvoer op grasland is $6400 \mathrm{~kg} \mathrm{C} / \mathrm{ha}$, terwijl dit voor akkerland een stuk lager is met $3600 \mathrm{~kg} \mathrm{C} / \mathrm{ha}$. Echter tussen gewassen zijn er grote verschillen, variërend van $7200 \mathrm{~kg} \mathrm{C/ha}$ voor korrelmais, waarbij is aangenomen dat alle gewasresten op het land achterblijven, tot $1700 \mathrm{~kg} \mathrm{C} / \mathrm{ha}$ voor uien. Het merendeel (70-75\%) van de C-aanvoer komt uit gewasresten en groenbemesters, terwijl C uit dierlijke mest en compost een kleiner aandeel heeft (Figuur 10). De afbreekbaarheid van de gewasresten is echter wel hoger vergeleken met dierlijke mest en compost.
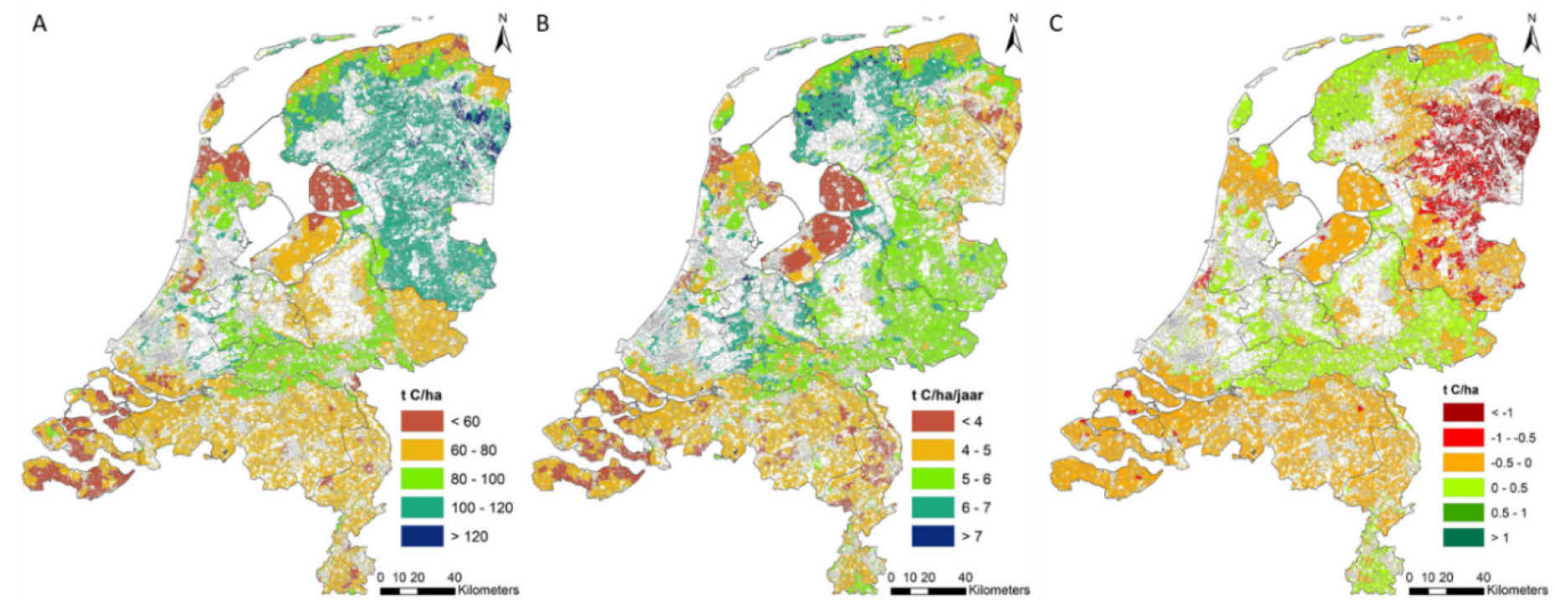

Figuur 6 Gemiddelde koolstofvoorraad in minerale landbouwbodem $(A)$, de aanvoer van koolstof naar de bodem $(B)$ en de ruimtelijke verdeling van de bodem-C-balans (C). 


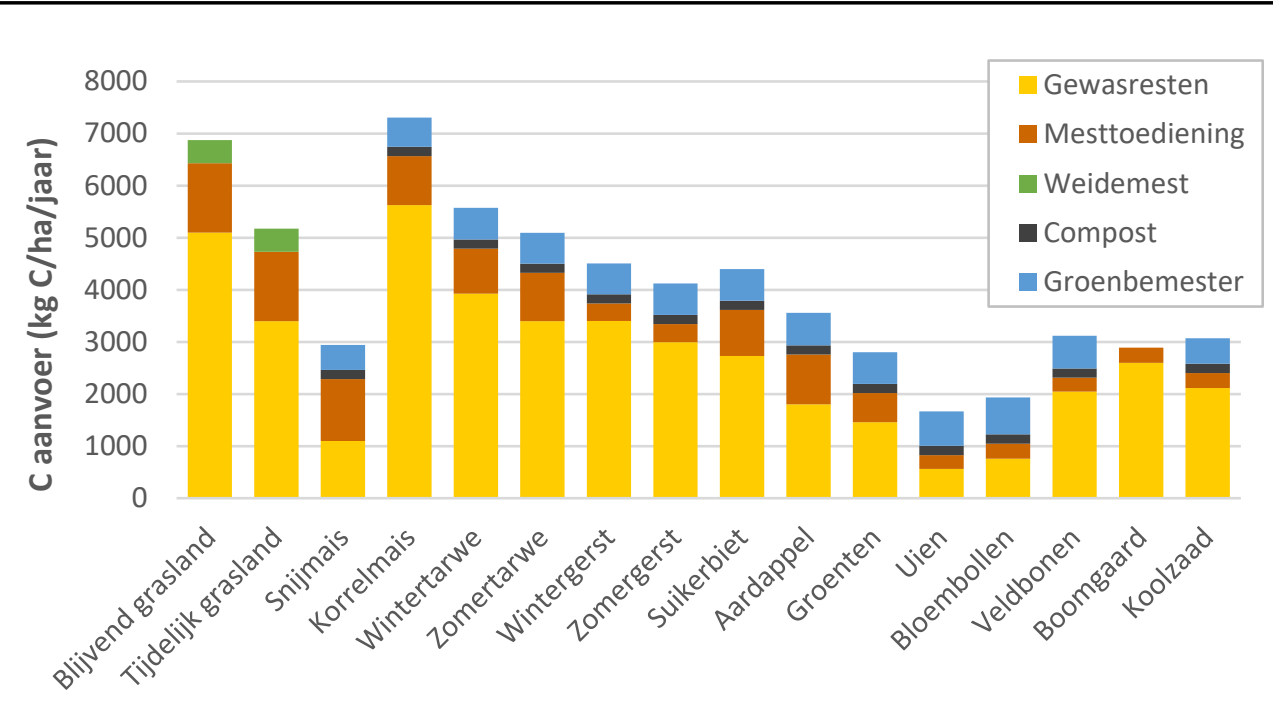

Figuur 7 Gemiddelde C-aanvoer naar de bodem voor grasland en belangrijkste akkerbouwgewassen.

\subsection{Parametrisatie van maatregelen}

\subsubsection{Verhogen aandeel rustgewassen in rotatie}

Er zijn veel verschillende mogelijkheden om te komen tot een gewasrotatie die extra koolstofvastlegging bevordert. Op hoofdlijnen komt het neer op extensivering van het bouwplan, met minder intensieve gewassen (hak-/rooivruchten zoals aardappels, suikerbieten, bollen en uien) en meer rustgewassen. Voor de berekening van deze maatregel zijn rustgewassen gedefinieerd als graangewassen. Tijdelijk grasland kan ook een rustgewas in een akkerbouw rotatie zijn, maar uit de BRP-data is niet af te leiden of het huidige, tijdelijke grasland onderdeel is van de akkerbouw of van de (melk)veehouderij. In lijn met Koopmans et al. (2020) is deze maatregel ingevuld door het aandeel rustgewassen in de gewasrotatie te verhogen naar minimaal 50\%. Overige akkerbouwgewassen zoals groenten en eiwitgewassen zijn in de berekening niet meegenomen.

In het model worden intensieve gewassen vervangen door wintertarwe dat nu het meest voorkomende graangewas in Nederland is. Het aandeel intensieve gewassen wordt dus per postcode 4-gebied teruggebracht naar $50 \%$ en vervangen door wintertarwe. In gebieden waar het aandeel rustgewassen al $50 \%$ of hoger is, zal geen verandering plaatsvinden. De implementatie van deze maatregel op lokaal niveau leidt op provinciaal niveau tot een afname in het aandeel intensieve gewassen in de gewasrotatie (Figuur 8). In Drenthe, Friesland, Flevoland, Noord-Brabant, Noord-Holland en Overijssel ligt het aandeel intensieve gewassen in de rotatie op of zelfs boven de $70 \%$. Vooral in deze gebieden kan het verhogen van het aandeel rustgewassen bijdragen aan koolstofvastlegging. In Groningen, Limburg, Zeeland en Gelderland wordt voor ongeveer $50 \%$ aan rustgewassen in de rotatie opgenomen. We nemen aan dat deze maatregel kan worden toegepast voor alle gewassen en rotaties in de akkerbouw. Gras, snijmais, meerjarige gewassen en braakliggend land worden buiten beschouwing gelaten. 


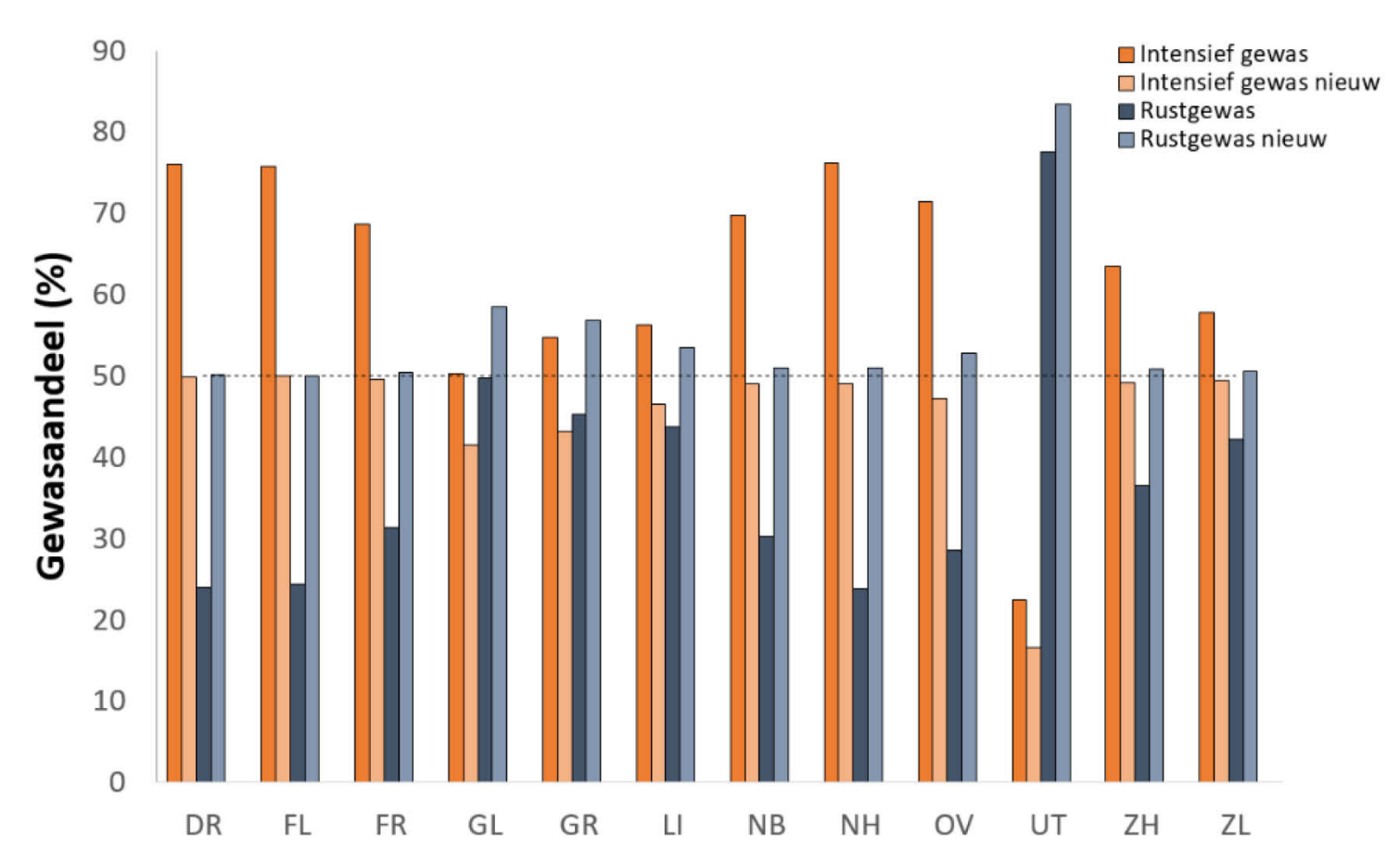

Figur 8 Gemiddeld aandeel rust- en intensieve gewassen per provincie voor de baseline (2017) en de situatie na het implementeren van de maatregel verhogen aandeel rustgewassen (aangeduid met 'nieuw'), gebaseerd op gegevens uit de Basisregistratie Percelen van 2017. De stippenlijn is de $50 \%-l i j n$.

\subsubsection{Verhogen aandeel blijvend grasland}

In deze studie wordt het verhogen van het aandeel blijvend grasland op twee manieren gemodelleerd: 1) optimaal landgebruik volgens de 60-20-20-regel voor de melkveehouderij (Van Eekeren et al., 2007) en 2) grondgebonden melkveehouderij met meer grasland.

De eerste maatregel is gebaseerd op Van Eekeren et al. (2007), die de 60-20-20-regel voorstelt voor de melkveehouderij met snijmais. Dit betekent dat $60 \%$ van het land uit blijvend grasland bestaat, $20 \%$ snijmais en $20 \%$ uit tijdelijk grasland, liefst met klaver, zodat ook de kunstmestgift kan worden verminderd. Dit zou zowel vanuit milieu- als vanuit economisch oogpunt een optimale verdeling zijn.

De potentiële opbouw van organische stof bij een vruchtwisseling van 3 jaar mais en 3 jaar gras zit tussen permanent grasland en permanent bouwland in (Van Eekeren et al., 2007). Dit sluit ook aan bij de derogatie, waarin de eis van $80 \%$ grasland is opgenomen. Het huidige aandeel blijvend grasland, tijdelijk grasland en mais (Figuur 9) laat zien dat vooral in Flevoland, Noord-Brabant, Limburg en Zeeland het aandeel blijvend grasland omhoog kan.

De maatregel is op lokaal schaalniveau (postcode 4-niveau) doorgevoerd, aangezien er slechts enkele postcodegebieden zijn gevonden waar geen tijdelijk grasland is, terwijl er wel mais geteeld wordt. Voor de regio's met minder dan 60\% blijvend grasland (als percentage van het totaal van blijvend grasland, tijdelijk grasland en snijmais) wordt het areaal tijdelijk grasland en snijmais vervangen door blijvend grasland als het areaal boven deze $20 \%$ ligt. 


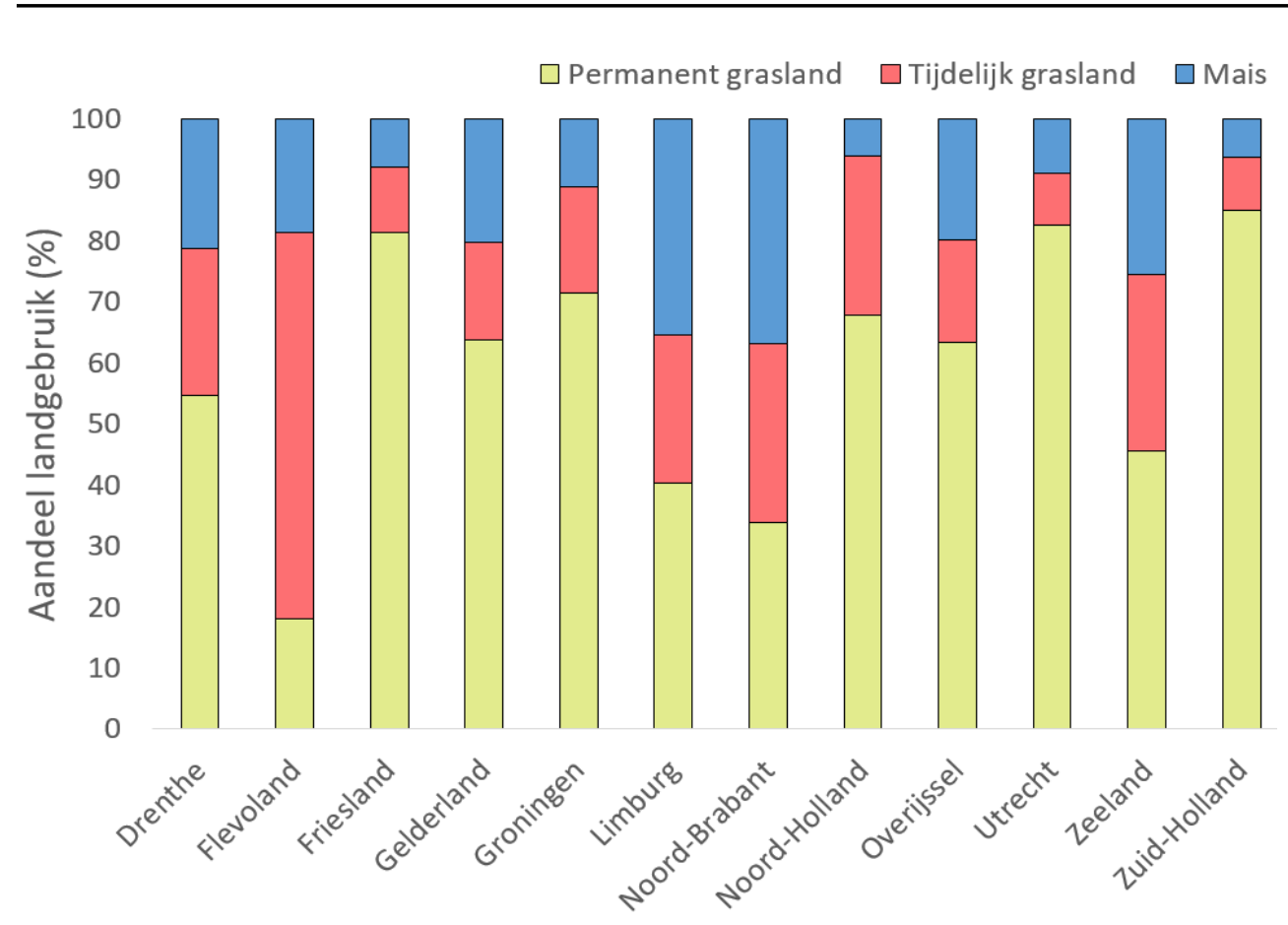

Figuur 9 Het gemiddelde aandeel blijvend grasland, tijdelijk grasland en maisteelt (in \%) per provincie, gebaseerd op gegevens uit de Basisregistratie Percelen van 2017.

De tweede maatregel voor meer blijvend grasland is gebaseerd op het plan voor grondgebonden melkveehouderij van de Commissie Grondgebondenheid uit 2018. ${ }^{4}$ Hierbij moet elk melkveehouderijbedrijf in 2025 minimaal 65\% van de eiwitbehoefte op eigen grond telen of via buurtcontracten bemachtigen, waardoor de import van eiwitrijk krachtvoer wordt beperkt. Aangezien per hectare gras veel meer eiwit beschikbaar is dan uit snijmais, is de verwachting dat dit leidt tot meer grasland en minder snijmais. Op basis van het advies zou dat leiden tot een afname van het snijmaisareaal met ruim $40 \%$. Voor de modellering van deze maatregel is aangenomen dat per postcodegebied $40 \%$ van het areaal snijmais wordt omgezet naar blijvend grasland. Tegelijkertijd kan dan ook 40\% van het areaal tijdelijk grasland areaal worden omgezet naar blijvend grasland, aangezien dat niet meer nodig is in een rotatie met snijmais.

\subsubsection{Aanvoer externe organische stof}

\subsubsection{Extra vaste mest}

Voor toepassing van deze maatregel is aangenomen dat door gebruik van nieuwe stalsystemen en mestverwerking een deel van de geëxporteerde koolstof in mest toch binnen Nederland kan worden toegepast. Deze vaste mest komt met name beschikbaar na mestscheiding en verdere verwerking en in vaste fractie na scheiding bij de bron. De huidige export en verwerking van kippenmest blijft doorgaan, maar de export van (verwerkte) runder- en varkensmest wordt verlaagd en de koolstof uit deze mest wordt dan binnen Nederland toegediend. Bij gebrek aan data is de aanname gemaakt dat deze maatregel op $25 \%$ van de huidige export van runder- en varkensmest kan worden toegepast. Op basis van mestexportdata van NCM (2020) is de huidige mestexport op basis van fosfaat bepaald. Als dit via de koolstof-fosfaatverhouding van de mest wordt omgerekend naar koolstof, komt dit neer op 115.000 kton extra $\mathrm{C}$ die in dierlijke mest naar de bodem kan worden aangevoerd. Dit is een verhoging van $6 \%$ van de huidige C-aanvoer uit dierlijke mest. Deze hoeveelheid is naar rato van de stikstofgift uit dierlijke mest over Nederland en de verschillende gewassen verdeeld. In de praktijk zal deze vaste mest waarschijnlijk meer voor specifieke teelten of op percelen met een laag organischestofgehalte worden toegepast. Hierdoor is de ruimtelijke verdeling van de vastlegging in werkelijkheid anders dan in de modelsimulatie, maar dat zal voor de totale potentie niet veel uitmaken.

\footnotetext{
${ }^{4}$ https://edepot.wur.nl/446638
} 


\subsubsection{Extra compost}

In Nederland wordt ongeveer 1800 kton compost per jaar geproduceerd, waarvan 500 kton gftcompost en 1300 kton groencompost. Van de gft-compost gaat ongeveer $75 \%$ naar de landbouw en van de groencompost ongeveer 50\% (BVOR, 2017). Voor het doorrekenen van deze maatregel is aangenomen dat het aandeel compost dat naar de landbouw gaat, wordt verhoogd naar $87,5 \%$ voor gft-compost en $75 \%$ voor groencompost. Dit was omgerekend 387 kton extra compost, waarvan 62 kton gft-compost en 325 kton groencompost. Dit is een subjectieve aanname, aangezien er geen studie beschikbaar is met een kwantitatieve inschatting van de potentieel toekomstige compostproductie in Nederland. Voor het uiteindelijke mitigatie-effect van deze maatregel is het wel van belang dat het totale volume compost toeneemt, en niet dat het een verschuiving van de composttoepassing betekent, bijvoorbeeld van parken naar landbouw.

In het model gaan we ervan uit dat compost wordt toegepast op land dat gebruikt wordt voor akkerbouw en snijmais. In het model wordt rekening gehouden met de geldende bemestingsnormen, dit betekent dat extra compost resulteert in een kleine afname van de toediening van (varkens)drijfmest vanwege beperkingen in de fosfaatgebruiksnorm. Compost wordt in RothC, net als andere organischestof-aanvoeren, opgedeeld in de verschillende koolstofpools. Compost wordt verdeeld over de pools in een verhouding: 15\% DPM, 70\% RPM en 15\% HUM (Peltre et al., 2012).

\subsubsection{Vanggewassen/groenbemesters}

In Nederland wordt op ruim een derde van het areaal bouwland al een groenbemester geteeld (Tabel 2). Een groot deel hiervan is gerelateerd aan de wettelijke verplichting om een vanggewas na mais op zand toe te passen. Het gaat dan om een late oogst en met name grasachtige vanggewassen (Engels raaigras, Italiaans raaigras en tijdelijk grasland). Er is echter nog potentie voor extra toepassing en verhoging van de opbrengst van de groenbemesters. $\mathrm{De} \mathrm{CO}_{2}$ die vastgelegd kan worden door groenbemesters hangt af van de soort groenbemester en de zaaitijd (Tabel 3). Hier geldt dat vroeger zaaien vaak (meer dan) twee keer zoveel biomassa oplevert en dus ook twee keer zoveel Caanvoer naar de bodem kan opleveren.

Tabel 3 Verschillende groenbemesters, effectieve organische stof die ze toevoegen aan de bodem (afhankelijk van de zaaitijd) en C-aanvoer naar de bodem (gebaseerd op 45\% C-gehalte in de OS van de groenbemesters), gebaseerd op Selin Norén et al. (2021).

\begin{tabular}{|c|c|c|c|c|c|}
\hline \multirow[b]{2}{*}{ Groenbemester } & \multirow[t]{2}{*}{ Zaaitijd } & \multicolumn{3}{|c|}{ EOS (kg/ha) } & \multirow[t]{2}{*}{ C aanvoer ( $\mathrm{kg} / \mathrm{ha})$} \\
\hline & & Blad & Wortel & Totaal & \\
\hline \multirow[t]{3}{*}{ Bladrammenas } & Juli & 2100 & 550 & 2650 & 4232 \\
\hline & Augustus & 900 & 500 & 1400 & 2254 \\
\hline & September & 500 & 250 & 750 & 1206 \\
\hline \multirow[t]{3}{*}{ Gele mosterd } & Juli & 1300 & 800 & 2100 & 2418 \\
\hline & Augustus & 850 & 300 & 1150 & 1336 \\
\hline & September & 500 & 150 & 650 & 757 \\
\hline \multirow[t]{2}{*}{ Voederwikke } & Augustus & 500 & 400 & 900 & 1293 \\
\hline & September & 250 & 100 & 350 & 553 \\
\hline \multirow[t]{2}{*}{ Tagetes (afrikaantjes) } & Juli & 1450 & 1000 & 2450 & 3321 \\
\hline & Augustus & 700 & 700 & 1400 & 1875 \\
\hline \multirow[t]{3}{*}{ Japanse Haver } & Juli & 1550 & - & - & 3036 \\
\hline & Augustus & 850 & 550 & 1400 & 1681 \\
\hline & September & 400 & 250 & 650 & 781 \\
\hline Italiaans raaigras & Augustus & 700 & 1000 & 1700 & 3418 \\
\hline \multirow[t]{3}{*}{ Mengsel ( 3 soorten) } & Juli & 2100 & 1000 & 2650 & 4144 \\
\hline & Augustus & 900 & 1000 & 1700 & 2532 \\
\hline & September & 500 & 250 & 750 & 1003 \\
\hline \multirow[t]{3}{*}{ Mengsel (12 soorten) } & Juli & 2100 & 1000 & 2650 & 4239 \\
\hline & Augustus & 900 & 1000 & 1700 & 2551 \\
\hline & September & 500 & 250 & 750 & 1025 \\
\hline
\end{tabular}


Voor de maatregel is gekeken na welke gewassen potentieel een vanggewas/groenbemester kan worden toegepast en of dit een vroege of late zaaitijd zal zijn. Ook is per gewas rekening gehouden met de slagingskans van de groenbemester. Bij suikerbieten bijvoorbeeld wordt een deel zo laat in het seizoen geoogst dat een succesvolle groenbemester niet meer mogelijk is. Gebaseerd op een update van de kengetallen Effectieve Organische Stof die in Slim Landgebruik en PPS Beter Bodem Beheer zijn bepaald (Selin Norén et al., 2021) en de humificatiecoëfficiënt, is de gemiddelde C-input per groenbemester afgeleid (Tabel 3). Aangezien er geen informatie bekend is over welk vanggewas na welke teelt wordt gebruikt, is uitgegaan van een gewogen gemiddelde van de huidige groenbemesters/vanggewassen. Dit resulteert in een gemiddelde C-aanvoer van $2900 \mathrm{~kg} \mathrm{C} / \mathrm{ha}$ voor een vroege groenbemester en $1100 \mathrm{~kg} \mathrm{C} /$ ha voor een late groenbemester.

\subsubsection{Stro achterlaten}

Bij graangewassen wordt vaak een groot deel van de gewasresten als stro van het veld afgevoerd. Op basis van informatie uit het Bedrijven Informatienet (BIN) is voor tarwe en gerst (belangrijkste graangewassen) bekend hoeveel er nu wordt afgevoerd (respectievelijk 62 en 43\%). Voor andere strogewassen was deze informatie niet beschikbaar en is de volgende aanname gemaakt: $25 \%$ afvoer voor stro van korrelmais en $50 \%$ voor de overige strogewassen (haver, rogge, koolzaad, triticale en overige granen). Voor het doorrekenen van de maatregel wordt het percentage afvoer op $0 \%$ gezet en zal dus $100 \%$ van de gewasresten van graangewassen op het land achterblijven. Doordat een deel van de stro anders als vaste mest ook weer terug naar de bodem zou komen, wordt de potentiële koolstofvastlegging van deze maatregel mogelijk wel deels overschat.

\subsubsection{Snijmais met strokenfrees}

Bij deze maatregel wordt ervan uitgegaan dat snijmais in rotatie met tijdelijk grasland geteeld wordt in een rotatie van 3 jaar snijmais en 3 jaar gras. In plaats van gras te ploegen voor het inzaaien van de mais, wordt gebruikgemaakt van een strokenfrees, waardoor een deel van het gras blijft staan. De $\mathrm{C}$-aanvoer die deze maatregel kan leveren, wordt geschat op 2,1 ton $\mathrm{C} / \mathrm{ha}$. Dit is gebaseerd op de helft van $\mathrm{C}$-aanvoer van tijdelijk grasland $(0,5 * 3,4$ ton $\mathrm{C} / \mathrm{ha})$, de volledige $\mathrm{C}$-aanvoer van snijmais $(1,1$ ton $\mathrm{C} / \mathrm{ha}$ ) en een correctie voor $\mathrm{C}$-aanvoer uit huidige groenbemesters (geschat op ongeveer de helft van de gemiddelde opbrengst van groenbemesters; 0,7 ton $\mathrm{C} / \mathrm{ha}$ ) om dubbeltelling te voorkomen. $\mathrm{Er}$ is aangenomen dat deze maatregel toepasbaar is op het gehele snijmaisareaal, wat voor Nederland overeenkomt met 205.000 ha.

\subsubsection{Verhogen gewasproductie}

Door beter gewasbeheer met irrigatie, rasverbetering en/of betere bemesting en nutriëntenbenutting als voorbeelden kan de gewasopbrengst toenemen en daardoor ook de hoeveelheid gewasresten. Op basis van historische trends in gewasopbrengst voor de belangrijkste gewassen is een inschatting gemaakt met welk percentage de gewasopbrengst nog verder kan stijgen en daarmee de aanvoer van $\mathrm{C}$ naar de bodem kan toenemen. Om een idee van de yield gap te krijgen, hebben we voor de huidige akkerbouwgewassen de opbrengst over de laatste 25 jaar bekeken (CBS). Door middel van een lineaire regressie hebben we bepaald of er nog een positieve trend aanwezig is in de opbrengst over de laatste jaren. In de situatie dat deze trend aanwezig was, hebben we het lineaire model doorgetrokken tot 2030 (Tabel 4). Vervolgens hebben we de prognose van de gewasproductie vergeleken met oogsten behaald in afzonderlijke gebieden van Nederland om een inschatting te maken of het gebruikte oogstniveau nog realistisch is of aanpassing behoeft.

Uit deze analyse volgt dat er vooral winst te halen is bij (zaai)uien, zetmeelaardappelen, mais en vooral suikerbieten (NB Geen van de voorspelde waarden hebben we onrealistisch bevonden - deze zijn zeker al behaald in verschillende regio's in Nederland). Bij het doorrekenen van deze maatregel zijn de gewasopbrengsten verhoogd met deze factor van de relatieve yield gap, waarbij het model verder het effect op de hoeveelheid gewasresten en effect op bodemkoolstof berekent. 
Tabel 4 Yield gap van akkerbouwgewassen in Nederland gebaseerd op gewasopbrengst-data van het CBS en regressieanalyse van de historische trend (in ton/ha). De maximale waarde geeft het maximum aan dat uit de regressieanalyse komt. In enkele gevallen is deze waarde in 1995 behaald en is in de jaren erna de opbrengst verminderd.

\begin{tabular}{lrrrrr} 
& Opbrengst uit CBS & Voorspelling & Data uit regressieanalyse \\
\cline { 2 - 4 } & 1995 & 2019 & 2030 & Max & Yield gap $($ max-2019) \\
Zaai-uien & 53,9 & 50,3 & 56,2 & 56,2 & 5,9 \\
\hline Consumptieaardappelen & 48,9 & 47,9 & 48,7 & 48,9 & 1,0 \\
\hline Pootaardappelen & 34,7 & 35,8 & 36,3 & 36,3 & 0,5 \\
\hline Zetmeelaardappelen & 42,8 & 37,8 & 40,1 & 42,8 & 5,0 \\
\hline Wintergerst & 5,8 & 9,1 & 9,9 & 9,9 & 0,8 \\
\hline Zomergerst & 5,8 & 6,6 & 7,0 & 7,0 & 0,4 \\
\hline Haver & 5,4 & 6 & 5,3 & 6 & NA \\
\hline Corn cob mix & 13,8 & 10,3 & 9,4 & 13,8 & 3,5 \\
\hline Korrelmais & 12,5 & 10,3 & 11,2 & 12,5 & 2,2 \\
\hline Rogge & 5,3 & 3,6 & 2,5 & 5,3 & 1,7 \\
\hline Wintertarwe & 8,4 & 9,8 & 9,6 & 9,8 & $\mathrm{NA}$ \\
\hline Zomertarwe & 6,7 & 7,1 & 7,0 & 7,1 & $\mathrm{NA}$ \\
\hline Triticale & 5,5 & 5,4 & 5,4 & 5,5 & 0,1 \\
\hline Cichorei & 39,1 & 43,2 & 44,3 & 44,3 & 1,1 \\
\hline Koolzaad & 3,4 & 3,4 & 3,8 & 3,8 & 0,4 \\
\hline Vezelvlas & 6,5 & 5,8 & 4,2 & 6,5 & 0,7 \\
\hline Bruine bonen & 2,6 & 2,5 & 2,3 & 2,6 & 19,7 \\
\hline Suikerbieten & 52,5 & 83,9 & 103,6 & 103,6 & 6,0 \\
\hline Snijmais & 37,9 & 43 & 49,0 & 49,0 & 0,1 \\
\hline
\end{tabular}

\subsubsection{Akkerranden}

Volgens Elbersen et al. (2018) worden momenteel op 3\% van het landbouwareaal akkerranden toegepast: dit is dan netto een areaal van ongeveer 800 ha in Nederland. Door de regels die gelden voor het meetellen van akkerranden als onderdeel van de vergroening (zie paragraaf 2.8) wordt de plaatsingsruimte voor organische mestproducten kleiner. Voor het doorrekenen van deze maatregel is aangenomen dat akkerranden op het volledige akkerbouw- en snijmaisareaal worden toegepast en dat $2 \%$ van dat areaal wordt ingericht als akkerranden. Informatie over de drogestofopbrengst van de akkerranden is maar zeer beperkt beschikbaar. Op basis van vergelijkbare gewassen (kruidachtigen, granen, gras) is een koolstofaanvoer uit plantenresten van 4 ton C/ha/jaar akkerrand aangenomen. Op dit areaal akkerrand wordt geen bemesting meer toegepast.

\subsubsection{Vogelakkers}

Vogelakkers worden vaak ingericht met een meerjarig groenvoedergewas (vaak rode klaver op zandgrond en luzerne op kleigrond), afgewisseld met natuurbraakstroken. Voor de modellering van vogelakkers zijn we uitgegaan van percelen met luzerne, aangezien rode klaver geen apart gewas in MITERRA-NL was. De koolstofaanvoer voor vogelakkers is gezet op de C-aanvoer voor gewasresten van luzerne (1,8 ton $\mathrm{C} / \mathrm{ha} / \mathrm{jaar}$ ) plus een extra C-aanvoer vanuit de stroken met natuurbraak, die niet geoogst wordt, waardoor er meer biomassa voor de bodem overblijft. Hiervoor is aangenomen dat die natuurbraak $30 \%$ van het perceel beslaat en tot een extra C-aanvoer leidt van 1 ton $\mathrm{C} / \mathrm{ha} / \mathrm{jaar}$. In het model is voor deze maatregel aangenomen dat $2 \%$ van het areaal intensieve akkerbouwgewassen (aardappelen, suikerbieten, bloembollen en uien) vervangen wordt door vogelakkers. 


\subsection{Resultaten}

\subsubsection{Effect van maatregelen op bodemkoolstofbalans}

Voor de baseline is de huidige jaarlijkse C-aanvoer in grasland gemiddeld $6400 \mathrm{~kg} \mathrm{C} / \mathrm{ha}$, terwijl dit in akkerland 44\% lager ligt met $3600 \mathrm{~kg} \mathrm{C} /$ ha (Figuur 10). Het merendeel van de C-aanvoer komt uit gewasresten (74 en 58\% respectievelijk voor grasland en akkerland), terwijl C uit dierlijke mest en compost een kleiner aandeel heeft. De afbreekbaarheid van de gewasresten is echter wel hoger vergeleken met - al bewerkte en afgebroken - dierlijke mest en compost. De aanvoer van koolstof naar de bodem kan verhoogd worden door de eerder in hoofdstuk 2 beschreven maatregelen toe te passen. De maatregelen zoals beschreven in paragraaf 3.3 zijn individueel doorgerekend, maar ook de combinatie/stapeling van de maatregelen is doorgerekend. Hierbij zijn alleen de 60-20-20landgebruikmaatregel en akkerranden niet meegenomen, om dubbeltelling te voorkomen. In de berekening wordt rekening gehouden met interactie tussen maatregelen; dit kan positief zijn, zoals bij het verhogen van het aandeel rustgewassen en stro achterlaten, of negatief, zoals meer blijvend grasland en snijmais met strokenfrees. Figuur 10 laat de aanvoer van koolstof naar de bodem zien voor de baseline en de combinatie van maatregelen. Voor grasland is de toename van de C-aanvoer met 3,3\% beperkt, omdat meer maatregelen maar een beperkt effect heeft op een hectare bestaand grasland en de potentie met name ligt in meer blijvend grasland. Een hectare akkerland heeft meer potentie, waar geschat wordt dat de C-aanvoer met 36\% verhoogd kan worden. De C-aanvoer kan met name verhoogd worden door de aanvoer van meer gewasresten en groenbemesters.

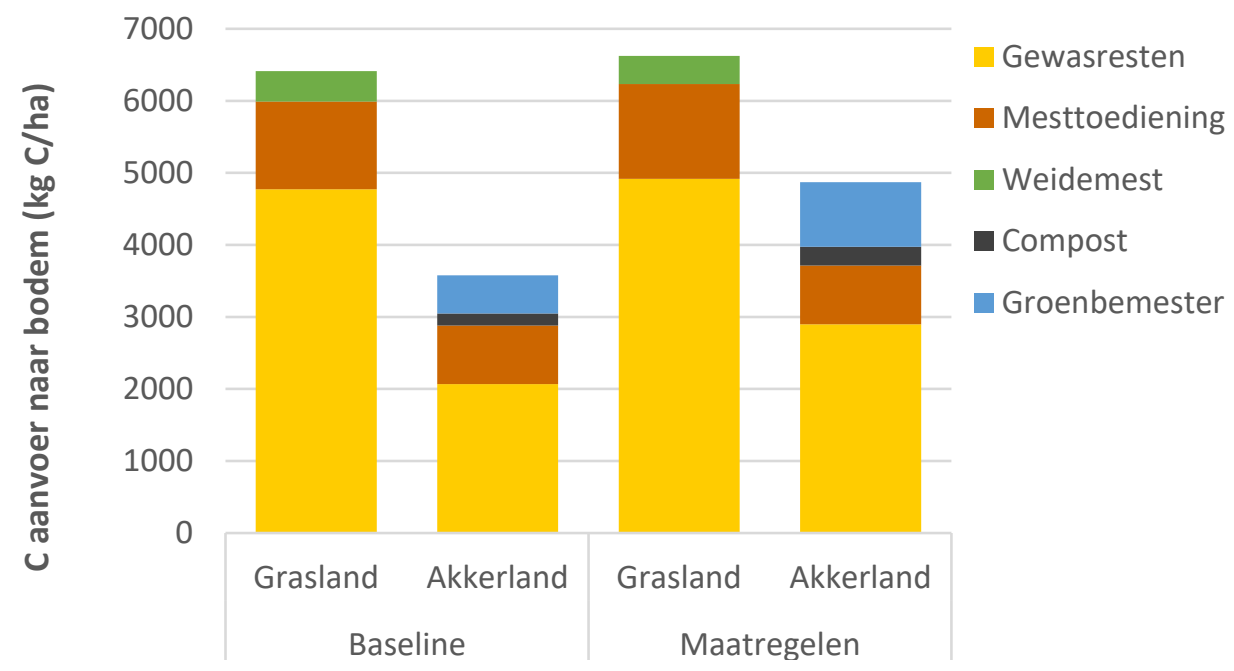

Figuur 10 Gemiddelde C-aanvoer voor grasland en akkerland voor baseline en het scenario met combinatie van maatregelen.

Grasland heeft zowel op zandgrond als op kleigrond gemiddeld een positieve koolstofbalans $(0,01$ en 0,12 ton $\mathrm{C} / \mathrm{ha} / \mathrm{jaar}$ respectievelijk), terwijl akkerland een negatieve balans toont met $-0,7$ ton $\mathrm{C} / \mathrm{ha} / \mathrm{jaar}$ voor akkerland op zandgrond en $-0,17$ ton $\mathrm{C} / \mathrm{ha} / \mathrm{jaar}$ voor akkerland op kleigrond. Maatregelen kunnen ertoe leiden dat de C-balans van grasland positief wordt met op zandgrond 0,06 ton $\mathrm{C} / \mathrm{ha} / \mathrm{jaar}$ en op kleigrond 0,17 ton $\mathrm{C} / \mathrm{ha} / \mathrm{jaar}$. In de akkerbouw kan er op zandgrond een minder negatieve balans behaald worden $(-0,5$ ton $\mathrm{C} / \mathrm{ha} / \mathrm{jaar})$ en op kleigrond zelfs een licht positieve balans $(0,1$ ton $\mathrm{C} / \mathrm{ha} / \mathrm{jaar})$. Het ruimtelijke effect van maatregelen op de koolstofbalans laat zien dat veel gebieden die in de baseline een licht negatieve C-balans tonen (Figuur 6), de potentie hebben om een licht positieve balans te tonen als meerdere maatregelen gecombineerd worden toegepast. In Zeeland, Noord-Brabant en delen van Oost-Nederland blijft de balans echter negatief. 


\subsubsection{Technische potentie C-vastlegging}

De berekende technische potentie van maatregelen voor $\mathrm{CO}_{2}$-vastlegging in de bodem is weergegeven in Figuur 11 en Tabel 5. Hierbij is onderscheid gemaakt naar zand- en kleigronden. De totale potentie voor de individuele maatregelen is voor zand en klei min of meer gelijk en elk ruim 500 kton $\mathrm{CO}_{2}$ per jaar. Toch is er wel een duidelijk verschil in bijdrage van de verschillende maatregelen. Op zandgronden hebben de maatregelen voor de melkveehouderij een groter aandeel, terwijl op kleigrond de akkerbouw-gerelateerde maatregelen een groter aandeel hebben. De maatregelen met de hoogste potentie zijn 1) meer blijvend grasland (door uitvoeren grondgebondenheid of toepassen van 60-2020 landgebruik), 2) toepassen van vanggewassen/groenbemesters en 3) verhogen aandeel rustgewassen ten koste van aandeel intensieve gewassen. Ook de maatregelen extra vaste mest, achterlaten van stro, snijmais met strokenfrees en extra compost hebben nog een behoorlijke potentie. Voor vogelakkers en verbeterde gewasopbrengst is de potentie minimaal en voor akkerranden is deze zelfs negatief. De potentie voor de combinatie van maatregelen, exclusief de maatregel 60-20-20 landgebruik om dubbeltelling met de maatregel meer blijvend grasland te voorkomen, is ongeveer 0,9 Mton $\mathrm{CO}_{2}$ per jaar (zie Tabel 5 ). Hierbij is rekening gehouden met de mogelijke interacties tussen de maatregelen.

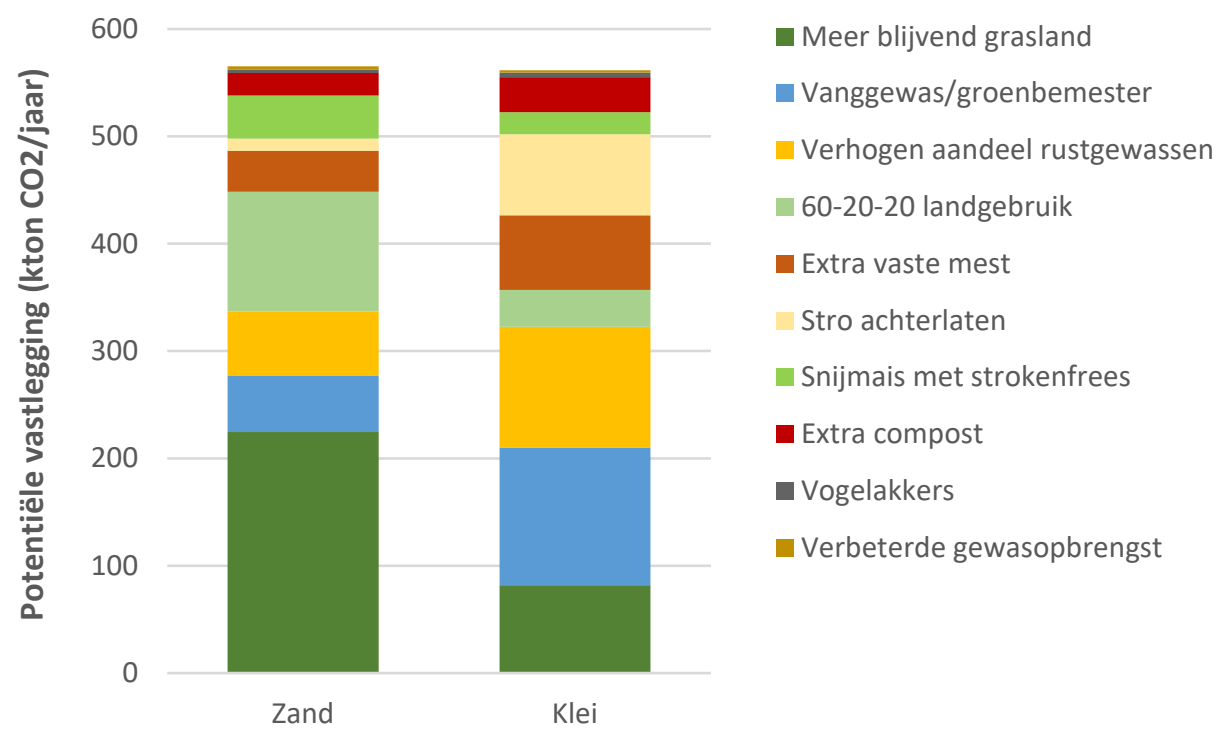

Figuur 11 Totale potentiële $\mathrm{CO}_{2}$-vastlegging voor maatregelen uitgesplitst naar zand-en kleigrond.

Tabel 5 Potentiële $\mathrm{CO}_{2}$-vastlegging (totaal en per ha) en additioneel areaal waarop de maatregel kan worden toegepast, uitgesplitst naar zand- en kleigrond.

\begin{tabular}{|c|c|c|c|c|c|c|}
\hline \multirow[t]{2}{*}{ Maatregelen } & \multicolumn{2}{|c|}{$\begin{array}{l}\text { Vastlegging totaal } \\
\text { (kton } \mathrm{CO}_{2} / \text { jaar) }\end{array}$} & \multicolumn{2}{|c|}{$\begin{array}{c}\text { Potentieel additioneel } \\
\text { areaal (1000 ha) } \\
\end{array}$} & \multicolumn{2}{|c|}{$\begin{array}{l}\text { Vastlegging per ha } \\
\text { (ton } \mathrm{CO}_{2} / \text { ha/jaar) }\end{array}$} \\
\hline & Zand & Klei & Zand & Klei & Zand & Klei \\
\hline Meer blijvend grasland & 224 & 82 & 88 & 51 & 2,55 & 1,59 \\
\hline Vanggewas/groenbemester & 52 & 128 & 63 & 89 & 0,83 & 1,44 \\
\hline Verhogen aandeel rustgewassen & 60 & 113 & 32 & 35 & 1,86 & 3,25 \\
\hline 60-20-20 landgebruik & 112 & 34 & 53 & 24 & 2,09 & 1,45 \\
\hline Extra vaste mest & 38 & 70 & 662 & 763 & 0,06 & 0,09 \\
\hline Stro achterlaten & 11 & 76 & 34 & 114 & 0,33 & 0,66 \\
\hline Snijmais met strokenfrees & 40 & 21 & 129 & 51 & 0,31 & 0,40 \\
\hline Extra compost & 21 & 32 & 293 & 387 & 0,07 & 0,08 \\
\hline Vogelakkers & 3 & 4 & 2 & 3 & 1,65 & 1,30 \\
\hline Verbeterde gewasopbrengst & 3 & 2 & 235 & 232 & 0,01 & 0,01 \\
\hline Akkerranden & -1 & -1 & 6 & 8 & $-0,17$ & $-0,07$ \\
\hline $\begin{array}{l}\text { Realistische combinatie van } \\
\text { maatregelen }\end{array}$ & 428 & 459 & 662 & 763 & 0,65 & 0,60 \\
\hline
\end{tabular}


Naast de totale $\mathrm{CO}_{2}$-vastleggingpotentie is het ook van belang om te weten hoeveel een maatregel gemiddeld per hectare kan vastleggen, zodat een agrarisch ondernemer een goede afweging kan maken welke maatregelen het effectiefst zijn voor zijn bedrijf en omstandigheden. Tabel 5 geeft een overzicht van de $\mathrm{CO}_{2}$-vastlegging per ha en voor welk additioneel areaal dit in Nederland toepasbaar is. Over het algemeen kan op een kleigrond meer $\mathrm{CO}_{2}$ worden vastgelegd, door de binding van organische stof met de kleideeltjes. Voor de akkerbouwmaatregelen (vanggewas/groenbemester, verhogen aandeel rustgewassen en stro achterlaten) is de $\mathrm{CO}_{2}$-vastlegging per ha hoger voor kleigronden, terwijl de twee grasland maatregelen (meer blijvend grasland en 60-20-20 landgebruik) juist een hogere $\mathrm{CO}_{2}$-vastlegging per ha hebben op zandgrond. Op grasland onder klei is het organischestofgehalte vaak al hoger, omdat hier minder vaak gebruik wordt gemaakt van rotaties met snijmais, terwijl snijmais op zandgrond vaak een sterk negatieve bodem-C-balans heeft (Lesschen et al., 2020). Voor extra vaste mest en compost is de potentie per ha erg laag, maar dat komt omdat deze hoeveelheid mest/compost naar rato over het gehele landbouwareaal is toegepast. In de praktijk zal dit op een kleiner areaal worden toegepast, waardoor de vastlegging per ha dan wel groter wordt, maar niet voor het gehele landbouwareaal. Voor deze twee maatregelen is vooral de beschikbaarheid van extra vaste mest en compost de beperkende factor.

\subsubsection{Huidige implementatiegraad}

Voor het toepassen van een maatregel is het ook van belang om te weten in hoeverre een maatregel nu al wordt toegepast ten opzichte van wat potentieel mogelijk is. Tabel 6 geeft een overzicht van de huidige implementatiegraad voor de maatregelen. Dit is grotendeels gebaseerd op de data uit BRP voor 2017. Voor veel maatregelen is de huidige implementatiegraad al behoorlijk hoog. Voor de blijvend grasland-maatregel komt dat doordat een groot deel van het potentiële areaal nu al blijvend grasland is. Ook voor de maatregelen van extra organischestof-aanvoer uit bemesting is de potentie beperkt, aangezien nu al veel dierlijke mest en compost worden toegepast en er maar een beperkte hoeveelheid extra beschikbaar is (compost) of toegepast mag worden (dierlijke mest).

Tabel 6 Inschatting van de huidige implementatiegraad voor de maatregelen, waarbij de gemodelleerde potentiële $\mathrm{CO}_{2}$-vastlegging op $100 \%$ gezet is.

\begin{tabular}{lcl} 
Maatregelen & $\begin{array}{c}\text { Huidige implementatie- } \\
\text { graad }(\%)\end{array}$ & Omschrijving \\
Meer blijvend grasland & 79 & Huidig areaal blijvend grasland versus potentieel \\
\hline Vanggewas/groenbemester & 64 & Huidig areaal rustgewassen versus potentieel \\
\hline Verhogen aandeel rustgewassen & 69 & Huidig areaal blijvend grasland versus potentieel \\
\hline $60-20-20$ landgebruik & 87 & Huidige C-input uit mest versus potentieel \\
\hline Extra vaste mest & 94 & Gemiddeld aandeel stro afgevoerd \\
\hline Stro achterlaten & 56 & Geen data, inschatting \\
\hline Snijmais met strokenfrees & 1 & Huidig compost gebruik versus potentieel \\
\hline Extra compost & 72 & Inschatting huidig areaal vogelakkers (300 ha) \\
\hline Vogelakkers & 6 & Huidig C-input gewasresten akkerbouw versus potentieel \\
\hline Verbeterde gewasopbrengst & 99 & Huidig netto areaal akkerranden (800 ha)
\end{tabular}

Voor vanggewas/groenbemester is het additionele areaal waarop deze maatregel kan worden toegepast ook beperkt (ongeveer $150.000 \mathrm{ha}$ ). Echter, naast uitbreiding van het areaal is er ook potentie voor het toenemen van de C-aanvoer uit de vanggewassen/groenbemesters. Dit kan door deze gewassen eerder in te zaaien en daarmee meer biomassa te produceren en achter te laten. Bij verbeterde opbrengsten van de hoofdgewassen is er nauwelijks extra potentieel. Voor een deel van deze gewassen is er wel potentie voor opbrengststijging (zie paragraaf 3.3.8), maar voor veel van deze gewassen, zoals suikerbieten, is er niet direct een relatie tussen gewasopbrengst en gewasresten. Vogelakkers en akkerranden zijn maatregelen die nu nog heel weinig worden toegepast. Toch is de totale potentie van deze maatregelen erg beperkt. Snijmais met strokenfrees wordt nu nog maar zeer beperkt toegepast, hoewel deze maatregel in principe op het gehele snijmaisareaal toepasbaar is. Er is echter nog maar beperkt onderzoek naar gedaan en mogelijk zijn er nog wel 
belemmeringen in de praktijk, zoals opbrengstderving of droogtestress, waardoor de realistische potentie voor deze maatregel nog onzeker is.

\subsubsection{Ruimtelijke verdeling van de potentie}

De potentiële $\mathrm{CO}_{2}$-vastlegging per maatregel is ook ruimtelijk weergegeven om te laten zien welke maatregel in welke regio het meeste perspectief biedt (Figuur 12). Meer blijvend grasland (306 kton $\mathrm{CO}_{2} /$ jaar) en 60-20-20 landgebruik (146 kton $\mathrm{CO}_{2} / \mathrm{jaar}$ ) hebben een hoge potentie voor $\mathrm{CO}_{2-}$ vastlegging, met name door het omzetten van akkerland naar grasland. Deze omzetting leidt tot een veel hogere $\mathrm{C}$-aanvoer. Deze maatregelen hebben de hoogste potentie in het oosten van Nederland, Noord-Brabant en Zuid-Limburg (Figuur 12B en H) en dus daar waar nu relatief meer tijdelijk grasland en snijmais is.

Vanggewassen kunnen zo'n 180 kton $\mathrm{CO}_{2}$ per jaar extra vastleggen en hebben daarmee de hoogste potentie voor de Nederlandse akkerbouwgronden. In de gebieden waar mais op zandgrond geteeld wordt, is het al wel verplicht om na de oogst een groenbemester te zaaien, maar met vroeger inzaaien kan de opbrengst van de groenbemester - en daarmee de C-aanvoer naar de bodem - nog wel worden verhoogd. De maatregel heeft de hoogste potentie in delen van Nederland waar het areaal landbouwgrond hoog is (zoals Flevoland, Noordoost-Groningen, Noord-Holland en Zeeland, Figuur 12F). Het verhogen van het aandeel rustgewassen in de gewasrotatie resulteert in een extra $\mathrm{CO}_{2}$-vastlegging van $173 \mathrm{kton}$ per jaar. Het effect van deze maatregel is sterk gebiedsafhankelijk (Figuur 12A) en heeft de hoogste potentie in het noorden van Noord-Holland, Flevoland en delen van Zeeland. In deze gebieden vindt veel intensieve akkerbouw plaats met o.a. suikerbieten, aardappelen, uien, en bollenteelt en het aandeel rustgewas in het bouwplan is hier nu relatief laag (vooral in NoordHolland en Flevoland).

Het toedienen van extra verwerkte mest draagt zowel op grasland als op akkerland bij aan extra $\mathrm{CO}_{2}-$ vastlegging met $108 \mathrm{kton} \mathrm{CO}_{2} / \mathrm{jaar}$. Hierbij moet wel de kanttekening gemaakt worden dat er bij mestverwerking ook $\mathrm{CO}_{2}$ vrijkomt door het gebruik van fossiele brandstoffen (Brienza et al., 2021), maar er zijn ook kansen voor emissiereductie in combinatie met mestvergisting. Door de manier waarop de maatregel in het model is geïmplementeerd, is er nauwelijks ruimtelijk variatie en is de gemiddelde vastlegging ongeveer $70 \mathrm{~kg} \mathrm{CO} /$ ha/jaar (Figuur 12E).

Door de aanvoer uit gewasresten te verhogen door het stro op het land achter te laten in plaats van af te voeren (en elders te gebruiken), kan een extra $\mathrm{CO}_{2}$-vastlegging van $87 \mathrm{kton} \mathrm{CO}_{2}$ potentieel gerealiseerd worden. Voor grote delen van Nederland is de potentie van deze maatregel gering, maar in delen waar veel graangewassen geteeld worden (Zeeland, Flevoland en Groningen) is de potentie hoog (Figuur 12G). Snijmais die middels een strokenfrees ingezaaid wordt, kan potentieel een extra $\mathrm{CO}_{2}$-vastlegging van $61 \mathrm{kton} \mathrm{CO}_{2}$ realiseren. Doordat de graszode langer intact blijft, komt er minder zuurstof in de bodem en wordt organische stof minder snel afgebroken. Vooral in de gebieden waar veel snijmais geteeld wordt, heeft deze maatregel potentie (met name Noord-Brabant, Figuur 12C). Het toedienen van extra compost kan potentieel voor $53 \mathrm{kton}$ extra $\mathrm{CO}_{2}$-vastlegging in akkerland zorgen. Het zijn wederom de intensieve akkerbouwgebieden (Zeeland, Flevoland en het noordoosten van Groningen) die de hoogste potentie tonen voor deze maatregel. Vogelakkers leveren een geringe bijdrage ( $7 \mathrm{kton} \mathrm{CO}_{2}$ ) en worden vaak met andere doeleinden aangelegd (bv. verhogen biodiversiteit). Ook het verhogen van gewasopbrengsten levert slechts weinig extra gewasresten op die voor $\mathrm{CO}_{2}$ vastlegging kunnen zorgen $\left(5 \mathrm{kton} \mathrm{CO}_{2}\right)$. De maatregel akkerranden had zelfs een negatief effect op de koolstofvoorraad, omdat de akkerranden niet bemest worden en soms ook gewassen met een hogere aanvoer van organische stof vervangen. De maatregel is daarom niet opgenomen in de resultaten. Als de maatregel alleen zou worden toegepast bij intensieve gewassen met een lage OSaanvoer, zoals aardappelen en uien, zou het wel een positief, maar beperkt effect hebben. 


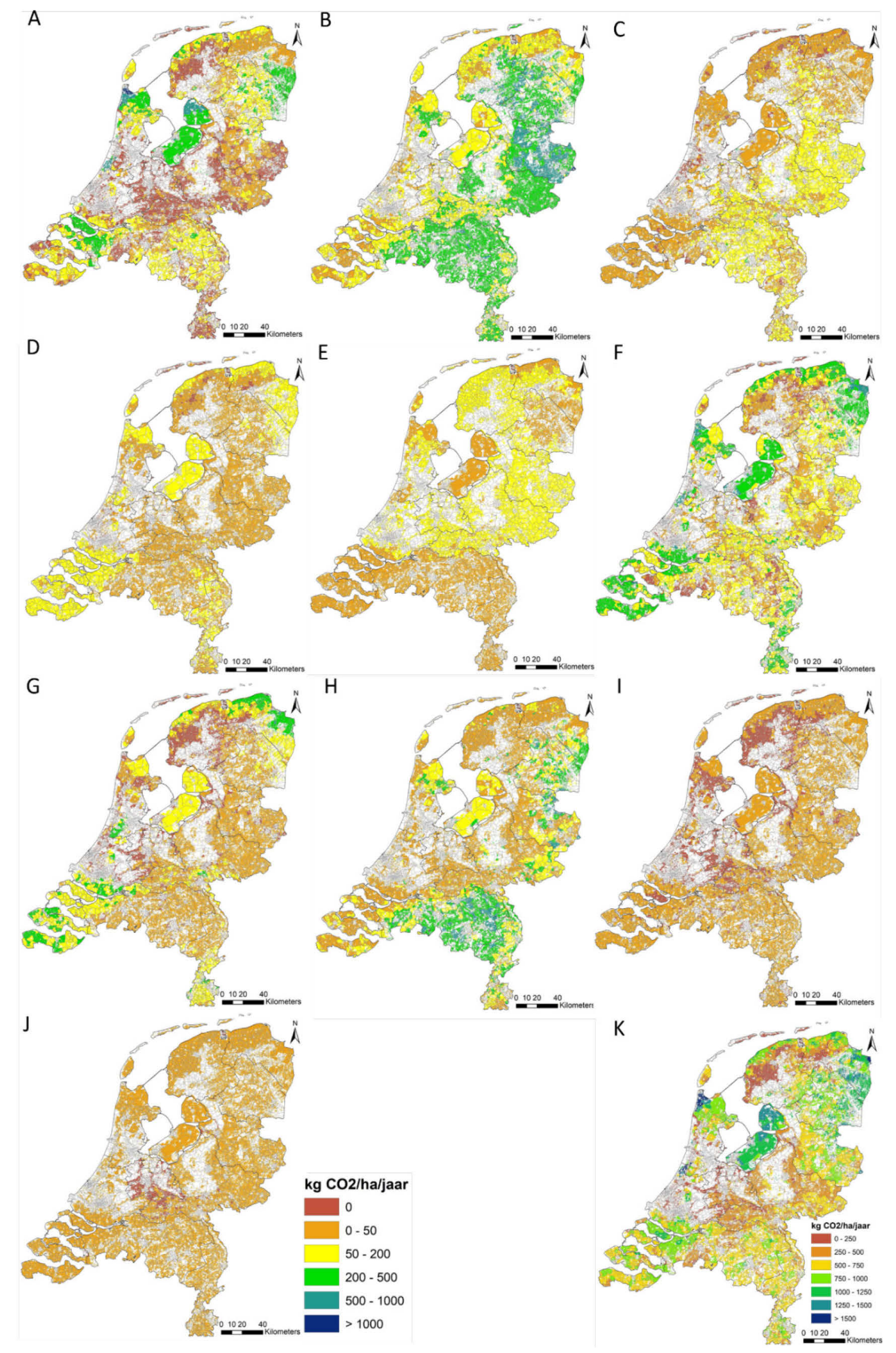

Figuur 12 Het effect van maatregelen die C-vastlegging bevorderen (in $\mathrm{kg} \mathrm{CO}_{2}$ per ha landbouwgrond per jaar) met A: verhogen aandeel rustgewassen, B: meer blijvend grasland, C: snijmais met strokenfrees, D: meer compost toedienen, E: meer vaste mest toedienen, F: vanggewas/ groenbemester, G: stro achterlaten, H: 60-20-20 landgebruik melkveehouderij, I: verhogen gewasproductie, J: vogelakkers. In alle kaartjes is dezelfde legenda gebruikt, waardoor de maatregelen direct met elkaar vergeleken kunnen worden. De potentiële $\mathrm{CO}_{2}$-vastlegging $\left(\mathrm{kg} \mathrm{CO}_{2} / \mathrm{ha}\right.$ landbouwgrond) in minerale landbouwbodems voor de combinatie van bovengenoemde maatregelen is weergegeven in $K$. 
De meeste maatregelen kunnen in combinatie met elkaar worden toegepast, alleen de maatregel optimaal landgebruik (60-20-20-regel) en meer blijvend grasland overlappen. De doorrekening van alle maatregelen samen (excl. de 60-20-20-landgebruikmaatregel) levert voor Nederlandse minerale landbouwgrond een technische potentiële $\mathrm{CO}_{2}$ - vastlegging op van 0,9 Mton $\mathrm{CO}_{2}$ per jaar. De potentie per ha landbouwgrond is het hoogst voor de gebieden met intensieve akkerbouw: Flevoland, het noorden van Noord-Holland en Noordoost-Groningen (Figuur 12K).

\subsection{Discussie en conclusie}

\section{Koolstofbalans}

In Nederland is de gemiddelde bodemkoolstofbalans op grasland positief, zowel op klei- als zandgronden. Maatregelen kunnen bijdragen aan het behoud van of aan het verhogen van deze koolstofbalans. Voor de Nederlandse akkerbouw (incl. snijmais) is de huidige berekende koolstofbalans gemiddeld echter negatief. Dit betekent dat er jaarlijks meer organische stof afgebroken wordt dan er aangevoerd wordt. Om $\mathrm{CO}_{2}$-emissies uit landbouwgrond te veranderen in netto $\mathrm{CO}_{2}$-vastlegging, is het noodzaak om deze balans positief te krijgen. De besproken maatregelen kunnen hieraan bijdragen, maar voor zandgronden met een hoger organischestofgehalte blijft het lastig om alleen met $\mathrm{CO}_{2}$ vastleggende maatregelen een positieve koolstofbalans te verkrijgen. Dit betekent echter wel dat ondanks het nemen van maatregelen - het OS-gehalte van de bodem nog altijd achteruitgaat, maar wel minder dan in de situatie zonder het nemen van maatregelen. In dat geval draagt het nemen van maatregelen zeker wel bij aan het verminderen van het effect op klimaatverandering: er komt immers minder $\mathrm{CO}_{2}$ in de atmosfeer terecht. Let wel: dit blijft een moeilijk punt voor monitoring, zeker als deze gebaseerd is op metingen van het OS-gehalte, omdat het dan lastig wordt om het positieve effect van de maatregel aan te tonen als er geen historische trend bekend is.

\section{Potentie voor $\mathrm{CO}_{2}$-vastlegging}

De totale technische potentie voor $\mathrm{CO}_{2}$-vastlegging in landbouwbodems wordt voor de combinatie van maatregelen geschat op 0,9 Mton $\mathrm{CO}_{2}$ per jaar ten opzichte van de huidige praktijk in 2017. Dit betekent dat de doelstelling uit het Klimaatakkoord van 0,4-0,6 Mton $\mathrm{CO}_{2}$ per jaar haalbaar is. Deze technische potentie is in lijn met de eerdere schatting uit Lesschen et al. (2012). Wel zijn er verschillen in welke maatregelen nu het meest bijdragen in vergelijking tot tien jaar geleden. De minder grondbewerking-maatregelen die in Lesschen et al. (2012) nog een grote bijdrage hadden aan de potentiële $\mathrm{CO}_{2}$-vastlegging, worden nu door voortschrijdend inzicht niet meer beschouwd als maatregelen die bijdragen aan netto C-vastlegging (zie paragraaf 2.10). De maatregelen die nu het meest bijdragen, zijn maatregelen die leiden tot een extra aanvoer van gewasresten (meer blijvend grasland, vanggewassen/groenbemesters en verhogen van aandeel rustgewassen). Dit zijn ook maatregelen die zorgen voor extra $\mathrm{C}$ in het systeem en geen/minder risico hebben op het verschuiven van koolstofstromen van locatie naar locatie. Deze verschuiving is een risico bij de maatregelen 'extra vaste mest' en 'extra compost'. In de grondgebonden veehouderij is de meeste $\mathrm{CO}_{2}$-vastlegging te bereiken met het omzetten van tijdelijk grasland en snijmais naar blijvend grasland. Voor akkerland is het zaaien van een groenbemester na de oogst een vrij eenvoudige maatregel die veel aan $\mathrm{CO}_{2}-$ vastlegging kan bijdragen. Aandacht moet daarbij uitgaan naar de zaaidatum en het type groenbemester. Het verhogen van het aandeel rustgewassen is in de intensieve akkerbouwregio's ook een belangrijke maatregel voor het verhogen van de $\mathrm{CO}_{2}$-vastlegging. Dit is echter wel een maatregel die vaak ten koste zal gaan van het economisch saldo en rendement.

Deze economische aspecten zijn uiteindelijk bepalend voor de toepassing van de maatregelen en daarmee de werkelijk te bereiken $\mathrm{CO}_{2}$-vastlegging. Voor de meeste maatregelen geldt dat deze leiden tot extra kosten, en dus niet zonder meer toegepast gaan worden als daar niet een vergoeding vanuit subsidies, hogere prijzen of carbon credits tegenover staat.

\section{Duur van vastlegging}

In de berekeningen voor de potentiële $\mathrm{CO}_{2}$-vastlegging is uitgegaan van de bodem-C-balans voor één jaar. Een toename in het organischestofgehalte van de bodem kan doorgaan tot de bodem weer een nieuw evenwicht bereikt tussen aanvoer en afbraak. We hebben in deze studie geen berekening uitgevoerd voor de langere termijn om te kijken wanneer dit evenwicht wel bereikt wordt. Op basis 
van simulaties met RothC zal dat wel langer dan vijftig jaar duren. Desondanks wordt de omvang van de $\mathrm{CO}_{2}$-vastlegging in de loop der tijd kleiner. In de Emissieregistratie in Nederland wordt voor veranderingen van de bodem-C-voorraad een standaardperiode van twintig jaar gebruikt, zoals aangegeven is in de IPCC-richtlijnen (IPCC, 2006). Onder Nederlandse klimaatomstandigheden zal deze periode langer zijn, omdat de processen van koolstofopbouw en afbraak langzamer verlopen vergeleken met warmere klimaten. Schulp en Verburg (2009) lieten zien dat verschillen in historisch landgebruik na meer dan honderd jaar nog steeds een deel van de variatie in OS-gehalte konden verklaren en er dus nog altijd geen nieuw evenwicht was bereikt. Resultaten van praktijkmetingen van het OS-gehalte onder grasland (De Wit et al., 2018; Iepema et al., 2021) laten zien dat na dertig tot veertig jaar een maximaal OS-gehalte wordt bereikt. Deze metingen zijn echter alleen gebaseerd op bodemmonsters van de bovenste $10 \mathrm{~cm}$; waarschijnlijk gaat de opbouw van de koolstofvoorraad nog wel langer door en dan met name in diepere lagen. De potentie voor additionele koolstofvastlegging in de bodem zoals voorgesteld in het Klimaatakkoord is dus een tijdelijk potentie. Desondanks kan koolstofvastlegging de eerstkomende decennia zeker bijdragen aan het realiseren van doelen voor klimaatneutraliteit en kwalificeert - mits goed uitgevoerd - als zogenaamde 'negative carbon technology'. Koolstofvastlegging in bodems moet dan naast de voordelen voor bodemkwaliteit ook met name gezien worden als een oplossing om tijd te kopen, zodat ondertussen andere emissiereducerende technieken verder ontwikkeld kunnen worden, om dan uiteindelijk te worden geïmplementeerd ter vervanging van een koolstofvastlegging in de bodem onder landbouwsystemen.

\section{Onzekerheden}

De geschatte extra koolstofvastlegging die bereikt kan worden met maatregelen die $\mathrm{CO}_{2}$-vastlegging bevorderen, is gebaseerd op 1 ) bestaande gegevens, 2) aannames en 3) modelberekeningen. In elk van deze drie factoren kunnen onzekerheden voorkomen die de uitkomsten beïnvloeden. Deze onzekerheden zijn zo klein mogelijk gemaakt door aan te sluiten bij de actueelste data van oude en lopende experimenten en waarnemingen, kennis en literatuurgegevens en door een procesmodel te kiezen dat uitgebreid gekalibreerd en gevalideerd is. Het RothC-model heeft verschillende invoergegevens nodig die niet allemaal op de benodigde resolutie van het 4 cijfers postcodeniveau voor de berekeningen beschikbaar zijn. Door de benodigde aanpassingen van de invoerdata kan een deel van de variatie verloren gaan. Zo zijn koolstofgehaltes gemeten op 1152 locaties tijdens de CCNL-meetcampagne. In het model wordt het gemiddelde van de gemeten punten per bodemtype, landgebruik en regio genomen, zodat er aan elke postcode een koolstofgehalte kan worden toegekend. De onzekerheid in de invoergegevens is echter van minder belang voor deze studie, omdat we in deze studie kijken naar het verschil in $\mathrm{CO}_{2}$-vastlegging tussen de baseline en elke maatregel.

De berekeningen zijn gebaseerd op een procesmodel. Dit model is uitgebreid gekalibreerd en gevalideerd met de data uit de lange termijn Rothamsted-veldexperimenten. ${ }^{5}$ Nederland heeft niet genoeg langetermijnexperimenten (> 20 jaar) beschikbaar om het model te valideren met Nederlandse data. Omdat de Rothamsted-experimenten in dezelfde klimaatzone liggen als Nederland, achten we deze gegevens en kalibratie betrouwbaar voor de Nederlandse situatie.

Het RothC-model is een relatief simpel procesmodel met een beperkte hoeveelheid invoergegevens. Het voordeel hiervan is dat het model makkelijker is toe te passen op nationale schaal. Een nadeel is dat het model geen rekening kan houden met biogeochemische interacties tussen koolstof en stikstof en microbiële activiteit. Een model dat biogeochemische processen in meer detail meeneemt, is bijvoorbeeld het model Daycent of het DNDC-model. Deze modellen hebben echter weer veel meer invoergegevens nodig die vaak niet op nationale schaal beschikbaar zijn. Om de betrouwbaarheid van de modelberekeningen te vergroten, zou je het liefst een zogenaamde 'ensemble run' met meerdere modellen willen uitvoeren. Op deze manier kan het onderzoek beter een range aangeven waarbinnen de potentiële $\mathrm{CO}_{2}$-vastlegging van elke maatregel geschat wordt in plaats van één waarde toekennen voor die $\mathrm{CO}_{2}$-vastlegging zoals nu het geval is.

In deze studie was geen ruimte en tijd om ook een onzekerheidsanalyse uit te voeren en dat is wel een aanbeveling voor uitvoering in toekomstig onderzoek. Met een zogenaamde Monte-Carlo-analyse kan het effect van onzekerheden van de invoergegevens en aannames worden getoetst op het

\footnotetext{
${ }^{5}$ https://www.rothamsted.ac.uk/long-term-experiments
} 
uiteindelijke eindresultaat. Hierdoor kan dan ook een onzekerheidsmarge van de resultaten worden verkregen. De absolute waarde van de koolstofbalans is dan wel behoorlijk onzeker, maar het effect van een maatregel of meer maatregelen uitgedrukt in verschil tussen baseline zonder maatregel en een simulatie met maatregel heeft een aanmerkelijk lagere onzekerheid.

\section{Afwenteling}

Het verhogen van het organischestofgehalte heeft in veel gevallen ook een positief effect op andere bodem- en milieuaspecten. Toch kunnen bepaalde maatregelen zeker ook een negatief effect hebben op andere aspecten. In dit rapport wordt niet verder ingegaan op de mogelijke voordelen en afwenteling of nadelen die de bodemkoolstof maatregelen kunnen hebben op andere milieuaspecten. Het effect op lachgasemissie is wel bekeken, aangezien dit direct een effect heeft op het totale klimaatmitigatiepotentieel van een maatregel; zie hiervoor de review in hoofdstuk 6 . In andere rapporten is wel al eerder gekeken naar afwenteling: zie Lesschen et al. (2012) en het Slim Landgebruik-programma. 


\section{$4 \quad$ Koolstofvastlegging in biomassa in landschapselementen}

\subsection{Inleiding}

Naast $\mathrm{CO}_{2}$-vastlegging in bodems zijn er binnen de landbouw ook mogelijkheden voor $\mathrm{CO}_{2}$-vastlegging in biomassa. Bijvoorbeeld door het aanleggen van landschapselementen. Landschapselementen zijn natuurlijke vegetaties in het landschap die van oudsher onder andere dienden als perceelscheiding, veekering of (hak)houtwinning. Echter, door de komst van het prikkeldraad, de schaalvergroting en ruilverkaveling zijn vele hectaren landschapselementen verloren gegaan. Nederland kent verschillende typen landschapselementen, zoals houtwallen, elzensingels, bomenrijen, griendjes, struweelhagen en natuurvriendelijke oevers. Ze bepalen in sommige delen van Nederland de identiteit van een streek en de structuur van het landschap. Landschapselementen hebben een cultuurhistorische waarde die velen graag willen behouden. Daarnaast vervullen landschapselementen verschillende ecosysteemdiensten en vertegenwoordigen ze een relatief hoge natuurwaarde, zeker in een landbouwomgeving. De natuurlijke vegetatie zorgt ook voor een hoge C-voorraad in de biomassa in de opstand.

Landschapselementen liggen niet alleen naast landbouwpercelen, maar ook langs bijvoorbeeld (water)wegen en het spoor. In deze studie zijn we alleen geïnteresseerd in de elementen die langs landbouwpercelen liggen, omdat we willen weten hoeveel $\mathrm{C}$ deze elementen momenteel vastleggen en wat er extra aan $\mathrm{CO}_{2}$-vastlegging gerealiseerd kan worden als er delen van een landbouwperceel ingericht worden als landschapselement. Nederland telt 1,84 miljoen ha aan landbouwareaal en er grenst zo'n 4078 ha landschapselement aan landbouwarealen, ofwel 0,22\%. Het doel van dit hoofdstuk in deze studie geeft een benadering van de huidige koolstofvoorraad (C-voorraad) en de extra $\mathrm{CO}_{2}$-vastlegging die landschapselementen aangrenzend aan landbouwarealen zouden kunnen leveren als 1 of $2 \%$ van het landbouwareaal omgezet wordt naar landschapselementen en er dus 5-10 keer zoveel landschapselementen komen. De uitkomsten worden gespiegeld aan de doelstelling van de overheid om 0,4-0,6 Mton $\mathrm{CO}_{2} /$ jaar extra $\mathrm{CO}_{2}$ vast te leggen in landbouwgrond en 0,4-0,8 Mton $\mathrm{CO}_{2}$ in bomen, bos en natuur in 2030.

\subsection{Aanpak}

Hoeveel areaal aan landschapselement er momenteel aanwezig is, kan uitgerekend worden aan de hand van data uit de Basisregistratie Gewaspercelen (2018). Het areaal landbouwpercelen staat geregistreerd in het databestand Agrarisch Areaal Nederland (RVO, 2016). Door deze twee databronnen te combineren, weten we het aandeel landbouwpercelen en landschapselementen aangrenzend aan landbouwpercelen. Vervolgens gaan we de C-voorraad van de landschapselementen aangrenzend aan landbouwpercelen berekenen. De Boer en Oosterbaan (2004) hebben onderzocht hoeveel biomassa de landschapselementen 'elzensingel' en 'houtwal' opleveren. Gezien de data kan aangenomen worden dat beide landschapselementen na vijftien jaar volgroeid en in evenwicht zijn. Elzensingels en houtwallen van vijftien jaar of ouder hebben respectievelijk een gemiddelde droge stof (ds) biomassa van 0,35 ton ds/m en 0,20 ton ds/m (droge stof per strekkende meter). Over het algemeen vind je elzensingels op plekken waar de grondwaterstand hoog is en houtwallen op plekken waar de grondwaterstand laag is. We veronderstellen dat een landschapselement een gemiddelde biomassa van 0,28 ton ds/m opbouwt in vijftien jaar als het element zowel onder hoge als lage grondwaterstanden voor kan komen (bijv. griendje, knotboom). We categoriseren alle landschapselementen aan de hand van deze drie categorieën, met uitzondering van de elementen natuurvriendelijke oever, rietzoom en klein rietperceel. Hiervoor gebruiken we de biomassa zoals die berekend is in Lesschen et al. (2012). Verder nemen we aan dat de elementen poel en klein historisch water, water en wandelpad over boerenland geen bijdrage aan koolstofvastlegging leveren. 
De Boer en Oosterbaan (2004) berekenen de biomassa van elzensingels en houtwallen in ton droge stof per meter. Gegevens over de breedte van landschapselementen zijn nodig om de biomassa per meter om te rekenen naar hectare. De gemiddelde breedte per landschapselement wordt berekend aan de hand van Formule 1 . Hierbij wordt ervan uitgegaan dat landschapselementen rechthoekig zijn.

$$
\text { Breedte }=\frac{\text { omtrek }-\operatorname{sqrt}\left(\mid \text { omtrek }^{2}-16 * O p p \cdot \mid\right)}{4}
$$

Bij de berekening wordt ervan uitgegaan dat alle landschapselementen in Nederland volgroeid zijn (> 15 jaar). De droge stof in biomassa wordt vermenigvuldigd met 0,5 om tot een C-voorraad te komen. De maximale voorraad die aan landschapselementen wordt toegekend, is gemaximeerd op $200 \mathrm{t} \mathrm{C/ha}$. Deze waarde is gebaseerd op de maximale C-voorraad in een bos (Nabuurs en Verkaik, 1999). Om vervolgens uit te rekenen hoeveel $\mathrm{CO}_{2}$ volgroeide landschapselementen per jaar kunnen vastleggen, wordt de C-voorraad gedeeld door 15 jaar en vermenigvuldigd met 44/12 (molmassa $\mathrm{CO}_{2}$ molecuul/molmassa C-atoom). De tabel in Bijlage 2 geeft een overzicht van de C-voorraad en $\mathrm{CO}_{2}-$ vastlegging per landschapselement.

De $\mathrm{CO}_{2}$-vastlegging en de $\mathrm{C}$-voorraad kunnen toenemen als er een gedeelte van het landbouwareaal ingericht wordt als landschapselement. Hoeveel dit is, wordt berekend aan de hand van twee scenario's: tot 1 of $2 \%$ van het landbouwareaal wordt ingericht als landschapselement. De keuze voor deze percentages is subjectief, aangezien er op dit moment nog geen specifieke doelstellingen zijn opgenomen voor een areaal landschapselementen. Op postcodeniveau wordt het huidige aandeel landschapselementen aangevuld tot 1 of $2 \%$ van het landbouwareaal. Als dit aandeel al 1 of $2 \%$ is, zal er geen extra landbouwgrond ingericht worden als landschapselement. Van het huidige areaal landschapselementen wordt een gemiddelde C-voorraad berekend. Een aantal landschapselementen draagt niet direct bij aan C-vastlegging, zoals poel en klein historisch water, wandelpad over boerenland en water. Deze elementen worden dan ook niet meegenomen in het berekenen van de gemiddelde C-voorraad die landschapselementen kunnen leveren. Om tot een areaalbedekking van 1 of $2 \%$ te komen, is dit gemiddelde gebruikt om de extra C-voorraad te bepalen. Als de extra Cvoorraad berekend is, kan de extra $\mathrm{CO}_{2}$-vastlegging per ha landbouwgrond per jaar berekend worden. Hierbij wordt uitgegaan van een periode van vijftien jaar waarin nettovastlegging van $\mathrm{CO}_{2}$ plaatsvindt, aangezien na die periode een evenwicht bereikt wordt tussen aangroei en oogst van hout uit de landschapselementen.

\subsection{Resultaat}

In het Klimaatakkoord is het streven naar een extra vastlegging van 0,4-0,8 Mton $\mathrm{CO}_{2}$ per jaar in 2030 in bomen, bos en natuur. Nederland telt 1,84 $\mathrm{mln}$. ha landbouwgrond. Hiervan is nu ongeveer $0,2 \%$ ingericht als landschapselement (4078 ha). Geïsoleerde bomen, struweelrand en struweelhaag zijn de landschapselementen die het grootste oppervlak bestrijken (Figuur 13). Gebaseerd op het areaal aan landschapselement en de C-voorraad per landschapselement, bedraagt de gemiddelde Cvoorraad van landschapselementen in Nederland 104 t C/ha landschapselement. 


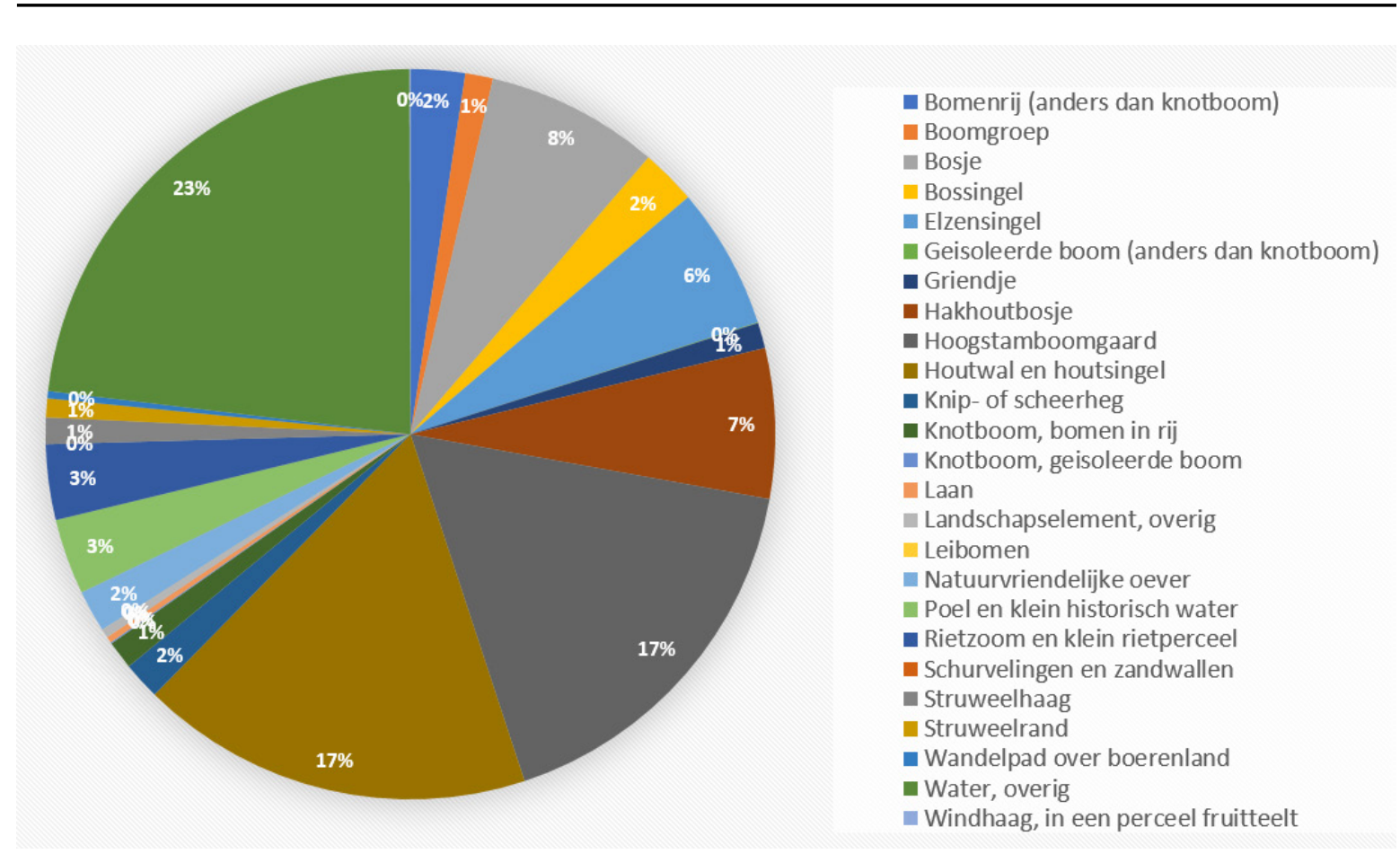

Figuur 13 De areaalbedekking van landschapselementen in Nederland (in \%).

Als het areaal landschapselementen uitgebreid wordt tot 1 of $2 \%$ van het landbouwareaal, dan kan dat tot een extra $\mathrm{CO}_{2}$-vastlegging van $400 \mathrm{kton} / \mathrm{jaar}$ leiden en als het tot $2 \%$ van het landbouwareaal wordt uitgebreid, kan dit leiden tot een extra $\mathrm{CO}_{2}$-vastlegging van 870 kton $\mathrm{CO}_{2} /$ jaar. Regionaal zien we dat de huidige landschapselementen de hoogste C-voorraad hebben in Midden-Friesland, de Achterhoek en Zuid-Limburg. In deze gebieden is vaak al 1 tot $2 \%$ van het landbouwareaal ingericht als landschapselement. De extra $\mathrm{CO}_{2}$-vastlegging moet daarom niet in deze gebieden gezocht worden, maar juist in de gebieden waar weinig landschapselementen zijn maar wel veel landbouwareaal. Deze gebieden vind je voornamelijk in Groningen, het westen van Friesland, Flevoland en het noorden van Noord-Holland (Figuur 14). De vraag is wel in hoeverre in deze gebieden het open cultuurlandschap behouden moet blijven. 

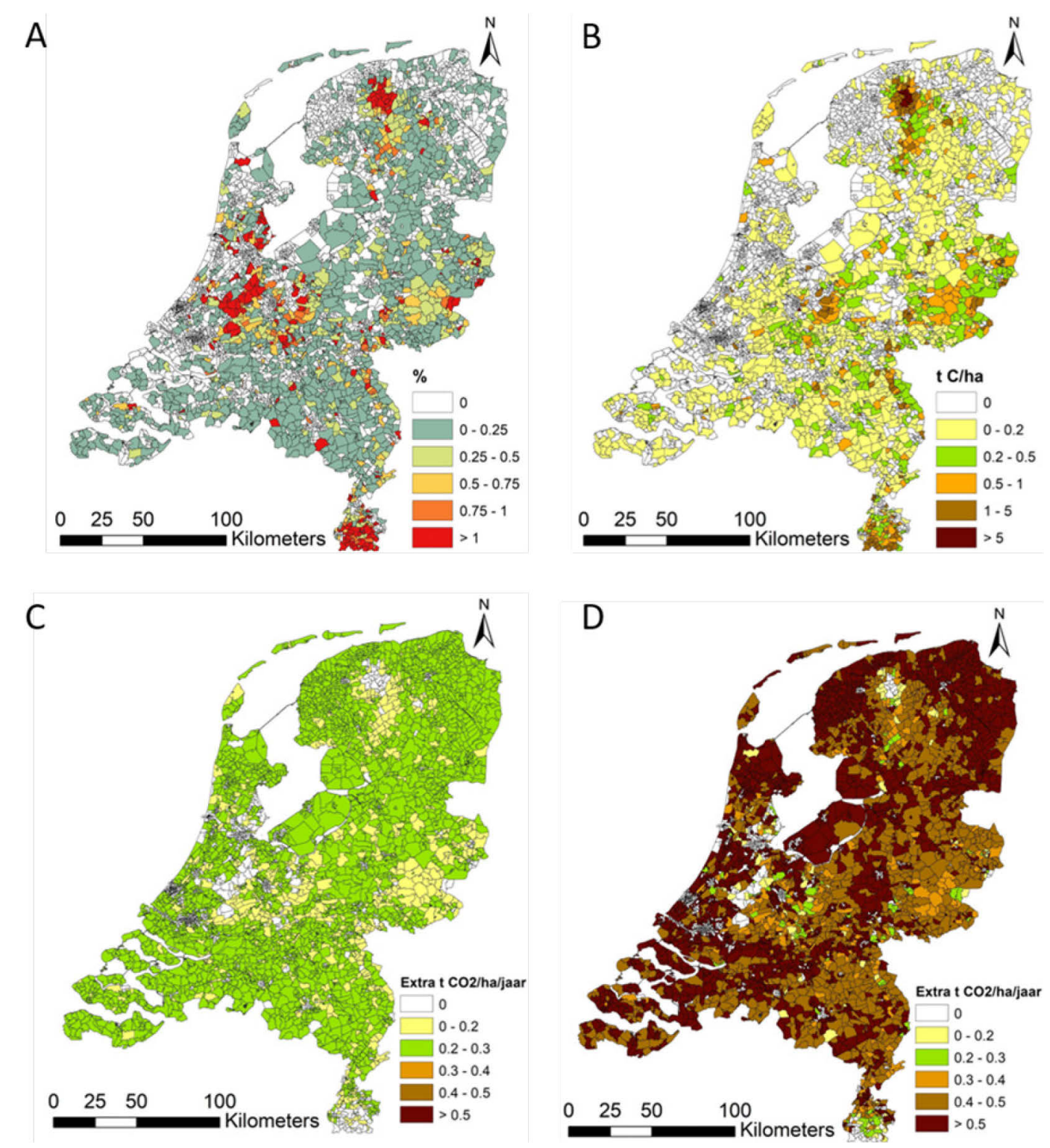

Figuur 14 Huidig aandeel landschapselementen (in \% t.o.v. het totale landbouwareaal) (A), de huidige $C$-voorraad (per ha landbouwgrond) in landschapselementen $(B)$ en de extra $\mathrm{CO}_{2}$-vastlegging per ha landbouwgrond die gerealiseerd kan worden als $1 \%(C)$ of $2 \%(D)$ van het landbouwareaal als landschapselement gaat dienen.

\subsection{Conclusie}

Landschapselementen kunnen potentieel een grote bijdrage leveren aan de doelstelling voor extra koolstofvastlegging in landgebruik. Als het aandeel landschapselement aangevuld zou worden tot $1 \%$ van het landbouwareaal, dan betekent dat een potentiële $\mathrm{CO}_{2}$-vastlegging van 0,4 Mton $\mathrm{CO}_{2}$ per jaar. Dit vergt echter wel een behoorlijke inspanning t.o.v. de huidige situatie met een verviervoudiging van het huidige areaal landschapselementen (van ongeveer 4000 ha naar 18000 ha). De koolstofvastlegging is wel van tijdelijke aard, aangezien de gemiddelde leeftijd 15 jaar is; na deze periode zal er ruwweg een evenwicht zijn tussen aangroei en oogst van de biomassa. Dit is een veel kortere periode dan geldt voor koolstofvastlegging in bos of bodem. Wel kunnen landschapselementen daarna nog bijdragen aan vervanging van fossiele brandstoffen door het gebruik van geoogste biomassa voor bio-energie. Landschapselementen dragen, naast het produceren van biomassa en het vastleggen van koolstof, ook bij aan de cultuurhistorische waarde van ons landschap en aan verschillende ecosysteemdiensten (bv. het stimuleren van de biodiversiteit). Landschapselementen worden vaak om deze reden aangelegd, waardoor extra koolstofvastlegging gezien kan worden als een bijkomend voordeel. 


\section{$5 \quad$ Koolstofvastlegging in agroforestry- systemen}

\section{$5.1 \quad$ Inleiding}

In Nederland spreken we van agroforestry wanneer houtige, meerjarige gewassen zoals bomen en struiken bewust een onderdeel uitmaken van de akkerbouw, groenteteelt en/of de veehouderij. Dit betekent dat houtige gewassen worden geteeld op hetzelfde perceel als waar de gewassen worden verbouwd en/of de weide wordt begraasd of gemaaid. De houtige gewassen kunnen voor meerdere doeleinden worden aangeplant, zoals de productie van fruit, noten of hout (Norén \& Keur, 2019). Agroforestry kan op vele manieren worden toegepast.

In Nederland kennen we een viertal vormen van agroforestry:

- Silvopastorale systemen, waarbij een combinatie wordt gemaakt van productief grasland en vee met bomen of struiken;

- Rijenteeltsystemen, waarbij een combinatie wordt gemaakt van akkerbouw, vollegrondsgroenteteelt of fruitproductie met bomen en struiken;

- Windhagen, waarbij een haag wordt geplaatst bij grasland of bouwland om de wind te breken;

- Voedselbosbouw, waarbij een teeltsysteem wordt gecreëerd dat bestaat uit verschillende vegetatielagen voor de productie van o.a. fruit, noten, groenten, kruiden en zaden (Luske et al. 2020).

\section{$5.2 \quad$ Literatuuronderzoek}

Er wordt aangenomen dat agroforestry-systemen kunnen bijdragen aan klimaatmitigatie, doordat koolstof wordt vastgelegd in het systeem. $\mathrm{CO}_{2}$ wordt vastgelegd in de boombiomassa en in de bodem (Peichl et al., 2006). Een literatuuronderzoek naar koolstofvastlegging in agroforestry-systemen in gematigde klimaatzones toont een gemiddelde koolstofvastlegging van 4,19 ton $\mathrm{CO}_{2} /$ ha/jaar voor rijenteeltsystemen (Tabel 7). Voor silvopastorale systemen is de gemiddelde koolstofvastlegging 3,26 ton $\mathrm{CO}_{2} /$ ha/jaar. Voedselbossen leggen gemiddeld 4,75 ton $\mathrm{CO}_{2}$ ha/jaar vast. Het onderzoek heeft aangetoond dat vastlegging gemiddeld het hoogst is in rijenteeltsystemen in voedselbossen. Ma et al. (2020) vinden in een wereldwijde meta-analyse geen bewijs voor koolstofvastlegging in de bodem bij silvopastorale systemen t.o.v. conventioneel grasland. Ook De Stefano \& Jacobson (2018) tonen dat het effect van silvopastorale systemen op koolstofvastlegging kleiner is dan voor rijenteeltsystemen. Dit wordt onder andere veroorzaakt doordat de input van organisch materiaal uit graswortels hoger is dan uit bomen, waardoor er meer recalcitrant materiaal wordt aangevoerd door grasbiomassa dan door boombiomassa (Ma et al. 2020; De Stefano \& Jacobson, 2018). Het literatuuronderzoek laat ook zien dat er nog relatief weinig gegevens beschikbaar zijn over de potentie van koolstofvastlegging d.m.v. agroforestry. Met name onderzoek naar koolstofvastlegging in voedselbossen is schaars. Om een inschatting te kunnen geven van bodemkoolstofvastlegging in voedselbossen is aangenomen dat vastlegging in voedselbossen vergelijkbaar is met vastlegging bij herbebossing. 
Tabel 7 Resultaten literatuuronderzoek naar koolstofvastlegging in verschillende agroforestrysystemen in Nederland.

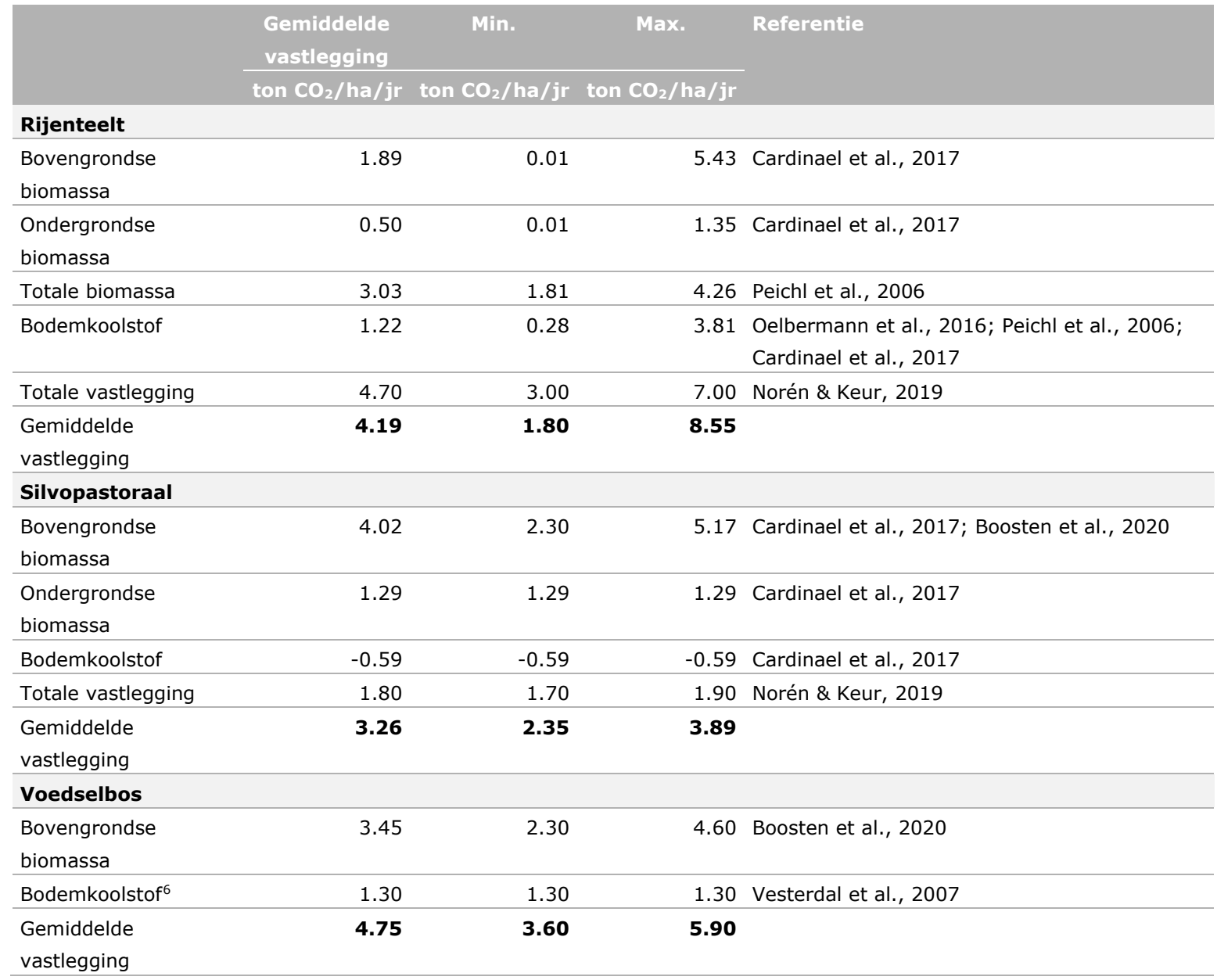

\subsection{Potentie voor C-vastlegging in Nederland}

In Nederland geldt het streven om in 203025.000 hectare landbouwgrond in te richten als agroforestry (Luske et al., 2020), waarvan 1000 ha in de vorm van voedselbossen. Overige vormen van agroforestry die als kansrijk worden gezien voor de invulling van de 25.000 ha zijn rijenteelt in de akkerbouw en silvopastorale systemen in de melkveehouderij. In het Masterplan Agroforestry wordt de volgende invulling gegeven aan de 25.000 ha:

- 10.000 ha gebiedsgerichte aanpak

- 7.000 ha silvopastorale systemen veehouderij

- 4.500 ha rijenteelt

- 2.000 ha kippenuitloop met bomen

- 1.000 ha voedselbos

- 500 ha overig

Voor de schatting van de potentiële koolstofvastlegging in agroforestry-systemen is deze indeling versimpeld naar 9750 ha in de vorm van rijenteelt, 14250 ha in de vorm van silvopastorale systemen en 1000 ha voedselbossen. Bij een realisatie van deze arealen agroforestry in 2030 zal dat leiden tot

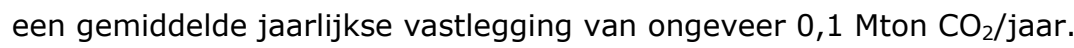

Naast een bijdrage aan koolstofvastlegging in de biomassa en bodem, draagt agroforestry ook bij aan de bodemkwaliteit. Kim et al. (2016) vinden in een synthese dat de bulkdichtheid van de bodem onder agroforestry afneemt. Dit levert een positieve bijdrage aan het herstellen en verminderen van eerdere

6 Gebaseerd op koolstofvastlegging bij herbebossing van akkerland. 
bodemverdichting. Daarnaast zorgen de aanwezige houtige gewassen voor lagere windsnelheden waardoor bodemerosie afneemt, verbetert de bodemstructuur waardoor water beter wordt opgenomen door de bodem en bieden de houtige gewassen bescherming aan onderliggende gewassen tijdens weersextremen.

Onderzoek naar $\mathrm{N}_{2} \mathrm{O}$ - en $\mathrm{CH}_{4}$-emissies uit agroforestry-systemen is schaars. Verschillende studies rapporteren dat $\mathrm{N}_{2} \mathrm{O}$-emissies toenemen onder agroforestry-systemen, wat mogelijk kan ontstaan door de grotere aanvoer van stikstof door stikstof-fixerende gewassen (Kim et al., 2016).

Daarentegen kan aanvoer van stikstof worden verlaagd in agroforestry-systemen op die (onder)delen die bezet zijn door bomen. Tegelijk kunnen de bomen het overschot aan stikstof opnemen en dat vermindert de verliezen en de $\mathrm{N}$ - en $\mathrm{N}_{2} \mathrm{O}$-emissies (Schoeneberger et al., 2012). Baah-Acheamfour et al. (2017) tonen in hun review dat $\mathrm{N}_{2} \mathrm{O}$-emissies juist afnemen onder agroforestry. De resultaten tonen daarmee dat agroforestry positief bijdraagt aan het klimaatprobleem, maar onderzoek naar het vastleggen van koolstof en $\mathrm{N}_{2} \mathrm{O}$-emissies is nog zeer schaars. 


\section{$6 \quad$ Koolstofvastlegging en lachgasemissie}

\subsection{Inleiding}

De opslag van koolstof in landbouwgronden is een van de maatregelen die de Nederlandse overheid wil nemen om broeikasgasemissies te beperken. Het verhogen van het organischestofgehalte in de bodem heeft ook effect op de stikstofkringloop en daarmee op de emissie van het broeikasgas lachgas $\left(\mathrm{N}_{2} \mathrm{O}\right)$. Lachgas wordt gevormd tijdens de microbiële processen nitrificatie en denitrificatie in de bodem, water en andere bronnen waar stikstofomzettingen plaatsvinden (bijvoorbeeld compostering).

Lachgas is een sterk broeikasgas; de Global Warming Potential (GWP7) van $\mathrm{N}_{2} \mathrm{O}$ is 265 maal hoger per molecuul dan die van $\mathrm{CO}_{2}$ op een tijdschaal van 100 jaar (IPCC, 2013). De concentratie van $\mathrm{N}_{2} \mathrm{O}$ is echter veel lager (ongeveer een factor 1000) dan $\mathrm{CO}_{2}$, waardoor het totale broeikaseffect van $\mathrm{CO}_{2}$ groter is ( $64 \%$ van het mondiale broeikasgaseffect) dan van $\mathrm{N}_{2} \mathrm{O}$ ( $6 \%$ van totaal). Lachgas is niet alleen een broeikasgas, maar ook een gas dat de ozonlaag aantast. Na het uitfaseren van chloorfluorkoolstofverbindingen in het kader van het Montreal Protocol is $\mathrm{N}_{2} \mathrm{O}$-emissie de belangrijkste emissiebron die leidt tot afbraak van de ozonlaag (Ravishankara et al., 2009; Wuebbles, 2009).

Nederland hanteert een land-specifieke methode om $\mathrm{N}_{2} \mathrm{O}$-emissie uit de landbouw te berekenen; deze methode is opgenomen in het NEMA-model (National Emission Model Agriculture; (Bruggen et al., 2018; Vonk et al., 2018). De $\mathrm{N}_{2} \mathrm{O}$-emissie uit de landbouw heeft een aandeel van $2,8 \%$ van de totale emissie van $\mathrm{CO}_{2}$ - en niet- $\mathrm{CO}_{2}$-broeikasgassen in Nederland (Ruyssenaars et al., 2020).

Het is belangrijk om inzicht te hebben in de effecten van (veranderingen in) de hoeveelheid organische stof in landbouwgronden op $\mathrm{N}_{2} \mathrm{O}$-emissie, omdat een toename van de $\mathrm{N}_{2} \mathrm{O}$-emissie de effectiviteit van koolstofopslag voor mitigatie van broeikasgasemissies kan verlagen of mogelijk zelfs tenietdoen. In dit hoofdstuk worden de resultaten van een literatuurstudie naar effecten van organische stof op $\mathrm{N}_{2} \mathrm{O}$-emissie beschreven. Er wordt zowel gekeken naar het effect van toediening van organische meststoffen en gewasresten als naar het effect van organische stof in de bodem op $\mathrm{N}_{2} \mathrm{O}$-emissie. Sommige organische meststoffen, met name dierlijke mest, bevatten gemakkelijk afbreekbare organische stof die tijdelijk kan leiden tot een hoge $\mathrm{N}_{2} \mathrm{O}$-emissie. De organische stof in de bodem bestaat uit een mengsel van organische verbindingen van verschillende herkomst, leeftijd en afbreekbaarheid met mogelijk een verschillend effect op $\mathrm{N}_{2} \mathrm{O}$-emissie.

Veeljarige toediening van stikstofhoudende organische stof kan resulteren tot ophoping van organische stikstof en dit kan het risico op nitraatuitspoeling verhogen. Nitraat dat uitspoelt en in (grond)water terechtkomt, is daar een bron van zogenaamde indirecte $\mathrm{N}_{2} \mathrm{O}$-emissie. ${ }^{8}$ Mocht de opslag van koolstof in landbouwgronden leiden tot een toename van nitraatuitspoeling, dan leidt dit ook tot een toename van indirecte $\mathrm{N}_{2} \mathrm{O}$-emissie.

\subsection{Processen in bodem waarbij lachgas wordt gevormd}

Lachgas wordt in de bodem gevormd tijdens de biologische processen nitrificatie en denitrificatie en koppelingen van deze processen, zoals nitrifier denitrification (het proces waarbij nitrificerende bacteriën onder zuurstofloze omstandigheden denitrificeren). Naast vorming tijdens biologische processen, kan $\mathrm{N}_{2} \mathrm{O}$ worden geproduceerd tijdens chemische denitrificatie.

\footnotetext{
7 GWP geeft het aardopwarmingsvermogen van $1 \mathrm{~kg}$ van een gas aan over een bepaalde periode (bv. 100 jaar), relatief ten opzichte van $1 \mathrm{~kg}$ of $\mathrm{CO}_{2}$.

${ }^{8} \mathrm{Er}$ wordt aangenomen dat het uitgespoelde nitraat ooit ergens denitrificeert en dat daarbij lachgas wordt gevormd.
} 


\subsubsection{Nitrificatie}

Nitrificatie is de oxidatie van ammonium $\left(\mathrm{NH}_{4}{ }^{+}\right)$tot nitriet $\left(\mathrm{NO}_{2}^{-}\right)$en nitraat $\left(\mathrm{NO}_{3}^{-}\right)$; zie Figuur 15 (Hynes \& Knowles, 1984). Bacteriën die ammonium omzetten tot nitriet behoren tot de geslachten Nitrosomonas en Nitrosospira en bacteriën die nitriet omzetten tot nitraat, behoren tot het geslacht Nitrobacter. Nitrificatie treedt op onder zuurstofrijke omstandigheden. De nitrificerende bacteriën zijn autotrofe bacteriën en gebruiken $\mathrm{CO}_{2}$ als koolstofbron. Nitrificerende bacteriën hebben geen organische stof nodig voor groei. Lachgas is een bijproduct van nitrificatie en wordt geproduceerd onder omstandigheden waarin nitrificatie wordt geremd; bijvoorbeeld onder relatief zuurstofarme omstandigheden.

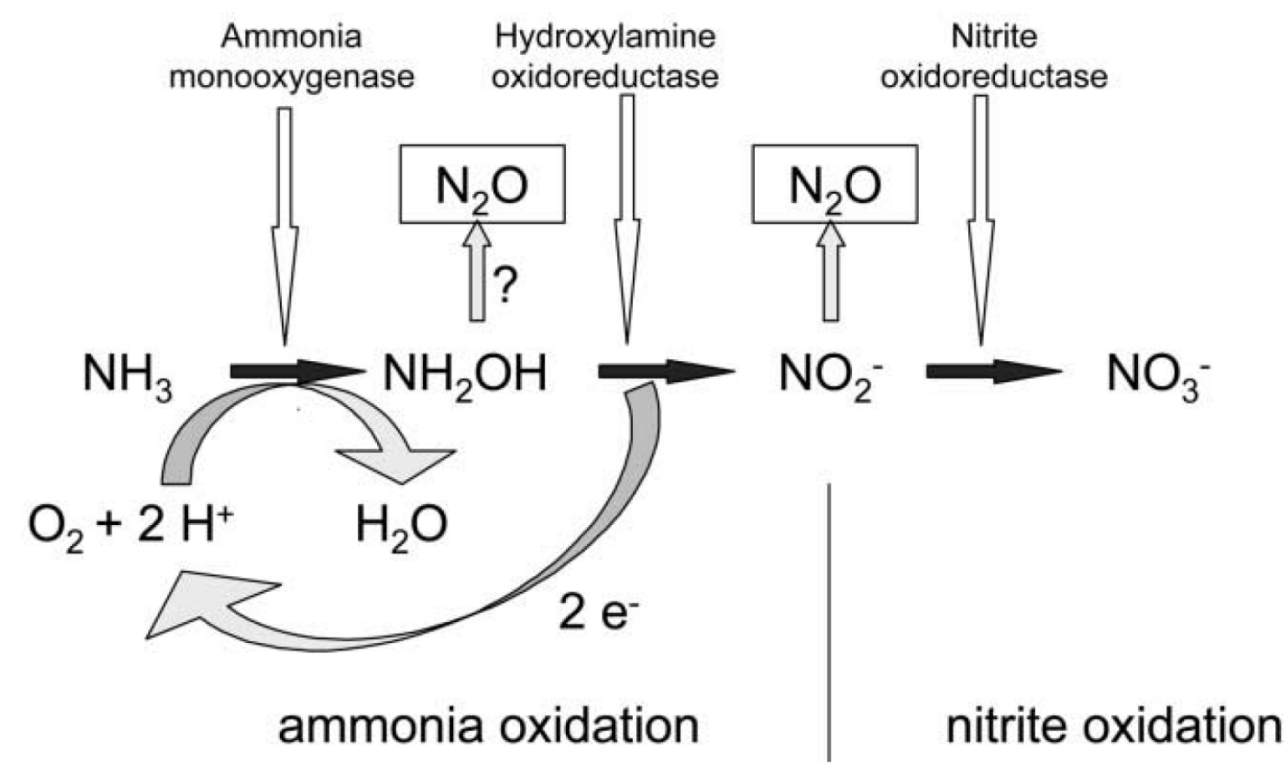

Figuur 15 Stikstofomzettingen tijdens het proces nitrificatie (Wrage et al., 2001).

\subsubsection{Biologische denitrificatie}

Denitrificerende bacteriën produceren $\mathrm{N}_{2} \mathrm{O}$ onder zuurstofloze omstandigheden tijdens de stapsgewijze reductie van nitriet tot stikstofgas $\left(\mathrm{N}_{2}\right)$; zie Figuur 16. De meeste denitrificerende bacteriën zijn heterotrofe bacteriën en gebruiken organische stof als koolstofbron. Gemakkelijk afbreekbare organische stof is voor de meeste denitrificerende bacteriën de energiebron (Firestone, 1982; Firestone et al., 1989). Sommige bacteriën gebruiken pyriet $\left(\mathrm{FeS}_{2}\right)$ als energiebron. Tijdens denitrificatie worden verschillende (intermediaire) verbindingen geproduceerd: nitriet, stikstofoxide oxide (NO), $\mathrm{N}_{2} \mathrm{O}$ en $\mathrm{N}_{2}$. Hierbij zijn verschillende enzymen (reductasen) betrokken. In tegenstelling tot nitrificatie, waarin $\mathrm{N}_{2} \mathrm{O}$ als bijproduct kan worden gevormd, is $\mathrm{N}_{2} \mathrm{O}$ een tussenproduct in denitrificatie. De mate van omzetting van $\mathrm{N}_{2} \mathrm{O}$ naar $\mathrm{N}_{2}$ bepaalt uiteindelijk hoeveel $\mathrm{N}_{2} \mathrm{O}$ er naar de atmosfeer kan ontsnappen. $\mathrm{Er}$ is een groot aantal bacteriesoorten in staat om te denitrificeren, zoals de taxa Pseudomonas, Bacillus, Thiobacillus en Propionibacterium (Firestone, 1982). Deze bacteriën zijn onder zuurstofloze omstandigheden in staat om nitraat in plaats van zuurstof te gebruiken voor hun metabolisme. Naast bacteriën zijn ook bepaalde schimmelsoorten in staat om te denitrificeren (Matsuoka et al., 2017). 


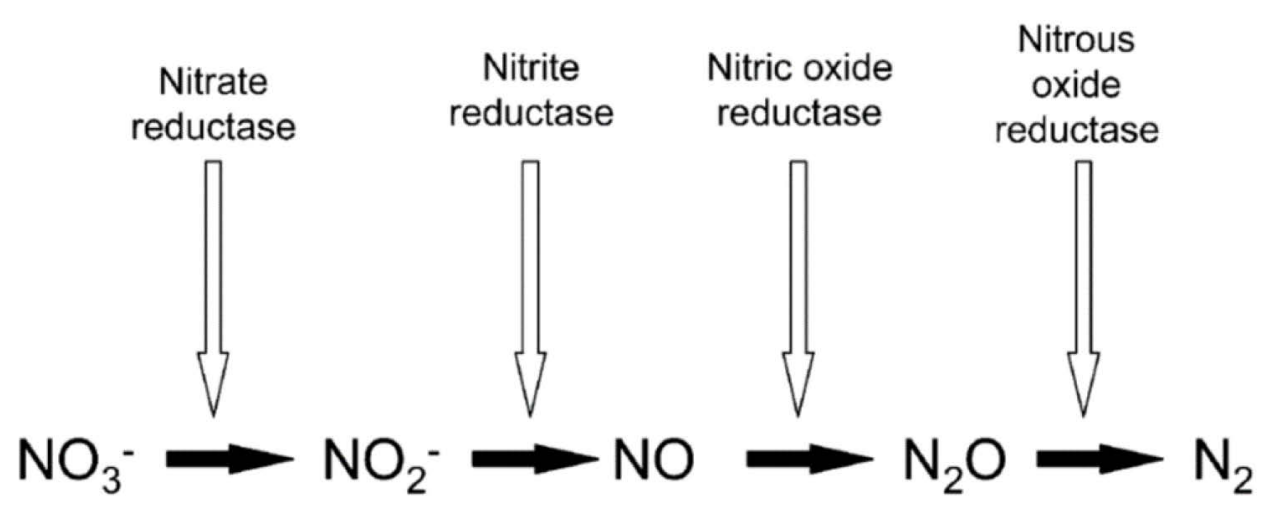

Figuur 16 Stikstofomzettingen tijdens het proces biologische denitrificatie (Wrage et al., 2001).

\subsubsection{Chemische denitrificatie}

Chemische denitrificatie is het proces waarbij nitriet en hydroxylamnine $\left(\mathrm{NH}_{2} \mathrm{OH}\right)$ chemisch worden gereduceerd tot $\mathrm{N}_{2} \mathrm{O}$ (Chalk and Smith, 1983; Heil et al., 2016). In de meeste landbouwgronden wordt nitriet snel omgezet in nitraat, waardoor er geen nitriet accumuleert. Onder alkalische omstandigheden (hoge $\mathrm{pH}$ ) in aanwezigheid van ammonium wordt ammoniak $\left(\mathrm{NH}_{3}\right)$ gevormd. Ammoniak is toxisch voor de Nitrosomonas bacteriën, de bacteriën die nitriet omzetten in nitraat. Bij gebruik van ureummeststoffen, toediening van ammoniummeststoffen aan kalkrijke grond en in urineplekken kan de pH lokaal in de bodem hoog oplopen en ammoniaktoxiciteit optreden. Onder deze omstandigheden kan nitriet accumuleren en kan chemische denitrificatie optreden.

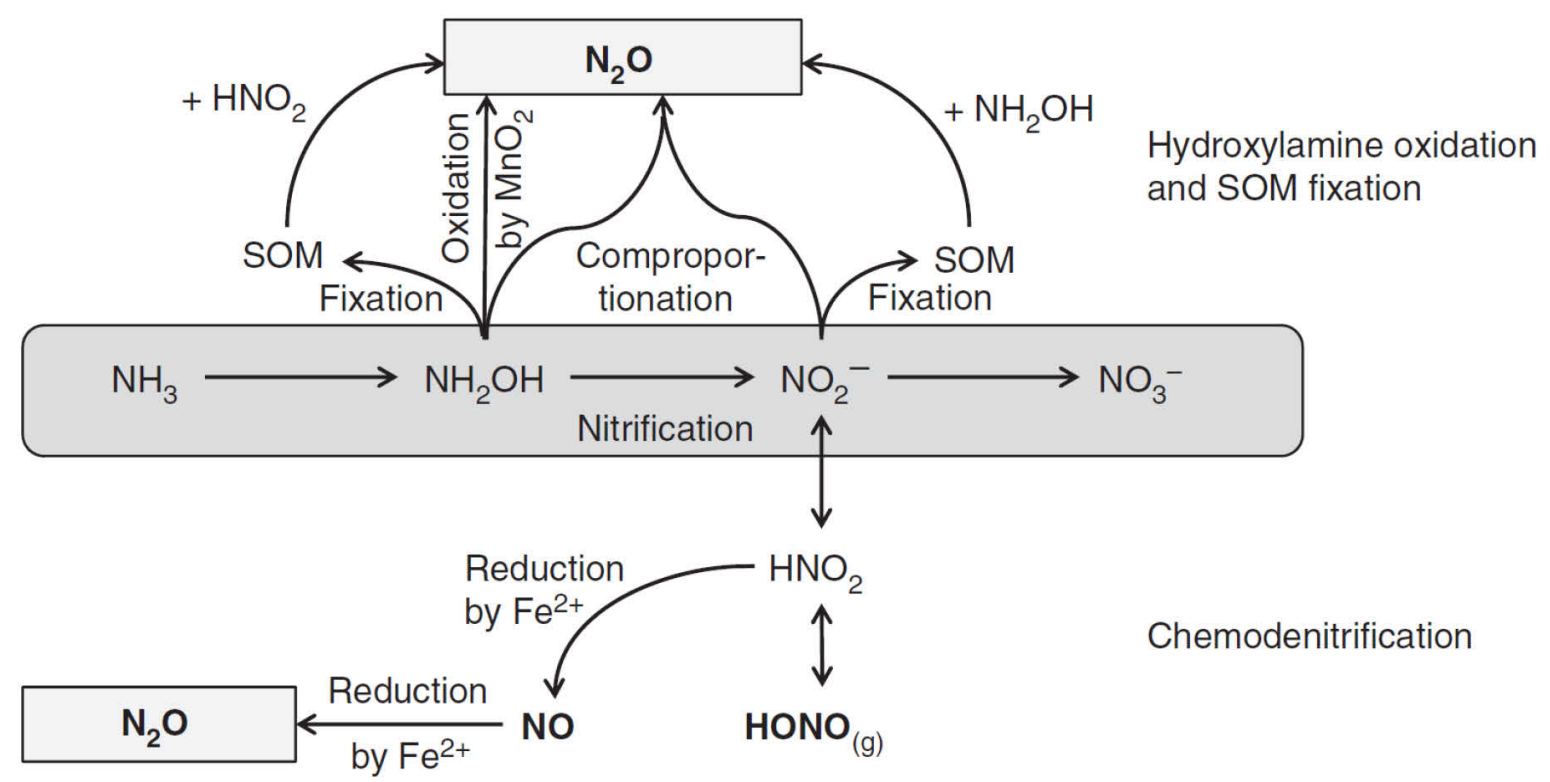

Figuur 17 Stikstofomzettingen tijdens het proces chemische denitrificatie (Heil et al., 2016).

\subsubsection{Nitrifier denitrification}

Sommige nitrificerende bacteriën kunnen ook denitrificeren (Wrage et al., 2001; Wrage-Monnig et al., 2018); zie Figuur 18. Er zijn nog veel onduidelijkheden over het belang van dit proces. Nitrifier denitrification lijkt vooral op te treden bij hoge ammoniumconcentraties, lage zuurstofgehalten en lage gehalten aan organische stof. 


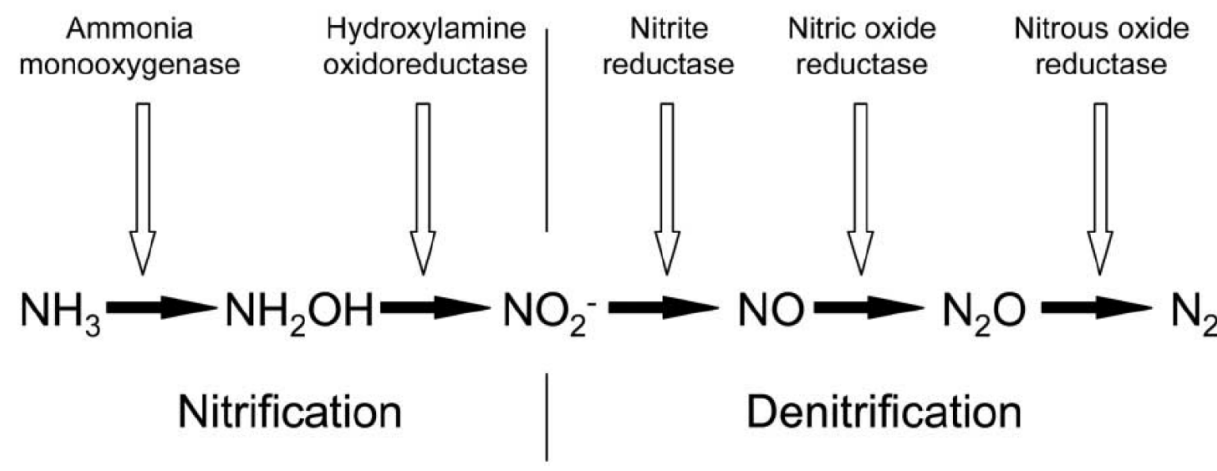

Figuur 18 Stikstofomzettingen tijdens het proces nitrifier denitrification (Wrage et al., 2001).

\subsubsection{Bijdrage van de verschillende processen aan lachgasemissie}

Uit de vorige paragrafen blijkt dat er verschillende processen en een groot aantal micro-organismen een rol spelen bij de productie (en consumptie) van $\mathrm{N}_{2} \mathrm{O}$ in de bodem. De bijdrage van de verschillende processen aan de totale $\mathrm{N}_{2} \mathrm{O}$-emissie is moeilijk aan te geven en is ook afhankelijk van de omstandigheden ter plaatse, zoals het gehalte aan zuurstof (aerobie versus anaerobie), voorkomen van nitraat, ammonium en organische stof, de temperatuur en de $\mathrm{pH}$ van de bodem. Om de processen te ontrafelen, is een combinatie van meetmethoden nodig, zoals het gebruik van remmers en isotopen. Verschillende studies geven aan dat $50-100 \%$ van de $\mathrm{N}_{2} \mathrm{O}$-emissie afkomstig is van denitrificatie en nitrifier-denitrification (Wrage et al., 2001; Wrage-Monnig et al., 2018).

Metingen van $\mathrm{N}_{2} \mathrm{O}$-emissie uit grasland laat een veel hogere $\mathrm{N}_{2} \mathrm{O}$-emissie en denitrificatie zien van nitraatmeststoffen dan meststoffen met alleen ammonium onder natte omstandigheden (Velthof et al., 1996; Clayton et al., 1997; Smith et al., 2012; Harty et al., 2016). Dit geeft aan dat denitrificatie de belangrijkste bron is van lachgas onder deze omstandigheden. Een belangrijke factor hierbij is waarschijnlijk het hoge gehalte aan toegankelijke en afbreekbare organische stof in grasland, bijvoorbeeld uit wortels en exudaten. Hierdoor kan grasland een hoge denitrificatiecapaciteit hebben (zie ook Figuur 21).

Metingen van $\mathrm{N}_{2} \mathrm{O}$-emissie uit bouwland laten vaak relatief kleine verschillen zien tussen meststoftypen (Smith et al., 2012; Bell et al., 2015). Soms is de emissie uit ureum en ammoniummeststoffen hoger dan uit nitraathoudende meststoffen, met name onder droge omstandigheden en bij lage emissies (Lebender et al., 2014). Dit duidt erop dat nitrificatie onder deze omstandigheden een belangrijke $\mathrm{N}_{2} \mathrm{O}$-bron is. Ureum leidt tot hoge concentraties ammoniak en remming van nitrificerende bacteriën, zodat ook chemische denitrificatie een bron van $\mathrm{N}_{2} \mathrm{O}$ kan zijn.

Uit de literatuur komt het beeld naar voren dat de hoogste $\mathrm{N}_{2} \mathrm{O}$-emissie optreedt tijdens natte omstandigheden en dat dan denitrificatie en nitrifier-denitrification de belangrijkste bronnen van $\mathrm{N}_{2} \mathrm{O}$ zijn. Onder relatief droge omstandigheden is nitrificatie een belangrijke bron, maar $\mathrm{N}_{2} \mathrm{O}$-emissie is onder deze omstandigheden duidelijk lager dan onder natte omstandigheden. Het is aannemelijk dat denitrificatie over een heel jaar gezien (met natte en droge perioden) de belangrijkste bron van $\mathrm{N}_{2} \mathrm{O}$ is in Nederlandse landbouwgronden.

\subsubsection{Omgevingsfactoren}

Uit de vorige paragrafen blijkt dat er een groot aantal bodemprocessen is waarbij $\mathrm{N}_{2} \mathrm{O}$ wordt gevormd. Veel factoren spelen daardoor een rol bij de $\mathrm{N}_{2} \mathrm{O}$-emissie uit landbouwgronden:

- Factoren die een effect hebben op de gehalten aan minerale stikstof (nitraat en ammonium) in de bodem, zoals bemesting en mineralisatie van organische stof. Hoe meer minerale stikstof aanwezig is in de bodem, hoe hoger het risico op $\mathrm{N}_{2} \mathrm{O}$-emissie.

- Factoren die een effect hebben op de hoeveelheid afbreekbare organische stof in de bodem, zoals de aanwezigheid van organische stof in een meststof (bv. mest) en gewasrest en het gehalte aan 
organische stof van de bodem. Hoe meer afbreekbare organische stof in de bodem aanwezig is, hoe hoger het risico op $\mathrm{N}_{2} \mathrm{O}$-emissie.

- Factoren die een effect hebben op het zuurstofgehalte van de bodem, zoals neerslag, grondwaterstand, zuurstofconsumptie tijdens afbraak van organische stof en bodemverdichting. Lachgasemissie treedt op bij lage zuurstofgehalten, maar onder volledig zuurstofloze omstandigheden wordt $\mathrm{N}_{2} \mathrm{O}$ gereduceerd tot het onschadelijk stikstofgas $\left(\mathrm{N}_{2}\right)$.

- Overige factoren die een effect hebben op activiteit van bacteriën, zoals de temperatuur, $\mathrm{pH}$, zoutsterkte en de aanwezigheid van toxische verbindingen (zware metalen en bepaalde organische verbindingen). Het effect van deze factoren is lastig te voorspellen, omdat ze enerzijds resulteren in een lagere biologische activiteit, maar anderzijds kan de lachgasproductie wel toenemen. Het is bijvoorbeeld bekend bij denitrificatie dat de verhouding $\mathrm{N}_{2} \mathrm{O} / \mathrm{N}_{2}$ in het totale stikstofverlies door denitrificatie toeneemt als de temperatuur lager wordt (Firestone, 1982). Ook onder zure omstandigheden wordt er relatief veel $\mathrm{N}_{2} \mathrm{O}$ gevormd ten opzichte van $\mathrm{N}$.

Organische stof kan via verschillende mechanismen een effect hebben op $\mathrm{N}_{2} \mathrm{O}$-emissie:

1. Afbreekbare organische stof is de energiebron voor denitrificerende bacteriën.

2. Bij afbraak van organische stof wordt zuurstof geconsumeerd en dit kan leiden tot zuurstofloze omstandigheden in de bodem met een verhoogde denitrificatieactiviteit tot gevolg.

3. Organische stof is belangrijk voor de bodemstructuur. Structuurbederf door een laag gehalte aan organische stof kan leiden tot een lager zuurstofgehalte in de bodem. Dit kan zowel leiden tot een hogere lachgasemissie als lagere lachgasemissie (onder zuurstofloze omstandigheden wordt $\mathrm{N}_{2} \mathrm{O}$ gereduceerd naar $\mathrm{N}_{2}$ ). Waarschijnlijk speelt de grondsoort hierbij een rol; in kleigronden is de kans op zuurstofloze omstandigheden waarbij $\mathrm{N}_{2} \mathrm{O}$ wordt gereduceerd tot $\mathrm{N}_{2}$ groter dan in zandgrond.

4. In organische stof kan minerale stikstof worden vastgelegd (immobilisatie) en dat kan leiden tot minder $\mathrm{N}_{2} \mathrm{O}$-emissie.

\subsection{Effect organische stof op lachgasemissie}

\subsubsection{Organische meststoffen}

Runder- en varkensdrijfmesten bevatten gemakkelijk afbreekbare organische verbindingen, zoals vluchtige vetzuren, suikers en proteïnen (Cooper and Cornforth, 1978; Morvan et al., 2006). $\mathrm{Na}$ toediening aan de bodem worden deze verbindingen snel afgebroken (Kirchmann and Lundvall, 1993). De vluchtige vetzuren in mesten zijn een energiebron voor denitrificerende bacteriën (Paul and Beauchamp, 1989b; Dendooven et al., 1998). De toename van $\mathrm{N}_{2} \mathrm{O}$-emissie gedurende de eerste dagen na toediening van dierlijke mest aan een bodem wordt waarschijnlijk veroorzaakt doordat gemakkelijk afbreekbare organische verbindingen in mest leiden tot denitrificatie van reeds in de bodem aanwezig nitraat (Stevens and Laughlin, 2001).

De soort mest, het stikstofgehalte en de mate waarin organische stof is afgebroken gedurende opslag, compostering en/of vergisting hebben een effect op $\mathrm{N}_{2} \mathrm{O}$-emissie (Bertora et al., 2008). In een studie onder gecontroleerde omstandigheden van Bertora et al. (2008) nam de $\mathrm{N}_{2} \mathrm{O}$-emissie toe in de volgorde onbehandelde varkensdrijfmest (emissiefactor 4,8\%), de dunne fractie van gescheiden mest $(2,6 \%)$, het digestaat van de dunne fractie $(1,8 \%)$, de vaste fractie $(1,0 \%)$ en ureum-kunstmest $(0,9 \%)$. Deze resultaten geven aan dat zowel de hoeveelheid stikstof als afbreekbare organische stof een rol spelen. Het vergisten van mest leidt tot afbraak van gemakkelijke hoeveelheid afbreekbare organische stof. Uit deze studie blijkt dat het toedienen van digestaat leidt tot een lagere $\mathrm{N}_{2} \mathrm{O}$-emissie dan niet-vergiste mest; dit is waarschijnlijk een effect van de lagere afbreekbaarheid van organische stof in digestaat.

In Figuur 19 wordt het effect weergegeven van toediening van een nitraathoudende kunstmest, het gemakkelijk afbreekbare glucose (koolstofbron zonder stikstof) en runderdrijfmest op $\mathrm{N}_{2} \mathrm{O}$-emissie. De $\mathrm{N}_{2} \mathrm{O}$-emissie was hoger bij glucose dan bij nitraatkunstmest, hetgeen aangeeft dat de aanwezigheid van gemakkelijk afbreekbare organische stof in deze grond een limiterende factor was voor $\mathrm{N}_{2} \mathrm{O}$ emissie. De $\mathrm{N}_{2} \mathrm{O}$-emissie na toediening van dunne rundermest was het hoogst in deze proef. De 
aanwezigheid van een combinatie van minerale stikstof en organische stof in de mest zal hierbij waarschijnlijk een belangrijke rol spelen, maar $\mathrm{N}_{2} \mathrm{O}$-productie door nitrificatie speelt mogelijk ook een rol.

In onderzoek van Velthof and Mosquera (2011) leidde toediening van dierlijke mest aan bouwland tot een hogere $\mathrm{N}_{2} \mathrm{O}$-emissie dan toediening van een nitraathoudende kunstmest, terwijl op grasland de toediening van nitraathoudende kunstmest tot een hogere emissie leidde dan mest. Dit kan verklaard worden door het hogere gehalte aan beschikbare organische stof en daardoor hogere denitrificatiecapaciteit in grasland dan in bouwland (Tabel 8). Het toedienen van organische stof met mest heeft daardoor op bouwland een groter effect op denitrificatie dan op grasland. Daarnaast neemt grasland stikstof snel op, zodat de periode met een verhoogd minerale stikstofgehalte na bemesting op grasland veel korter is dan op bouwland.

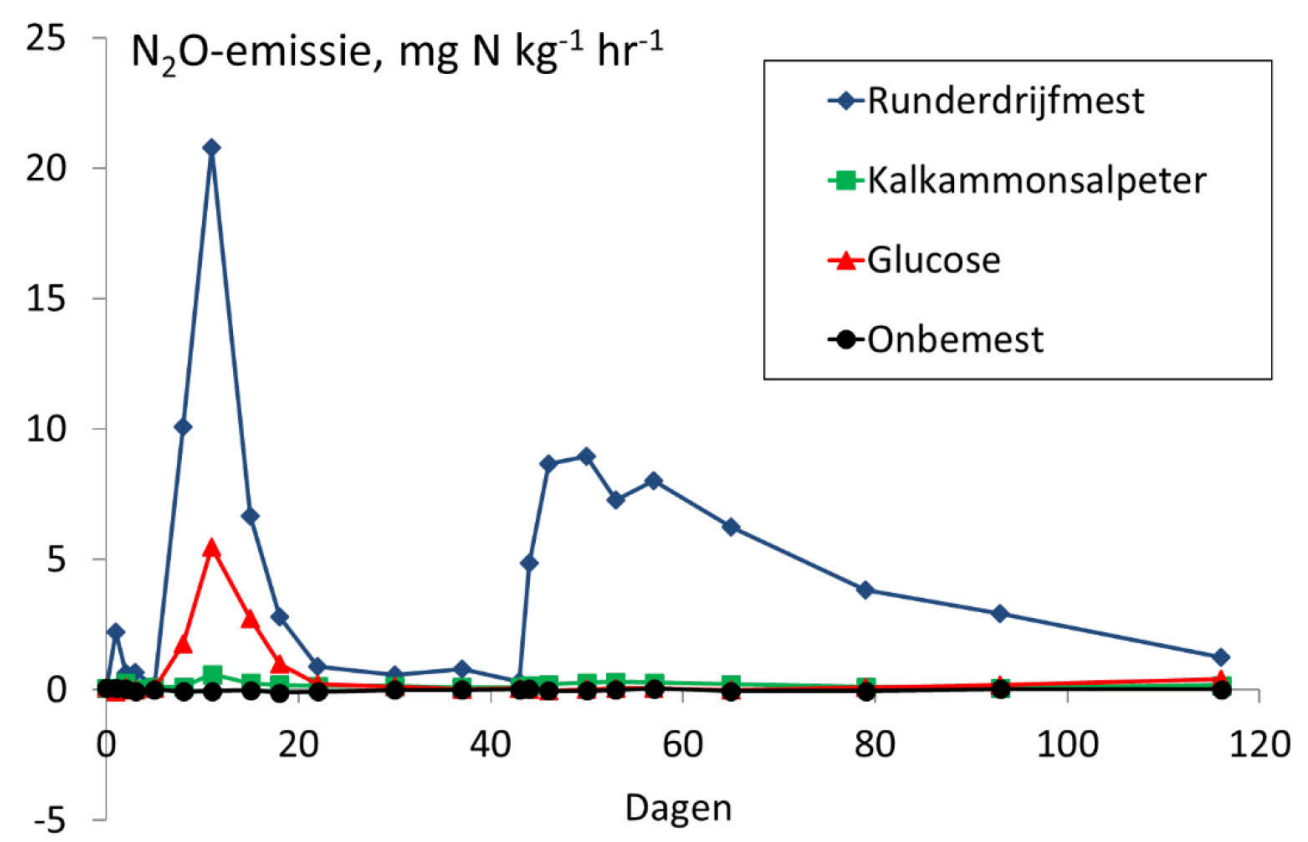

Figuur $19 \mathrm{~N}_{2} \mathrm{O}$-emissie uit onbemeste zandgrond en zandgrond na toediening van runderdrijfmest, kunstmest (kalkammonsalpeter) en glucose. Na 42 dagen is er $10 \mathrm{~mm}$ water toegediend om denitrificatie te stimuleren. Resultaten incubatieproef (Velthof, niet gepubliceerd).

Tabel $8 \quad$ Potentiële denitrificatie ${ }^{9}$ ( $\mathrm{mg} \mathrm{N}$ per $\mathrm{kg}$ droge grond per dag) in grasland en bouwland (maisland) in verschillende grondsoorten in Nederland (Munch en Velthof, 2007).

\begin{tabular}{|c|c|c|c|c|c|c|}
\hline \multirow[t]{2}{*}{ Bodemlaag } & \multicolumn{4}{|l|}{ Grasland } & \multicolumn{2}{|l|}{ Bouwland } \\
\hline & Veen $(n=3)$ & Klei $(n=3)$ & Löss $(n=2)$ & Zand $(n=3)$ & Löss $(n=2)$ & Zand $(n=3)$ \\
\hline $0-20 \mathrm{~cm}$ & 267 & 151 & 65 & 26 & 20 & 11 \\
\hline $40-60 \mathrm{~cm}$ & 116 & 5 & 1 & 0,1 & 1 & 0,1 \\
\hline $60-80 \mathrm{~cm}$ & 61 & 0,9 & 0,3 & 0,5 & 0,3 & 0 \\
\hline
\end{tabular}

In een meta-analyse (mondiaal niveau) werd het effect van gebruik van dierlijke mest op $\mathrm{N}_{2} \mathrm{O}$-emissie ten opzichte van kunstmest gekwantificeerd (Zhou et al., 2017). Lachgasemissie uit dierlijke mest was gemiddeld 32,7\% hoger dan uit kunstmest. De onderzoekers berekenden het gemiddelde effect op mondiaal niveau van het vervangen van kunstmest door dierlijke mest op bouwland op koolstofopslag

9 Incubatie onder zuurstofloze omstandigheden bij $20^{\circ} \mathrm{C}$ in een met nitraat aangerijkte grond met behulp van acetyleeninhibitietechniek. Meting van $\mathrm{N}_{2} \mathrm{O}$-toename met foto-akoestische gasmonitor na 1, 2 en 3 dagen. De gemiddelde potentiële denitrificatiesnelheid is de toename in $\mathrm{N}_{2} \mathrm{O}$-concentratie in 3 dagen. Verschillen in potentiële denitrificatie tussen gronden duiden op verschillen in afbreekbaarheid van organische stof. 
(-1140 kg CO 2 -equivalenten per ha per jaar) en $\mathrm{N}_{2} \mathrm{O}$-emissie ( $+419 \mathrm{~kg} \mathrm{CO}$-equivalenten per ha per jaar). Het effect van koolstofopslag op de reductie van $\mathrm{CO}_{2}$-emissie werd dus met $36,7 \%$ verlaagd door de toegenomen emissie van lachgas.

Ook toediening van gft-compost kan leiden tot een toename van de potentiële denitrificatie (Odlare and Pell, 2009). Dit geeft aan dat de organische stof in compost als energiebron gebruikt kan worden door denitrificerende bacteriën. In een studie in de USA (Zhu-Barker et al., 2015) leidde toediening van groencompost tot een hoger $\mathrm{N}_{2} \mathrm{O}$-emissie op een zandgrond, maar niet op een kleigrond. Op de zandgrond was de $\mathrm{N}_{2} \mathrm{O}$-emissie een factor 1,4 tot 2,9 hoger bij de combinatie kunstmest (zowel ammoniumsulfaat en ammoniumnitraat) en groencompost dan bij alleen kunstmest. Nitrificatie was de belangrijkste bron van $\mathrm{N}_{2} \mathrm{O}$-emissie in dit onderzoek; de hogere $\mathrm{N}_{2} \mathrm{O}$-emissie werd toegeschreven aan een verhoogde zuurstofconsumptie door afbraak van organische stof en een verhoging van de $\mathrm{pH}$ door toediening van de compost (de compost had een $\mathrm{pH}-\mathrm{KCl}$ van 8,1 ). De afwezigheid van effecten in de kleigrond werd toegeschreven aan buffering van $\mathrm{pH}$ en remming van nitrificatie in de kleigrond. In een studie van Nicholson et al. (2017) in Engeland op zowel grasland als bouwland was de $\mathrm{N}_{2} \mathrm{O}$-emissie na toediening van groencompost veel lager dan die van digestaat van vergiste voedselafval, stalmest en drijfmest. De lage $\mathrm{N}_{2} \mathrm{O}$-emissie bij groencompost wordt waarschijnlijk veroorzaakt door het lage aandeel minerale $\mathrm{N}$ in de totale hoeveelheid en een lagere afbreekbaarheid van de organische stof.

\subsubsection{Gewasresten}

Gewasresten bevatten gemakkelijk afbreekbare organische verbindingen (Paul and Beauchamp, 1989). In een meta-analyse van een groot aantal studies komt duidelijk naar voren dat de $\mathrm{N}_{2} \mathrm{O}$ emissie uit gewasresten hoger wordt naarmate de $\mathrm{C} / \mathrm{N}$-ratio in gewasresten lager wordt ((Chen et al., 2013). De emissie van stroachtige gewasresten van bijvoorbeeld granen is meestal gering en veel lager dan die van stikstofrijke gewasresten van bijvoorbeeld groenten (Baggs et al., 2000; Baggs et al., 2003). De $\mathrm{N}_{2} \mathrm{O}$-emissie door toediening van gewasresten is hoger indien er nitraat in de bodem aanwezig is; dit geeft aan dat de organische stof in gewasresten kan leiden tot een verhoogde denitrificatie van reeds in de bodem aanwezig nitraat (Velthof et al., 2002).

Een meta-analyse (mondiaal niveau) van Xia et al. (2018) laat zien dat het achterlaten van stro gemiddeld leidt tot een significante toename van het gehalte aan organische stof in de bodem (toename met $14,9 \%)$, gewasopbrengst $(5,1 \%)$ en stikstofopname door het gewas $(10,9 \%)$ ten opzichte van afvoeren van stro. De lachgasemissie uit bouwland neemt toe met $21,5 \%$, voornamelijk door het stimuleren van nitrificatie en denitrificatie. Het positieve effect van stro op $\mathrm{N}_{2} \mathrm{O}$-emissie is groter op zandgrond dan op kleigrond. Mogelijk dat de reductie van $\mathrm{N}_{2} \mathrm{O}$ naar $\mathrm{N}_{2}$ tijdens denitrificatie in kleigronden sneller verloopt dan in zandgronden, omdat het zuurstofgehalte in kleigronden lager is. De extra zuurstofconsumptie door afbraak van stro zal dit verschil tussen klei- en zandgronden versterken.

\subsubsection{Landbouwgronden}

In de literatuur zijn verschillende studies gepubliceerd waarin een positieve relatie is gevonden tussen het gehalte aan organische stof en denitrificatie. Veelal is de relatie tussen het gehalte aan wateroplosbare organische stof (en andere indicatoren voor afbreekbare organische stof) en denitrificatie sterker dan tussen het totaal gehalte aan organische stof en denitrificatie (Burford and Bremner, 1975; Bijay et al., 1988). Dit geeft aan dat niet alle organische stof in de bodem beschikbaar is als energiebron voor denitrificerende bacteriën en dan niet alle organische stof leidt tot een toename van lachgasemissie.

Metingen in monsters van zand- en lössgronden in Nederland laten een significante relatie zien tussen de potentiële denitrificatie en het gehalte aan oplosbaar $\mathrm{C}^{10}$ (Figuur 20). Er was ook een significante relatie met het gehalte aan totaal $\mathrm{C}$, maar het verband was minder sterk dan die met oplosbaar $\mathrm{C}$. Uit deze figuur blijkt ook dat de relatie veel duidelijker is voor grasland dan voor bouwland en dat zowel het gehalte aan oplosbaar $\mathrm{C}$ als de potentiële denitrificatie gemiddeld hoger is voor grasland dan voor

\footnotetext{
${ }^{10}$ Drogen van grond bij $40^{\circ} \mathrm{C}$, extractie met $0,01 \mathrm{M} \mathrm{CaCl}_{2}$-bepaling organische $\mathrm{C}$ in extract (Houba et al., 2000).
} 
bouwland. Het hogere organischestofgehalte in grasland wordt veroorzaakt door een combinatie van factoren. Op grasland vindt vrijwel geen grondbewerking plaats (alleen bij graslandvernieuwing), waardoor er geen grondbewerking-geïnduceerde organische stofafbraak optreedt. Grasland heeft bovendien een groot, uitgebreid wortelstelsel en de afbraak van wortels en de uitscheiding van organische verbindingen door wortels (exudaten) is een grote bron van gemakkelijke afbreekbare organische stof in de bodems onder grasland. In Nederland wordt bovendien veel dierlijke mest toegediend aan grasland of tijdens beweiding uitgescheiden. De gebruiksnormen voor dierlijke mest en fosfaat laten een hoger gebruik van dierlijke mest op grasland dan op bouwland toe.

In een meta-analyse zijn de effecten van conserveringslandbouw met beperkte grondbewerking op $\mathrm{N}_{2} \mathrm{O}$-emissie onderzocht, waarbij publicaties uit landbouwsystemen over de gehele wereld werden meegenomen (Mei et al., 2018). De $\mathrm{N}_{2} \mathrm{O}$-emissie was gemiddeld ongeveer $18 \%$ hoger in conserveringslandbouw dan in reguliere landbouw. Deze toename werd toegeschreven aan effecten op het zuurstofgehalte in de bodem en de beschikbaarheid van organische stof voor denitrificerende bacteriën bij beperkte grondbewerking. De toename van $\mathrm{N}_{2} \mathrm{O}$-emissie door conserveringslandbouw was hoger naarmate het gehalte aan organische stof in de bodem hoger was. Ook in andere studies werd geconstateerd dat beperkte grondbewerking kan leiden tot een toename van $\mathrm{N}_{2} \mathrm{O}$-emissie en dat dit effect mee moet worden genomen indien koolstofopslag in de bodem als maatregel wordt ingezet (Antle and Ogle, 2012; Six et al., 2004).

potentiële denitrificatie, $\mathrm{mg} \mathrm{N} \mathrm{kg}^{-1} \mathrm{dag}^{-1}$

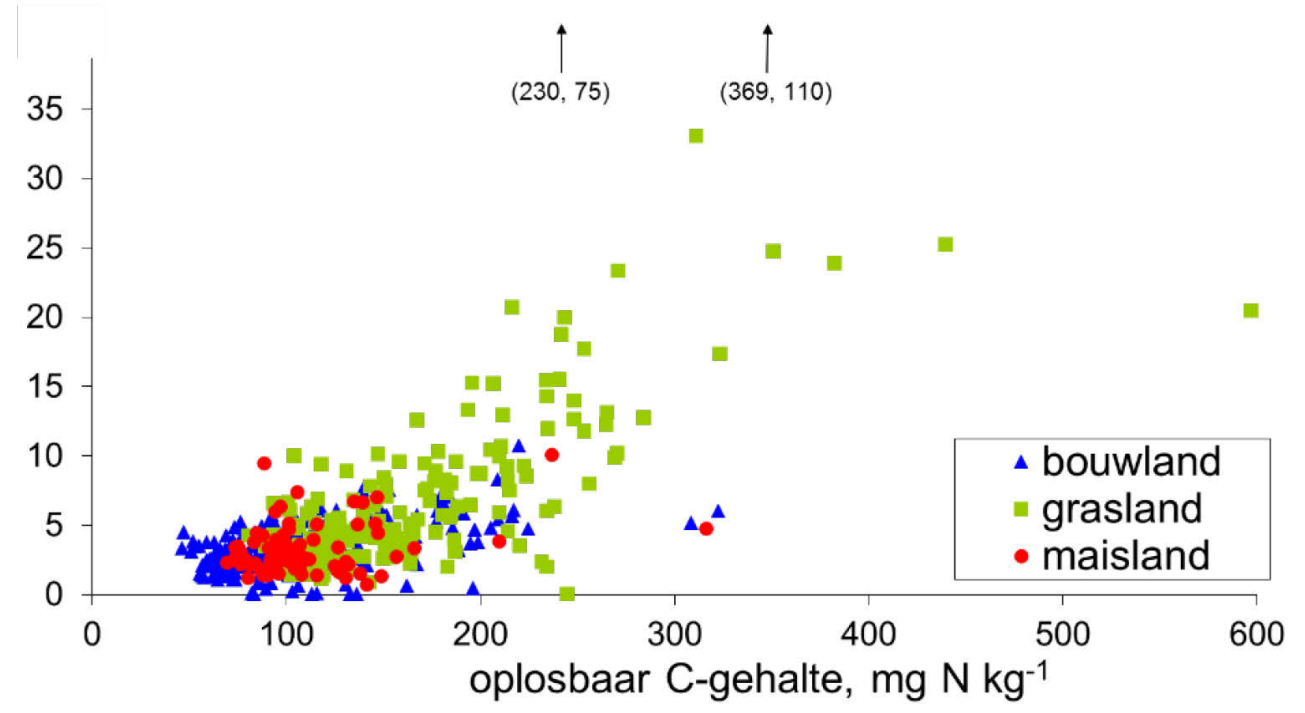

Figuur 20 Relatie tussen gehalte aan oplosbaar organische $C\left(0,01 \mathrm{M} \mathrm{CaCl}_{2}\right)$ en potentiële denitrificatie in zandgrond (Velthof, 2003).

Experimenteel onderzoek in China laat duidelijk zien dat $\mathrm{N}_{2} \mathrm{O}$-emissie toeneemt naarmate het gehalte aan organische stof toeneemt (Gu et al., 2017). De verschillen in organische stof waren gecreëerd door verschillende behandelingen met kunstmest, gewasresten en verschillende giften aan dierlijke mest. Op basis van deze metingen en berekeningen over het verloop in de toekomst, concludeerden de auteurs dat in de objecten met de sterkste toename van organische stof in de bodem (de gewasrest- en mestobjecten), de totale broeikasgasemissie daalt gedurende de eerste 7-12 jaren van extra toevoer van organische stof doordat er koolstof wordt opgeslagen, en daarna stijgt door de toenemende $\mathrm{N}_{2} \mathrm{O}$-emissie (Figuur 22). Na verloop van tijd is het effect op $\mathrm{N}_{2} \mathrm{O}$-emissie hoger dan het effect op koolstofopslag.

Modelberekeningen met het model Daycent door Lugato et al. (2018) laten een vergelijkbaar beeld zien als het experiment van Gu et al. (2017). Gemiddeld dalen de broeikasemissies uit bouwland in de Europese Unie gedurende 20-30 jaar van beperkte grondbewerking met extra aanvoer van gewasresten; het effect van koolstofopslag is in deze periode groter dan het effect op $\mathrm{N}_{2} \mathrm{O}$-emissie. 
Daarna is de $\mathrm{N}_{2} \mathrm{O}$-emissie uitgedrukt in $\mathrm{CO}_{2}$-equivalenten groter dan de koolstofopslag. Berekeningen met het model Daycent laten ook zien dat ook op grasland een toename in $\mathrm{N}_{2} \mathrm{O}$-emissie door bemesting het effect van koolstofopslag sterk kan reduceren en soms volledig teniet kan doen (Conant et al., 2005).

In een incubatiestudie met bodemmonsters van veeljarige experimenten in Duitsland was de $\mathrm{N}_{2} \mathrm{O}$ emissie significant hoger in bodems met een hoger gehalte aan organische stof in de bodem, ontstaan door veeljarige toediening van stalmest (Jager et al., 2011). Het effect van stikstofbemesting op $\mathrm{N}_{2} \mathrm{O}-$ emissie was echter veel groter dan het effect van het gehalte aan organische stof in de bodem.

Simulaties met het biogeochemisch model DNDC laten zien dat een beperkte grondbewerking, extra toediening van gewasresten en toediening van stalmest leidden tot een toename van zowel het gehalte aan organische stof als $\mathrm{N}_{2} \mathrm{O}$-emissie ( $\mathrm{Li}$ et al., 2005). Er was geen effect op de methaanemissie. Over een periode van 20 jaar was het effect van een toename van de $\mathrm{N}_{2} \mathrm{O}$-emissie op de totale broeikasgasemissie groot: de $\mathrm{N}_{2} \mathrm{O}$-emissie, uitgedrukt in $\mathrm{CO}_{2}$-equivalenten, bedroeg $75-310 \%$ van de $\mathrm{CO}_{2}$ die in de bodem was opgeslagen.

Berekeningen van Bos et al. (2017) met het model NutMatch voor een akkerbouwrotatie in Nederland lieten zien dat het gebruik van gewasresten, rundermest of compost leidde tot een substantiële koolstofvastlegging (200-450 kg C per ha per jaar) op het niveau van gewasrotatie. Het effect van varkensmest en vanggewassen op koolstofvastlegging was veel kleiner (20-50 kg C per ha per jaar). De emissie van $\mathrm{N}_{2} \mathrm{O}$ nam ook toe. De auteurs berekenden dat de maximaal acceptabele $\mathrm{N}_{2} \mathrm{O}$-emissie $0,75 \mathrm{~kg} \mathrm{~N} 2 \mathrm{O}-\mathrm{N}$ per $100 \mathrm{~kg}$ extra bodemorganische $\mathrm{C}$ bedraagt. Dit was in deze studie het omslagpunt waarbij het effect van $\mathrm{N}_{2} \mathrm{O}$-emissie groter is dan van koolstofopslag. Alleen bij gebruik van compost was de $\mathrm{N}_{2} \mathrm{O}$-emissie lager dan dit omslagpunt $\left(0,61-0,73 \mathrm{~kg} \mathrm{~N} \mathrm{~N}_{2} \mathrm{O}-\mathrm{N}\right.$ per $100 \mathrm{~kg}$ extra organische $\mathrm{C}$ in de bodem). 

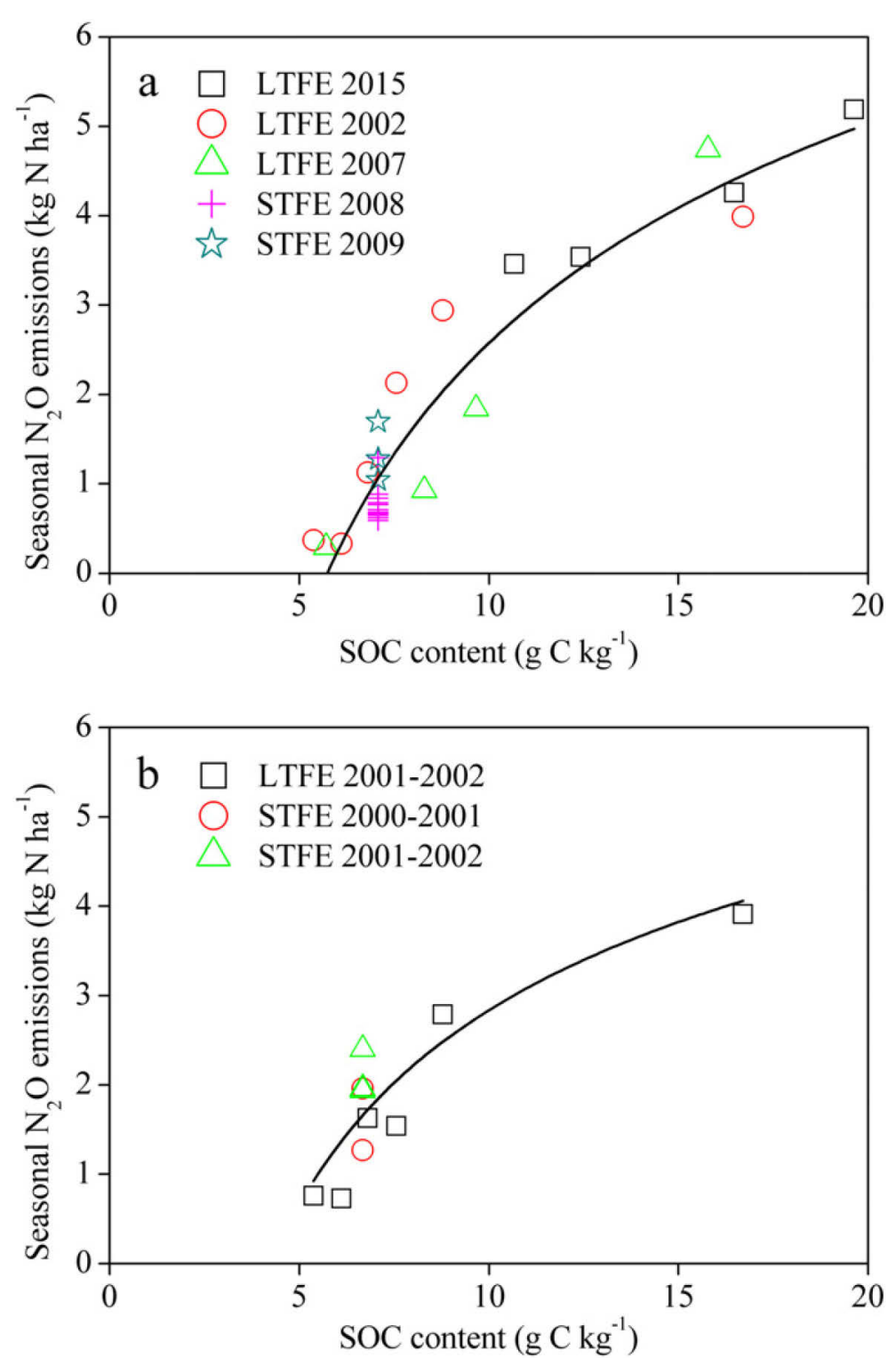

Figuur 21 Relatie tussen gehalten aan organische $\mathrm{C}$ in de $0-20 \mathrm{~cm}$-bodemlaag en $\mathrm{N}_{2} \mathrm{O}$-emissie voor (a) zomermais en (b) wintertarwe in experimenten in China met verschillende hoeveelheden organische stof (Guanzhong Plain) (Gu et al., 2017).

In een recente meta-analyse (mondiaal niveau) van Guenet et al. (2021) naar het effect van koolstofopslag in landbouwgronden werd geconcludeerd dat koolstofopslag vaak leidt tot een hogere $\mathrm{N}_{2} \mathrm{O}$-emissie. In de berekening van de netto broeikasgasemissie moet hier rekening mee worden gehouden. De meeste maatregelen om koolstof op te slaan, hebben netto een positief effect op reductie van broeikasgasemissies, behalve beperkte grondbewerking. Bij beperkte grondbewerking is volgens deze studie gemiddeld genomen de toename van $\mathrm{N}_{2} \mathrm{O}$-emissie groter dan de koolstofopslag.

$\mathrm{Bij}$ de andere koolstofmaatregelen is er nog steeds sprake van reductie van de netto broeikasgasemissies en sommige maatregelen (zoals biochar) leiden tot koolstofvastlegging én reductie van lachgasemissie (Figuur 23). 

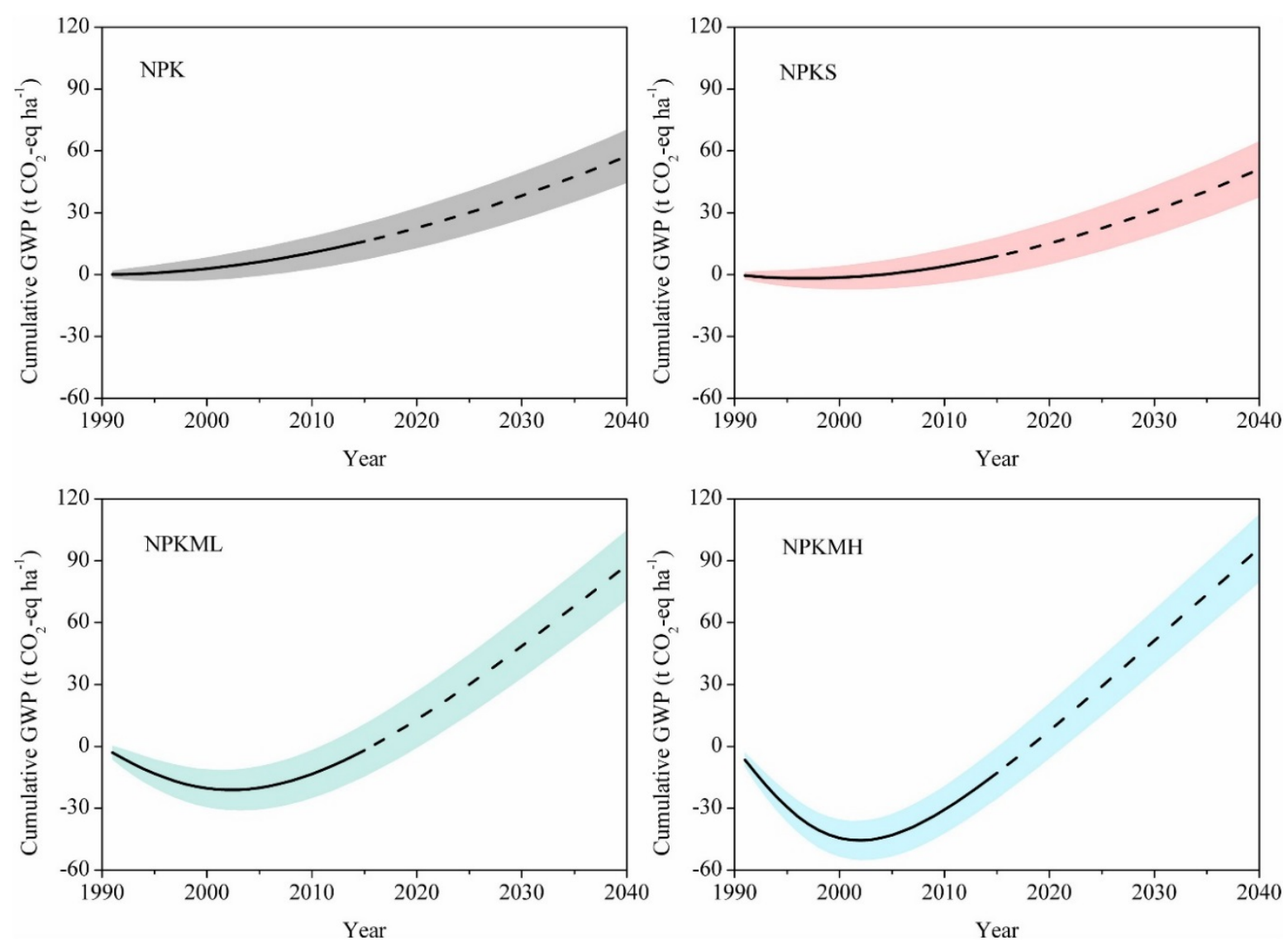

Figuur 22 Netto broeikasgasemissie (in $\mathrm{CO}_{2}$-equivalenten) bij vier typen beheer in China met verschillende hoeveelheden organische stof (Guanzhong Plain). NPK is alleen kunstmest; NPKS is kunstmest en gewasresten; NPKML kunstmest met lage mestgift en NPKMH kunstmest met hoge mestgift (Gu et al., 2017). De doorgetrokken lijnen zijn gebaseerd op metingen en de stippellijnen geven een voorspelling weer. De gekleurde band geeft het 95\%-betrouwbaarheidsinterval weer.

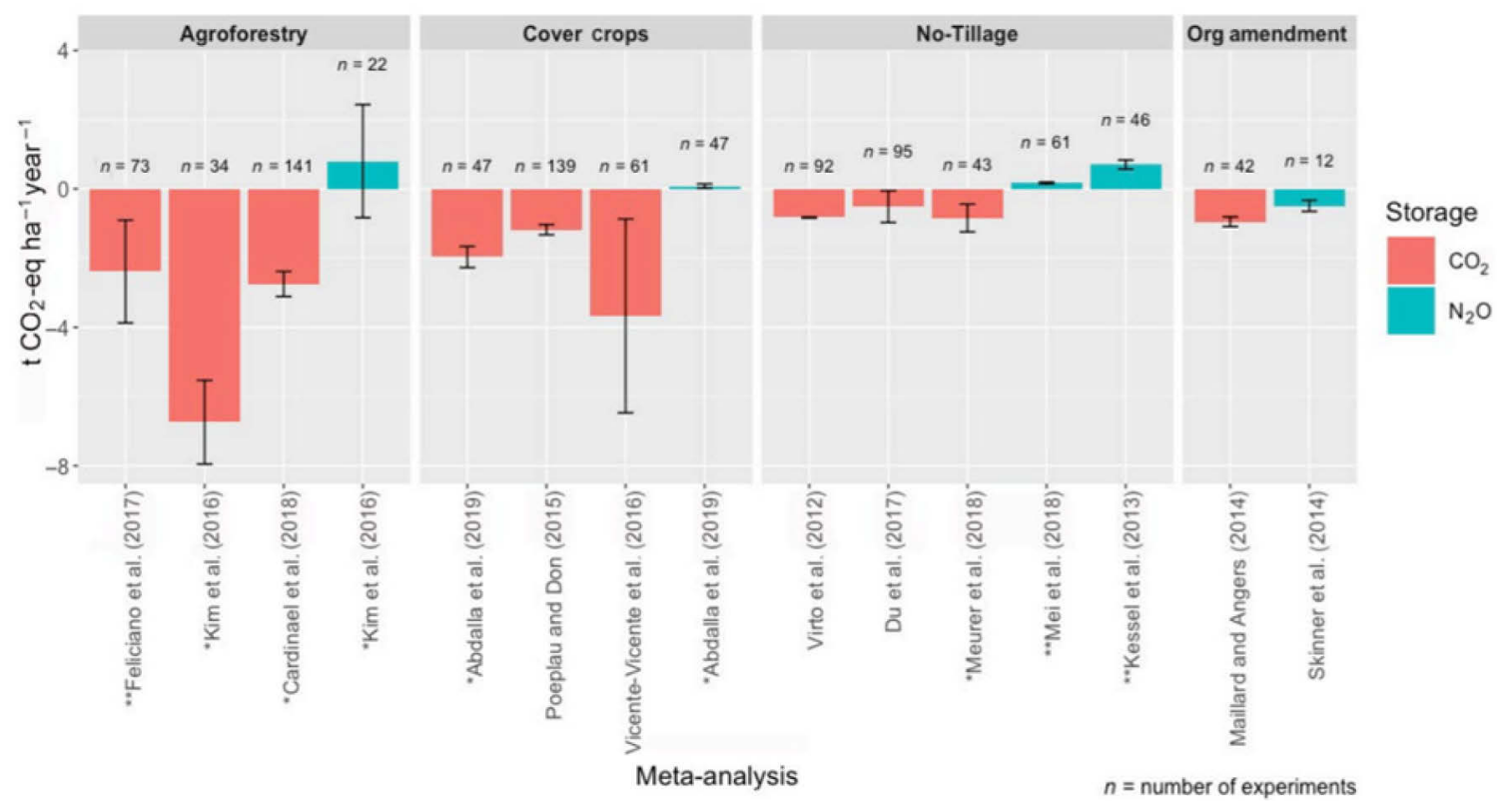

Figuur 23 Schatting van koolstofopslag (in rood) en $\mathrm{N}_{2} \mathrm{O}$-emissie (in groen) in $\mathrm{CO}_{2}$-equivalenten bij verschillende maatregelen om koolstof op te slaan. Negatieve waarden betekenen dat netto broeikasgasemissie afneemt en positieve waarden betekenen dat netto broeikasgasemissie toeneemt. In alle genoemde studies is de koolstofmaatregel vergeleken met een controle met regulier beheer Guenet et al. (2021). 


\subsection{Organische stof en nitraatuitspoeling}

Uitspoeling van nitraat uit de bodem vindt plaats in perioden met een neerslagoverschot in combinatie met ophoping van nitraat in de bodem. Als het nitraat dieper in de bodem zit dan de meeste plantenwortels (vaak $>60 \mathrm{~cm}$ ), dan is het nitraat feitelijk niet meer beschikbaar voor opname door de wortels en is het nitraat 'uitgespoeld'. In Nederland vindt uitspoeling vooral plaats in het najaar en de winter, omdat er dan een neerslagoverschot is en het bouwland onbegroeid is dan wel dat het aanwezige gewas weinig $\mathrm{N}$ uit de bodem opneemt vanwege te lage temperatuur en te weinig zon. $\mathrm{Er}$ zijn veel factoren die de grootte van de nitraatuitspoeling bepalen en er zijn ook veel factoren die de nitraatuitspoeling kunnen beperken. Belangrijke factoren zijn landgebruik, bemesting, grondsoort, grondwaterstand en klimaat. Grondsoort en grondwaterstand hebben in Nederland een grote invloed op de nitraatconcentratie in het water dat uit de wortelzone spoelt.

In een review van Edmeades (2003) werden de resultaten van veertien veeljarige veldproeven (20-120 jaar) naar de effecten van kunstmest en organische meststoffen (stalmest, dunne mest en groencompost) op gewasopbrengst en bodemeigenschappen geëvalueerd. Veeljarige toediening van mest leidt tot een hoger gehalte aan organische stof, een hogere biodiversiteit en een hoger gehalte aan fosfaat, calcium, kalium en magnesium in de bovengrond. Het nitraatgehalte in de ondergrond neemt ook toe. Uit de studie kwam naar voren dat, in vergelijking met kunstmest, een sterkere accumulatie van stikstof en fosfaat in de bodem kan optreden bij veeljarig gebruik van organische meststoffen. Er werd geconcludeerd dat het veeljarige gebruik van organische meststoffen het risico op uit- en afspoeling van nitraat naar grond- en oppervlaktewater verhoogt.

In een review van Diacono and Montemurro (2010) werd geconcludeerd dat het veeljarige gebruik van gecomposteerde organische meststoffen leidt tot een toename van het organische-stikstofgehalte in landbouwgronden. Deze organische stikstof kan na mineralisatie beschikbaar worden voor het gewas. De effecten op nitraatuitspoeling waren wisselend; vaak was er geen effect, maar er zijn ook studies waarin de nitraatuitspoeling afnam en studies waarin de nitraatuitspoeling toenam. In een studie in Frankrijk werd het effect van langdurig gebruik van compost op de uitspoeling van nutriënten, inclusief stikstof, onderzocht (Cambier et al., 2014). Metingen van de nitraatconcentratie op $1 \mathrm{~m}$ diepte lieten zien dat gemiddeld de nitraatconcentratie het hoogst was bij gecomposteerd zuiveringsslib, gft-compost en stalmest, gevolg door gecomposteerd stedelijk afval en het gebruik van alleen kunstmest.

In een meerjarige studie in Oostenrijk leidde het gebruik van gft-compost tot een lage en vergelijkbare nitraatuitspoeling als bij het gebruik van kunstmest (Erhart et al., 2007). In een zesjarige studie van Basso and Ritchie (2005) in de Verenigde staten met een rotatie van mais en luzerne en behandelingen met verschillende organische meststoffen, werd de hoogste nitraatuitspoeling gevonden bij gebruik van stalmest, gevolgd door composteerde mest, kunstmest en de onbemeste controle. In een vierjarige studie van Nevens and Reheul (2003) in Vlaanderen met gftcompost en dunne rundermest bij mais was het organischestofgehalte in behandelingen met compost na vier jaar hoger dan in behandelingen met dunne rundermest. Gft-compost leidde niet tot een toename van het risico op nitraatuitspoeling (uitgedrukt als minerale $\mathrm{N}$ in de bodem na de oogst in de herfst), mits de stikstofgift met kunstmest werd aangepast aan die van gft-compost. Gebruik van dunne rundermest leidde tot een hoger risico op nitraatuitspoeling dan gft-compost. Maeda et al. (2003) concludeerden op basis van een meerjarige studie in Japan dat gebruik van gecomposteerde varkensmest in plaats van kunstmest kan leiden tot minder nitraatuitspoeling gedurende de eerste jaren van gebruik. Bij herhaald gebruik van gecomposteerde varkensmest op langere termijn neemt de nitraatuitspoeling echter toe.

In een studie van Hansen et al. (2015) in Denemarken had het laten liggen of het verwijderen van tarwestro gedurende zeven jaar geen effect op de nitraatuitspoeling. Olsen et al. (2004) onderzochten de effecten van bouwplan, vanggewassen en de toediening van dierlijke mest op de uitspoeling van nitraat op drie locaties in Denemarken over een periode van vijf jaar. Ze vonden grote verschillen tussen gewasrotaties (aandeel granen en leguminosen), een fors lagere nitraatspoeling bij gebruik van een vanggewas, terwijl de toediening van dierlijke mest geen significant effect op de uitspoeling van nitraat gaf. Een meta-analyse (mondiaal niveau) van Xia et al. (2018) laat zien dat het achterlaten 
van stro gemiddeld leidt tot een significante afname van nitraatuitspoeling (met 9,8\%) en oppervlakkige afspoeling van stikstof (met $26,4 \%$ ).

Voor Nederland heeft Van der Wal et al. (2019) een studie uitgevoerd naar de relatie tussen bodemorganischestof en nitraatuitspoeling. Hiervoor hebben ze gebruikgemaakt van het landelijke meetnet effecten mestbeleid (LMM) voor bedrijven op zandgrond, aangezien het risico op nitraatuitspoeling hoger is voor zandgronden. Hierbij zijn gegevens over het organischestofgehalte en nitraatconcentraties in het grondwater aan elkaar gekoppeld voor 243 percelen. De nitraatconcentratie in het bovenste grondwater was gemiddeld veel hoger onder permanent bouwland dan onder grasland in rotatie met bouwland en onder permanent grasland. De resultaten laten zien dat een hoger bodemorganischestofgehalte over het algemeen correleert met een lagere nitraatconcentratie (Figuur 24). Wel is het mogelijk dat grondsoorteffecten hier nog doorheen spelen (bv. moerige gronden versus andere zandgronden).

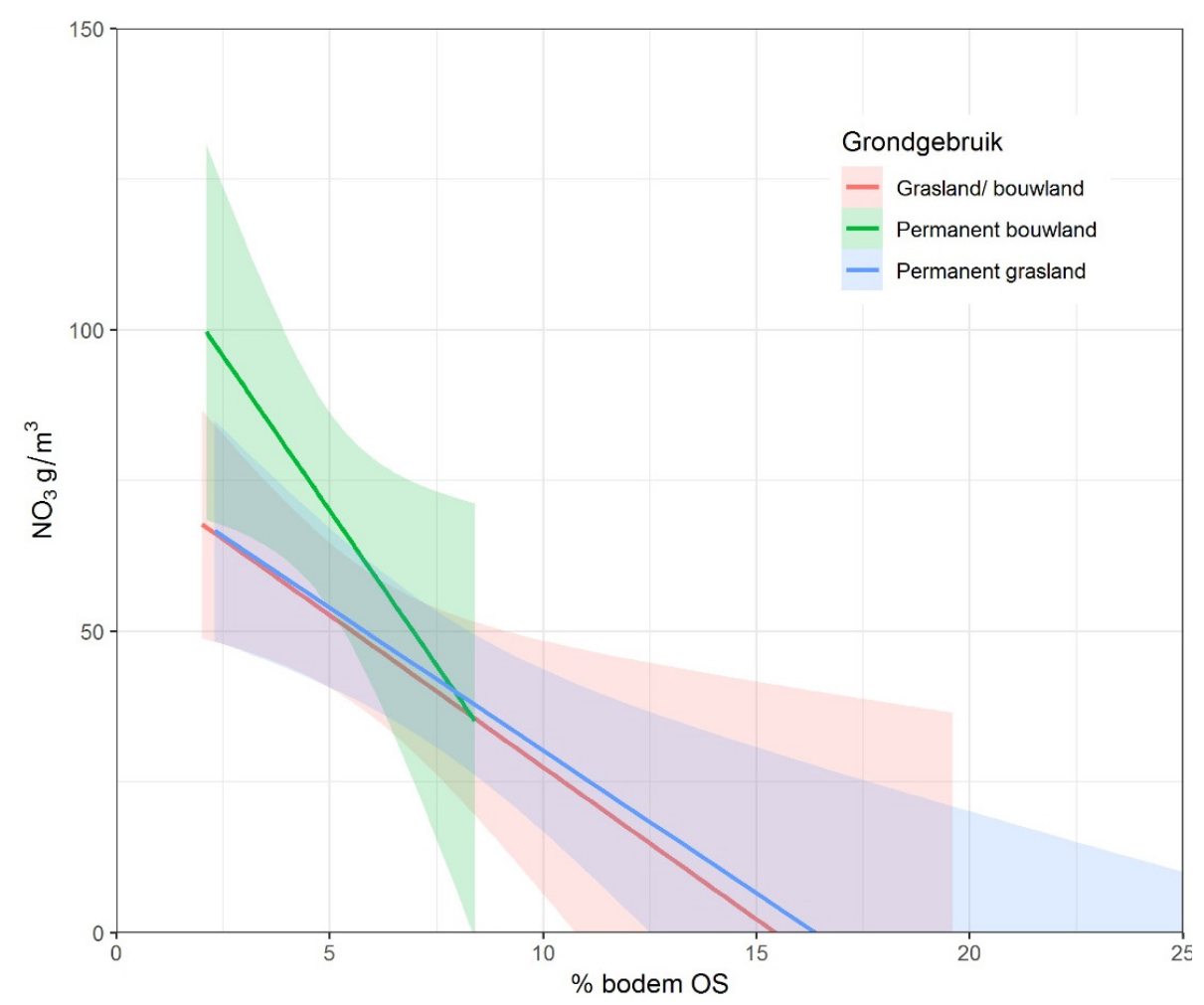

Figuur 24 Regressielijnen met 95\%-betrouwbaarheidsinterval tussen nitraatconcentratie in bovenste grondwater en het organischestofgehalte voor verschillend landgebruik (bron RIVM) ${ }^{11}$.

Concluderend komt uit de literatuur een wisselend beeld naar voren van het effect van het gebruik van organische meststoffen op nitraatuitspoeling ten opzichte van minerale meststoffen: soms een hogere uitspoeling, soms een lagere uitspoeling en soms geen effect. Belangrijke sturende factoren daarbij zijn de aard en samenstelling van de gebruikte organische meststoffen, de totale $\mathrm{N}$-gift via organische mest en kunstmest, het bouwplan (en de teelt van vanggewassen), grondsoort, het klimaat en de duur van de studie. De totale $\mathrm{N}$-gift en de mate waarin daarbij rekening wordt gehouden met de nawerking van de (eerder) toegediende $\mathrm{N}$ via de organische meststoffen is vooral belangrijk.

Ook speelt soms een rol dat organische meststoffen het organischestofgehalte van de bodem verhogen en daardoor ook de N-mineralisatie en potentiële denitrificatiecapaciteit. De wisselwerking tussen $\mathrm{N}$-gift, N-mineralisatie, N-opname door het hoofdgewas (en vanggewas), denitrificatie grondsoort en weersomstandigheden bepaalt uiteindelijk welk gedeelte van de $\mathrm{N}$-gift en van het $\mathrm{N}$ overschot door uitspoeling van nitraat verloren gaat. Voor Nederlandse condities lijkt een hoger organischestofgehalte te zorgen voor een lagere nitraatuitspoeling.

\footnotetext{
${ }^{11}$ https://www.rivm.nl/nieuws/relatie-tussen-bodemorganische-stof-en-nitraatuitspoeling
} 


\subsection{Synthese}

Uit de literatuurstudie komt naar voren dat toediening van organische stof meestal leidt tot een toename van $\mathrm{N}_{2} \mathrm{O}$-emissie. Twee mechanismen spelen hierbij een rol:

1. gemakkelijke afbreekbare organische stof is een energiebron voor denitrificerende bacteriën;

2. afbraak van organische stof leidt tot verhoogde zuurstofconsumptie en daardoor kan de $\mathrm{N}_{2} \mathrm{O}$ productie bij nitrificatie en denitrificatie toenemen.

De effecten van organische meststoffen en organische stof in de bodem zijn wisselend, maar veel studies laten zien dat de toename van $\mathrm{N}_{2} \mathrm{O}$-emissie door organische stof een forse reductie geeft van het totale effect in termen van netto broeikasgasemissies via koolstofvastlegging in landbouwgronden; sommige studies geven zelfs aan dat voor bepaalde maatregelen het effect van $\mathrm{N}_{2} \mathrm{O}$-emissie groter is dan van $\mathrm{CO}_{2}$-opname en koolstofopslag in de bodem. In dat geval heeft toevoer van organische stof aan landbouwgronden zelfs een negatief effect op de netto broeikasgasemissies. De recentste reviewstudie van Guenet et al. (2021) laat zien dat maatregelen om koolstof op te slaan een risico geven op extra lachgasemissie, maar dat de meeste netto een positief effect hebben op reductie van broeikasgasemissies, behalve niet-kerende grondbewerking. Het uiteindelijke effect op $\mathrm{N}_{2} \mathrm{O}$-emissies hangt ook sterk af van het huidige gewas- en bodembeheer, bijvoorbeeld als nu het gebruik van drijfmest de standaard is, dan leidt vervanging van drijfmest door een vaste mest of compost tot minder $\mathrm{N}_{2} \mathrm{O}$-emissie, terwijl vervanging van kunstmest door vaste mest mogelijk leidt tot meer $\mathrm{N}_{2} \mathrm{O}$ emissies.

Uit de literatuur komt een wisselend beeld naar voren van het effect van het gebruik van organische meststoffen op nitraatuitspoeling (en daarmee de indirecte lachgasemissie) ten opzichte van minerale meststoffen: soms een hogere uitspoeling, soms een lagere uitspoeling en soms geen effect. Een hoger organischestofgehalte van de bodem lijkt juist wel te leiden tot een lagere nitraatuitspoeling.

Nederlandse landbouwgronden hebben een hoog gehalte aan organische stof ten opzichte van veel andere landen door de hoge bemesting met mest en de hoge gewasopbrengsten. Het is niet bekend wat het effect is van extra toevoer van organische stof aan landbouwgronden in Nederland op $\mathrm{N}_{2} \mathrm{O}$ emissie. In het kader van het Slim Landgebruik-programma vinden nu wel veel $\mathrm{N}_{2} \mathrm{O}$-metingen plaats om hier meer zicht op te krijgen. In Tabel 9 wordt een indicatie gegeven van het verwachte effect van maatregelen om koolstofopslag in minerale landbouwgronden te verhogen op $\mathrm{N}_{2} \mathrm{O}$-emissie. Aangezien in het Klimaatakkoord wordt ingezet op koolstofopslag in landbouwgronden voor klimaatmitigatie is het belangrijk om inzicht te hebben wat het effect hiervan is op $\mathrm{N}_{2} \mathrm{O}$-emissie. 
Tabel 9 Effecten van maatregelen om koolstof vast te leggen in minerale landbouwgronden op de emissie van $\mathrm{N}_{2} \mathrm{O}$.

\begin{tabular}{|c|c|}
\hline Maatregel & Effect op $\mathrm{N}_{2} \mathrm{O}$-emissie \\
\hline Minder grondbewerking & $\begin{array}{l}\text { Indien minder grondbewerking leidt tot een slechtere structuur en } \\
\text { zuurstofvoorziening van bodems kan dit leiden tot een hogere } \mathrm{N}_{2} \mathrm{O} \text {-emissie uit } \\
\text { toegediende meststoffen. }\end{array}$ \\
\hline Niet scheuren van grasland & $\begin{array}{l}\text { Het minder vaak scheuren van grasland leidt tot een lager risico op } \mathrm{N}_{2} \mathrm{O} \text { - } \\
\text { emissie. Ook het risico op nitraatuitspoeling en de daaraan gerelateerde } \\
\text { indirecte } \mathrm{N}_{2} \mathrm{O} \text {-emissie neemt af. }\end{array}$ \\
\hline $\begin{array}{l}\text { Telen van vanggewassen en winter- } \\
\text { gewassen }\end{array}$ & $\begin{array}{l}\text { Het risico op } \mathrm{N}_{2} \mathrm{O} \text {-emissie neemt toe bij een bemest wintergewas } \\
\text { (groenbemester) door de stikstofbemesting. Een onbemest vanggewas neemt } \\
\text { stikstof op na de oogst van het hoofdgewas, waardoor het risico op } \mathrm{N}_{2} \mathrm{O} \text {-emissie } \\
\text { en nitraatuitspoeling in de winter afneemt. Het onderploegen van een winter- } \\
\text { en vanggewas kan leiden tot een toename van de } \mathrm{N}_{2} \mathrm{O} \text {-emissie. }\end{array}$ \\
\hline \multicolumn{2}{|l|}{ Achterlaten gewasresten } \\
\hline Stikstofrijk & $\begin{array}{l}\text { Stikstofrijke gewasresten zijn meestal gemakkelijk afbreekbaar en hebben een } \\
\text { lage } \mathrm{C} / \mathrm{N} \text {-verhouding. Er is duidelijk risico op toename van } \mathrm{N}_{2} \mathrm{O} \text {-emissie en } \\
\text { nitraatuitspoeling (indirecte } \mathrm{N}_{2} \mathrm{O} \text {-emissie) als deze gewasresten in de bodem } \\
\text { achterblijven. In de huidige praktijk blijven deze gewasresten meestal achter in } \\
\text { de bodem. }\end{array}$ \\
\hline Stikstofarm (o.a. stro) & $\begin{array}{l}\text { Het effect op } \mathrm{N}_{2} \mathrm{O} \text {-emissie is beperkt, omdat de organische stof relatief moeilijk } \\
\text { afbreekbaar is en de } \mathrm{C} / \mathrm{N} \text {-verhouding hoog is. Minerale stikstof in de bodem } \\
\text { wordt vastgelegd bij de vertering van stro, waardoor risico op nitraatuitspoeling } \\
\text { en (indirecte) } \mathrm{N}_{2} \mathrm{O} \text {-emissie lager wordt. Een deel van het stro wordt momenteel } \\
\text { afgevoerd na de oogst. }\end{array}$ \\
\hline \multicolumn{2}{|l|}{ Meer organische meststoffen } \\
\hline Drijfmest & $\begin{array}{l}\text { Het risico op } \mathrm{N}_{2} \mathrm{O} \text {-emissie neemt toe naarmate er meer drijfmest wordt } \\
\text { toegediend. Drijfmest bevat veel minerale } \mathrm{N} \text { en gemakkelijk afbreekbare } \mathrm{C} \text {. Er } \\
\text { is ook een risico op nitraatuitspoeling (indirecte } \mathrm{N}_{2} \mathrm{O} \text {-emissie). }\end{array}$ \\
\hline Vaste fractie na scheiden & $\begin{array}{l}\text { Het risico op } \mathrm{N}_{2} \mathrm{O} \text {-emissie is kleiner dan bij drijfmest. } \mathrm{Er} \text { is een risico op } \mathrm{N}_{2} \mathrm{O} \text { - } \\
\text { emissie, omdat de vaste fractie minerale } \mathrm{N} \text { en gemakkelijk afbreekbare } \mathrm{C} \\
\text { bevat. Ook risico op nitraatuitspoeling (indirecte } \mathrm{N}_{2} \mathrm{O} \text {-emissie) neemt toe. }\end{array}$ \\
\hline Digestaat & $\begin{array}{l}\text { Het risico op } \mathrm{N}_{2} \mathrm{O} \text {-emissie is vergelijkbaar met drijfmest. Door vergisting is het } \\
\text { gehalte aan minerale } \mathrm{N} \text { hoger en die van gemakkelijk afbreekbare } \mathrm{C} \text { lager dan } \\
\text { van drijfmest. } \mathrm{Er} \text { is een risico op een hogere } \mathrm{N}_{2} \mathrm{O} \text {-emissie. }\end{array}$ \\
\hline Stalmest & $\begin{array}{l}\text { Er is een risico op } \mathrm{N}_{2} \mathrm{O} \text {-emissie, maar lager dan bij drijfmest, vaste fractie en } \\
\text { digestaat, omdat stalmest minder minerale } \mathrm{N} \text { en gemakkelijk afbreekbare } \mathrm{C} \\
\text { bevat. }\end{array}$ \\
\hline Gft-Compost & $\begin{array}{l}\text { Risico op } \mathrm{N}_{2} \mathrm{O} \text {-emissie is kleiner dan bij drijfmest, omdat gft-compost minder } \\
\text { minerale } \mathrm{N} \text { en gemakkelijk afbreekbare } \mathrm{C} \text { bevat. }\end{array}$ \\
\hline Groencompost & $\begin{array}{l}\text { Risico op } \mathrm{N}_{2} \mathrm{O} \text {-emissie is lager dan de andere genoemde organische } \\
\text { meststoffen, omdat groencompost veel minder minerale } \mathrm{N} \text { en gemakkelijk } \\
\text { afbreekbare } \mathrm{C} \text { bevat. }\end{array}$ \\
\hline
\end{tabular}




\section{$7 \quad$ Gebruik van steenmeel in landbouw als optie voor negatieve $\mathrm{CO}_{2}$-emissies}

\section{$7.1 \quad$ Inleiding}

In verschillende publicaties is berekend dat het gebruik van silicaten op bodems, of meer specifiek op landbouwbodems, kan leiden tot vastlegging van $\mathrm{CO}_{2}$ uit de atmosfeer (Seifritz, 1990; Schuiling et al., 2006; Hartmann et al., 2008; Beerling et al., 2018). Het belangrijkste mechanisme dat hierbij genoemd wordt, is het verhogen van de $\mathrm{pH}$ van het bodemvocht, waardoor $\mathrm{CO}_{2}$ uit de lucht oplost in water en als bicarbonaat wordt getransporteerd naar de oceaan om daar vervolgens lang aanwezig te blijven in die vorm. Enigszins vergelijkbare opties betreffen het versnellen van de verwering van natuurlijke aanwezige silicaten (Kelemen et al., 2011) en het gebruik van silicaten in kustwateren (Hangx et al., 2009; Monsterrat et al., 2017); al deze opties worden samen vaak aangeduid als enhanced weathering (Schuiling et al., 2006).

De $\mathrm{CO}_{2}$-emissie als gevolg van het op peil houden van de $\mathrm{pH}$ van landbouwbodems met kalk wordt meegenomen in de nationale rapportages van het klimaatverdrag van de VN (UNFCCC) (Ruyssenaars et al., 2020). Het op peil houden van de bodem-pH met silicaten gebeurt weinig in de landbouw, maar is normaal in de natuur. Bij het oplossen van kalk $\left(\mathrm{CaCO}_{3}\right)$ in de bodem komt $\mathrm{CO}_{2}$ vrij in de vorm van $\mathrm{CO}_{2}$ als gas of opgelost in water $\left(\mathrm{HCO}_{3}{ }^{-}\right)$, waarbij het - afhankelijk van de bodem en hydrologische situatie - naar de zee wordt getransporteerd (West en Marland, 2002). Bij de verwering van silicaten komt geen $\mathrm{CO}_{2}$ vrij en wordt, net als bij kalk afhankelijk van de hydrologische situatie, wel $\mathrm{HCO}_{3}^{-}$naar de zee getransporteerd. Omdat in kalkloze landbouwbodems in het algemeen kalk gebruikt wordt om de $\mathrm{pH}$ geschikt te maken voor landbouwgewassen, is gebruik van silicaten potentieel een alternatief waardoor minder antropogene $\mathrm{CO}_{2}$-emissies optreden. In dit hoofdstuk wordt berekend hoeveel $\mathrm{CO}_{2}-$ emissie er plaatsvindt in Nederland indien silicaten gebruikt worden in de landbouw in plaats van kalk of hoeveel $\mathrm{CO}_{2}$ additioneel kan worden vastgelegd.

Een aantal studies heeft gewezen op het gebruik van silicaten op wereldschaal voor $\mathrm{CO}_{2}$-vastlegging (Beerling et al., 2020; Hartmann et al., 2008; Beerling et al., 2018; Moosdorf et al., 2014; Köhler et al., 2010; De Haan et al., 2013). Om te komen tot een optimale vastlegging, is echter een hogere bodem-pH nodig ( $\mathrm{pH} 8$ à 9) (De Haan et al., 2013) dan is gewenst voor landbouwgewassen $\left(\mathrm{pH} \mathrm{H}_{2} \mathrm{O}\right.$ 6 à 7)[12]. De kosten van de additionele silicaten voor $\mathrm{CO}_{2}$-vastlegging hebben dus geen landbouwkundig nut (Hartmann et al., 2008). De $\mathrm{CO}_{2}$-vastlegging door maximaal gebruik van silicaten op alle landbouwgronden van de wereld is berekend op 0,9\% van de totale antropogene emissies (Hartmann et al., 2008). Bovendien wordt in die publicaties aangenomen dat olivijn gebruikt kan worden. Er wordt wel gewaarschuwd voor de hoge gehalten aan nikkel en chroom (Beerling et al., 2018; Köhler et al., 2010; De Haan et al., 2013; Amann et al., 2020). De hoge nikkelgehalten zijn de reden dat olivijn in Nederland niet voldoet aan de meststoffenwet (Rietra et al., 2011) of de nieuwe Ewetgeving voor bemestingsproducten (EU 2019/2009). Olivijn heeft waarschijnlijk een hoog neutraliserend vermogen en kan relatief puur (>90\%) gemijnd worden. Voor een Nederlandse situatie is berekend dat de kosten 189 euro per ton $\mathrm{CO}_{2}$ zijn bij gebruik van olivijn op land (Bakker et al., 2012). De Wereldbank voorspelt dat de kosten voor koolstofvastlegging tussen de 80-120 euro per ton $\mathrm{CO}_{2}$ kost vanaf 2050 (Beerling et al., 2020). Voor Nederland ligt dit dus boven de marge. Beerling et al. (2020) concluderen dan ook dat steenmeel aantrekkelijker is voor economisch snelgroeiende landen zoals China, Indonesië, Brazilië en Mexico.

\subsection{Theorie}

De totale $\mathrm{CO}_{2}$-emissie door kalk in de Nederlandse landbouw is in de National Inventory Report opgenomen (Ruyssenaars et al., 2020) en bedraagt 0,0687 Mton $\mathrm{CO}_{2}$ eq (149 mln. $\mathrm{kg} \mathrm{CaCO}$ en $\mathrm{CaMg}\left(\mathrm{CO}_{3}\right)_{2}$ staat gelijk aan $75 \mathrm{mln}$. $\mathrm{kg} \mathrm{CaO}$ ) en dat is $0,04 \%$ van de totale antropogene emissie van 
195 Mton $\mathrm{CO}_{2}$ eq (excl. LULUCF voor het jaar 2015). De $\mathrm{CO}_{2}$-emissie door kalkgebruik, verdeeld over alle landbouwgrond in Nederland, is $0,038 \mathrm{t} \mathrm{CO}_{2}$ per ha. Aangezien vrijwel alle kalk op de bodem plaatsvindt bij bekalking van landbouwbodems (1,8 miljoen ha) betreft dat gemiddeld $38,2 \mathrm{~kg} \mathrm{CO}_{2}$ per ha.

De emissiefactor bij kalk is in de National Inventory Report gesteld op $120 \mathrm{~kg} \mathrm{C}$ per ton $\mathrm{CaCO}_{3}$, ofwel $440 \mathrm{~kg} \mathrm{CO}$ per ton $\mathrm{CaCO}_{3}$. Bedoeld wordt hier de emissie van $\mathrm{CO}_{2}$ vanuit de kalk zelf door het oplossen in de zure bodem (Biasi et al., 2008). De emissie door de productie, transport en verspreiden, is verwerkt in andere posten (industrie, energie). Die zogenoemde 'off-farm'-emissies zijn niet specifiek berekend door IPCC, maar behoren toe aan de sector industrie en transport. Om voor een product de specifieke emissies te berekenen, wordt bij LCA's wel de off-farm-emissies berekend. Hierdoor zijn veel verschillende berekeningen en schattingen in omloop die grote verschillen vertonen. Voor silicaten zijn weinig schattingen beschikbaar in LCA's.

De Verenigde Staten gebruikt in hun rapportage (EPA, 2005) een andere emissiefactor voor kalkgebruik in de landbouw: 59 i.p.v. bovengenoemde $120 \mathrm{~g} \mathrm{C}$ eq per kg kalk. De VS komen op de lagere emissie doordat ze het C-transport als bicarbonaat meenemen dat via bodems en rivieren naar oceanen gaat en daar wordt vastgelegd als kalk (West et al., 2005; Ogle et al., 2014). Als je die systematiek gebruikt, kun je ook een verhoogd gebruik bekalkende materialen deels verantwoorden, omdat meer bekalking leidt tot hogere bicarbonaatconcentratie in bodemvocht en daarmee vastlegging in oceanen. ${ }^{12} \mathrm{Bij}$ een relatief zure bodem wordt alle $\mathrm{C}$ uit kalk geëmitteerd als $\mathrm{CO}_{2}($ Biasi et al., 2008). Hoe hoger de $\mathrm{pH}$ van de bodem en het hele hydrologische systeem, hoe meer $\mathrm{C}$ getransporteerd wordt naar de oceaan (West en Marland, 2002).

\subsection{Mitigatie opties voor steenmeelgebruik}

\subsubsection{Optie 1. Gebruik silicaten in plaats van landbouwkalk, huidig kalkgebruik}

Als aangenomen wordt dat de productie en het uitrijden van silicaten evenveel off-farm-emissies geven als kalk, dan zijn alleen de 'on-farm' verschillen relevant. Bij silicaten komt geen $\mathrm{CO}_{2}$ vrij, bij kalk komt alle $\mathrm{CO}_{2}$ uiteindelijk vrij. Het verschil is dan eenvoudig: de totale $\mathrm{CO}_{2}$-emissie als gevolg van kalkgebruik in de landbouw (0,0687 Mton $\mathrm{CO}_{2}$ eq. in 2015 [8]) is te reduceren tot nul. Een gedetailleerdere berekening (Tabel 10) houdt rekening met het lagere neutraliserend vermogen van de silicaten ten opzichte van kalk. Op basis van metingen bevat landbouwkalk $50 \%$ neutraliserend vermogen. Bij silicaten is niet goed bekend of die definitie hanteerbaar is, omdat de verwering traag tot zeer traag gaat, afhankelijk van de mineralen. Als we grof aannemen dat alle $\mathrm{Ca}, \mathrm{Mg}, \mathrm{K}$ en $\mathrm{Na}$ in silicaten volledig verweren en neutraliseren zoals wollastoniet of olivijn, dan kunnen we $\mathrm{Ca}, \mathrm{Mg}, \mathrm{K}$ en $\mathrm{Na}$ toerekenen als neutraliserend vermogen. Op basis van de samenstelling van het silicaatproduct Eifelgold (Fragstein et al., 1988) is het neutraliserend vermogen op lange termijn dan 25\%. Op basis daarvan is de hoeveelheid silicaten dan $149 \times 50 / 25=298$ Mton materiaal. Als we aannemen dat de off-farm-emissie per ton bij de winning en transport van silicaten hetzelfde is als bij kalk, moet hiermee vanwege de verschillende hoeveelheden rekening worden gehouden. De off-farm-emissie van kalk varieert sterk in diverse datasets: 39, 89, 131, $140 \mathrm{~g} \mathrm{CO}_{2}$ eq per $\mathrm{kg} \mathrm{CaCO}$ (Edwards et al., 2016; Kool et al., 2012; West en Marland, 2002; O'Brien et al., 2014). In Tabel 10 wordt $89 \mathrm{~g} \mathrm{CO}_{2} \mathrm{~kg}$ materiaal gehanteerd (Kool et al., 2012).

Er kunnen ook redenen zijn om de off-farm-emissie van silicaten hoger of lager in te schatten. Ecoinvent (Nemecek and Kägi, 2007) neemt aan dat silicaten een reststof zijn bij de winning van steen waardoor de off-farm-emissie van steenmeel zeer laag is $\left(0,00262 \mathrm{~g} \mathrm{CO}_{2} \mathrm{eq}\right.$ per $\left.\mathrm{kg}\right) \mathrm{Bij}$ het gebruik van silicaten als alternatief is echter niet aannemelijk dat de hoeveelheid reststof voldoende is om aan de vraag te voldoen. Veel hogere off-farm-emissies worden aan silicaten toegekend als aangenomen wordt dat de materialen zeer fijn gemalen moeten worden $(0,010 \mathrm{~mm}): 200 \mathrm{~g} \mathrm{CO} \mathrm{eq} \mathrm{per}$ $\mathrm{kg}$ olivijnhoudend gesteente (Bakker et al., 2012). Anderen komen tot 77 à $227 \mathrm{~g} \mathrm{CO}$ eq per kg fijn

\footnotetext{
12 Bij landbouwkundig gebruikte zandgronden in Nederland vindt ook uitspoeling plaats van C uit kalk in de vorm van bicarbonaat (De Goffau et al., 2012).
} 
gemalen olivijn en 7 à $22 \mathrm{~g} \mathrm{CO}$ eq per kg voor transport (Köhler et al., 2010). Basaltwinning ten behoeve van steenwol is $140 \mathrm{gr} \mathrm{CO}$ eq per $\mathrm{kg}$ basalt (14\% van totale $\mathrm{CO}_{2}$-emissie van steenwol) (Flury et al., 2012).

De prijs in euro's voor dolokal en een goedkoop silicaat is ongeveer resp. 100 à 150 euro per ton (bij levering op boerderij excl. btw) (KWIN, 2012; Kijfeed, 2008). De reden dat een aantal boeren op dit moment de hogere prijs voor het silicaat betalen, is dat het gebruikt kan worden als stalstrooisel bij melkvee. Na het gebruik als strooisel komt het met de dierlijke mest op het land: het heeft dus twee functies. Daarnaast zijn er hypotheses dat diverse silicaten, naast een bekalkende werking, via diverse mechanismen kunnen bijdragen aan hogere gewasopbrengsten (Rietra et al., 2012; Van Balen et al., 2016; Anonymous, 2016; Van Eekeren et al., 2014). De meerprijs van silicaten i.p.v. kalk wordt dus door een deel van de boeren betaald. Het is onbekend welke prijs Nederlandse veehouders en akkerbouwers zouden willen betalen voor silicaten i.p.v. kalk, waardoor de meerkosten voor de negatieve emissie op dit moment slechts grof in te schatten zijn: als de meerprijs geheel toebedeeld wordt aan de kosten van negatieve emissie, dan zijn de kosten: 538 euro per $\mathrm{t} \mathrm{CO}_{2}$ eq. ${ }^{13}$ De totale negatieve emissie van 0,055 Mton $\mathrm{CO}_{2}$ is dan 0,03\% van de totale antropogene emissie van $\mathrm{NL}$ (is 212 Mton $\mathrm{CO}_{2}$ ).

Tabel 10 Vermindering $\mathrm{CO}_{2}$-emissie bij gebruik van silicaten als alternatief voor kalk in NL landbouw: bij huidige gebruik van kalk.

\begin{tabular}{llll} 
& Huidige situatie: & Alternatief: & Verschil: \\
& Kalk & Silicaten & Negatieve emissie \\
\hline Gebruik materiaal & 0,149 & Mton & Mton \\
\hline 'off-farm'-emissie $\left(\mathrm{CO}_{2} \mathrm{eq}\right)$ & $0,013^{*}$ & 0,298 & $0,027^{*}$ \\
\hline 'on-farm'-emissie $\left(\mathrm{CO}_{2} \mathrm{eq}\right)$ & 0,0687 & 0 & 0,055 \\
\hline Totale emissie $\left(\mathrm{CO}_{2} \mathrm{eq}\right)$ & 0,081 & 0,027 & $0,0 \mathrm{Mton}$ \\
\hline
\end{tabular}

$* 89 \mathrm{~g} \mathrm{CO}_{2}$ eq kg-1 kalk (Kool et al., 2012) x 0,149 Mton kalk =0,013 Mton $\mathrm{CO}_{2}$, en $89 \times 0,298$ Mton silicate $=0,0 \mathrm{Mton}^{\mathrm{CO}}$.

\subsubsection{Optie 2. Gebruik silicaten in plaats van landbouwkalk, waarbij kalkgift conform landbouwkundige adviezen}

Op dit moment is de kalkgift lager dan het advies. Volgens landbouwkundig laboratorium Eurofins Agro heeft een op de drie maispercelen een pH lager dan 5 (Eurofins, 2016) en heeft 30\% van het grasland een pH lager dan 5, wat beneden het advies is (Hogenkamp, 2013). Het is niet eenvoudig om op basis van die cijfers te berekenen wat de kalkgift zou moeten zijn indien het advies gevolgd zou worden, omdat het advies verschilt per bodem en de bodem-pH niet optimaal is. Aangenomen zou kunnen worden dat de hoogste kalkgift in het verleden past bij het landbouwkundig advies. Het kalkgebruik daalde tussen 1985 en 2010 (Wijsman, 2012). In de periode daarna zijn geen cijfers gepubliceerd, behalve in de National Inventory Report vanaf 1990 (Ruyssenaars et al., 2020). Die laat ook een daling zien van 1990 tot 2015 van 389 tot $150 \mathrm{mln}$. ton kalk. Het agrarisch landgebruik is in die periode gedaald met $15 \%$. Het kalkgebruik per ha is dus gedaald tot $46 \%$ in $2015(67 \mathrm{~kg} / \mathrm{ha} / \mathrm{j})$ t.o.v. 1990 (136 kg/ha/j). Als aangenomen wordt dat de kalkgift in 1990 past bij het landbouwkundig advies, dan is het geadviseerde kalkgebruik naar schatting 0,149 x 100/46 =0,329 Mton. Overigens is een gemiddeld kalkgebruik van $136 \mathrm{~kg} / \mathrm{ha} / \mathrm{jaar}$ nog relatief laag ten opzichte van het advies voor gras en mais: bijvoorbeeld $300 \mathrm{~kg}$ kalk onderhoudsbekalking bij grasland voor $\mathrm{pH} 5$ en $5 \%$ organische stof (Van Schooten et al., 2016). Dat komt o.a. doordat een deel van de Nederlandse landbouwbodems niet bekalkt wordt, omdat het kalkrijke bodems betreft.

Aangezien een hoger gebruik van kalk past bij landbouwkundige adviezen, kunnen daarbij hogere opbrengsten verwacht worden. De meerprijs zou dus door boeren betaald kunnen worden. Voor het gebruik van silicaten i.p.v. kalk geldt hetzelfde als bij scenario 1 . De totale negatieve emissie van

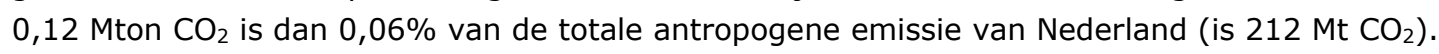

${ }^{13}(0,298$ Mton silicaat x 150€/t - 0,149 Mton kalk x $100 € / \mathrm{t}) /\left(\right.$ negatieve emissie $\left.0,055 \mathrm{Mt} \mathrm{CO}_{2}\right)=538 € / \mathrm{t} \mathrm{CO}_{2}$. 
Tabel 11 Vermindering $\mathrm{CO}_{2}$-emissie bij gebruik van silicaten als alternatief voor kalk in NL landbouw: bij landbouwkundig advies van kalk.

\begin{tabular}{llll} 
& Meer: & Alternatief: & Verschil: \\
Kalk & Mton & Nilicaten & Mton \\
Gebruik materiaal & 0,329 & 0,658 & \\
\hline 'off-farm'-emissie $\left(\mathrm{CO}_{2}\right.$ eq $)$ & 0,029 & 0,059 & \\
\hline 'on-farm'-emissie $\left(\mathrm{CO}_{2} \mathrm{eq}\right)$ & 0,149 & 0 & 0,12 \\
\hline Totale emissie $\left(\mathrm{CO}_{2} \mathrm{eq}\right)$ & 0,178 & 0,059 & \\
\hline
\end{tabular}

\subsubsection{Optie 3. Gebruik van silicaten boven landbouwkundige adviezen om zoveel mogelijk $\mathrm{CO}_{2}$ te binden}

Een methode om $\mathrm{CO}_{2}$ vast te leggen, is het verhogen van de bodem-pH zodat bij evenwicht met de bodemlucht een hoge concentratie bicarbonaat in bodemvocht en grondwater ontstaat. Dat is in theorie mogelijk door een grote hoeveelheid silicaten in de bodem te mengen. Om duidelijk te maken wat met $\mathrm{CO}_{2}$-vastlegging bedoeld wordt, is het nodig om enkele reactievergelijkingen te geven. In de reacties wordt wollastoniet gebruikt, een vrij uitzonderlijk gesteentemeel dat bestaat uit één mineraal: $\mathrm{CaSiO}_{4}$, vergelijkbaar met olivijn $\left(\mathrm{MgSiO}_{4}\right)$. Wollastoniet is ook gebruikt in recente veldexperimenten (Hague et al., 2020).

Als kalk (reactie 1) of een basisch silicaat zoals wollastoniet (reactie 2 ) in aanraking komt met lucht en water, kan het met $\mathrm{CO}_{2}$ uit de lucht reageren. $\mathrm{Het} \mathrm{CO}_{2}$ lost dan op in water en neemt dan de vorm aan van bicarbonaat $\left(\mathrm{HCO}_{3}{ }^{-}\right)$. Als het calcium of magnesium uitspoelt en uiteindelijk aankomt in de oceaan zal het uiteindelijk neerslaan als een carbonaat. Hierbij komt op den duur weer $\mathrm{CO}_{2}$ vrij. Netto levert de reactie van kalk daarom geen vastlegging van $\mathrm{CO}_{2}$ uit de lucht op. Tijdelijk wordt er wel $\mathrm{CO}_{2}$ geconsumeerd. De reactie van een basisch silicaat als wollastoniet consumeert in theorie per mol $\mathrm{CaSiO}_{4} 2 \mathrm{~mol} \mathrm{CO}_{2}$, maar na de vastlegging als kalk in de oceaan levert het netto $1 \mathrm{~mol} \mathrm{CO}_{2}$ vastlegging.

Toegevoegd aan bodem

$\mathrm{CaCO}_{3}(\mathrm{~s})+\mathrm{H}_{2} \mathrm{O}+\mathrm{CO}_{2}(\mathrm{~g}) \downarrow$ in bodemvocht en water

$$
->\mathrm{Ca}^{2+}+2 \mathrm{HCO}_{3}^{-->} \mathrm{CaCO}_{3}+\mathrm{CO}_{2}(\mathrm{~g}) \uparrow
$$

Via kalk $\left(\mathrm{CaCO}_{3}\right)$ wordt tijdelijk $\mathrm{CO}_{2}$ vastgelegd (1 mol $\mathrm{C}$ per mol $\mathrm{Ca}$ ), maar netto uiteindelijk in de oceaan niets.

$\mathrm{CaSiO}_{4}(\mathrm{~s})+\mathrm{H}_{2} \mathrm{O}+2 \mathrm{CO}_{2}(\mathrm{~g}) \downarrow \quad->\quad \mathrm{Ca}^{2+}+2 \mathrm{HCO}_{3}^{-}+\mathrm{H}_{4} \mathrm{SiO}_{4}->\quad \mathrm{CaCO}_{3}+\mathrm{CO}_{2}(\mathrm{~g}) \uparrow$

Via wollastoniet $\left(\mathrm{CaSiO}_{4}\right)$ wordt tijdelijk $\mathrm{CO}_{2}$ vastgelegd ( $2 \mathrm{~mol} \mathrm{C}$ per mol $\mathrm{Ca}$ ) en netto uiteindelijk $50 \%$ van het initieel geconsumeerde $\mathrm{CO}_{2}(1 \mathrm{~mol} \mathrm{C}$ per $1 \mathrm{~mol} \mathrm{Ca})$. Daarbij wordt aangenomen dat al het materiaal reageert met $\mathrm{CO}_{2}$ en dat er geen $\mathrm{CO}_{2}$ verloren gaat gedurende de lange weg naar de oceaan. Daarnaast zijn echter ook altijd andere reacties relevant, zoals het neutraliseren van zuur in de bodem waardoor de $\mathrm{pH}$ van de bodem toeneemt of zuur uit het gebruik van stikstofmeststoffen. Als kalk reageert met een overmaat aan zuur komt er $\mathrm{CO}_{2}$ vrij (reactie 3 ).

$\mathrm{CaCO}_{3}(\mathrm{~s})+2 \mathrm{HNO}_{3} \quad->\quad \mathrm{Ca}^{2+}+2 \mathrm{NO}_{3}^{-}+\mathrm{H}_{2} \mathrm{O}+\mathrm{CO}_{2}(\mathrm{~g}) \uparrow$

Hierbij komt alle $\mathrm{CO}_{2}$ uit kalk vrij: $1 \mathrm{~mol} \mathrm{C}$ per mol $\mathrm{Ca}$.

Bij het gebruik van een basisch silicaat als 'bekalking' komt geen $\mathrm{CO}_{2}$ vrij.

$\mathrm{CaSiO}_{4}(\mathrm{~s})+\mathrm{HNO}_{3} \quad->\quad \mathrm{Ca}^{2+}+2 \mathrm{NO}_{3}^{-}+\mathrm{H}_{4} \mathrm{SiO}_{4}$

Bij hoge giften van heel reactieve silicaten zoals wollastoniet of bij relatief droge omstandigheden, kan in de bodem $\mathrm{CaCO}_{3}$ ontstaan zoals reactie 2 (Haque et al., 2020). Het is onzeker of dit leidt tot Cvastlegging, omdat de vastgelegde $\mathrm{C}$ op lange termijn weer kan vrijkomen als de bodem verzuurt. 
In de praktijk kan kalk dus leiden tot netto tussen 0 en $1 \mathrm{~mol} \mathrm{CO}_{2}$ per mol Ca-emissie, dat hangt af van de $\mathrm{pH}$ van een bodem. 'Bekalking' met een silicaat kan dus leiden tot netto $\mathrm{CO}_{2}$-vastlegging tussen 0 en $1 \mathrm{~mol} \mathrm{CO}_{2}$. In een langdurig experiment (McIntire en Sterges, 1953) is bepaald hoeveel C jaarlijks kan worden vastgelegd in de vorm van $\mathrm{HCO}_{3}$ met een silicaat. Daarbij is $200 \mathrm{mmol}$ wollastoniet per $\mathrm{kg}$ grond in twee gronden gemengd (een vrij puur steenmeel $\mathrm{CaSiO}_{4}$ ) en is gedurende tien jaar de uitspoeling uit de bodem bepaald. De $\mathrm{pH}$ name daarbij toe van 5 tot 8 . De jaarlijkse uitspoeling bestond na één jaar uit $1 \mathrm{~mol} \mathrm{C}$ per mol $\mathrm{Ca}$, wat na tien jaar toenam tot 1,4 mol $\mathrm{C}$ per mol Ca. Het blijkt dus dat ook na tien jaar en een hoge $\mathrm{pH}$ de netto-reactie bestaat uit reactie 2 en 4 . Als dan ook nog de laatste reactie in de oceaan (zie vergelijking 2) wordt meegenomen waarbij weer de helft van de $\mathrm{CO}_{2}$ vrijkomt, dan is de nettovastlegging na tien jaar 0,7 mol C per $1 \mathrm{~mol} \mathrm{Ca}$. Netto is de vastlegging per $\mathrm{mol} \mathrm{CaSiO}_{4}$ dus niet ideaal zoals in vergelijking 2. Ook in een recent veldexperiment bleek de $\mathrm{CO}_{2}$-vastlegging laag, waarschijnlijk vanwege $\mathrm{pH}$-buffering door de bodem (Amann et al., 2020). Vrijwel alle scenario's (Hartmann et al., 2008; Hartmann et al., 2013) gaan voor het gemak wel uit van een ideale of maximale reactie.

Behalve de genoemde oude studies van McIntire en Sterges (1953) is het mengen van silicaten door de grond om een hoge $\mathrm{pH}$ in bodemvocht te krijgen zelden in de praktijk getoetst. Dat is niet vreemd, omdat ook bij bekalken van grond het verspreiden van de hoge $\mathrm{pH}$ zeer traag gaat omdat een relatief zure bodem veel neutralisering vergt. Bijvoorbeeld bij een zeer hele hoge bekalking van een landbouwgrond met 40 ton $\mathrm{CaO}$ equivalent ha-1 nam de $\mathrm{pH}$ na negen jaar in de bovengrond toe van 5,5 tot 7,5. Echter, de hoge bekalking had na negen jaar geen effect op de $\mathrm{pH}$ op $60 \mathrm{~cm}$ diepte. Pas na 23 jaar was de pH in de ondergrond op $60 \mathrm{~cm}$ toegenomen van 5,8 naar 6,3 (Brown et al., 1956). Dit geeft aan dat heel veel silicaten, of kalk, nodig is om de bodem te neutraliseren voordat het grondwater bereikt wordt op een bepaalde diepte.

Bij het idee om met silicaten $\mathrm{CO}_{2}$ vast te leggen in landbouwbodems is in Nederland vaak specifiek olivijn genoemd (Schuiling en Krijgsman, 2006). Olivijn bevat van nature echter zeer hoge gehalten nikkel (2655 mg N kg-1) en chroom (1538 mg Cr kg-1), overschrijdt daarmee Nederlandse normen in Meststoffenwet, en ook de voorgestelde normen in de EU voor meststoffen (voorgestelde EU-norm voor nikkel is $120 \mathrm{mg} \mathrm{Ni} \mathrm{kg}^{-1}$ ) (Smolders et al., 2009). De reden voor dergelijke normen is o.a. omdat nikkel al bij relatief lage toevoegingen toxisch is voor bodemorganismen (Alloway, 2008). Er zijn ook andere steenmelen van basalt of andere gesteenten die gebruikt kunnen worden (Beerling et al., 2018; Rietra et al., 2012).

Om veel bicarbonat in grondwater te krijgen, is een hoge $\mathrm{pH}$ nodig in de bodem en daarna in grondwater. Bijvoorbeeld de $\mathrm{pH}$ zoals in evenwicht bij kalk $(\mathrm{pH} 8)$ of een $\mathrm{pH}$ zoals die wel in basaltgesteenten wordt gevonden $(\mathrm{pH}>8)$. Een hoge $\mathrm{pH}$ is landbouwkundig echter niet gewenst. Veel landbouwgewassen hebben een optimumgroei bij neutrale $\mathrm{pH}^{\prime} \mathrm{s}$ ( $\mathrm{pH} 6$ à 7), o.a. omdat bij hoge pH's de beschikbaarheid vanuit de bodem van diverse nutriënten ( $B, C u, F e, M n, Z n, N i)$ minder goed is (EC, 2016).

Ondanks bovengenoemde praktische bezwaren, de voor de landbouw ongewenste hoge $\mathrm{pH}$ van de bodem en de risico's op hoge nikkel- en chroomgehalten in de bodem bij gebruik van olivijn, is een aantal scenario's doorgerekend in enkele publicaties (Hartmann et al., 2008; De Haan et al., 2013; Beerling et al., 2020), zodat bekend is wat het potentiële effect op $\mathrm{CO}_{2}$-vastlegging is bij het verspreiden van silicaten over alle landbouwbodems of over al het land in de wereld.

In Hartmann et al. (2008) is berekend dat als silicaten over alle land- en bosbouwgebieden van de aarde verspreid zouden worden, bij hoeveelheden de passen bij normale landbouw, dit zou leiden tot een netto $\mathrm{CO}_{2}$-vastlegging van $0,0065 \mathrm{Pg} \mathrm{C} \mathrm{j}^{-1}(0,1 \%$ van de antropogene emissies). Een meer extreem scenario kan ook vrij eenvoudig berekend worden. Als je aanneemt dat via silicaten de $\mathrm{pH}$ van alle bodems en van alle rivieren verhoogd wordt tot de $\mathrm{pH}$ van de rivier met de hoogste $\mathrm{pH}(\mathrm{pH} 8$ zoals de Seine in Frankrijk), dan heb je de maximale $\mathrm{HCO}_{3}$ die naar de oceanen getransporteerd kan worden. Op dit moment stroomt via de grote rivieren in de wereld (Gaillardet et al., 1999) $19926 \mathrm{~km}^{3}$ per jaar met een gemiddelde bicarbonatconcentratie van 1 mmol L-1 $\mathrm{HCO}_{3}-\mathrm{C}$, (min.-max.: 0,164 t.o. 4,1 ), wat resulteert in $0,24 \mathrm{Pg} \mathrm{C} \mathrm{jr}^{-1}$. De hoogste bicarbonaatconcentratie in een grote rivier is $4,1 \mathrm{mmol} \mathrm{I}^{-1}$. Als alle rivieren zoveel bicarbonaat zouden bevatten als de Seine, wordt 0,74 Pg C naar 
de oceanen getransporteerd. Dat is een relevante hoeveelheid ten opzichte van jaarlijkse antropogene emissies van 7,2 $\mathrm{Pg} \mathrm{C} \mathrm{yr}^{-1}$ (Denman et al., 2007), maar het is duidelijk dat via een zeer extreem scenario (alle bodems van de wereld naar $\mathrm{pH} 8$ ) nog steeds maar een klein deel van de antropogene emissies vastgelegd wordt. Vergelijkbaar daarmee is een modelberekening waarin $0,6 \mathrm{Pg} \mathrm{C} \mathrm{j}^{-1}(8 \%$ van antropogene emissie) wordt vastgelegd als de $\mathrm{pH}$ van de twee belangrijkste rivierbekkens op aarde (hele Congo en Amazone bekken) wordt verhoogd naar pH 8,2 (Kohler en Harmann, 2010). In een ander scenario wordt de $\mathrm{pH}$ van alle landbouwgronden sterk verhoogd door de toepassing van $2 \mathrm{~mm}$ steenmeel per jaar wat zou kunnen leiden tot een C-vastlegging van $0,14-0,55 \mathrm{Pg} \mathrm{C} \mathrm{j}^{-1}(2-8 \%$ van antropogene emissies). De kosten zijn geschat op US\$80-180 per ton $\mathrm{CO}_{2}$ (Beerling et al., 2020).

Het oplossen van silicaten zou naast $\mathrm{CO}_{2}$-vastlegging via bicarbonaat ook andere voordelen kunnen hebben en daarmee potentieel kunnen leiden tot meer $\mathrm{CO}_{2}$-vastlegging, maar daarvan zijn geen schattingen bekend (extra Si in zee (Hartmann et al., 2013), minder afbraak van bodem organische stof door sterkere binding in de bodem (Beerling et al., 2018)). Naast de genoemde optie op land zijn andere opties voor silicaten gemodelleerd zoals het gebruik van silicaten in zee, maar dat is geen onderdeel van dit hoofdstuk (Hauck et al., 2016; Griffioen et al., 2017; Montserrat et al., 2017).

\subsection{Conclusies}

De toepassing van silicaten in plaats van kalk wordt door sommige boeren gebruikt vanwege mogelijke bodemverbeterende eigenschappen. Silicaten verhogen de bodem-pH zoals kalk dat doet, maar bevatten geen $\mathrm{C}$ en leiden daarom niet tot $\mathrm{CO}_{2}$-emissies. Berekend is de $\mathrm{CO}_{2}-$ emissievermindering bij gebruik van silicaten in de plaats van kalk. De $\mathrm{CO}_{2}$-emissies van Nederland zouden bij het huidige kalkgebruik, of bij het geadviseerde gebruik van landbouwkalk, kunnen dalen met resp. 0,055 en 0,12 Mton $\mathrm{CO}_{2}$. Omdat een aantal boeren nu al silicaten gebruikt, variëren de kosten van 0 euro per $\mathrm{t} \mathrm{CO}_{2}$ tot 538 euro per ton $\mathrm{CO}_{2}$ in het geval aan silicaten geen enkele meerwaarde wordt toegekend t.o.v. het neutraliserend vermogen. De kosten van deze optie hangen dus voornamelijk af van de waarde die boeren toekennen aan silicaten voor bodemverbetering en bemesting.

Een andere optie is om veel meer silicaten te gebruiken dan landbouwkundig nodig is, om daarmee maximaal $\mathrm{CO}_{2}$ vast te leggen. Het potentiaal van het verspreiden van silicaten zoals olivijn over alle landbodems van de aarde is berekend op 0,9\% van alle antropogene emissies. Daarbij wordt verondersteld dat ook alle ontoegankelijke bodems en alle bossen van de wereld bemest worden met een laag gemalen silicaten. Schattingen van het potentiële effect van het verspreiden van silicaten over alle landbouwbodems lopen uiteen van 0,1 (Hartmann et al., 2008) tot 2 à $8 \%$ (Beerling et al., 2020) van de antropogene emissies, afhankelijk van de gift aan steenmeel per ha en de gevolgen op rivieren. Dergelijke scenarioberekeningen bevatten veel onzekerheden (Moosdorf et al., 2014). 


\section{Algemene conclusies en aanbevelingen}

In het Klimaatakkoord is afgesproken om in 2030 een extra 0,4-0,6 Mton $\mathrm{CO}_{2}$-vastlegging in de Nederlandse landbouwgrond te realiseren. Deze studie laat zien dat de technische potentie voor koolstofvastlegging in landbouwbodems ongeveer 0,9 Mton $\mathrm{CO}_{2}$ per jaar is. Er is echter niet één enkele, individuele maatregel die tot het gewenste doel leidt en dus is een combinatie of stapeling van maatregelen nodig. Uiteindelijk zullen economische factoren voor een groot deel bepalen of de maatregelen in de praktijk toegepast gaan worden, aangezien veel maatregelen leiden tot extra kosten.

Voor de grondgebonden veehouderij hebben maatregelen die het omzetten van tijdelijk grasland en snijmais naar permanent grasland stimuleren de hoogste potentie als het gaat om $\mathrm{CO}_{2}$-vastlegging. In de akkerbouw wordt het zaaien van een vanggewas/groenbemester na de oogst gezien als een maatregel met een hoge potentie en daarnaast ook het verhogen van het aandeel rustgewassen in de rotatie. Op basis van recente literatuur en uitkomsten van langetermijnexperimenten uit Slim Landgebruik blijkt dat niet-kerende grondbewerking onder Nederlandse omstandigheden niet bijdraagt aan netto $\mathrm{CO}_{2}$-vastlegging. Wel blijft niet-kerende grondbewerking een maatregel met positieve effecten op de bodemstructuur.

De potentie van de maatregelen zijn gebieds- en/of sectorafhankelijk en daarom wordt aanbevolen om bij het implementeren van maatregelen uit te gaan van bedrijfsspecifiek aanbevelingen en dito berekeningen van de potentiële $\mathrm{CO}_{2}$-vastlegging. In de berekeningen voor de potentiële $\mathrm{CO}_{2}{ }^{-}$ vastlegging is uitgegaan van de bodem-C-balans voor één jaar. Een toename in het organischestofgehalte van de bodem kan doorgaan tot de bodem weer een nieuw evenwicht bereikt tussen aanvoer en afbraak. De potentie voor koolstofvastlegging in de bodem als negative carbon technology is dus in principe tijdelijk. De potentie loopt terug naar nul, maar kan de eerstkomende decennia zeker bijdragen aan het realiseren van de doelen voor klimaatneutraliteit. Voor die bijdrage zijn talloze maatregelen die perspectiefvol zijn en realiseerbaar zijn zonder grote risico's. Wel is het verstandig om de effectiviteit van de verschillende maatregelen onder relevante condities goed te blijven monitoren.

Het verhogen van het organischestofgehalte in de bodem heeft ook effect op de stikstofkringloop en daarmee op de emissie van het broeikasgas lachgas $\left(\mathrm{N}_{2} \mathrm{O}\right)$. Uit de literatuurstudie komt naar voren dat toediening van organische stof kan leiden tot een toename van $\mathrm{N}_{2} \mathrm{O}$-emissie door het toevoegen van gemakkelijke afbreekbare organische stof als energiebron voor denitrificerende bacteriën en een verhoogde zuurstofconsumptie door afbraak van organische stof. Het effect van specifieke maatregelen op $\mathrm{N}_{2} \mathrm{O}$-emissies is echter wisselend en hangt sterk af van het huidige gewas- en bodembeheer. Bij toepassing van meststoffen en gewasresten met een hoge $\mathrm{C} / \mathrm{N}$-ratio (dus weinig stikstof) is het risico op lachgasemissie zeer beperkt.

Naast $\mathrm{CO}_{2}$-vastlegging in landbouwbodems zijn er ook mogelijkheden binnen de landbouw om $\mathrm{CO}_{2}$ vast te leggen in biomassa. Landschapselementen, zoals houtwallen, kunnen potentieel een grote bijdrage leveren aan koolstofvastlegging. Vergroten van het aandeel landschapselement naar $1 \%$ van het landbouwareaal leidt tot een potentiële $\mathrm{CO}_{2}$-vastlegging van 0,4 Mton $\mathrm{CO}_{2}$ per jaar. Dit betekent echter wel een verviervoudiging van het huidige areaal landschapselementen. De bijdrage aan netto $\mathrm{CO}_{2}$-vastlegging is ook maar tijdelijk, zolang de biomassa in de landschapselementen toeneemt. Ook agroforestry, het toepassen van houtige, meerjarige gewassen binnen een landbouwperceel, kan bijdragen aan $\mathrm{CO}_{2}$-vastlegging. Het Masterplan Agroforestry streeft ernaar om in 203025.000 ha landbouwgrond in te richten als agroforestry in Nederland. Als dit gerealiseerd zou worden, resulteert dit in een gemiddelde vastlegging van ongeveer 0,1 Mton $\mathrm{CO}_{2} /$ jaar.

Een laatste optie die in deze studie is verkend, is het gebruik van steenmeel (silicaten) ter vervanging van kalk in de landbouw. Silicaten zoals olivijn verhogen de bodem-pH zoals kalk, maar bevatten geen 
$\mathrm{C}$ en leiden daarom niet tot $\mathrm{CO}_{2}$-emissies. De $\mathrm{CO}_{2}$-emissies van Nederland zouden bij het huidige kalkgebruik, of bij het geadviseerde gebruik van landbouwkalk, kunnen dalen met resp. 0,055 en 0,12 Mton $\mathrm{CO}_{2}$ per jaar. Daarnaast is het ook een optie om veel meer silicaten te gebruiken dan landbouwkundig nodig is om daarmee maximaal $\mathrm{CO}_{2}$ vast te leggen. Schattingen van het potentiële effect lopen sterk uiteen en grootschalige toepassing lijkt vanwege de kosten en mogelijke vervuiling met zware metalen geen realistische optie in de Nederlandse landbouw. 


\section{Literatuur}

Abdalla, M., Hastings, A., Cheng, K., Yue, Q., Chadwick, D., Espenberg, M., Truu, J., Rees, R.M., Smith, P. 2019. A critical review of the impacts of cover crops on nitrogen leaching, net greenhouse gas balance and crop productivity. Global Change Biology 25, 2530-2543.

Alloway, B.J. 2008. Micronutrient deficiencies in global crop production: Springer Science \& Business Media.

Amann, T. et al. 2020. Enhanced Weathering and related element fluxes-A cropland mesocosm approach. Biogeosciences 17, 103-119.

Anonymous. Steenmeelproject Veenkoloniën. Steenmeel als duurzame bodemverbeteraar. http://steenmeel.info/steenmeel_veenkolonien.pdf: Steenmeel.info, De Biogeoloog, Carpay Advies; 2016.

Baah-Acheamfour, M., Chang, S. X., Bork, E. W., \& Carlyle, C.N. 2017. The potential of agroforestry to reduce atmospheric greenhouse gases in Canada: Insight from pairwise comparisons with traditional agriculture, data gaps and future research. The Forestry Chronicle, 93(2): 180-189.

Baggs, E.M., Rees, R.M., Smith, K.A., Vinten, A.J.A. 2000. Nitrous oxide emission from soils after incorporating crop residues. Soil Use and Management 16(2): 82-87.

Baggs, EM, Stevenson, M, Pihlatie, M, Regar, A, Cook, H, Cadisch, G. 2003. Nitrous oxide emissions following application of residues and fertiliser under zero and conventional tillage. Plant and Soil 254 (2): 361-370. 10.1023/a:1025593121839

Baker, J. M., Ochsner, T. E., Venterea, R. T., \& Griffis, T. J. (2007). Tillage and soil carbon sequestration-What do we really know? Agriculture, ecosystems \& environment, 118(1-4), 1-5.

Bakker D, Beumer V, Hartog N, Snijders W, Sule M, Vink J. Toepassing van olivijn in rws-werken. Inventarisatie van mogelijkheden voor een pilot. rapport nr 1203661-000: Deltares; 2012.

Basche, A.D., Miguez, F.E., Kaspar, T.C., Castellano, M.J. 2014. Do cover crops increase or decrease nitrous oxide emissions? a meta-analysis. Journal of Soil and Water Conservation 69, 471-482.

Basso, B, Ritchie, JT (2005) Impact of compost, manure and inorganic fertilizer on nitrate leaching and yield for a 6-year maize-alfalfa rotation in Michigan. Agriculture Ecosystems \& Environment 108 (4), 329-341. 10.1016/j.agee.2005.01.011

Beerling DJ, Leake JR, Long SP, Scholes JD, Ton J, Nelson PN, et al. Farming with crops and rocks to address global climate, food and soil security. Nature plants. 2018:1.

Beerling, D.J., Kantzas, E.P., Lomas, M.R., Wade, P., Eufrasio, R.M., Renforth, P., Sarkar, B., Andrews, M.G., James, R.H., Pearce, C.R. and Mercure, J.F., 2020. Potential for large-scale $\mathrm{CO}_{2}$ removal via enhanced rock weathering with croplands. Nature, 583(7815): 242-248.

Bell, MJ, Hinton, N, Cloy, JM, Topp, CFE, Rees, RM, Cardenas, L, Scott, T, Webster, C, Ashton, RW, Whitmore, AP, Williams, JR, Balshaw, H, Paine, F, Goulding, KWT, Chadwick, DR. 2015. Nitrous oxide emissions from fertilised UK arable soils: Fluxes, emission factors and mitigation. Agriculture Ecosystems \& Environment 212: 134-147. 10.1016/j.agee.2015.07.003

Bertora, C, Alluvione, F, Zavattaro, L, van Groenigen, JW, Velthof, G, Grignani, C (2008) Pig slurry treatment modifies slurry composition, $\mathrm{N}_{2} \mathrm{O}$, and $\mathrm{CO}_{2}$ emissions after soil incorporation. Soil Biology \& Biochemistry 40 (8), 1999-2006. 10.1016/j.soilbio.2008.03.021

Biasi C, Lind SE, Pekkarinen NM, Huttunen JT, Shurpali NJ, Hyvönen NP, et al. Direct experimental evidence for the contribution of lime to $\mathrm{CO}_{2}$ release from managed peat soil. Soil Biology and Biochemistry. 2008;40(10):2660-9.

Bijay, S, Ryden, JC, Whitchead, D.C. 1988. Some relationships between denitrification potential and fractions of organic carbon in air-dried and field-moist soils. Soil Biology and Biochemistry 20 (5), 737-741. https://doi.org/10.1016/0038-0717(88)90160-5

Blanco-Canqui, H., Shaver, T.M., Lindquist, J.L., Shapiro, C.A., Elmore, R.W., Francis, C.A., Hergert, G.W. 2015. Cover crops and ecosystem services: Insights from studies in temperate soils. Agronomy Journal 107, 2449-2474.

Boosten, M., van den Briel, J., Lerink, B., Lokin, V., \& Schelhaas, M. (2020). Factsheets Klimaatmaatregelen met bomen, bos en natuur: Praktische handreiking voor effectief klimaatslim bos-en natuurbeheer en toepassing van hout. 
Bos, J, ten Berge, HFM, Verhagen, J, van Ittersum, M.K. 2017. Trade-offs in soil fertility management on arable farms. Agricultural Systems 157 292-302. 10.1016/j.agsy.2016.09.013

Brienza, C., Sigurnjak, I., Meier, T., Michels, E., Adani, F., Schoumans, O., Vaneeckhaute, C., Meers, E., 2021. Techno-economic assessment at full scale of a biogas refinery plant receiving nitrogen rich feedstock and producing renewable energy and biobased fertilisers. Journal of Cleaner Production 308: 127408. doi: 10.1016/j.jclepro.2021.127408.

Brown BA, Munsell RI, Holt RF, King AV. 1956. Soil Reactions at Various Depths as Influenced by Time Since Application and Amounts of Limestone1. Soil Science Society of America Journal. 1956, 20: 518-22.

Bruggen, C. van, Bannink, A, Groenestein, CM, Huijsmans, JFM, Luesink, HH, Sluis, SMvd, Velthof, GL, Vonk, J. 2018. Emissies naar lucht uit de landbouw in 2016: berekeningen met het model NEMA. Wettelijke Onderzoekstaken Natuur \& Milieu: Wageningen.

Burford, JR, Bremner, JM (1975) Relationships between the denitrification capacities of soils and total, water-soluble and readily decomposable soil organic matter. Soil Biology and Biochemistry 7 (6), 389-394. https://doi.org/10.1016/0038-0717(75)90055-3

BVOR, 2017. Compost: effectieve organische stof in de bodem; marktcijfers 2016. BVOR.

Byrne, K. \& Kiely, G., 2009. Evaluation of Models (PaSim, RothC, CENTURY and DNDC) for Simulation of Grassland Carbon Cycling at Plot, Field and Regional Scale.

Cambier, P, Pot, V, Mercier, V, Michaud, A, Benoit, P, Revallier, A, Houot, S (2014) Impact of longterm organic residue recycling in agriculture on soil solution composition and trace metal leaching in soils. Science of the Total Environment 499 560-573. https://doi.org/10.1016/j.scitotenv.2014.06.105

Camia, A., Robert, N., Johnsson, R., Pili, R., Garcia-Condado, S., Lopez-Lozano, R., van der Velde, M., Ronzon, T., Gurria, P., M’Barek, R., Tamosiunas, S., Fiore, G., Araujo, R., Hoepffner, N., Marelli, L., Giuntoli, J., (2018) Biomass Production, supply, uses and flows in the European Union. First results from an integrated assessment, EUR 28993 EN. Publications Office of the European Union, Luxembourg.

Cardinael, R., Chevallier, T., Cambou, A., Beral, C., Barthès, B. G., Dupraz, C., ... \& Chenu, C. (2017). Increased soil organic carbon stocks under agroforestry: A survey of six different sites in France. Agriculture, Ecosystems \& Environment, 236, 243-255.

CBS Statline. https://opendata.cbs.nl/\#/CBS/nl/dataset/81302ned/table. Geraadpleegd op 27-01-2021.

CBS, 2016. Voor het eerst in 9 jaar meer blijvend grasland. https://www.cbs.nl/nlnl/nieuws/2016/21/voor-het-eerst-in-9-jaar-meer-blijvend-grasland

Chalk, PM, Smith, CJ (1983) Chemodenitrification. In: Freney, J.R., Simpson, J.R. (Eds.), Gaseous loss of nitrogen from plant-soil systems. Developments in Plant and Soils Sciences 9 65-89.

Chao W., Yujia T., Xiaona L., Weiwei Z., Chunqiao Z., Cui L. (2020) Environ. Res. Lett., 15: 104055.

Chen, H, Li, X, Hu, F, Shi, W (2013) Soil nitrous oxide emissions following crop residue addition: a meta-analysis. Global Change Biology 19 (10), 2956-2964. doi:10.1111/gcb.12274

Clayton, H, McTaggart, IP, Parker, J, Swan, L, Smith, KA (1997) Nitrous oxide emissions from fertilised grassland: A 2-year study of the effects of $\mathrm{N}$ fertiliser form and environmental conditions. Biology and Fertility of Soils 25 (3), 252-260. 10.1007/s003740050311

Coleman, K. en D.S. Jenkinson, 2014. RothC - A model for the turnover of carbon in soil - Model description and users guide (Windows version) (Updated June 2014). Rothamsted Research, Harpenden, UK.

Coleman, K., Jenkinson, D.S., Crocker, G.J., Grace, P.R., Klir, J., Korschens, M., Poulton, P.R., Richter, D.D., 1997. Simulating trends in soil organic carbon in long-term experiments using RothC-26.3. Geoderma 81, 29-44.

Conant, RT, Paustian, K, Del Grosso, SJ, Parton, WJ (2005) Nitrogen pools and fluxes in grassland soils sequestering carbon. Nutrient Cycling in Agroecosystems 71 (3), 239-248. 10.1007/s10705004-5085-z

Conijn, J.G., J.P. Lesschen. 2015. Soil organic matter in the Netherlands; Quantification of stocks and flows in the top soil. Wageningen, Wageningen UR (University \& Research centre), PRI report 619 / Alterra report 2663.

Crittenden, S. J., Poot, N., Heinen, M. D. J. M., Van Balen, D. J. M., \& Pulleman, M. M. (2015). Soil physical quality in contrasting tillage systems in organic and conventional farming. Soil and Tillage Research, 154, 136-144. 
de Boer, J., Oosterbaan, A., 2004. Op weg naar een duurzaam elzensingellandschap; Voorstudie naar haalbaarheid van verbreding van elzensingels. Wageningen, Alterra, Alterra-rapport 1085.

de Deyn, G.B., Quirk, H., Yi, Z., Oakley, S., Ostle, N.J., Bardgett, R.D. 2009. Vegetation composition promotes carbon and nitrogen storage in model grassland communities of contrasting soil fertility. Journal of Ecology, 97: 864-875.

de Goffau A, Doornewaard G, Fraters B. 2012. Landelijk Meetnet effecten Mestbeleid. Resultaten 2007 en 2008. RIVM Rapport 680717031. Bilthoven: RIVM.

de Haan J, Van Geel W. 2013. Adviesbasis voor de bemesting van akkerbouw-en vollegrondsgroentengewassen. Praktijkonderzoek Plant \& Omgeving BV.

de Stefano, A., \& Jacobson, M. G. (2018). Soil carbon sequestration in agroforestry systems: a metaanalysis. Agroforestry systems, 92(2), 285-299.

de Wit, J., van der Goor, S., Pijlman, J. en van Eekeren, N. 2018. Opbouw organische stof met blijvend grasland. V-Focus, april 2018, 32-24.

Diacono, M, Montemurro, F. 2010. Long-term effects of organic amendments on soil fertility. A review. Agronomy for Sustainable Development 30 (2), 401-422. 10.1051/agro/2009040

EC. Pakket Circulaire Economie. 2016. Voorstel voor een Verordening van het Europees parlement en de raad tot vaststelling van voorschriften inzake het op de markt aanbieden van bemestingsproducten met CE-markering en tot wijziging van de Verordeningen (EG) nr 1069/2009 en (EG) nr 1107/2009.

EC, 2020. Working with Parliament and council to make the CAP reform fit for the European Green Deal. Factsheet https://ec.europa.eu/info/sites/default/files/food-farmingfisheries/key_policies/documents/factsheet-cap-reform-to-fit-european-green-deal_en.pdf.

Edmeades, D.C. 2003. The long-term effects of manures and fertilisers on soil productivity and quality: a review. Nutrient Cycling in Agroecosystems 66 (2), 165-180. 10.1023/a:1023999816690

Edwards R, O'Connell A, Padella M, Mulligan D, Giuntoli J, Agostini A, et al. Definition of input data to assess GHG default emissions from biofuels in EU legislation. JRC Science for Policy Report EUR. $2016 ; 26853$.

EPA. Inventory of U.S. Greenhouse Gas Emissions and Sinks: 1990-2016. EPA 430-R-18-003. https://www.epa.gov/sites/production/files/2018-01/documents/2018_complete_report.pdf2018.

Erhart, E, Feichtinger, F, Hartl, W. 2007. Nitrogen leaching losses under crops fertilized with biowaste compost compared with mineral fertilization. Journal of Plant Nutrition and Soil Science 170 (5), 608-614. doi:10.1002/jpln.200625181

Eurofins. 2016. Nog veel maisland met een te lage pH. http://eurofins-agro.com/nl$\mathrm{nl}$ /expertise/bemesting/artikelen/nog-veel-maisland-met-een-te-lage-ph.

Firestone, M.K. 1982. Biological denitrification. In: Stevenson, F.J. (Ed.), Nitrogen in agricultural soils. Agronomy (22), 289-326.

Firestone, MK, Davidson, EA, Andreae, MO, Schimel, D.S. 1989. Exchange of trace gases between terrestrial ecosystems and the atmosphere: report of the Dahlem workshop on exchange of trace gases between terrestrial ecosystems and the atmosphere. Microbiological basis of $\mathrm{NO}$ and $\mathrm{N}_{2} \mathrm{O}$ production and consumption in soil. Wiley: New York, NY.

Flury K, Frischknecht R, Flumroc A. Life cycle assessment of rock wool insulation. ESU-services, Uster. 2012.

Foley, J.A., Ramankutty, N., Brauman, K.A., Cassidy, E.S., Gerber, J.S., Johnston, M., Mueller, N.D., O'Connell, C., Ray, D.K., West, P.C., Balzer, C., Bennett, E.M., Carpenter, S.R., Hill, J., Monfreda, C., Polasky, S., Rockström, J., Sheehan, J., Siebert, S., Tilman, D., Zaks, D.P.M. (2011) Solutions for a cultivated planet. Nature 478, 337-342.

Fornara, D. A., Wasson, E. A., Christie, P., \& Watson, C. J. (2016). Long-term nutrient fertilization and the carbon balance of permanent grassland: any evidence for sustainable intensification? Biogeosciences, 13(17), 4975-4984.

Fragstein PV, Pertl W, Vogtmann H. Verwitterungsverhalten silikatischer Gesteinsmehle unter Laborbedingungen. Zeitschrift für Pflanzenernährung und Bodenkunde. 1988;151(2):141-6.

Freibauer, A., Rounsevell, M.D.A., Smith, P., Verhagen, J. (2004) Carbon sequestration in the agricultural soils of Europe. Geoderma 122, 1-23.

García-Condado, S., López-Lozano, R., Panarello, L., Cerrani, I., Nisini, L., Zucchini, A., Van der Velde, M., Baruth, B. 2019. Assessing lignocellulosic biomass production from crop 
residues in the European Union: Modelling, analysis of the current scenario and drivers of interannual variability. GCB Bioenergy, 11: 809-831.

Geerts, R., Korevaar, H., Timmerman, A. 2014. Brochure: Kruidenrijk grasland, Meerwaarde voor vee, bedrijf en weidevogels.

Griffioen, J. Enhanced weathering of olivine in seawater: The efficiency as revealed by thermodynamic scenario analysis. Science of the Total Environment. 2017;575:536-44.

Gu, JX, Yuan, MX, Liu, JX, Hao, YX, Zhou, YT, Qu, D, Yang, XY (2017) Trade-off between soil organic carbon sequestration and nitrous oxide emissions fromwinter wheat-summer maize rotations: Implications of a 25-year fertilization experiment in Northwestern China. Science of the Total Environment 595 371-379. 10.1016/j.scitotenv.2017.03.280

Guenet, B, Gabrielle, B, Chenu, C, et al. 2021. Can $\mathrm{N}_{2} \mathrm{O}$ emissions offset the benefits from soil organic carbon storage? Global Change Biology, 27: 237-256. https://doi.org/10.1111/gcb.15342

Haagsma, W., Hoek, H., Molendijk, L. 2019. Handboek groenbemesters.

Haddaway, N. R., Hedlund, K., Jackson, L. E., Kätterer, T., Lugato, E., Thomsen, I. K., ... \& Isberg, P.E. 2017. How does tillage intensity affect soil organic carbon? A systematic review. Environmental Evidence, 6(1), 30.

Hangx SJ, Spiers CJ. Coastal spreading of olivine to control atmospheric CO2 concentrations: A critical analysis of viability. International Journal of Greenhouse Gas Control. 2009;3(6):757-67.

Hansen, EM, Munkholm, L, Olesen, JE, Melander, B. 2015. Nitrate Leaching, Yields and Carbon Sequestration after Noninversion Tillage, Catch Crops, and Straw Retention. Journal of Environmental Quality 44 (3), 868-881. 10.2134/jeq2014.11.0482

Haque, F., Santos, R. M. \& Chiang, Y. W. Optimizing Inorganic Carbon Sequestration and Crop Yield With Wollastonite Soil Amendment in a Microplot Study. Frontiers in plant science 11, 1012 (2020).

Hartmann J, Kempe S. What is the maximum potential for $\mathrm{CO}_{2}$ sequestration by "stimulated" weathering on the global scale? Naturwissenschaften. 2008;95(12):1159-64.

Hartmann J, West AJ, Renforth P, Köhler P, Christina L, Wolf-Gladrow DA, et al. 2013. Enhanced chemical weathering as a geoengineering strategy to reduce atmospheric carbon dioxide, supply nutrients, and mitigate ocean acidification. Reviews of Geophysics, 51(2):113-49.

Harty, MA, Forrestal, PJ, Watson, CJ, McGeough, KL, Carolan, R, Elliot, C, Krol, D, Laughlin, RJ, Richards, KG, Lanigan, GJ (2016) Reducing nitrous oxide emissions by changing $N$ fertiliser use from calcium ammonium nitrate (CAN) to urea based formulations. Science of the Total Environment 563-564 576-586. https://doi.org/10.1016/j.scitotenv.2016.04.120

Hauck J, Köhler P, Wolf-Gladrow D, Völker C. Iron fertilisation and century-scale effects of open ocean dissolution of olivine in a simulated $\mathrm{CO} 2$ removal experiment. Environmental Research Letters. 2016;11(2):024007.

Haughey, E., M. Suter, D. Hofer, N.J. Hoekstra, J.C. McElwain, A. Lüscher \& J.A. Finn. 2018. Higher species richness enhances yield stability in intensively managed grasslands with experimental disturbance. Scientific Reports, 8: 15047.

Heil, J, Vereecken, H, Brüggemann, N (2016) A review of chemical reactions of nitrification intermediates and their role in nitrogen cycling and nitrogen trace gas formation in soil. European Journal of Soil Science 67 (1), 23-39. doi:10.1111/ejss.12306

Hoffland, E., T.W. Kuyper, R.N.J. Comans \& R.E. Creamer, 2020. Eco-functionality of organic matter in soils. Plant and Soil, 455(1): 1-22.

Hogenkamp W. Een derde grasland te zuur http://www.boerderij.nl/Rundveehouderij/Nieuws/2013/10/Een-derde-grasland-te-zuur1399451W. Boerderij. 2013;30 oktober.

Hynes, R.K., Knowles, R. 1984. Production of nitrous oxide by Nitrosomonas europaea: effects of acetylene, $\mathrm{pH}$, and oxygen. Canadian Journal of Microbiology, 30: 1397-1404.

Iepema, G., Deru, J. G., Bloem, J., Hoekstra, N., de Goede, R., Brussaard, L., \& van Eekeren, N. (2020). Productivity and topsoil quality of young and old permanent grassland: An on-farm comparison. Sustainability, 12(7): 2600.

Iepema, G., Hoekstra, N.J., de Goede, R., Bloem, J., Brussaard, L., van Eekeren, N. 2021. Extending grassland age for climate change mitigation and adaptation on clay soils. European Journal of Soil Science: 1-14. https://doi.org/10.1111/ejss.13134.

IPCC. 2019. Ogle SM, Wakelin SJ, Buendia L, McConkey B, Baldock J, Akiyama H, Kishimoto AW, Chirinda N, Bernoux M, Bhattacharya S, Chuersuwan N, Goheer MAR, Hergoualc'h K, Ishizuka S, 
Diaz Lasco R, Pan X, Pathak H, Regina K, Sato A, Vazquez-Amabile G, Wang C, Zheng X. 2019. Chapter 5, Cropland. In: Refinement to the 2006 IPCC Guidelines for National Greenhouse Gas Inventories, 5.1 - 5.102 p. https://hdl.handle.net/10568/107139

IPCC. 2013. Climate Change 2013: The Physical Science Basis. Contribution of Working Group I to the Fifth Assessment Report of the Intergovernmental Panel on Climate Change. Cambridge University Press: Cambridge, United Kingdom and New York, NY, USA.

Jager, N, Stange, CF, Ludwig, B, Flessa, H. 2011. Emission rates of $\mathrm{N}_{2} \mathrm{O}$ and $\mathrm{CO}_{2}$ from soils with different organic matter content from three long-term fertilization experiments-a laboratory study. Biology and Fertility of Soils 47 (5), 483-494. 10.1007/s00374-011-0553-5

Jeffery, S., M.B.J. Meinders, C.R. Stoof. M. Bezemer, T.F.J. van de Voorde, L. Mommer, J. van Groenigen, 2015. Biochar application does not improve the soil hydrological function of a sandy soil. Geoderma 251-252: 47-54

Jian, J., Du, X., Reiter, M.S., Stewart, R.D. 2020. A meta-analysis of global cropland soil carbon changes due to cover cropping. Soil Biology and Biochemistry 143.

Joseph, S., A. L. Cowie, L. Van Zwieten, N. Bolan, A. Budai, W. Buss, M. L. Cayuela, E. R. Graber, J. A. Ippolito, Y. Kuzyakov, Y. Luo, Y. S. Ok, K. N. Palansooriya, J. Shepherd, S. Stephens, Z. Weng and J. Lehmann. 2021. How biochar works, and when it doesn't: A review of mechanisms controlling soil and plant responses to biochar. GCB Bioenergy 13(11): 1731-1764.

Kätterer, T., Bolinder, M.A., Andrén, O., Kirchmann, H., Menichetti, L. 2011. Roots contribute more to refractory soil organic matter than above-ground crop residues, as revealed by a long-term field experiment. Agriculture, Ecosystems \& Environment 141, 184-192.

Kelemen PB, Matter J, Streit EE, Rudge JF, Curry WB, Blusztajn J. Rates and mechanisms of mineral carbonation in peridotite: natural processes and recipes for enhanced, in situ $\mathrm{CO}_{2}$ capture and storage. Annual Review of Earth and Planetary Sciences. 2011;39:545-76.

Kell, D.B. 2011. Breeding crop plants with deep roots: Their role in sustainable carbon, nutrient and water sequestration. Annals of Botany 108, 407-418.

Kijfeed. Kijfeed diervoeders en meststoffen http://www.kijfeed.nl/prijslijst 2018.

Kim, D. G., Kirschbaum, M. U., \& Beedy, T. L. 2016. Carbon sequestration and net emissions of $\mathrm{CH}_{4}$ and $\mathrm{N}_{2} \mathrm{O}$ under agroforestry: Synthesizing available data and suggestions for future studies. Agriculture, Ecosystems \& Environment, 226, 65-78.

Köhler P, Hartmann J, Wolf-Gladrow DA. Geoengineering potential of artificially enhanced silicate weathering of olivine. Proceedings of the National Academy of Sciences. 2010;107(47):20228-33.

Kool A, Marinussen M, Blonk H. LCI data for the calculation tool Feedprint for greenhouse gas emissions of feed production and utilization. GHG Emissions of N, P and $\mathrm{K}$ fertilizer production Blonk Consultants (Ed). 2012.

Koopmans, C., Timmermans, B., de Haan, J.J., van Opheusden, M., Selin Norén, I., Slier, T., \& Wagenaar, J. P. (2020). Evaluatie van maatregelen voor het vastleggen van koolstof in minerale gronden 2019-2023: Voortgangsrapportage april 2020. Louis Bolk Instituut.

Koopmans, C., Timmermans, B., Wagenaar, J.P., van 't Hull, J., Hanegraaf, M., \& de Haan, J., 2019. Evaluatie van maatregelen voor het vastleggen van koolstof. Resultaten uit Lange Termijn Experimenten (LTE's). Louis Bolk Instituut.

Koopmans, C., van Agtmaal, M., \& van Eekeren, N. 2018. Quick scan mest en bodemkwaliteit. Louis Bolk Instituut.

Koopmans, C.J., B.G.H. Timmermans, M. Hoogmoed, D. Heupink, J.J.P. Cruijsen, J. De Haan, I. Selin Norén, T. Slier en J.P. Wagenaar. 2021. Evaluatie van maatregelen voor het vastleggen van koolstof in minerale gronden 2019-2023. Voortgangsrapportage maart 2021.

Koopmans, C.J., Bloem, J. 2018. Soil quality effects of compost and manure in arable cropping Results from using soil improvers for 17 years in the MAC trial. Louis Bolk Institute 2018-001 LbP.

Koopmans, C.J., te Grotenhuis, T., Janmaat, L. 2018. Compostgebruik op Demeterbedrijven in beeld. Louis Bolk Institute.

KWIN A. Kwantitatieve Informatie Akkerbouw en Vollegrondsgroenteteelt 2015. Publicatie; 2012.

Lebender, U, Senbayram, M, Lammel, J, Kuhlmann, H (2014) Impact of mineral N fertilizer application rates on $\mathrm{N}_{2} \mathrm{O}$ emissions from arable soils under winter wheat. Nutrient Cycling in Agroecosystems 100 (1), 111-120. 10.1007/s10705-014-9630-0

Lesschen, J.P., I. Staritsky en G.L. Velthof, 2011. Verkenning grootschalige toepassing van mineralenconcentraten in Nederland; Effecten op nutriëntenstromen en emissies. Wageningen, Alterra, Alterra-rapport 2247. 1 
Lesschen, J.P., Heesmans, H., Mol-Dijkstra, J., Van Doorn, A., Verkaik, E., Van den Wyngaert, I., Kuikman, P., 2012. Mogelijkheden voor koolstofvastlegging in de Nederlandse landbouw en natuur. Alterra rapport 2396. Alterra, Wageningen.

Lesschen, J.P., Hendriks, C.M.J., van der Linden, A., Keuskamp, J., Keuper, D., Timmermans, B., Hanegraaf, M., Conijn, S., Slier, T. 2019. Ontwikkeling praktijktool voor bodem C. Rapport 2990. Wageningen Environmental Research, Wageningen. https://doi.org/10.18174/517746.

Lesschen, J.P., Vellinga, T., van der Linden, A., Dekker, S., Schils, R.L.M., 2020. Mogelijkheden voor monitoring van $\mathrm{CO}_{2}$ vastlegging en afbraak van organische stof in de bodem op melkveebedrijven. Rapport 2993. Wageningen Environmental Research, Wageningen.

Li, CS, Frolking, S, Butterbach-Bahl, K. 2005. Carbon sequestration in arable soils is likely to increase nitrous oxide emissions, offsetting reductions in climate radiative forcing. Climatic Change 72 (3), 321-338. 10.1007/s10584-005-6791-5

Lugato, E, Leip, A, Jones, A (2018) Mitigation potential of soil carbon management overestimated by neglecting $\mathrm{N}_{2} \mathrm{O}$ emissions. Nature Climate Change 8 (3), 219. 10.1038/s41558-018-0087-z

Luske, B., M.W.P. Bestman, K. van Veluw, E. Prins MSc, P. Rombouts. 2020. Samenvatting Masterplan Agroforestry: Advies voor het realiseren van een schaalsprong van agroforestry in Nederland. Rapport 2020-018 LbD. Louis Bolk Instituut, Bunnik.

Ma, Z., Chen, H. Y., Bork, E. W., Carlyle, C. N., \& Chang, S. X. (2020). Carbon accumulation in agroforestry systems is affected by tree species diversity, age and regional climate: A global metaanalysis. Global Ecology and Biogeography, 29(10), 1817-1828.

Maeda, M, Zhao, B, Ozaki, Y, Yoneyama, T (2003) Nitrate leaching in an Andisol treated with different types of fertilizers. Environmental Pollution 121 (3), 477-487. https://doi.org/10.1016/S02697491(02)00233-6

Magdoff, F. R., \& Van Es, H.M. 2009. Building soils for better crops: Sustainable soil management. handbook series book 10. Sustainable Agric. Research and Education, Waldorf, MD.

Maillard, É. \& D. A. Angers. 2014. Animal manure application and soil organic carbon stocks: a metaanalysis. Global Change Biology, 20(2): 666-679.

Maltas, A., Kebli, H., Oberholzer, H. R., Weisskopf, P., \& Sinaj, S. 2018. The effects of organic and mineral fertilizers on carbon sequestration, soil properties, and crop yields from a long-term field experiment under a Swiss conventional farming system. Land Degradation \& Development, 29(4), 926-938.

Matsuoka, M, Kumar, A, Muddassar, M, Matsuyama, A, Yoshida, M, Zhang, KY] (2017) Discovery of Fungal Denitrification Inhibitors by Targeting Copper Nitrite Reductase from Fusarium oxysporum. Journal of Chemical Information and Modeling 57 (2), 203-213. 10.1021/acs.jcim.6b00649

McIntire $\mathrm{WH}$, Sterges AJ. Role of solvated silica in promoting migrations of fluorine, phosphorous, and calcium in 10-year rainwater drainage from slagged and wollastonited soils. Soil Science Society of America Journal. 1953;74 (3):233-47.

Mei, K, Wang, ZF, Huang, H, Zhang, C, Shang, X, Dahlgren, RA, Zhang, MH, Xia, F (2018) Stimulation of $\mathrm{N}_{2} \mathrm{O}$ emission by conservation tillage management in agricultural lands: A meta-analysis. Soil \& Tillage Research 182 86-93. 10.1016/j.still.2018.05.006

Minasny, B., B. P. Malone, A. B. McBratney, D. A. Angers, D. Arrouays, A. Chambers, V. Chaplot, Z.-S. Chen, K. Cheng, B. S. Das, D. J. Field, A. Gimona, C. B. Hedley, S. Y. Hong, B. Mandal, B. P. Marchant, M. Martin, B. G. McConkey, V. L. Mulder, S. O'Rourke, A. C. Richer-de-Forges, I. Odeh, J. Padarian, K. Paustian, G. Pan, L. Poggio, I. Savin, V. Stolbovoy, U. Stockmann, Y. Sulaeman, C.-C. Tsui, T.-G. Vågen, B. van Wesemael and L. Winowiecki. 2017. Soil carbon 4 per mille. Geoderma, 292: 59-86.

Montserrat F, Renforth P, Hartmann J, Leermakers M, Knops P, Meysman FJ. Olivine dissolution in seawater: implications for $\mathrm{CO} 2$ sequestration through enhanced weathering in coastal environments. Environmental science \& technology. 2017;51(7):3960-72.

Montserrat F, Renforth P, Hartmann J, Leermakers M, Knops P, Meysman FJR. Olivine Dissolution in Seawater: Implications for $\mathrm{CO} 2$ Sequestration through Enhanced Weathering in Coastal Environments. Environmental Science and Technology. 2017;51(7):3960-72.

Moosdorf N, Renforth P, Hartmann J. Carbon dioxide efficiency of terrestrial enhanced weathering. Environmental Science and Technology. 2014;48(9):4809-16.

Munch, JC, Velthof, GL (2007) Denitrification and Agriculture. In 'Biology of the Nitrogen Cycle. '. Ed. H Bothe, Ferguson, Stuart J., Newton, William E. 331-341. Elsevier: Amsterdam. 
Nabuurs, G.-J., Verkaik, E., 1999. De 10 meest gestelde vragen over koolstofvastlegging in bos. Nederlandse Bosbouw Tijdschrift 71: 2-5.

Necpálová, M., Li, D., Lanigan, G., Casey, I. A., Burchill, W., \& Humphreys, J. (2014). Changes in soil organic carbon in a clay loam soil following ploughing and reseeding of permanent grassland under temperate moist climatic conditions. Grass and Forage Science, 69(4), 611-624.

Nemecek T, Kägi T. Life cycle inventories of Swiss and European of agricultural production systems. Final report ecoinvent V2.0 No15a. retrieved from: www.ecoinvent.ch. Zurich and Dubendorf: Agroscope Reckenholz-Taenikon Research Station ART, Swisse Centre for Life Cycle Inventories; 2007. $15 \mathrm{p}$.

Nevens, F, Reheul, D (2003) The application of vegetable, fruit and garden waste (VFG) compost in addition to cattle slurry in a silage maize monoculture: nitrogen availability and use. European Journal of Agronomy 19 (2), 189-203. 10.1016/s1161-0301(02)00036-9

Nicholson, F, Bhogal, A, Cardenas, L, Chadwick, D, Misselbrook, T, Rollett, A, Taylor, M, Thorman, R, Williams, J (2017) Nitrogen losses to the environment following food-based digestate and compost applications to agricultural land. Environmental Pollution 228 504-516. https://doi.org/10.1016/j.envpol.2017.05.023

Norén, I. S., Keur, J., Vijn, M. P., Schoutsen, M. A., Cuperus, F., Slier, T., ... \& Schrijver, R. A. M. (2019). Klimaatcompensatie met agroforestry, wat is mogelijk?: Handreiking voor agrarisch ondernemers die bomen willen planten op hun bedrijf.

O'Brien D, Brennan P, Humphreys J, Ruane E, Shalloo L. An appraisal of carbon footprint of milk from commercial grass-based dairy farms in Ireland according to a certified life cycle assessment methodology. The International Journal of Life Cycle Assessment. 2014;19(8):1469-81.

Odlare, M, Pell, M (2009) Effect of wood fly ash and compost on nitrification and denitrification in agricultural soil. Applied Energy 86 (1), 74-80. https://doi.org/10.1016/j.apenergy.2008.04.004

Oelbermann, M., Voroney, R. P., Thevathasan, N. V., Gordon, A. M., Kass, D. C., \& Schlönvoigt, A. M. (2006). Soil carbon dynamics and residue stabilization in a Costa Rican and southern Canadian alley cropping system. Agroforestry Systems, 68(1), 27-36.

Ogle SM, Adler PR, Breidt F, Del Grosso S, Derner J, Franzluebbers A, et al. Quantifying greenhouse gas sources and sinks in cropland and grazing land systems. Quantifying greenhouse gas fluxes in agriculture and forestry: methods for entityscale inventory Office of the Chief Economist, US Department of agriculture, Washington DC Technical Bulletin. 2014(1939).

Olle, M., 2021. Review: Bokashi technology as a promising technology for crop production in Europe. Journal of Horticultural Science and Biotechnology 96, 145-152.

Olsen, JE, Askegaard, M, Bertnen, J (2004) Nitrate leaching from arable crop rotations in organic farming. In: Hatch et al (eds.) Controlling Nitrogen Flows and Losses. Wageningen Academic Publishers, Wageningen, p 389-396.

Panoutsou, C. and Labalette, F. 2007. Cereals straw for bioenergy and competitive uses. In JRC and CENER. Proceedings of the Expert Consultation Cereals Straw Resources for bioenergy in the European Union. EUR 22626 EN. JRC, Italy.

Paul, JW, Beauchamp, EG (1989) DENITRIFICATION AND FERMENTATION IN PLANT-RESIDUEAMENDED SOIL. Biology and Fertility of Soils 7 (4), 303-309.

Peichl, M., Thevathasan, N. V., Gordon, A. M., Huss, J., \& Abohassan, R.A. 2006. Carbon sequestration potentials in temperate tree-based intercropping systems, southern Ontario, Canada. Agroforestry systems, 66(3), 243-257.

Poeplau, C., Don, A. 2015. Carbon sequestration in agricultural soils via cultivation of cover crops - A meta-analysis. Agriculture, Ecosystems \& Environment 200, 33-41.

Poirier, V., Roumet, C., Munson, A.D. (2018) The root of the matter: Linking root traits and soil organic matter stabilization processes. Soil Biology and Biochemistry 120, 246-259.

Poulton, P., J. Johnston, A. Macdonald, R. White and D. Powlson. 2018. Major limitations to achieving "4 per 1000" increases in soil organic carbon stock in temperate regions: Evidence from long-term experiments at Rothamsted Research, United Kingdom. Global Change Biology, 24(6): 2563-2584.

Powlson, D.S., Glendining, M.J., Coleman, K., Whitmore, A.P., 2011. Implications for Soil Properties of Removing Cereal Straw: Results from Long-Term Studies. Agronomy Journal, 103: 279-287.

Quiroz, M., Céspedes, C., 2019. Bokashi as an Amendment and Source of Nitrogen in Sustainable Agricultural Systems: a Review. Journal of Soil Science and Plant Nutrition 19, 237-248.

Rasse, D.P., Rumpel, C., Dignac, M.-F. (2005) Is soil carbon mostly root carbon? Mechanisms for a specific stabilisation. Plant and Soil 269, 341-356. 
Ravishankara, AR, Daniel, JS, Portmann, RW (2009) Nitrous Oxide $\left(\mathrm{N}_{2} \mathrm{O}\right)$ : The Dominant OzoneDepleting Substance Emitted in the 21st Century. Science 326 (5949), 123.

Rietberg P., Luske B., Visser A., Kuikman P. 2013. Handleiding goed koolstofbeheer. Louis Bolk Instituut 2013-002 LbP.

Rietra R, Hoogesteger B, Bergsma H. 2011. Olivijn, de groene klimaatridder. Milieu Dossier, 5: 28-30.

Rietra R, van Beusekom M, Bergsma H. 2012. Herwaardering van een vergeten bodemverbeteraar: steenmeel voor bodemvruchtbaarheid en klimaatdoelstellingen landbouw. Bodem, 22(4): 34-6.

Romkens, P.F.A.M., Rietra, R.P.J.J., Spijker, J.H., 2020. Aanzet kennisprogramma circulair terreinbeheer; Landbouwkundig relevante eigenschappen van maaisel, bokashi en compost. Wageningen Environmental Research Rapport 3006, 46.

Ruyssenaars, P.G., P.W.H.G. Coenen, J.D. Rienstra, P.J. Zijlema, E.J.M.M. Arets, K. Baas, R. Dröge, G. Geilenkirchen, M. 't Hoen, E. Honig, B. van Huet, E.P. van Huis, W.W.R. Koch, L.A. Lagerwerf, R.M. te Molder, J.A. Montfoort, J. Vonk, M.C. van Zanten. 2020. Greenhouse gas emissions in the Netherlands 1990-2018 National Inventory Report 2020, RIVM report 2020-0031.

Sánchez-Monedero, M. A., M. L. Cayuela, M. Sánchez-García, B. Vandecasteele, T. D’Hose, G. López, C. Martínez-Gaitán, P. J. Kuikman, T. Sinicco and C. Mondini. 2019. Agronomic Evaluation of Biochar, Compost and Biochar-Blended Compost across Different Cropping Systems: Perspective from the European Project FERTIPLUS. Agronomy 9(5): 225.

Schoeneberger, M., Bentrup, G., De Gooijer, H., Soolanayakanahally, R., Sauer, T., Brandle, J., ... \& Current, D. 2012. Branching out: Agroforestry as a climate change mitigation and adaptation tool for agriculture. Journal of Soil and Water Conservation, 67(5), 128A-136A.

Schuiling R, Krijgsman P. 2006. Enhanced weathering: an effective and cheap tool to sequester $\mathrm{CO}_{2}$. Climatic Change. 74(1-3): 349-54.

Schulp, C.J.E. \& P.H. Verburg. 2009. Effect of land use history and site factors on spatial variation of soil organic carbon across a physiographic region. Agriculture, Ecosystems \& Environment, 133(1-2): 86-97.

Seifritz W. $\mathrm{CO}_{2}$ disposal by means of silicates. Nature. 1990;345:486.

Selin Norén, I., van Geel, W., de Haan, J. 2021. Cover crop reference values: effective organic matter and nitrogen uptake, Wageningen Research, Report WPR 877.

Smit, B. \& J Jager. 2018. Schets van de akkerbouw in Nederland: structuur-, landschaps- en milieukenmerken die een relatie hebben tot biodiversiteit. https://edepot.wur.nl/463816

Smith, KA, Dobbie, KE, Thorman, R, Watson, CJ, Chadwick, DR, Yamulki, S, Ball, BC (2012) The effect of $\mathrm{N}$ fertilizer forms on nitrous oxide emissions from UK arable land and grassland. Nutrient Cycling in Agroecosystems 93 (2), 127-149. 10.1007/s10705-012-9505-1

Smith, P., Smith, J.U., Powlson, D.S., McGill, W.B., Arah, J.R.M., Chertov, O.G., Coleman, K., Franko, U. et al. 1997. A comparison of the performance of nine soil organic matter models using datasets from seven long-term experiments. Geoderma, 81, S. 153-225.

Smolders E, Oorts K, Van Sprang P, Schoeters I, Janssen CR, McGrath SP, et al. 2009. Toxicity of trace metals in soil as affected by soil type and aging after contamination: using calibrated bioavailability models to set ecological soil standards. Environmental Toxicology and Chemistry, 28(8): 1633-42.

Soussana, J.-F., S. Lutfalla, F. Ehrhardt, T. Rosenstock, C. Lamanna, P. Havlík, M. Richards, E. Wollenberg, J.-L. Chotte, E. Torquebiau, P. Ciais, P. Smith and R. Lal. 2019. Matching policy and science: Rationale for the ' 4 per 1000 - soils for food security and climate' initiative. Soil and Tillage Research, 188: 3-15.

Staps, S., Rietberg, P., Luski, B. Visser, A., Kuikman, P. 2017. Handleiding goed koolstofbeheer Concept levend document, Update van de versie van 2013. Louis Bolk Instituut.

Stevens, JR, Laughlin, R.J. 2001. Effect of liquid manure on the mole fraction of nitrous oxide evolved from soil containing nitrate. Chemosphere 42 (2), 105-111. https://doi.org/10.1016/S00456535(00)00115-6

Taghizadeh-Toosi, A., Christensen, B.T., Hutchings, N.J., Vejlin, J., Kätterer, T., Glendining, M., Olesen, J.E., 2014. C-TOOL: A simple model for simulating whole-profile carbon storage in temperate agricultural soils. Ecological Modelling, 292: 11-25.

Thapa, R., Mirsky, S.B., Tully, K.L. 2018. Cover crops reduce nitrate leaching in agroecosystems: A global meta-analysis. Journal of Environmental Quality 47, 1400-1411. 
Thorup-Kristensen, K. 2001. Are differences in root growth of nitrogen catch crops important for their ability to reduce soil nitrate-N content, and how can this be measured? Plant and Soil 230, 185-195.

Thorup-Kristensen, K., Halberg, N., Nicolaisen, M., Olesen, J.E., Crews, T.E., Hinsinger, P., Kirkegaard, J., Pierret, A., Dresbøll, D.B. (2020) Digging Deeper for Agricultural Resources, the Value of Deep Rooting. Trends in Plant Science 25, 406-417.

van Balen D, Topper C, van Geel W, van den Berg W, de Haas M, Bussink W, et al. Effecten bodem- en structuurverbeteraars. Praktijkonderzoek Plant \& Omgeving, onderdeel van Wageningen UR, Business Unit Akkerbouw, Groene Ruimte en Vollegrondsgroenten, 2016.

van Bruggen, C., \& Gosseling, M. 2020. Dierlijke mest en mineralen 2019. Den Haag / Heerlen Centraal Bureau voor de Statistiek.

van der Wal, A., Hennen, W. \& de Koeijer, T. 2019. Bodem- en waterkwaliteit in de Nederlandse landbouw - Relatie tussen bodemorganische stof en nitraatuitspoeling op melkveebedrijven op zandgrond. Bodem, 2019(5): 34-36.

van Eekeren N, Smeulders G, Carpay B, Bergsma H. 2014. Kali uit gesteentemeel voor grasklaver. V-focus. 2014, juni: 38-9.

van Eekeren, N., de Boer, H., Bloem, J., Schouten, T., Rutgers, M., de Goede, R., \& Brussaard, L. 2009. Soil biological quality of grassland fertilized with adjusted cattle manure slurries in comparison with organic and inorganic fertilizers. Biology and Fertility of Soils, 45(6), 595-608.

van Eekeren, N., Deru, J., de Boer, H., Philipsen, B. 2011. Terug naar de graswortel. Een betere nutrientenbenutting door een intensievere en diepere beworteling. Louis Bolk Instituut.

van Eekeren, N., Deru, J., Hoekstra, N. en de Wit, J. 2018. Carbon Valley - Organische stofmanagement op melkveebedrijven. Louis Bolk Instituut.

van Eekeren, N., Iepema, G., \& Domhof, B. 2016. Goud van Oud Grasland: Bodemkwaliteit onder jong en oud grasland op klei. Louis Bolk Instituut.

van Groenigen, J., Zwart, K. 2007. Koolstof en stikstof mineralisatie van verschillende soorten compost in de bodem. Wageningen: Alterra.

van Ruijven J., Berendse F. 2003. Positive effects of plant species diversity on productivity in the absence of legumes. Ecology letters, 6(3): 170-175.

van Ruijven J., Berendse F. 2005. Diversity-productivity relationships: Initial effects, long-term patterns, and underlying mechanisms. Proceedings of the National Academy of Sciences of the United States of America, 102: 695-700.

van Schooten H, Philipsen B, Groten J. 2016. Handboek snijmaïs. Wageningen Livestock Research.

Velthof, G.L. 2003. Relaties tussen mineralisatie, denitrificatie en indicatoren voor bodemkwaliteit in landbouwgronden. Alterra, Research Instituut voor de Groene Ruimte: Wageningen.

Velthof, G.L., Oenema, O., Postma, R., Van Beusichem, M.L. 1996. Effects of type and amount of applied nitrogen fertilizer on nitrous oxide fluxes from intensively managed grassland. Nutrient Cycling in Agroecosystems 46 (3), 257-267. 10.1007/bf00420561

Velthof, GL, Kuikman, PJ, Oenema, O. 2002. Nitrous oxide emission from soils amended with crop residues. Nutrient Cycling in Agroecosystems 62 (3), 249-261. 10.1023/a:1021259107244

Velthof, G.L., Mosquera, J. 2011. The impact of slurry application technique on nitrous oxide emission from agricultural soils. Agriculture Ecosystems \& Environment 140 (1-2), 298-308. 10.1016/j.agee.2010.12.017

Velthof, G.L., van Bruggen, C., Arets, E., Groenestein, C.M., Helming, J.F.M., Luesink, H.H., Schelhaas, M.J., Huijsmans, J.F.M., 2019. Referentieraming van emissies naar de lucht uit landbouw en landgebruik tot 2030: Achtergronddocument bij de Klimaat- en Energieverkenning 2019, met ramingen van emissies van methaan, lachgas, ammoniak, stikstofoxide, fijnstof en NMVOS uit de landbouw en kooldioxide en lachgas door landgebruik. Wageningen, Wageningen Environmental Research, Rapport 2970.

Vesterdal, L., Rosenqvist, L., Van Der Salm, C., Hansen, K., Groenenberg, B. J., \& Johansson, M. B. (2007). Carbon sequestration in soil and biomass following afforestation: experiences from oak and Norway spruce chronosequences in Denmark, Sweden and the Netherlands. In Environmental Effects of Afforestation in North-Western Europe (pp. 19-51). Springer, Dordrecht.

Vonk, J, Sluis, SMvd, Bannink, A, Bruggen, Cv, Groenestein, CM, Huijsmans, JFM, Kolk, JWHvd, Lagerwerf, LA, Luesink, HH, Oude Voshaar, SV, Velthof, GL. 2018. Methodology for estimating emissions from agriculture in the Netherlands - update 2018: calculations of $\mathrm{CH}_{4}, \mathrm{NH} 3, \mathrm{~N}_{2} \mathrm{O}, \mathrm{NOx}$, 
PM10, PM2.5 and $\mathrm{CO}_{2}$ with the National Emission Model for Agriculture (NEMA). Statutory Research Tasks Unit for Nature \& the Environment: Wageningen.

Wenum, J., de Haan, J., van Geel, W., van Dijk, W., van Valen, A., Postma, R., Brinks, H., Brolsma, K., Heestermans, S., Mager, A., de Jongh, E. 2013. Handboekbodembemesting.

West TO, Marland G. 2002. A synthesis of carbon sequestration, carbon emissions, and net carbon flux in agriculture: comparing tillage practices in the United States. Agriculture, Ecosystems \& Environment, 91(1-3): 217-32.

West TO, McBride AC. The contribution of agricultural lime to carbon dioxide emissions in the United States: dissolution, transport, and net emissions. Agriculture, Ecosystems \& Environment. 2005; 108(2):145-54.

Whalen, J.K., Benslim, H., Jiao, Y., Sey, B.K. (2008) Soil organic carbon and nitrogen pools as affected by compost applications to a sandy-loam soil in Quebec. Canadian Journal of Soil Science 88, 443-450.

Whitehead, D. 2020. Management of Grazed Landscapes to Increase Soil Carbon Stocks in Temperate, Dryland Grasslands. Frontiers in Sustainable Food Systems 4.

Wiersma P., Luske B., Bos J., Hakkert J., Ottens H.J., Postma M., Klaassen R., Timmermans B., Zanen M., 2019, Vogelakkers: het effect op de biodiversiteit en de landbouwkundige inpasbaarheid. Grauwe Kiekendief - Kenniscentrum Akkervogels, Louis Bolk Instituut, Vogelbescherming.

Wijsman J. Land- en tuinbouwcijfers. 2012. LEI, onderdeel van Wageningen UR/CBS, 2012.

Wit, J. de, N.J.M. van Eekeren, W. Honkoop, J. Pijlman MSc. 2020. De waarde van vaste mest: Quick scan mest en natuur in de Krimpenerwaard. Rapport 2020-020 LbD. Louis Bolk Instituut, Bunnik.

Wrage, N, Velthof, GL, van Beusichem, ML, Oenema, O (2001) Role of nitrifier denitrification in the production of nitrous oxide. Soil Biology \& Biochemistry, 33(12-13): 1723-1732. 10.1016/s00380717(01)00096-7

Wrage-Monnig, N, Horn, MA, Well, R, Muller, C, Velthof, G, Oenema, O (2018) The role of nitrifier denitrification in the production of nitrous oxide revisited. Soil Biology \& Biochemistry, 123: A3A16. 10.1016/j.soilbio.2018.03.020

Wuebbles, D.J. 2009. Nitrous Oxide: No Laughing Matter. Science 326 (5949), 56-57. $10.1126 /$ science. 1179571

Xia, L, Lam, SK, Wolf, B, Kiese, R, Chen, D, Butterbach-Bahl, K (2018) Trade-offs between soil carbon sequestration and reactive nitrogen losses under straw return in global agroecosystems. Global Change Biology 0 (0), 10.1111/gcb.14466

Xu S., Eisenhauer N., Ferlian O., Zhang J., Zhou G., Lu X., Liu C. and Zhang D. 2020. Species richness promotes ecosystem carbon storage: evidence from biodiversity-ecosystem functioning experiments Proc. R. Soc. B., 28720202063.

Zhou, MH, Zhu, B, Wang, SJ, Zhu, XY, Vereecken, H, Bruggemann, N (2017) Stimulation of $\mathrm{N}_{2} \mathrm{O}$ emission by manure application to agricultural soils may largely offset carbon benefits: a global meta-analysis. Global Change Biology 23 (10), 4068-4083. 10.1111/gcb.13648

Zhu-Barker, X, Doane, TA, Horwath, W.R. 2015. Role of green waste compost in the production of $\mathrm{N}_{2} \mathrm{O}$ from agricultural soils. Soil Biology and Biochemistry, 83: 57-65.

https://doi.org/10.1016/j.soilbio.2015.01.008 


\section{Bijlage 1 Referenties figuur niet-kerende grondbewerking}

\begin{tabular}{|c|c|c|c|c|c|}
\hline $\begin{array}{l}\text { Diepte } \\
\text { (m) }\end{array}$ & Referentie & Locatie & $\begin{array}{l}\text { Effect (ton } \\
\mathrm{CO}_{2} / \mathrm{ha} / \mathrm{jaar} \text { ) }\end{array}$ & Sign. Niveau & Bodemtype \\
\hline $0-5 \mathrm{~cm}$ & Sun et al., 2011 & Schotland & 2.13 & $*$ & Zand \\
\hline $0-5 \mathrm{~cm}$ & Meurer et al., 2018 & Boreo-gematigde regio & 0.32 & $*$ & - \\
\hline $0-10 \mathrm{~cm}$ & Crittenden et al., 2015 & Nederland & 2.21 & $*$ & Klei \\
\hline $0-10 \mathrm{~cm}$ & Sun et al., 2011 & Schotland & 4.18 & $*$ & Zand \\
\hline $0-10 \mathrm{~cm}$ & Meurer et al., 2018 & Boreo-gematigde regio & 0.57 & $*$ & - \\
\hline $0-20 \mathrm{~cm}$ & Crittenden et al., 2015 & Nederland & 0.81 & $*$ & Klei \\
\hline $0-20 \mathrm{~cm}$ & Sun et al., 2011 & Schotland & 4.99 & $*$ & Zand \\
\hline $0-20 \mathrm{~cm}$ & Deru et al., 2015 & Lelystad & 1.03 & $*$ & Klei \\
\hline $0-20 \mathrm{~cm}$ & Deru et al., 2015 & Rolde & 1.38 & & Zand \\
\hline $0-20 \mathrm{~cm}$ & Meurer et al., 2018 & Boreo-gematigde regio & 0.81 & $*$ & - \\
\hline $0-30 \mathrm{~cm}$ & Sun et al., 2011 & Schotland & 4.91 & $*$ & Zand \\
\hline $0-30 \mathrm{~cm}$ & Deru et al., 2015 & Lelystad & -0.17 & & Klei \\
\hline $0-30 \mathrm{~cm}$ & Deru et al., 2015 & Rolde & 1.03 & & Zand \\
\hline $0-30 \mathrm{~cm}$ & Haddaway et al., 2017 & Boreo-gematigde regio & 0.33 & & - \\
\hline $0-30 \mathrm{~cm}$ & Meurer et al., 2018 & Boreo-gematigde regio & 0.77 & $*$ & - \\
\hline $0-30 \mathrm{~cm}$ & Koopmans et al., 2019 & Lelystad & -0.40 & & Klei \\
\hline $0-30 \mathrm{~cm}$ & Koopmans et al., 2019 & Drenthe, Veenkoloniën & 4.33 & & Zand \\
\hline $0-30 \mathrm{~cm}$ & Koopmans et al., 2019 & Limburg & -5.76 & & Zand \\
\hline $0-30 \mathrm{~cm}$ & Koopmans et al., 2020 & Lelystad & 0.69 & & Klei \\
\hline $0-30 \mathrm{~cm}$ & Koopmans et al., 2020 & België & 0.12 & & Klei \\
\hline $0-30 \mathrm{~cm}$ & Koopmans et al., 2020 & Limburg & -5.82 & & Zand \\
\hline $0-30 \mathrm{~cm}$ & Koopmans et al., 2020 & Limburg & 4.28 & & Zand \\
\hline $0-30 \mathrm{~cm}$ & Koopmans et al., 2020 & Limburg & -2.79 & & Zand \\
\hline $0-30 \mathrm{~cm}$ & Koopmans et al., 2020 & Limburg & -0.66 & & Zand \\
\hline $0-40 \mathrm{~cm}$ & Sun et al., 2011 & Schotland & 2.49 & & Zand \\
\hline $0-60 \mathrm{~cm}$ & Sun et al., 2011 & Schotland & 6.89 & & Zand \\
\hline $0-60 \mathrm{~cm}$ & Koopmans et al., 2020 & Lelystad & -0.43 & & Klei \\
\hline $0-60 \mathrm{~cm}$ & Koopmans et al., 2020 & België & -2.44 & $*$ & Klei \\
\hline $0-60 \mathrm{~cm}$ & Koopmans et al., 2020 & Limburg & -3.74 & & Zand \\
\hline $0-60 \mathrm{~cm}$ & Koopmans et al., 2020 & Limburg & -1.55 & & Zand \\
\hline $0-60 \mathrm{~cm}$ & Koopmans et al., 2020 & Limburg & -7.75 & & Zand \\
\hline $0-60 \mathrm{~cm}$ & Koopmans et al., 2020 & Limburg & -2.65 & & Zand \\
\hline $0-150 \mathrm{~cm}$ & Haddaway et al., 2017 & Boreo-gematigde regio & 0.36 & & - \\
\hline
\end{tabular}




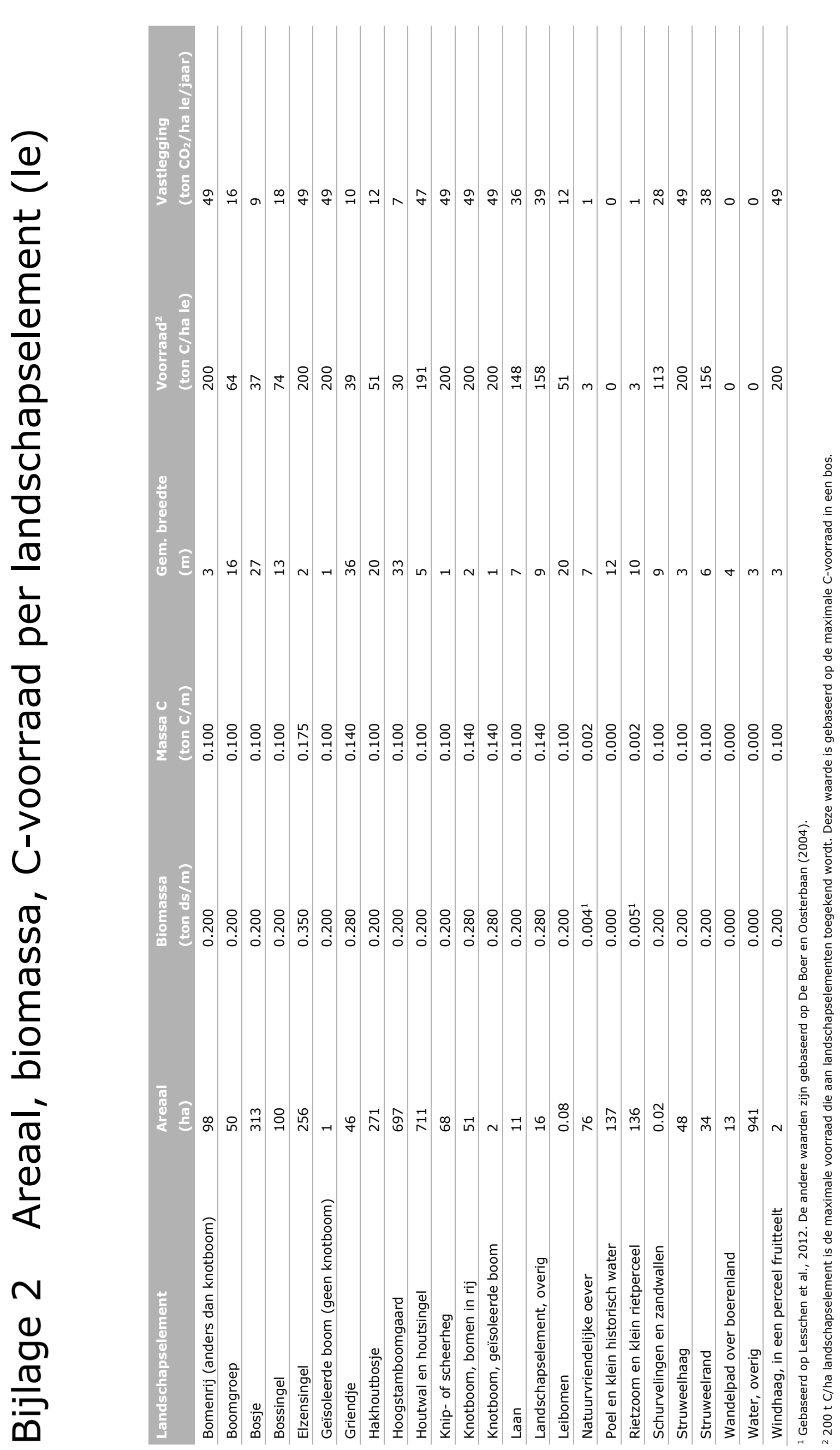


Wageningen Environmental Research Postbus 47

6700 AA Wageningen

T 0317480700

www.wur.nl/environmental-research

Wageningen Environmental Research

Rapport 3130

ISSN 1566-7197
De missie van Wageningen University \& Research is 'To explore the potential of nature to improve the quality of life'. Binnen Wageningen University \& Research bundelen Wageningen University en gespecialiseerde onderzoeksinstituten van Stichting Wageningen Research hun krachten om bij te dragen aan de oplossing van belangrijke vragen in het domein van gezonde voeding en leefomgeving. Met ongeveer 30 vestigingen, 6.800 medewerkers ( $6.000 \mathrm{fte}$ ) en 12.900 studenten behoort Wageningen University \& Research wereldwijd tot de aansprekende kennisinstellingen binnen haar domein. De integrale benadering van de vraagstukken en de samenwerking tussen verschillende disciplines vormen het hart van de unieke Wageningen aanpak. 


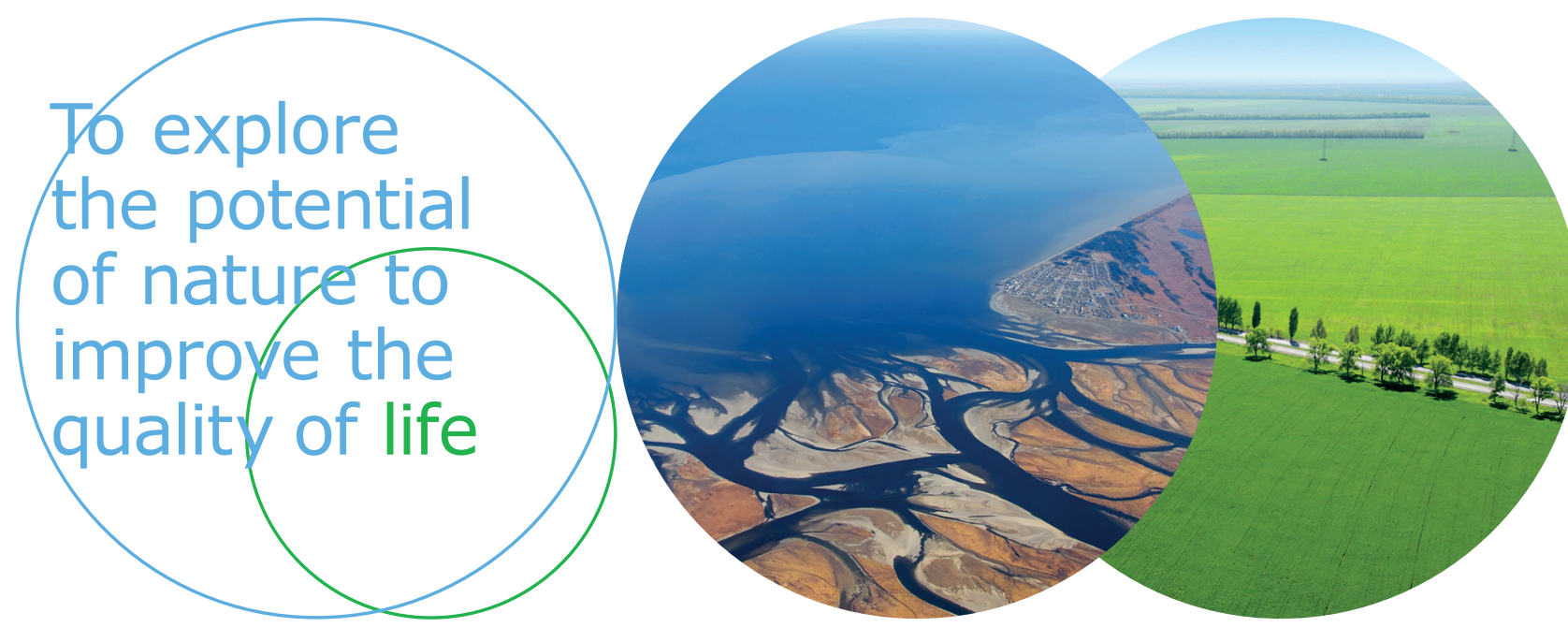

Wageningen Environmental Research Postbus 47

$6700 \mathrm{AB}$ Wageningen

T 317480700

www.wur.nl/environmental-research

Rapport 3130

ISSN 1566-7197
De missie van Wageningen University \& Research is 'To explore the potential of nature to improve the quality of life'. Binnen Wageningen University \& Research bundelen Wageningen University en gespecialiseerde onderzoeksinstituten van Stichting Wageningen Research hun krachten om bij te dragen aan de oplossing van belangrijke vragen in het domein van gezonde voeding en leefomgeving. Met ongeveer 30 vestigingen, 6.800 medewerkers (6.000 fte) en 12.900 studenten behoort Wageningen University \& Research wereldwijd tot de aansprekende kennisinstellingen binnen haar domein. De integrale benadering van de vraagstukken en de samenwerking tussen verschillende disciplines vormen het hart van de unieke Wageningen aanpak. 